\title{
Commercial Nuclear Power 1990
}

\section{Prospects for the United States and the World}

\section{Energy Information Administration}

Office of Coal, Nuclear, Electric and Alternate Fuels

U.S. Department of Energy

Washington, DC 20585 


\section{Data Contacts}

This report was prepared in the Office of Coal, Nuclear, Electric and Alternate Fuels by the Nuclear and Alternate Fuels Division. Questions regarding the contents of the report should be addressed to Howard Walton (202/254-5500), Director, Nuciear and Alternate Fuels Division; Betsy O'Brien (202/254-5506), Chief of the Data Analysis and Forecasting Branch; or Mark Gielecki (202/254-5509), project manager.
Detailed technical questions concerning specific subject areas discussed in the report may be referred to the following individuals: Roger Diedrich (202/254-5489), domestic nuclear power; James Hewlett (202/254-55()7), current nuclear power issties; and Kenneth C. Wade (202/254-5514) or S. Victoria Krusiewski (202/254-5538), forcign nuclear power. 


\section{Preface}

This analysis report presents the current stat us and outlook for commercial nuclear generating units for all countries in the world with free market economies (FME). Information regarding operable reactors in countries with transitional and centrally planned economies is also presented. The No New (Orders case of this report documents the U.S. nuclear capacity and generation projections through 2010 for all cases presented in the Energy Information Administration report Annual Energy Ottlook 1990. Long-term projections of U.S. nuclear capacity and generation for three different scenarios through the year 2030 are provided in suppost of the Department of Energy's activities pertaining to the Nuclear Waste Policy Act of 1982 (as amended in 1987), and are used to produce the projections of fuel cyclo requirements and spent fuel discharges contained in World Nuclear Fuel Cycle Requirements 1990). These projections also support the Energy Information Administration's annual report, Domestic Uranium Mining and Milling Industry: Viability Assessment, and are provided to the Organization for Economic Cooperation and Development (OECD) for preparation of the NEA/OECD report, Summary of Nuclear Power and Fuel Cycle Data in OECD Member Countries.

The World Integrated Nuclear Evaluation System (WINES) model, used for calculating the long-term nuclear capacity projections in this report, is documented in Model Documentation of the World Integrated
Nuclear Evaluation System, Volumes I, II, and III (E.H Pechan and Associates, December 1984). The International Nuclear Mode! (INM), used for calculating the generation values in this report, is documented in $l n$ ternational Nuclear Model, Volumes I, II, and III, prepared by System Sciences, Inc. (Bethesda Maryland). Information on obtaining the documentation and a computer lape containing all the programs, data input files for this report, and instructions for use of the models, allowing users to reproduce the results of the study, are available from the National Energy Information Center, Room 1F-048, Forrestal Building, Washington, DC 20585 (202/586-8800).

This year the report (Appendix J) contains, for the first time, information on nuclear plant construction costs as reported on the Form EIA-254, Previously, this information was contained in Energy Information Administration annual reports, the most recent of which was, Nuclear Power Plant Construction Activity 1988, DOE/EIA-0473 (Washington, DC, June 1989).

Since a model cannot fully address the complexities of the real world, this report does not provide unqualified predictions of the future. The projections presented in this report represent expectations of what could occur under a given set of assumptions. If conditions change, the projections will be affected accordingly. The uncertainty inherent in the projections should be recognized, so that they can be used in the proper context. 


\section{Contents}

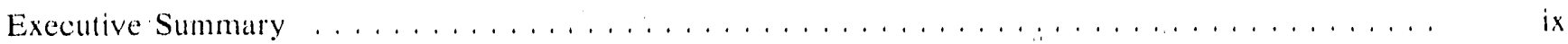

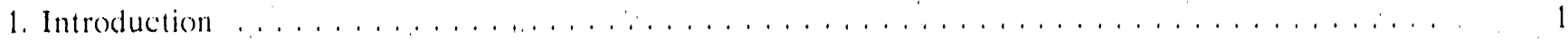

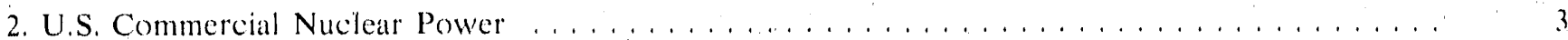

Status as of December $31,1989, \ldots \ldots \ldots \ldots \ldots \ldots$

Outlook for the Intermediate Term, Through $2010 \ldots \ldots \ldots \ldots$

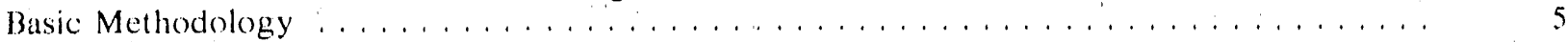

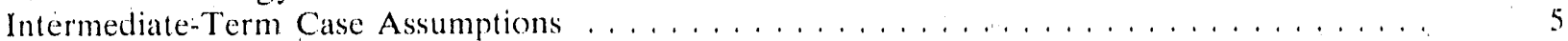

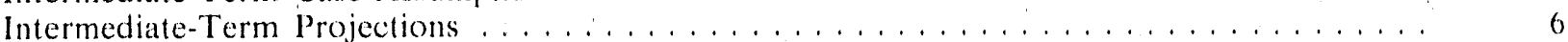

Prospects for the Long Term, Through $2030 \ldots \ldots \ldots \ldots \ldots$

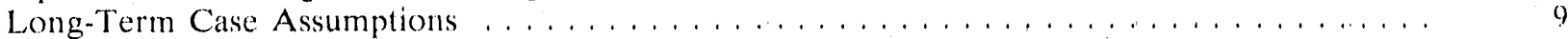

Long-Term Projections of Installed Nuclear Capacity and Generation . . . . . . . . . . . 12

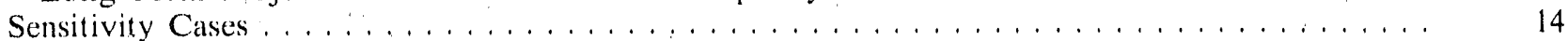

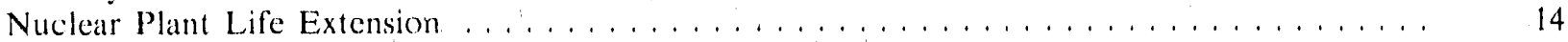

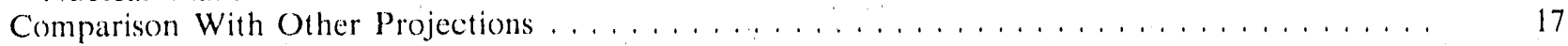

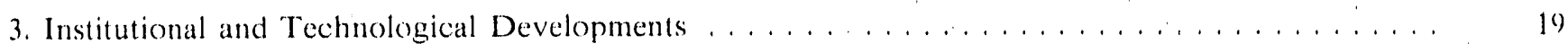

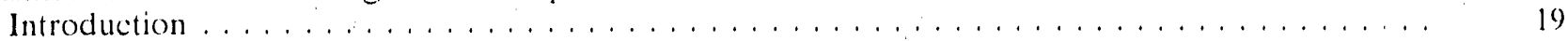

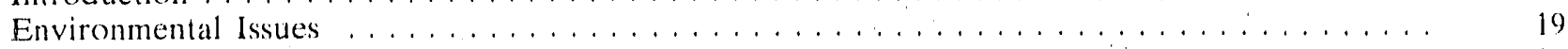

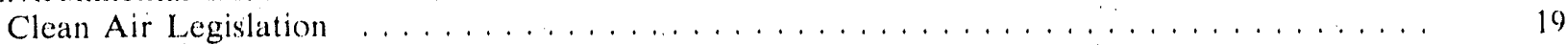

Global Climate Change and the Future of Nuclear Power . . . . . . . . . . . . . . .

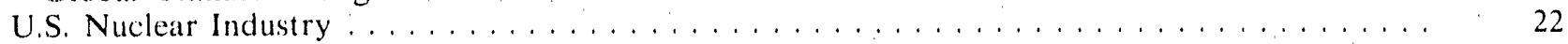

U.S. Nuclear Technology Review . . . . . . . . . . . . . . . . . . . . . . . . 22

Nuclear Power Plant Decommissioning: Cost Estimates and Estimating Methodologies . . . . . 24

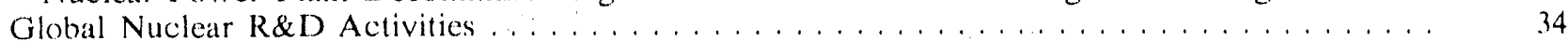

Commercial Cooperation in the Private Sector $\ldots \ldots \ldots \ldots \ldots \ldots$

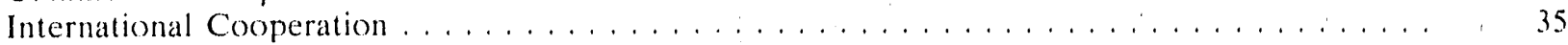

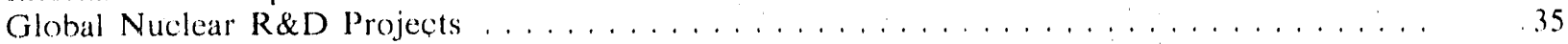

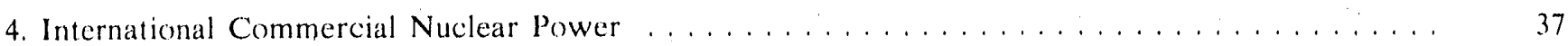

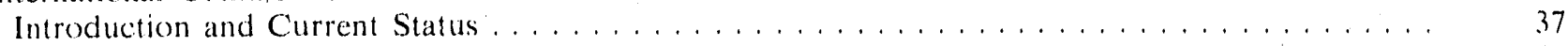

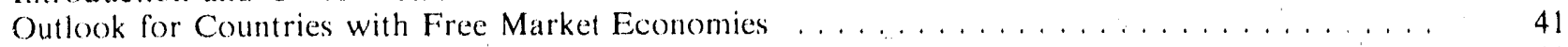

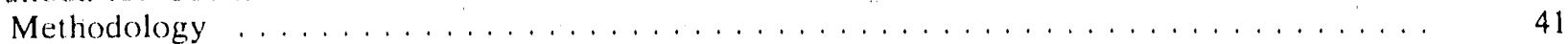

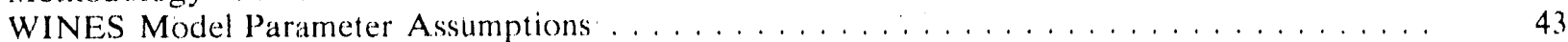

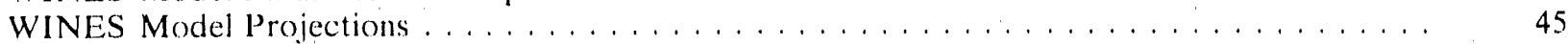

Comparison With Projections From Previous Years $\ldots \ldots \ldots \ldots \ldots$

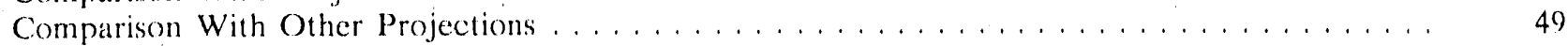

5. Review of Foreign Nuclear Power Programs . . . . . . . . . . . . . . . . . . . . . . 51

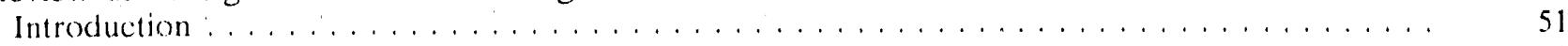

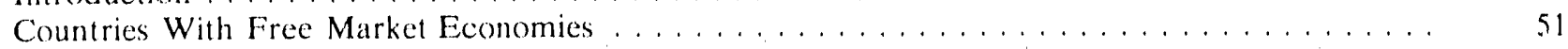

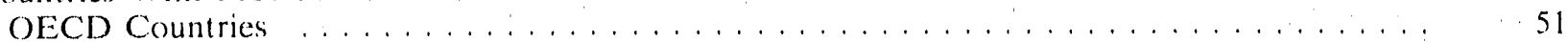

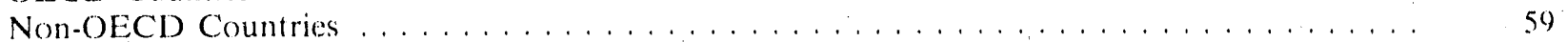

Countries With Potential or Inactive Nuclear Power Programs . . . . . . . . . . . . . 64

Countries With Regulated Market Economies (RME) . . . . . . . . . . . . . . . . . . . . . . 65

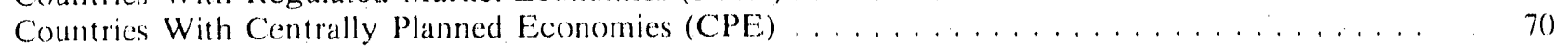

Appendices

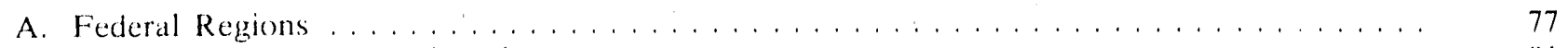

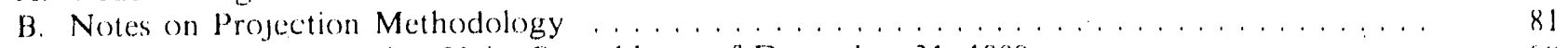

C. U,S. Nuclear Generating Units Operable as of December 31, $1989 \ldots \ldots$. . . . . . . . . . .

D. U.S. Nuclear Generating Units in the Construction Pipeline as of Decernber 31, 1989, . . . 97 
E. Nuclear Ciencrating Unit Reactors Ordered in the United States, 1953-1989 ...........

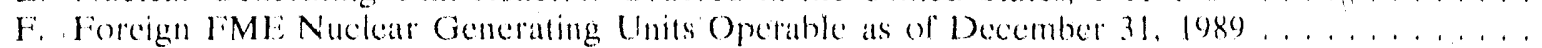

G. Foreign FME Nuclear Generating Units in the Construction Pipeline ats of December 31. 1989

H. Foreign Nuclear Generating Units Operable as of Decomber 31, 1989 in Countries with

Regulated Matket and Centrally Panned Economies . . . . . . . . . . . . . . . . . . .

1. Anmual Capacity and Generation Projections for U.S. Nuclear Power Supply Sicenarios.....

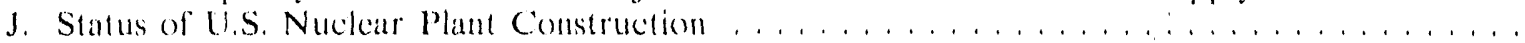

\section{Tables}

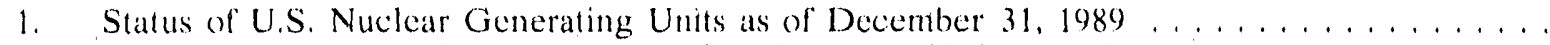

U.S. Nuclear Generating Units Achieving the Best L.ifetime Performance Records ......

3. U.S. Operable Nuclear Capacity at the End of the Year, 1989, and Projections for 1990

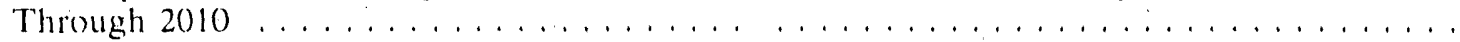

4. U.S. Operable Nuclear Capacity by Federal Region, 1989, and Projections for 2000 and

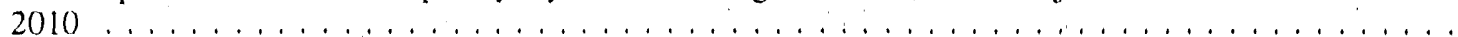

5.

6.

7.

8.

c)

10.

11.

12.

13.

14.

15.

16.

17.

18.

19.

20 .

21.

22.

23.

24.

25.

26.

27.

28.

29.

30

B1.

U.S. Nuclear Generation in 1989, and Projections for 2000) and 2010 . . . . . . . . . .

Assumed Parameter Values of the WINES Model for the United States, 2010-2030 . . . . . .

EIA/WINES Model Results for U.S. Economic and Energy Growth Rates, 2010)-2030 . . .

U.S. Operable Nuclear Capacity and Generation at the End of the Year, 1989, and

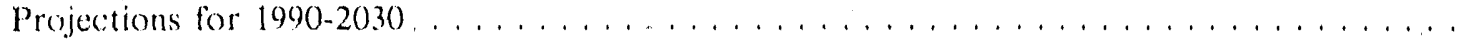

Nuclear Capacity Build Rate Implied by Projections . . . . . . . . . . . . . . . . . . . . . U.S. Operable Nuclear Capacity Assuming 70 Percent Plant Life Extension 1990-2030 . . . . Comparison of Projections for U.S. Nuclear Capacity at the End of the Year, 1990-2020 . . Summary of Reevaluated Decommissioning Costs for Light-Water Reactors . . . . . . . . . . Summary of the Estimated Cost for Immed te Dismantlement of a Reference PWR and

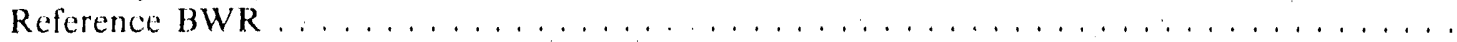
Comparison of TLG Site-Specific Estimat i to NRC's Cost Estimates . . . . . . . . . . . . PNL Comparison of Staff Labor Estimatcd Without Demolition at Reference BWR . . . . . PWR: Adjustment of Estimated Costs for Immediate Dismantlement to 1984 Cost Base .... BWR: Adjustment of Estimated Costs for Immediate Dismantlement to 1984 Cost Base ... . PWR: Adjustment of Estimated Costs for Preparations for Safe Storage to 1984 Cost Base BIVR: Adjustment of Estimated Costs for Preparations for Safe Storage to 1984 Cost Base . FME Operable Nuclear Power Plant Statistics, 1987 and $1989 \ldots \ldots \ldots \ldots \ldots$ FME Operable Nuclear Capacily Status, 1989

Status of Foreign FME Commercial Nuclear Generating Units in the Construction Pipeline as of December 31, 1989 .

Nuclear Capacity and Generation in Countries with Regulated Market and Centrally

Planned Economies, as of December 31, 1989

1985, 1989 FME Operable Nuclear Capacities and Projected Capacities for 1995,2000 , and

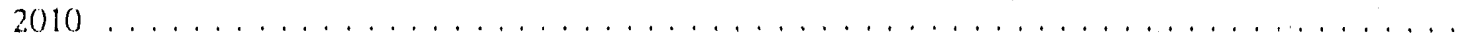

Economic Parameter Values Assumed in the WINES Model for Country Groups . . . . . . . Energy Parameter Values Assumed in the WINES Model for Country Groups . . . . . . . . Capacity Factors for Commercial Nuclear Power Plants in FME Countries . . . . . . . . . . . EIA/WINES Model Lower Reference Case Economic and Energy Growth Rates, for FME Countries, 1985-2010

Operable Nuclear Capacities, $1988-1989$, and Lower Reference Case Projections for Sclected

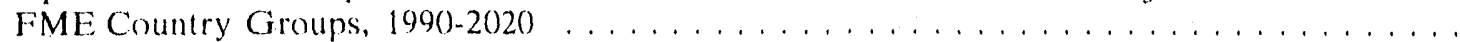
Comparison of Projections of FME Nuclear Capacity at the End of the Year, 1995, 2000, and 2010

Average Estimated Times Between Milestones for 38 Nuclear Units in the Construction

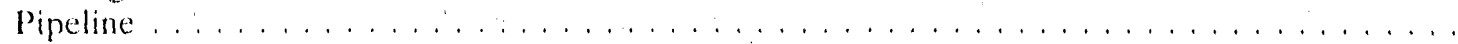

C1. Roster of U.S. Nuclear Cienerating Units Operable as of December 31, 1989, by Federal

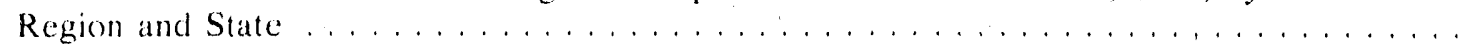

D) Roster of U.S. Nuclear Cenerating Units in the Construction Pipeline as of December 31 , 1989, by Federal Region and State 
E1. Nuclear Gonerang Unit Reactors Ordered in the United States, 1953-1989, by Year of

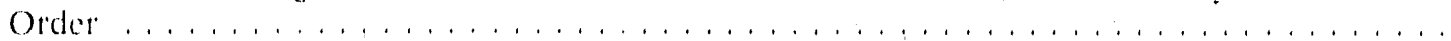

F1. Roster of Naclear Gencrating Lints Operable as of December 31, 1989, in Foreignt

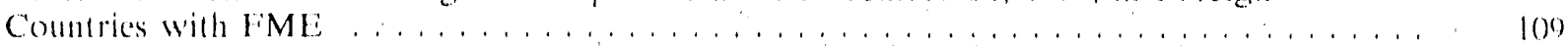

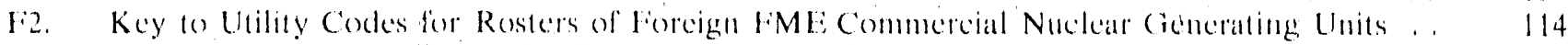

13. Key to Reactor Supplice Codes for Rosters of Foreign FME Commercial Nuclear

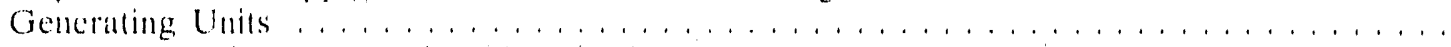

(1) Roster of Nuclear Generating Inits in the Constenction Pipeline as of December 31, joge,

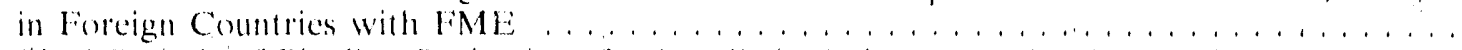

G2. Final Periods of Pipeline Projections for lastalled Nuclear Capacily for loreign FME

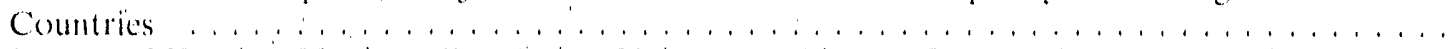

H1. Roster of Foreign Nuclear Generating Units Operable as of December 31, 1989, in Countries with Regulated Market and Centrally Planned Economies . . . . . . . . . . . . .

H2. Roster of Foreign Nuclear Generating Units in the Construction Pipeline as of December 31, 1989, in Countries with Regulated Market and Centrally Planned Economies .

11. Annual Projections of U.S. Operable Nuclear Capacity at the End of the Year .........

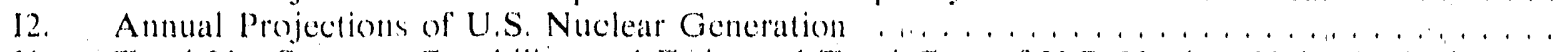

J1. Total Net Summer Capability and Estimated Total Cost of U.S. Nuclear Units Actively Under Construction, by Year Expected by Utility to Enter Into Commercial Operation . . .

J2. Reactor-Specific Data for Nuclear Units as of December 31, $1989 \ldots \ldots$

\section{Illustrations}

1. Domestic Nuclear Capacity, 1970-2010, and Status of Nuclear Generating Units at the End

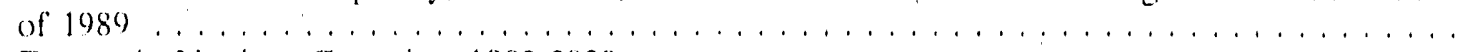

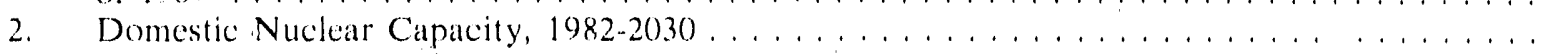

3. Nuclear Capacity Retiring by Year of License Expiration . . . . . . . . . . . . . . . . . . . .

4. Status of Foreign (FME) Commercial Nuclear Generating Units in the Construction Pipeline as of December $31,1989 \ldots \ldots \ldots \ldots \ldots \ldots \ldots$

5. FME Operable Nuclear Capacity at the End of the Year, 1989, and Projections for 1990)

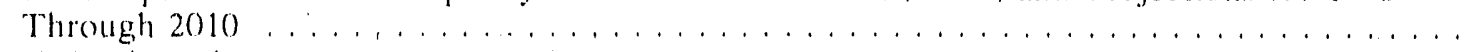

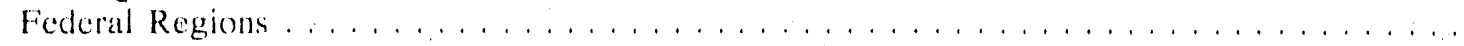

B1. Flow Chart for the WINES Methodology . . . . . . . . . . . . . . . . . . . .

J1. Status of Nuclear Plant Construction as of December 31,1988 and December $31,1989 . .$. 


\section{Executive Summary}

This report presems historicil dalla on commercial nuclear power in the United States, with projections of domestic nuclear capacity and generation hrongh the yeat 2030. Country-specific projections of muclear capacily and generation through the year 2010 for other countries in the world with free matket economies (FME) are also provided.' Additionally, information is presented regarding operable reactors and those under construction in countries with regulated market economies (RME) and centrally planned coonomies (CPE).

The Department of Energy is currently developing a National Energy Strategy (NES). The NES process include a comprehensive review of the current energy situation and an analysis of potential energy futures. National Energy Strategy results are not included in this report since they are yet to be officially released by the Department. The reader is advised that NES forecasts may vary from those found in this report.

\section{U.S. Commercial Nuclear Power}

In this report, U.S. nuclear capacity projections are discussed for the intermediale term through 2010 and the iong term through 2030. No New Orders, Lower Reference, and Upper Reference calses are presented for each of the projection periods. Sensitivity cases showing the effect of nuclear plant life extension are also included.

\section{Current Status: December 31, 1989}

Three U.S. nuclear units became operable and one was retired in 1989. This brought the total at the end of the year to 110 operable nuclear generating units in the United States, totaling 97.9 gigawalts of nel clectrical generating capacity ( $(\mathrm{WWe})$. These unit:" generated 529 net terawatthours (TWh) of electricity during 1989, or 17.8 percent of total U.S. electricity generation! (in. cluding 'on-utility generation) and 19.0 pereent of 10 tal utility-generated electricity. The overall average capacity faclor' (utilization rate) for nuclear units during 1989 was 62.3 percent, a decline from the excep- tiona!ly high 1988 rate of 63.5 percent, but still higher than any other year since 1978 .

Projections of Installed Capacity for the Intermediate Term, Through 2010

Projections for all cases show an increase in operable nuclear capacity to 104 net GWe through the year 2000. Most of the capacity in the construction pipeline is projected to be completed by 1992, and only two units are projected to retire. In 2010, the UpperReference-case projection of operable capacity is 122 nel GWe, the Lower-Reference-case projection is 103 nel ( $j W c$, and the $\mathrm{No}$-New-Orders-case projection is 100 net GWe. Ten more units are projected to retire by 2010 .

\section{Projections for the Long Term, Through 2030}

The Energy Information Administration's long-term projections for the Lower Reference and Upper Reference cases assume that U.S. utilities will maintain a diversified baseload electricity supply by continuing to rely on coal and nuclear energy.

The projections of operable nuclear capacity for the year 2010 are used as a point of departure for long-term projections through 2030 in the Lower Reference and Upper Reference cases. (It is assumed that newly ordered nuclear capacity will not become operable before 2006.) The projections of net nuclear capacity in the Lower Reference and Upper Reference cases increase to 1.34 and $184 \mathrm{GWe}$, respectively, in 20.30. The No-New-Order's-case projection of $6 \mathrm{GWe}$ in 2030) results from the assumptions that there will be no new orders of nuclear reactors in the United States, and that units in operation and under construction will relire 40) years after the issuance of their operating licenses, with minor exceptions. In a sensitivity case which alssumes that 70 percent of all U.S. capacity is life-extended for 20 years, the projected capacity in the No New Orders case in 2030 is 71 GWe. Depending on whether it is assumed that life-extended capacity displaces new orders, the range of projections for the

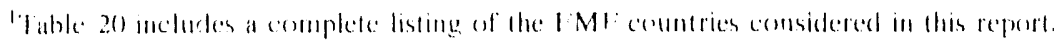

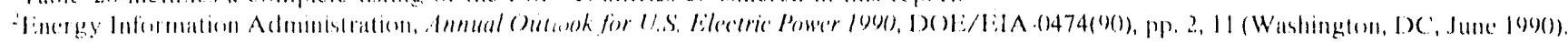

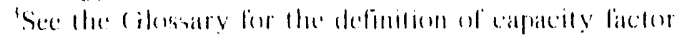




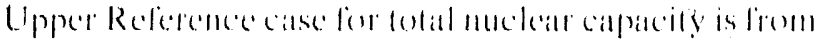

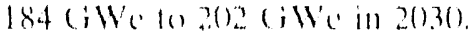

\section{Institutional and Technological Developments}

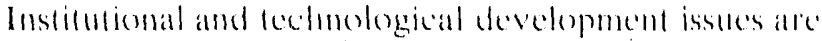
grouped inte three caltegoricese The list calcegry--envirommental issues-adiscusses recent progress on Clean Air Aot legislation in the United States and the status of the "greenhouse" or global climale change phenomenom. The second category-U.S. nuclear industry--includes a review of U.S. nuclear technology and a discussion of muselear power plant decommissioning. The third calcegery-the internationalization of the nuclear power industry-discusses global nuclear research and devel. opmontentivities.

\section{International Commercial Nuclear Power}

Current Status: December 31, 1989

Twenty FML mations (including the United States) produced elecericity from nuclear power in 1989. (Neither llaly nos Mexico generated electricity from their

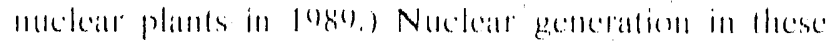

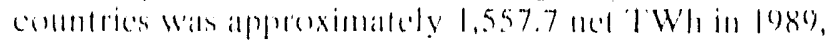

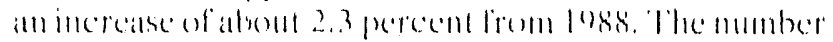

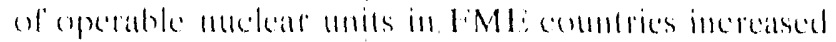

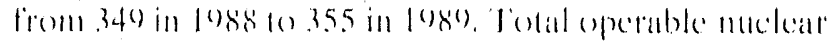

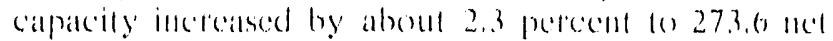

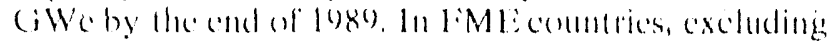
the Lented stalles, the loge comstrustion pipeline in. cluded 70 nucleal units, totaling about 0.5 net ciWe.

\section{Projections for IME Through 2010}

In the lower Refidence casce, total operable mectear capacily for countries belonging to the () jected lo increase from about 255 act (iWe all the end

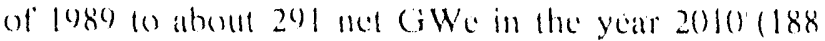
GWe when projected U.S. capacily is exeluded). lon nom-()ECD 1:MEcountrics, operable nucleall capacity is projected to reach about 28 GWe in 2010 . Pable list summarizes the loge nuckar capacity for the FME countrics as well as the nuclear capacity projec:tions in the Lower Reference case.

\section{Table ES1. Lower-Reference-Case Projections of FME Operable Nuclear Capacity}

\begin{tabular}{|c|c|c|c|c|c|c|}
\hline \multirow{2}{*}{ Countries } & \multirow{2}{*}{$1989^{\circ}$} & \multicolumn{5}{|c|}{ Capaclty (Net GWe) } \\
\hline & & 1995 & 2000 & 2010 & 2020 & 2030 \\
\hline I'nuted Statess & 983 & 103 & 104 & 10,3 & 116 & 134 \\
\hline Canalda & 12 & 16 & 15: & 19 & & \\
\hline 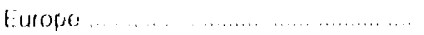 & 117 & 122 & 123 & 119 & .. & \\
\hline Far Fast . . . . . . . . & 41 & 47 & $5 ?$ & 66 & & \\
\hline 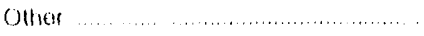 & 6 & 6 & B & 11 & . & \\
\hline Total FME & 274 & 294 & 302 & 319 & & . \\
\hline Of $: 0$ & 255 & 275 & 281 & 291 & & . \\
\hline Non-OEC D & 18 & 19 & 21 & 28 & .. & . \\
\hline
\end{tabular}

"Stalus ats of [lexomber 31,10839

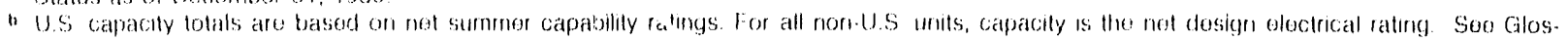
sary tor defirntermsi

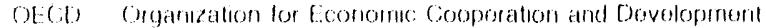

FME Feno Markot L comomos

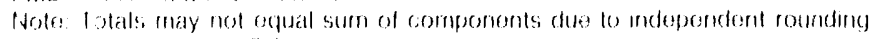

Souref Talles 8 and Tathe ?a 


\section{Operable Nuclear Units in Countries With Fegulated Market and Centrally Planned Economies}

In mations will regulated market economies (RME) and centrally planned conomices (CPE), of nuclear units will a total capacity of 43.8 net GWe were operable ats of December 31, 1989, compared with 43.6 net GWe at the end of 1988. In 1989, nuclear generat. tion for these countries was 274.2 net 'T'Wh, or about 14 percent of their totul electricity generation. The U.S.S.R. had 43 units totaling $34.2 \mathrm{GW}$ of nuclear capacity, or about 78 percent of the total nuclear capacity in the RME and CPE countries.

All the RME and CPE countries with operating nuclear plants or with nuclear plants under construction have experienced chente shortages of electrical power. Nuclear power, however, is likely or represent a smaller fraclion of total gencrating capacily than previously planned, and in some conntries noclear construction may be postponed. 'This reevaluation of nuclear porwer programs is due lo a lack of availuble capital and operational saffety concerms.

\section{Status of U.S. Plant Construction}

As reported o. Form EIA-254, two units entered commercial operation during 1989. The units have a net summer capability of $2.3 \mathrm{GWe}$ and a lotal eonstruction cost of $\$ 4.2$ billiom. Five units remaining under construction at the end of the year have a net summer capability of 5.7 GWe and a total construction cost estimated at $\$ 21.7$ billion. 


\section{Introduction}

This report presents the status at the end of 1989 and the outlook for commercial nuclear capacity and generation for all countries in the world with free market economies (FME). The report provides documentution of the U.S. nuclear capacity and generation projections through 2030. The longeterm projections of U.S. nuclear capacity and generation are provided to the U.S. Departmer of Energy's (DOE) Oflice of Civilian Radioactive Waste Management (OCRWM) for use in estimating nuclear waste fund revenues and 10 aid in planning the disposal of nuclear waste. These projections also support the Energy Information Administration's annual report, Domestic Uranium Mining and Milling Industry: Viability Assessment, and are provided to the Organization for Economic Cooperation and Development. The foreign nuclear caparaty projections are used by the DOE uranium entichment program in assessing potential markets for future enrichment contracts.

The Department of Energy is eurrently developing a National Energy Strategy (NES). The NES process includes a comprehensive review of the surrent energy situation and an analysis of potential energy futures. National Energy Strategy results are not included in this report since they are yet 10 be officially released by the Department. The reader is advised that NES forecasts may vary from those found in this report.

'The two major sections of this report discuss U.S. and foreign commercial nuclear power. The U.S. section (Chapters 2 and 3) deals with (1) the status of nuclear power as of the end of $1989 ;(2)$ projections of nuclear capacity and generation at 5-year intervals from 1990) through 2030; and (3) a discussion of institutional and technical issues that affect nuclear power. The nuclear capacity projections are discussed in terms of two projection periods: the intermediate term through 2010 and the long term through 2030. A No New Orders case is presented for each of the projection periods, as well as Lower Reference and Upper Reference cases.

The intermediate-term projections are derived from a detailed review of nuclear units both operating and under construction. The construction and regulatory status at the end of 1989 of each individual nuclear project and the progress loward its completion is assessed. The Upper and Lower Reference cases include. differing amounts of capacily that is assumed fo pestant from a current indefinite deferted stalus. These cases also assume the starlup of some newly ordered units between 2006 and 2010 .

The intermediate-ferm projections of installed nuclear capacity serve as a point of departure for the U.S. longterm projections through 2(130). The fong-term projeclions were prepared, in part, using the World lnte. grated Nuclear Evaluation System (WINES). WINES is an aggregated energy demand model that derives muclear generation requirements (and installed capacity) as a share of electrical generation, which is, in lurn, derived as a share of delivered energy. Delivered energy requirements are derived using a demand function that incorporates demographice, economic, and energy price factors.

Chapter 4 consists of (1) a general discussion of the status of nuclear power in the foreign FME countries; and (2) Lower Reference and Upper Reference case nuclear capacity projections for individual FME countries for 1995, 2000 and 2010. Chapter 5 reviews commercial nuclear power programs in free market, regulated market and centrally planned economies. Because of political developments in Easters Europe during the Fall of 1989, EIA has eliminated a separate appendix for discussions of commercial nuclear power programs in centrally planned economies, and incorporated the information in the body of the report.

The report also contains a number of appendices, Appendix $A$ is a map identifying the Federal regions of the United States. Appendix $B$ describes the reactor construction pipeline analysis and the WINES model, both of which are used in developing projections of installed nuclear capacity. Appendices $C, D, E, F$, and G contain delailed generating unit information for U.S. and foreign nuclear units that are operable or in the construetion pipeline. Appendix $\mathrm{H}$ contains resters of nuclear units that are operable or in the construction pipeline in countries with regulated market and centrally planned economies. Appendix I contains annual projections of U.S. nuclear capacity and associated electricity generation through 2030). Appendix J contains U.S. construction cost data and milestones for nuclear units in the construction pipeline. A cilossary is also included. 


\section{U.S. Commercial Nuclear Power}

The contencerial nuclear power industry in the United States remans substantially unchunged from a year ago. A variety of unsertainties remain concerning the industry, many of which conld individually affect its future. Some of the uncertainties, such ats waste dispensal issues, operating and maintenance costs, and the pos. sibility of extending operatting lives, pertain for existing units. Others, such as capital costs, lechnolengy devel. opments, regulatory environments, and the structure of the industry apply to anticipated new orders. Most of these isstues were addressed in some manner during 1989, but, in general, their resolution will evolve aver a longer time period.

This chapter describes the status of the domestic commercial nuciear power industry at the end of 1989, as well as projections for the intermediate lerm (through 2()10) and the longer term (through 2(03()). The assumptons underlying the projections and the methodologies for producing them are described. Finally, the results are compared with projections from other sources.

\section{Status as of Decamber 31, 1989}

The status of U.S. nuclear power plants that were eithere operable or in the construction pipeline at the end of 1989 is shown in Table 1. There were 110 operable units at that time," with a total net capncity of 97.9 gigawalts-clectric (GWe).

As of December 31, 1989, here were 11 nuclear units with a total net capacity of 13.1 GWe in the construction pipeline. Of these, 1 unit had loaded fuel and was undergoing low-power testing. The remaining 10 had received construction permits, although construction of 6 units has been indefinitely deferted. One unit was retired during 1989. There were 121 nuclear units in operation and in the pipeline at yeur-end with a combined net summer capability of 111.0 GWe (see A.p. pendices $C$ and D for a complete listing of operable nuckear units and those in the construction pipeline).

\section{Table 1. Status of U.S. Nuclear Generating Units}

as of December 31, 1989

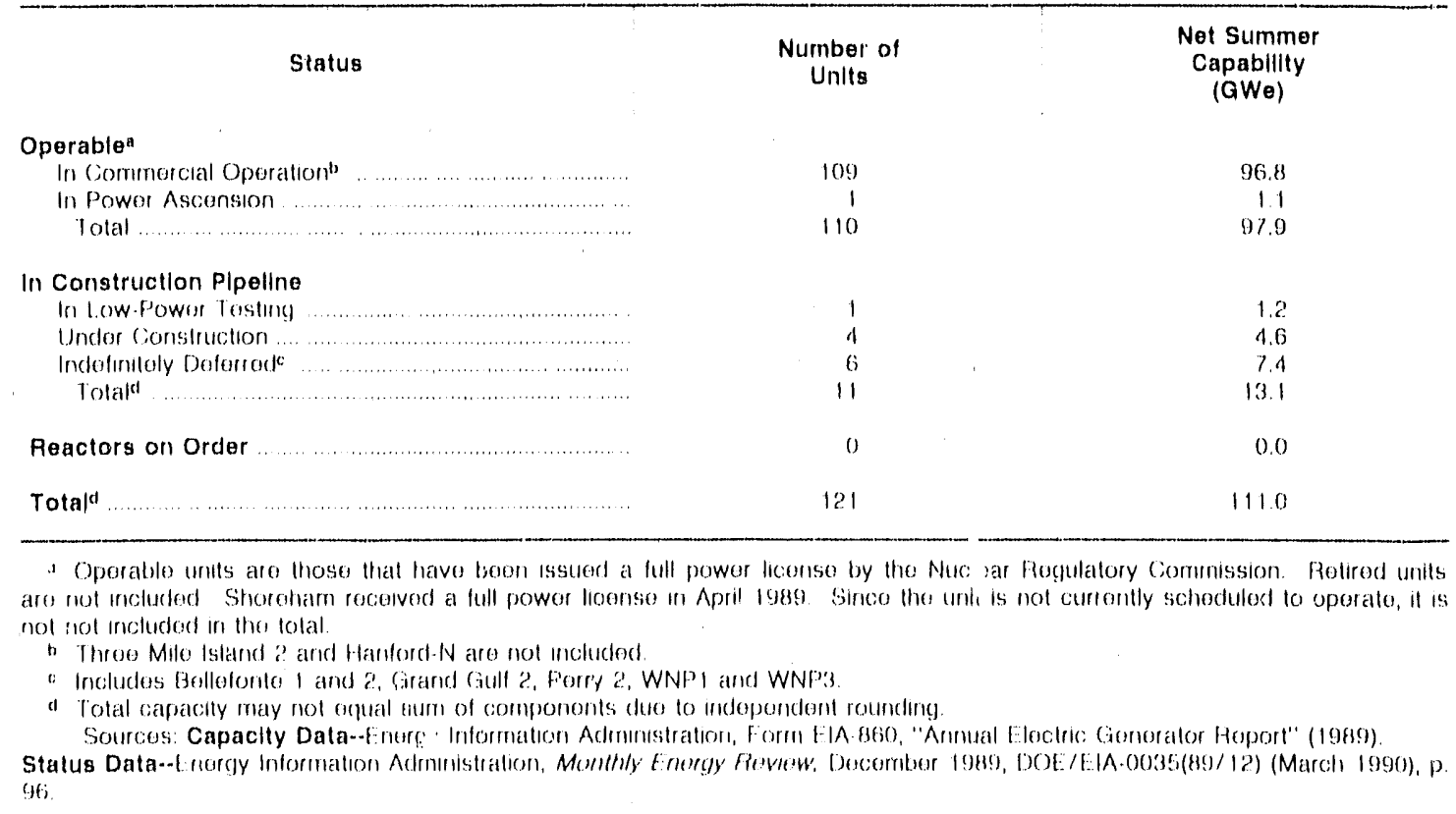

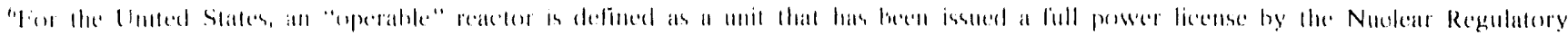
(') IIII!) 


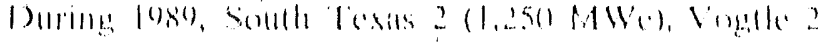

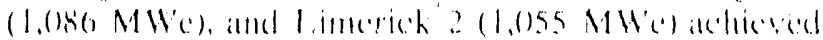

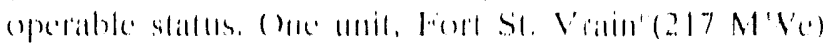

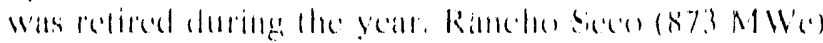

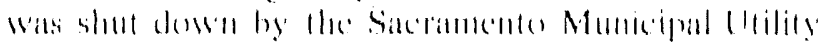

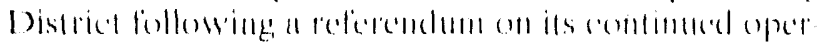

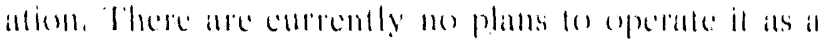

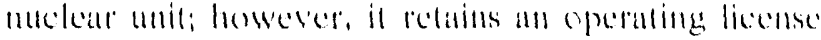
and it is included in the "operable" categery in Thale 1. Shorehann, owned by long îsland lighting ('o, in New Youk stalce, is nol included in the lolals. The unit received a full-power liceise in April fo89; however,

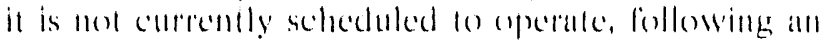

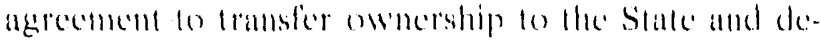
commission it, Appendis li. combaims al complete listing

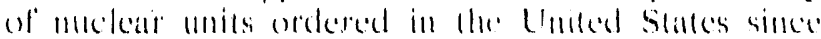

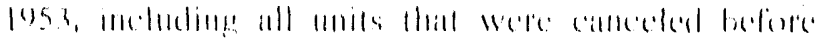
(ain)plelions.

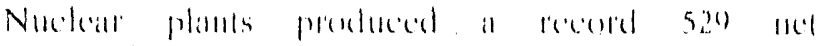

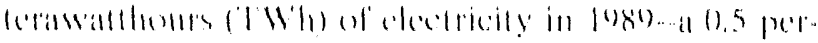

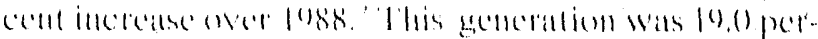

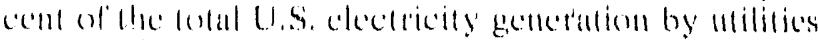

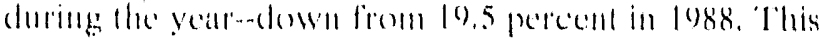

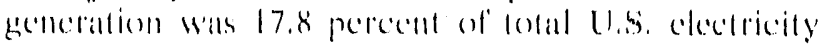

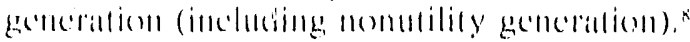

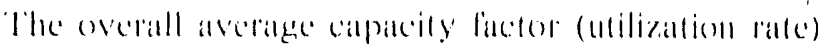

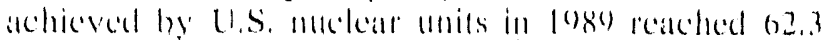

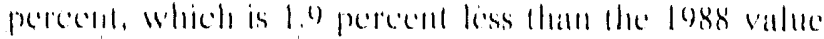
and higher than any ollow geatr sitce 1978."

\section{Table 2. U.S. Nuclear Generating Units Achieving the Best Lifetime Performance Records}

\begin{tabular}{|c|c|c|c|c|}
\hline Ranklng of Unit & Operating Utillty & $\begin{array}{c}\text { Reactor } \\
\text { Type }\end{array}$ & $\begin{array}{c}\text { Year of Initial } \\
\text { Operation }\end{array}$ & $\begin{array}{c}\text { Lifetlino } \\
\text { Avertige } \\
\text { Value } \\
\text { (peroent) }\end{array}$ \\
\hline & HIghest Capacily Factors & & & \\
\hline 1. Peane |siand:" , .... .... & Norlhom States Power & PWH & $19 / 4$ & 34.3 \\
\hline ¿ Sil l.uget $: \ldots \ldots$ & Horida lower and tyme & PWH & 1983 & 82,9 \\
\hline$\ldots \ldots>1$ & Wisconsan f'uthle senvices & HWI & $1 ! 3 / 4$ & 81.6 \\
\hline 4 dosuph M. farloy ${ }^{\prime} \ldots \ldots \ldots . . . . .$. & Alatlatrala f'ewor & PWH & $19+31$ & (4) 6 \\
\hline 5. Poml Buach ? & Wisconsin Electric Howor & PWH & 1972 & 80.7 \\
\hline 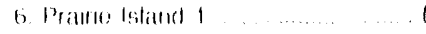 & Northenn Stalles Power & PWH & 1973 & 80.6 \\
\hline I Callawaly 1 . . ......... . . & Unow bienctric & PWH & 19834 & 79.4 \\
\hline 8. Haddan fNock ............... & lonneatucat loght and Powen & PWII & 1967 & 77.3 \\
\hline 9. Walderlorali & I crusbanla H\&I & PYA & 19856 & 76.2 \\
\hline$\ldots \ldots \ldots \ldots \ldots \ldots$ & Kansas Caly P\&a and Kansas Gas \& t loc & I'WII & 1945 & $|t i|$ \\
\hline & Lowest Forced Outage Fates ${ }^{a}$ & & & \\
\hline I Poml Beals ? & Wisconsen tilecitere Peiwer & PWA & $107 \%$ & $1 \%$ \\
\hline 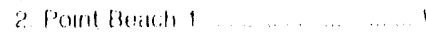 & Wisconsinn E lecelre: Puwen & PWF & 1970 & 10 \\
\hline 3 Kendumes: & Wisconsin Public Survice: & I'WF & 1974 & 26 \\
\hline a Dablo Canyom $1 \ldots \ldots \ldots$ & Pacific: Gas athel Eocoric: & PWH & 19834 & 28 \\
\hline 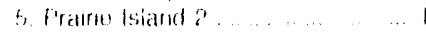 & Norlbern Stalos Powor & PWA & 1074 & 30 \\
\hline 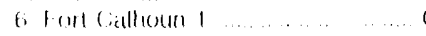 & Omatha Public Frowor Oistres? & PWF & 1973 & 30 \\
\hline 1. Callaway $1 \ldots \ldots \ldots$ & Union tolocine: & FWh & 1984 & 3.3 \\
\hline 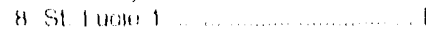 & Fonda Pewer and ligght & FWI & 1976 & 3.4 \\
\hline 9. Montocollo 1 & Northenn Statos Power & BWIS & 1971 & 4.0 \\
\hline 10. Joseph M. F arley '. & Alabana Powor & PWH & $|y| s \mid$ & 46 \\
\hline
\end{tabular}

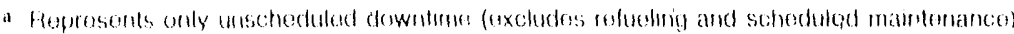

HWA Honline. Wator Reactor

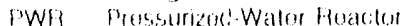

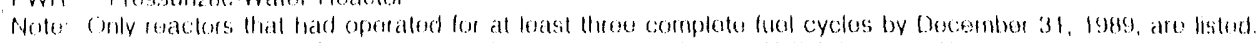

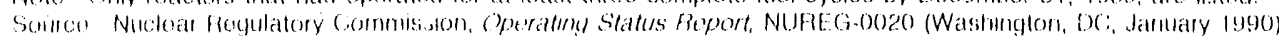

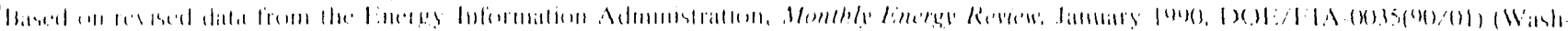

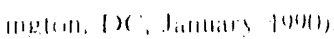

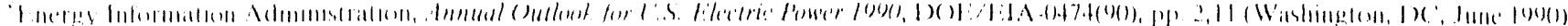

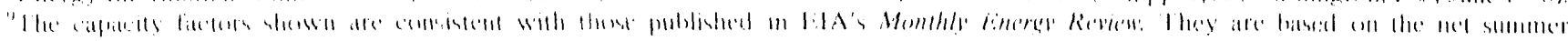

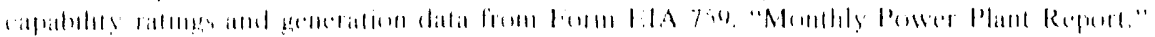


Units achieving top operating performance (capacity factors) during 1989 were Three Mile Island 1 (102 pereeni), Prairie lsland 1 (99.7 percent), Hatch 1 (97.7 percent), Wolf Creek (97.7 percent), Maine Yankee (97.0 percent), Davis-Besse (96.0 petecent), and Sequoyah 1 (95.0 pereent). Twenty-two other units, the same number as in 1988, had anmual capacity factors above 80 percent." (It should be noted that a unit's annual capacity factor is highly dependent on whether or not it is refucled during a particular year.) Table 2 shows top performing U.S. units based on $(w 0$ measures-cumulative capacity factors and cumulative foreed outage rates. 'The difference between 100 percent and the cumulative capacity factor for each reacfor represents the time spent in refueling. scheduled maintenance, and unscheduled downtime. The forced outage rate represents only unscheduled downtime. In general, the units with low foreed outage rates also had high capacity factors. In 1989, wo newer units, Waterford 3 and Woll Creek displaced older units on these lists. Note that only one boiling-water reactor $(B W R)$ is on either of the lists.

\section{Outlook for the Intermediate Term, Through 2010}

Thi: section presents projections of domestic installed nuclear capacity and net electrical gencration from 1989 through 2010 for the No New. Orders, Lower Reference, and Upper Reference cases. These cases describe a range of values, which vary as a result of differing assumptions about the schedules for individual nt:clear units that currently remain uncompleted as well as assumptions about newly ordered units. These cases should not be interprefed as exhatusting the range of possible nuclear supply futures. Nuclear plant life extension is not assumed to oceur in these cases but is covered in a sensitivity case later in this chapter. No effects of expected changes in the Clean Air Act are included; however, a discussion is included in Chapter 3.

\section{Basic Methodology}

The methodotogy used in deriving the intermediateterm capacity projections was the same as that used to prepare EIA analyses presented in the Anmual Energy Oulook lQDO (AEO) and the Anmesal Oullook for U.S. Electrie Power. In lact, the No New Orders case documents the U.S. muclear sapacity and generation projections throwgh 20 !( ) in all cases in the 1990 AfO. In general, this methodology entails a detailed review of units under construction and an estimate of the year for first operation of each unit, a method often described as "pipeline analysis" (Appendix B). The Lower Reference case is a limited growth case in which lead plants are assumed to operate F gioning in 2006. The Upper Reference case includes a supply constrained growth transition in which the new unit anmual ordering rate follows a trend from one GWe in 2006 to $6 \mathrm{GWe}$ in 2010. Projections of electricity generation ior the No New Orders, Lower Reference and Upper Reference cases are obtained from the International Nuclear Model (INM).

\section{Intermediate-Term Case Assumptions}

In addition to the reactor construction pipelinc approach, the foliowing assumptions were used to develop the intermediate-term projections.

\section{Assumptions Applicable to All Cases}

- It is assumed that nuclear units will operate for 40 years from the issuance of their operating license even though prior to 1982 nuclear operating licenses were issaed for 40 years, beginning with the issuance of a construction permit." An electric utility may petition the Nuclear Regulatory Commission (NRC) for a redefinition of the operating license for those nuclear units to recover the construction time. It is assumed that those licenses will be redefined. A current cxception to this rule is the projected official retirement of Rancho Seco in 1990.

- Nuclear units are assumed to supply baseload power.

- The average equilibrium sycle capacity factor for existing units is assumed to increase to 68 pereent in 2010. The average capacity factor for units in their first fuel cycle is assumed to be 55 percent.

- Estimates of hirst operation dates for the remaining nuclear units under construction reflect hisforical construction performance, any regulatory or financial constraints, and regional electricity denand considerations.

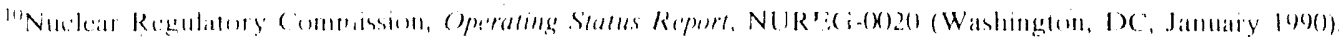

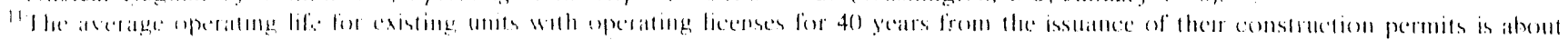
it yalu.
} 
The following assumptions apply to the Lower and Upper Reference cases.

- Utilities undertaking long-term investment are essentially assured a return on those investments.

- Some manner of turnkey pricing or risk sharing is available to utilities.

- A high-level waste repository is constructed and available to receive spent fuel by 2010 . In the interim, either legislation is passed which decouples the construction of a Monitored Retrievable Storage (MRS) facility from the siting of the repository as is currently required by the Nuclear Waste Policy Act of 1982, or, tangible progress is made on the permanent site.

- Nuclear power will be economically advantageous over alternative baseload generating technologies in some regions of the country and construction and licensing leadtimes are held to 6 to 7 years.

- Financial protection of the industry is available through extension of the Price-Anderson Amendments Act of 1988 or by sone similar type of liability coverage.

- New units are assumed to be improved or advanced light-water reactors.

\section{Assumptions Applicable to the Upper Reference Case}

- The reactor licensing process becomes effectively certain This includes legislated one-step licensing, the availability of a preapproved standardized designt, and advanced site certification.

- All units that are indefinitely deferred, with the exception of Grand Gulf ?, are completed and become operable. (The licensee has announced the cancellation of Grand Gulf; however, if has not been officially removed from the NRC list of reactors).

- New reactor orders resume in 1999 and initially have a 7-year leadtime. The ordering rate follows a linear trend from 1 gigawatt (GWe) in the first year to 6 OWe per year 4 years later. Operable capacity from 2006 through 2010 reflects this ordering rate.

(It should be noted that, in anticipation of new orders, the DOE planning basis for the advanced reactor program is premised on the assumption that these orders will commence in 1995 and begin commercial operation by 2000 ).

\section{Assumptions Applicable to the Lower Reference Case}

- The reactor licensing process becomes less contentious, and includes administrative one-step li. censing, the availability of a preapproved standardized design, and advanced site certification.

- Three of the indefinitely deferred units are completed and become operable. Two new lead plants are completed for operation during the 2006 through 2010 time period.

- The following units are assumed to be canceled: Grand Gulf 2, Perry 2 and WNP. 3.

\section{Intermediate-Term Projections}

The EIA projection for nuclear capacity in the period from 1990) through 2010 is for continued completion of units under construction and varying degrees of activity toward the resumption of orders for new units. Operable nuclear capacity, in all cases, is expected to increase from 97.9 net $G W e$ at the end of 1989 to 103.8 net GWe in 20(0). The average annual growth rate in operable nuclear capacity is 0.5 percent per year from 1989 to 2000

The Upper-Reference-case capacity, as shown in Table 3 , increases from 103.8 GWe in 2000 to $122.1 \mathrm{GWe}$ in 2010 , a growth rate of 1.6 percent per year over the 10-year period. The capacity totals assume replacement of about 6.4. GWe of retiring nuclear capacity with new nuclear capacity by $2010 .{ }^{2}$ 'This case assumes that five units for which construction is currently halted are eventually completed. The Lower-Reference-case capacily projections increase to 105.0 GWe in 2005 and decline to 102.9 GWe in 2010. This case assumes that three units for which construction is currently halted are eventually completed. There is a net decline in this projection because of the retirement of $6.4 \mathrm{GWe}$ of capacity. Capacity projections for the No New Orders case match the growth cases through 2000 , then decline to 99.7 GWe by 2010 . The regional breakdown for the No New Orders case is shown in. Table 4. From this it can be seen that most of the early retirements (under the 40-year life assumption) occur in the Northcast.

Nuclear generation by region is shown for 1989 and the No New Orders case in Table 5. The 1989 percent share for nuclear ranges from 34 percent in New England, to nearly zero in the North Central region. The nuclear share of generation in three regions.. New York/New Jersey, the South Atlantic and the Midwest

12 The 6.4 GWe of retisenents is based upon the operable dentes in Appendix C and the assumed 40 year ofkrating lives. 
Table 3. U.S. Operable Nuclear Capacity at the End of the Year, 1989, and Projections for 1990 Through 2010

\begin{tabular}{|c|c|c|c|}
\hline \multirow{3}{*}{ Year } & & Capacity (Net GWe) & \\
\hline & $\cdot$ & & \\
\hline & No Now Orders Caso & Lowor Folerence Caso & Uppor Rotorenco Caso \\
\hline (., & 97.9 & 97.9 & 97.9 \\
\hline 1990 …1....... & 99.3 & 993 & 99.3 \\
\hline 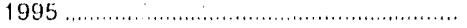 & 102,8 & 102.8 & 102.8 \\
\hline 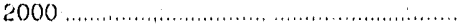 & 103.8 & 103.8 & 103.8 \\
\hline 2005 & 103.8 & 105.0 & 1050 \\
\hline 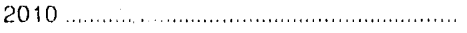 & 99.7 & 1029 & 1221 \\
\hline
\end{tabular}

a Capacity valuos are basod on not summer capability ratings.

b Actual.

Sources: Capacitles.-No Now Orders Case and Lowor and Upper Relorence Cases through 2005 . Energy Inlormation Auministralıon, form ElA-860, "Annual Electric Gonerator Report" (1989). Gapacity Valıes for 2010 in Lower and Uppor Rotorence Casos include nowly ordored capac. ily with unit capacitios from reactor manufacturors.

\section{Table 4. U.S. Operable Nuclear Capacity by Federal Region, 1989, and Projections for 2000 and 2010}

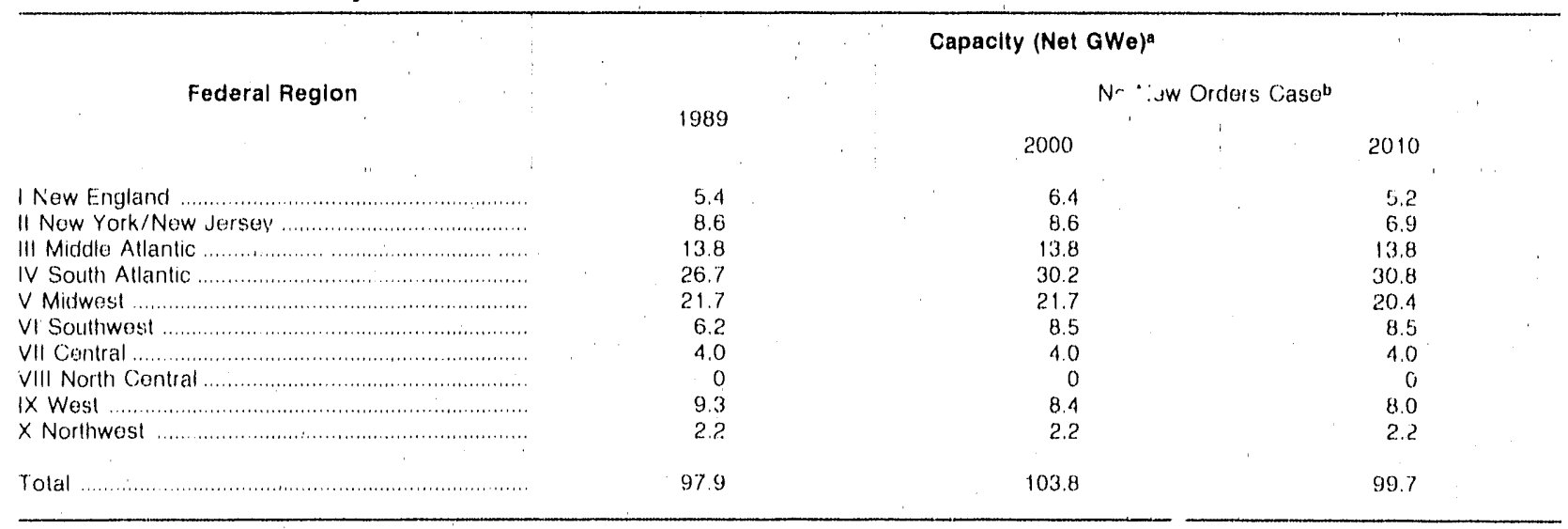

a Capacity values are based on net summer capability ratings.

b Totals may not equal sum of components due to independent rounding.

Sources.. Capacities: Ener(") Information Administration, Form ElA-860, "Annual Electric Generator Reporl" (1989). Projections.- Energy In Iormation Adrninistration. Annual Oulook for Electric Power 1990, DOE/EIA-0474(90) (July 1990).

\section{Table 5. U.S. Nuclear Generation in 1989 and Projections for 2000 and 2010}

\begin{tabular}{|c|c|c|c|c|c|}
\hline \multirow{2}{*}{ Federal Region } & \multicolumn{2}{|c|}{$\begin{array}{l}\text { Actual } \\
1989\end{array}$} & \multicolumn{3}{|c|}{$\begin{array}{l}\text { No New Orders Case } \\
(\text { Net TWh })^{a}\end{array}$} \\
\hline & Net TWha & Porcent Shareb & 2000 & : & 2010 \\
\hline 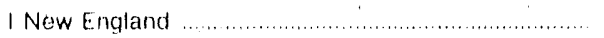 & 33.1 & 34.0 & 37.6 & & 34.3 \\
\hline If Now York/Now Jersey ............................................ & 45.9 & 26.7 & 44.0 & & 36.9 \\
\hline 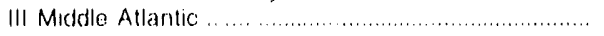 & 56.1 & 17.2 & 77.1 & & 81.6 \\
\hline 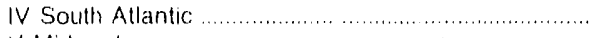 & 150.8 & 24.6 & 162.0 & & 184.8 \\
\hline 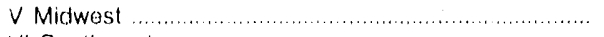 & 130.6 & 250 & 119.4 & & 120.2 \\
\hline$\ldots \ldots \ldots \ldots \ldots \ldots \ldots \ldots \ldots \ldots \ldots$ & 31.2 & 8.0 & 50.5 & & 53.5 \\
\hline 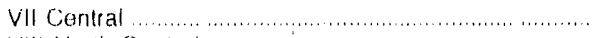 & 29.3 & 20.5 & 21.6 & · & 22.9 \\
\hline 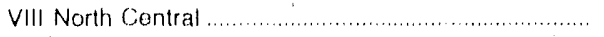 & 5 & .3 & 0 & & 0 \\
\hline 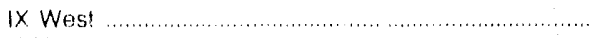 & 40.4 & 19.0 & 48.4 & & 49.2 \\
\hline 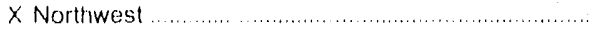 & 11.4 & 7.9 & 11.1 & & 11.8 \\
\hline 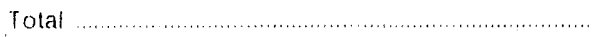 & 529.4 & 19.1 & 571.7 & & 595.1 \\
\hline
\end{tabular}

a TWh. Terawatthours. One TWh is equivalent to one billion kilowathours

- Nuclear gerierated electricity as a percentage of electricity generated from all sources. Note: Totals may not equal sum of components due to independent rounding.

Sources: 1989 Data.- Energy Information Administration, Form ElA.759, "Monthly Power Plant Report" (preliminary data). Projectlons--Finergy Information Administration; Anrual Outlook for U.S. Electric: Power 1990. DOE/EIA-0474(90). (Washıngton, DO, June 1990). 
is around 25 pereent. A modest projected capacity factor improvement permits an increase in generation by 2010 at an annual rate of 0.6 percent, in spite of the slight capacity decrease.

Figure I summarizes domestic maclear capacily from 1970 through 1989, projections through 2010, and the status of nuclear projects at the end of 1989. The Up- per-and Lower-Relerence-case projections are coincident through 20(0). This similarity among cases reflects the inflexibility of construction schedules for nuclear units that are nearing completion. The leveling off in projected capacity in these cases reflects the fact that only four units reman actively under construction and only two units that are currently indefinitely deferred are assuried to become aperable by 2005 .

Figure 1. Domestic Nuclear Capacity, 1970-2010, and Status of Nucieer Generating Units at the End of 1989

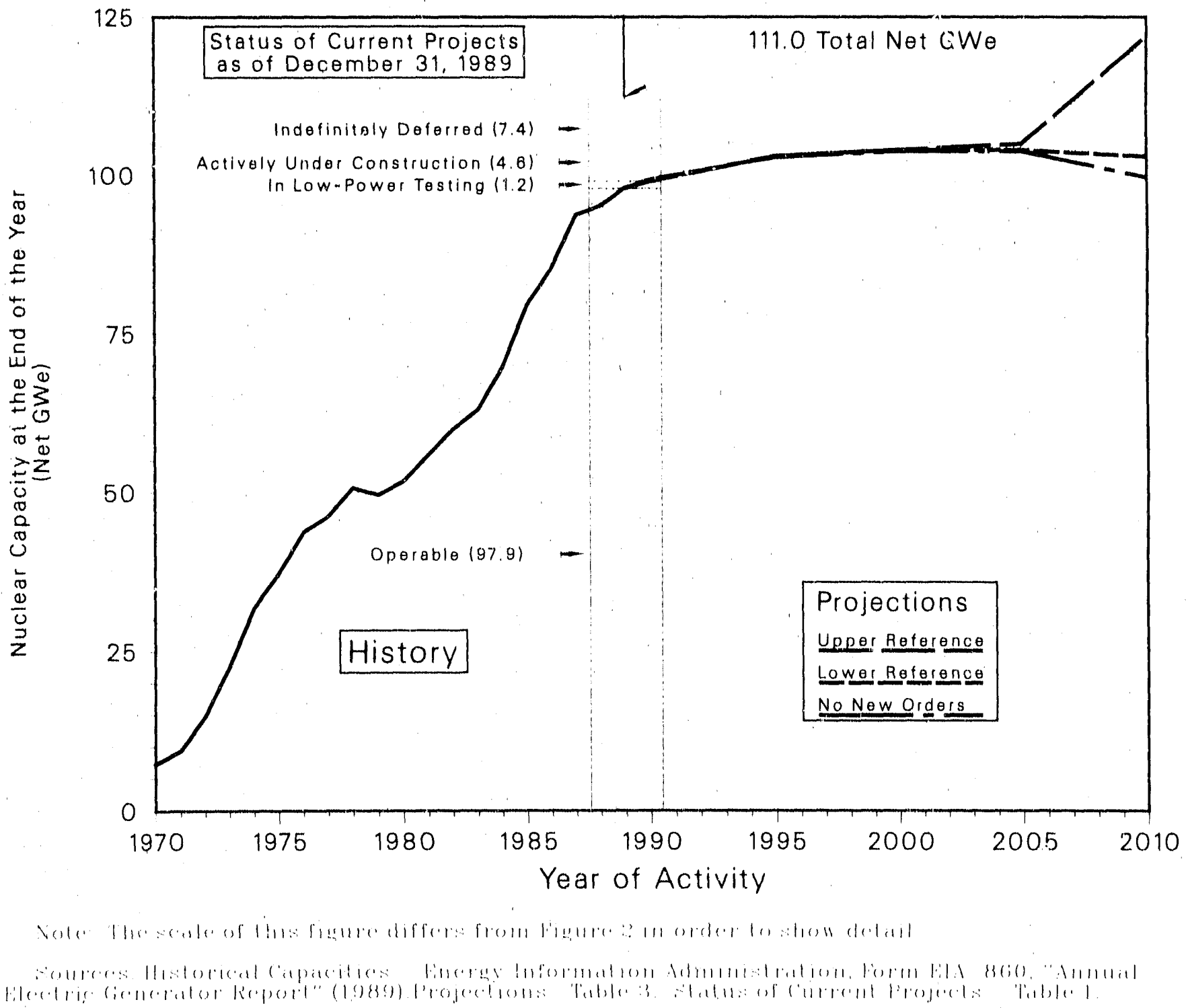




\section{Prospects for the Long Term, Through 2030}

l.ong-term projections of installed muclear capacily and electricity gencraltion are used to estimate nuclear wasic mamagement needs and ficel eycele repuirements and for planming reguirements of the nuclear industry (utilities and cquipment suppliers). The Nuclear Waste Policy Ace of 1982, as amended in 1987, mandates the establishment of a repository for the disposal of highlevel radionetive waste and the collection of fese frem utilities to finance this repesitery. "The office of (ivilian Radinaletive Waste Mallagement ases He forecasts of capacity and gencration over the long term to plan for waste volume and to estimale the adergacy of the lees. This sectiont presents a range of muclear capacily projections for s-ycatr intervals from 2011 through 20.30. These projections result fromalternative sets of assumptions atssociated with a No New () relers cast: and with lower-Reference- and UpperReference-case nus:lear supply scemarios.

- Upper Reference. A traditional demand-driven capacily groweth cass, prodeced by the World Inregrated Nuclear Iivalualion System (WINLS), post 2010. "The parameter values which define these projections assume a rohust economic and clectrical demand growth and, following a $10 \mathrm{~cm}$ poraty plateate, restoration of a substantial nuclear role in providing bascload clectrical power. WINISS is a longeterm aggregated model that derives nuclear generation requirements (and installed capacity) as a share of delivered energy. Delivered energy is projected msing a demand funceicon composed of economic: groweth and the glowh ralc for the price of ageregate conergy. The WINES methodology is described in detail in Appendix $\mathrm{B}$.

- I.ower Reference. A case in which a limited numher of introductory lead units provide assurance of technical and ecomomic feasibility of nuclear power thas leading fo additional orders. The car. pacily resulting from additional new orders is projected hy WINES for the period after 20!0. The assumptions for the lower-Reference-case WINES projections assume a more modest economic growith, a somewhat longer delay before a resumption of sustained plant ordering, and a reduced share (from the present) of generation prose vided by nuckar power.

- No New orders. A casce in which capacily projections depend sololy on the assumption of no new orders and, in general, reactor retirements after 40) years of operaling lifo.

Each of hese cases is discussed in detail in the following sectionti.

\section{Long-Term Case Assumptions}

Major assumptions that govern the LIA IowerReference-case and Upper-Reference-case projections for the long term (20)1 through 2(0.30) are the same as the assumptions stated for the intermediate term.

The Lemere Reference case is, for the most part, a supply-driven case based on a detailed examination of the U.S. nuclear power equipment manufacluring industry. In this case, new capacity projections ale diveloped from information and assumptions related fo the limitations on the ability of the industry lo respond (o) new nuclear orders. The fact that no unit ordered since 1974 has been built has caused a general retrenchment in the industry, the larger companies, such ats reachor manufacturers and architect-engincers (Al:'s), have shofted into the service business, while smaller companies, such as subtier supplices, have left the industry. Furthermore, the uncertaintics of future costs, regulatory treatment, and leadtimes translate inle a large risk factor, and the manner in which this risk will be borne is also uncertain. Resolution of the riskbearing isste may be the principal driver of the industry's restructuring. is Such restructuring could include an increased foreign component. Many utilities are expected lo delay nuclear orders until one or more industry leaders suceessfully complete a project "on time and within budget."

The Lewer Reference case assumes that only a limited amount of newly ordered nuclear capacity will become operable between 20(15 and 2010). Assuming these new orders are completed suceessfully, some other utilitics are projected to begin ordering new mints; however, only those with successful nuclear programs would be expected to replace reliring unils with nuclear units. The projected capacities for 2015 through 2030 are produced by WINES based on the assumptions provided in Table 6.

In the Upper Reference case--the demand driven casc--fong-term demand for electric power (and consequently molear power) is influenced by a mumber of fictors. These include the perecived level of long-term

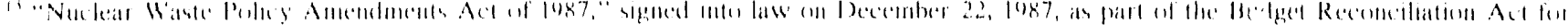

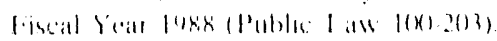

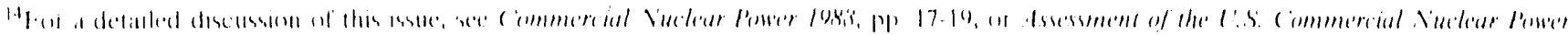

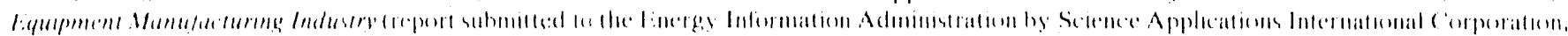
Mulati, V'A. Derimber 1987)

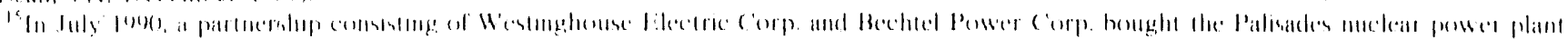

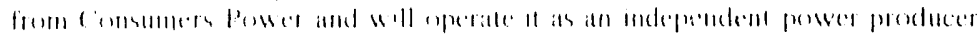




\section{Table 6. Assumed Parameter Values of the WINES Model for the United States, 2010-2030}

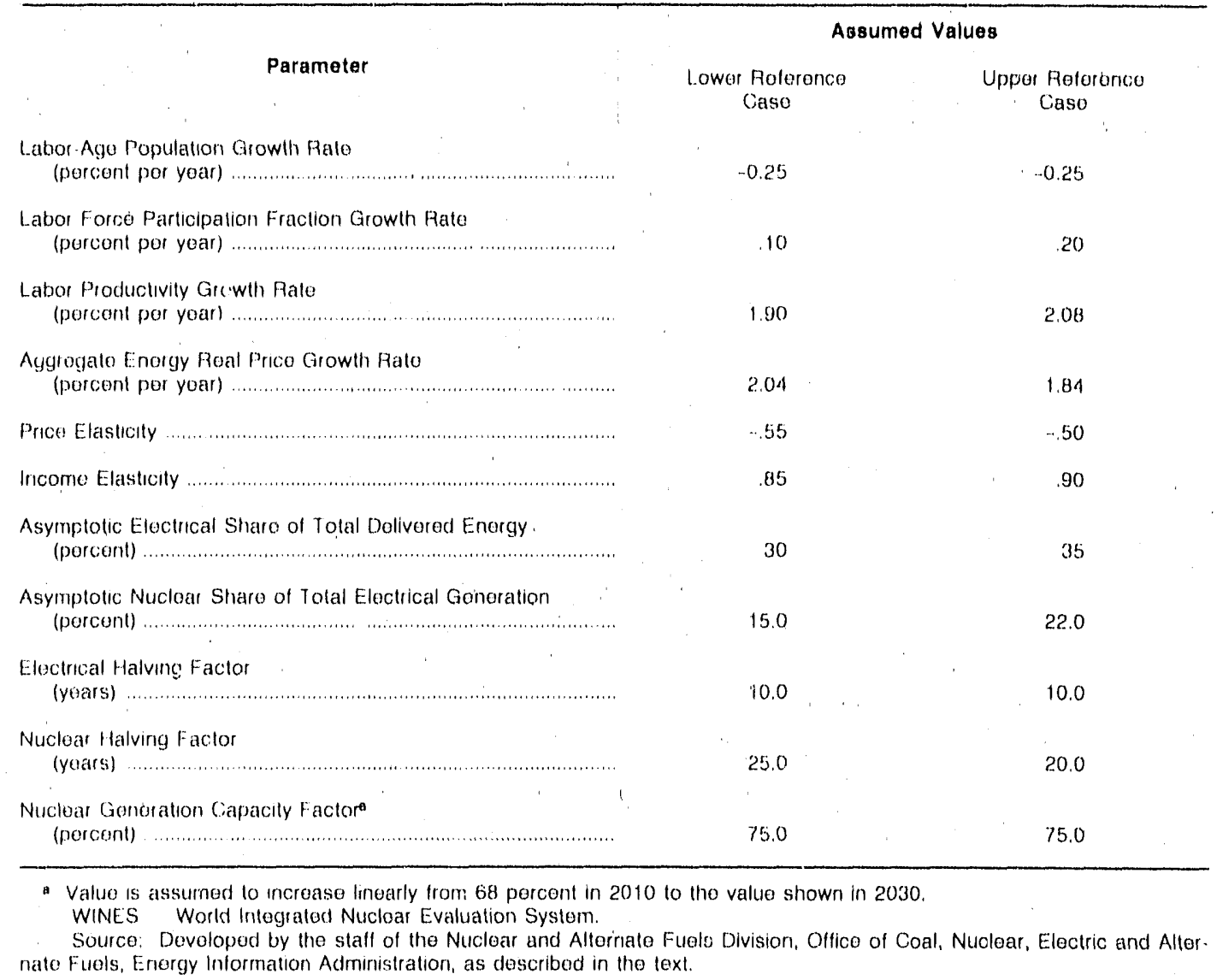

economic growth and its relationship to electricity demand, and the cost and availability of electricity from all sources. An examination of historical trends suggests that the relationship between Grois National Product (GNP) and electricity consumption is much more stable than that between GNP and total energy. For example; from 1979 through 1989, total energy consump. tion per constint 1982 GNP' dollar dropped by about 21 percent. The consumption of electricity in kilowatthours ( $k$ Wh $)$ per constant 1982 GNP dollar during the same period dropped by only 2.7 percent. th Several features of electricity make it an attractive energy option, and this suggests that its fraction of total energy demand will continue to grow as it replaces other forms of energy. Among the advantages of electrical energy are the following:

- Il can be generated from many primary resources, allowing for diversification of supply.

- It cain replace most oflerer forms of energy supply.

- It is clean, versatile, and efficient at the point of consumplion.
The Upper-Reference-case projections assume that there wi ${ }^{\prime}$ be increasing electrification, and that utilities will rely increasingly on coal and nuclear fuels in constructing new capacity to meet anticipated growth in the demand for electricity. For this to occur, there must be changes in existing economic and regulatory conditions, new developments in the technology, and greater public acceptance of nuclear power. The L.ower-Referencc-case projections assume a similar environment, however, with a longer delay before reactor orders resume and more caution by utilities in selection of the nuclear option.

The assumption that reactor orders will resume rests on the proposition that changes in the factors described above will make nuclear power an altractive option. Political, environmental, and oconomic issues related to the large-scale expansion of the use of coal, which is the primary alternative to nuclear power for baseload generation, could induce utilities to give stronger consideration to nuclear power. Among these issues are the movement foward stronger air quality control regulations (principally to address the acid rain issue), and

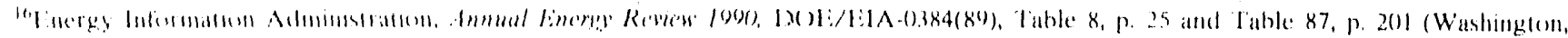
1) . Mal $10(1)$ 
uncertainties about the effects of the buildup of carbon dioxide $\left(\mathrm{CO}_{2}\right)$ in the atmosphere (the "greenhouse of fect") due to the combustion of fessill fuels.

Exactly when significant amounts of new baseload generating capacity will be needed depends on retitement schedules, changes in utility load factors, levels of conservation, pencetration of renewable energy and cogencration technologies, and rates of electricity demand growth. Considering these factors and current utility construction programs, it is estimated that addi. tional gencrating capacity may be needed in some regions of the country hy the early 190()$^{\prime}$ s. Beth reference cases assume that new units will be improved or advanced light-water reachors. High-temperalure gas reactors and liquid metal reactors are assumed to be available for commercial ordering later in the plegjection period.

The paramelers used in WINE:S and their values for the Lower Reference and Upper Reference cases are presented in Table 6. Within Ha WINES model framework, economic (GNP) growth is defined as the sum of growth rates for the labor-age population, the labor force participation fraction, and labor productivity. The labor-age population growth rate is derived from World Bank population forecasts." It is projected fo grow by about (0.6 pereent antually from 1990) through 2010 and then 10 decline by about 0.3 pereent per year through 2030). The labor force participation fraction is assumed to increase at anmual rales of $(0.10$ (0) 0.20 percent. Labor productivity is assumed to glow at a rate of 1.9 to 2.1 percent per year. These growth rates imply real (i.e., adjusted for inflation) GNP growth rates of 1.8 and 2.0 percent per year for the Lower Reference and Upper Reference cases, respectively, for the period from 2010 through 2030. The GNP growth rate for the lewwer Reference case is consistent with one being discussed to support a draft National Energy Strategy Reference scenario, and the growth rate for the Upper Reference case is consistent with the low World oil Price catse of the Annmal Energy Ontlook loge. ${ }^{10}$

The function describing growth in demand for delivered energy uses these growth rates, plus assumptions regarding growth in the real price of aggregate energy and the corresponding price and income elasticities of demand for entergy, to derive delivered conergy requirements. The real price of aggregate energy is assumed to increase at anmual rales of 2.0 and 1.8 pereent for the Lower and Upper Reference cases, respectively. These price growth rates are derived from the DRI Energy Model. The price clasticities are assumed to be
-0.55 and $-(0.50$, and the income elasticities are assumed to be 0.85 and $(0,9()$.

The electrical share of delivered energy and lhe nuclear share of electricity are derived asing market penctration functions. These functions require assumplions regarding the long-run asymptotic shares and the halving factors." The halving factor determines how fast the share from the base-year value approaches the asymptotic value. The eontinuing uncertainty regard. ing waste disposal, licensing, and safety verificalion proedures makes it likely that more time will be required to achicve the nuclear asymptotic share. This is reflected in the nuclear halving factor values of 20 and 25 years for the Upper Reforence and leower Redcrence cases, respectively. The electrical halving facter is 10 years in both cases. The asymptotic cécedrical share of delivered energy is assumed to be $3($ ) pereent in the Lower Reference case and 35 pereent in the Upper Reference casce, The 1989 actual electrical share is about 14.7 pereent of delivered energy. The asymptotic nuclear share of electrical generation is assumed to be 15 percent in the lower Reference case and 22 pereent in the Upper Reference ("isc; the loge) nuclear share is 19.0 percent of utility clectrical generation and 17.8 perecent of total generations The average capacity factor in both reference cases is assumed to increase from current leveis 1068 pereent in 2010 and 1075 percent in 2030 .

Table 7 presents the WINES model results for the Lower and Upper Reference cases in terms of growth rates for GNP, projected nuclear capacily additions, and energy variables over the projection period of 20) (0) through 2030). (iNP is projected to increase at an annual rate of 1.8 pereent in the Lower Reference case and 2.0 pereent in the Upper Reference case. Detivered energy is projected to increase at an annual rate of 0.6 pereent in the denwer Reference case and 0.9 pereent in the Upper Reference case, Similarly, projected growth in total electrical generallion is 1.8 and 2.0 pertcent per year, respectively. The ration of groweth in electrical gencration on (iNP growth is projected to be 1.0 in both the Lower and Upper Reference cases. The time period for Table 7 has been changed from the 1989 report, and thess the growth rates are not comparable.

The electrical shate of delivered encegy in 2030 is projected to reach, 27.0 and 32.0 pereent in the Lower and Upper Reference cases, respectively. The nuclear share of electrical generation in $2(0.30$ is projected to be 14.5 and 18.8 percent in the Lower and Upper Refirence calses, respectively.

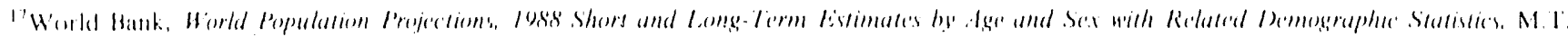
Vu (Washongton, 1) (198k).

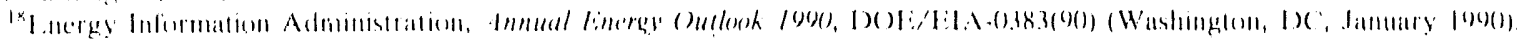

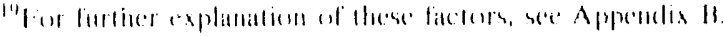




\section{Table 7. EIA/WINES Model Results for U.S. Economic and Energy Growth Rates, 2010-2030}

\begin{tabular}{|c|c|c|}
\hline \multirow[b]{2}{*}{ Varlable } & \multicolumn{2}{|c|}{ Growth Fato (Mean Peroent por Year) } \\
\hline & $\begin{array}{c}\text { Lowor Rolorunco } \\
\text { Caso }\end{array}$ & $\begin{array}{c}\text { Uppar Roloronoo } \\
\text { Carso }\end{array}$ \\
\hline 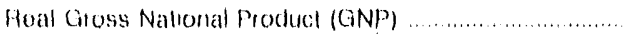 & 1.8 & 2.0 \\
\hline Dolivered Enmegy & 6 & .0 \\
\hline 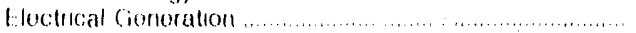 & 1.8 & 2.0 \\
\hline 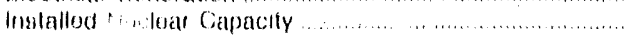 & 1,3 & 2.1 \\
\hline
\end{tabular}

EIA:WINES, Energy Inlomation Adminstralion/Worlel Inlogralod Nucloar Evaluation Syslom. Souro. WINES Modol.

A No New Grders cuse "as also developed. This case depictsa secellation for which the following assumptions alpply.

- Three of the indefinitely defereded units are comb. pleted and become operable.

- All units in the projection are assimed to have aperating lives of 40 gears from the date of issuance of an operating license (current and profected). An exception is Rancho Seco, which is alssumed to officially retire in 1990).

- No newe orders are placed for nuclear plants throsegh 203(0), or these orders that are placed do und result in operahle capacity during the project. tion period.

\section{Long-Term Projections of Installed Nuclear Capacity and Generation}

Profections of installed nuclear capacity and generation for 5-year intervals, beginning in 1990), are presented in Table 8. (Annual projections of capacity and gencration are provided in Tables $I 1$ and 12, respectively, in Appendix 1.). Nuclear capacity is prejected lo grow at annual average rates of 1.3102 .1 percent pre year over the long-term projection neriod (20)10 through 2(1)3()), resulting in capacity projections of 1.34 and 184
GWe in the year 2030 for the Lower and Upper Reference cases, respectively. These projections are shown graphically in Figure 2. The wide variations in the long-term projections shown in this ligure reflect the inherent uncertainty of making such projections. The No Now Order's case projects 6 GWe of nuclear calpacity in 2030). The projections resulting from this caste are very sensitive to the reactor operating life assimption. For exumple, if a 30-year (instead of 4()-year) opcrating life is assumed, operable nuclear copacity is redused to about o GWe instead of 54 GWe in 2020 . Several utilities are hoping 10 extend the operating lives of their reactors by as much as an additional 20) years. If a 60 -year operating life is assumed for all reactors, the amount of nuclear capacity in the No New Orders case remains constant al ahoul loo GWe through 20.3().

The average rate of totat nuclear capacity additions implied by the Upper Reference case, when nuclear replacement capacity requirements are included, averages 7.1 (iWe per year from 2006 through 2030) (Table 9). The rate of capacity additions implied by the Lower Reference ease over the same lime period is about 5.1 GWe per year-adue mainly to a slower anticipated startup of the nuclear supply industry and a slower rate of new plant orders.

Nuclear gencration is projected to grew at annual average rates of 1.6 and 2.5 pereent per year over the period from 2010) through 2(1)30 for the lower and Upper Reference calses, respectively. The No New Orders culse projects generation declining at an annutal average rite of 12.6 percent per year. 
Table 8. U.S. Operable Nuclear Capacity and Generation at the End of the Year, 1989, and Projections for 1990-2030

\begin{tabular}{|c|c|c|c|c|c|c|}
\hline \multirow[b]{2}{*}{ Yoar } & \multicolumn{3}{|c|}{ Capaolly (Not GWo)n } & \multicolumn{3}{|c|}{ Generatlon (Not TWh') } \\
\hline & $\begin{array}{l}\text { No Now } \\
\text { Orlous } \\
\text { Caso }\end{array}$ & $\begin{array}{c}\text { Lowen } \\
\text { rotolonoo } \\
\text { Caso }\end{array}$ & $\begin{array}{c}\text { Uppot } \\
\text { Holonotice } \\
\text { Calso }\end{array}$ & $\begin{array}{l}\text { No Nuw } \\
\text { Oidors } \\
\text { Ciaso }\end{array}$ & $\begin{array}{c}\text { Lowor } \\
\text { Hoteronoo } \\
\text { Caso }\end{array}$ & $\begin{array}{l}\text { Uprom } \\
\text { Holeronco } \\
\text { Catso }\end{array}$ \\
\hline $19 g \emptyset^{\mathbb{c}} \quad \ldots \ldots \ldots \ldots \ldots \ldots \ldots$ & ఏ8 & 98 & y & 529 & 529 & $5 \mathrm{ct}$ \\
\hline 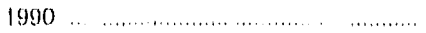 & 90 & $9 y$ & 99 & 541 & 511 & 541 \\
\hline 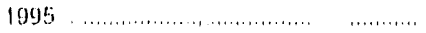 & 103 & 103 & 103 & 558 & stits & 558 \\
\hline 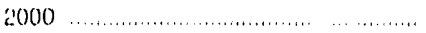 & 104 & 104 & 104 & 572 & $6 / 2$ & 673 \\
\hline 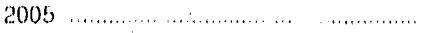 & 104 & ioti & 106 & $50 \%$ & Goss & 608 \\
\hline 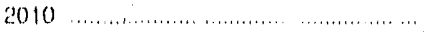 & 100 & 103 & las & 506 & $0: 0$ & 714 \\
\hline 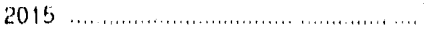 & (3) & $10 ; 3$ & 124 & 409 & 506 & 717 \\
\hline 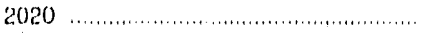 & 54 & 116 & 146 & $3 \%$ & 694 & 875 \\
\hline 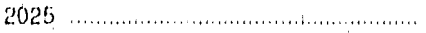 & 28 & 125 & 165 & 166 & 776 & $1,0,4$ \\
\hline 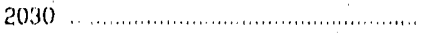 & 6 & 134 & 164 & 40 & 851 & 1.171 \\
\hline
\end{tabular}

" Capacily valuos are based on nol summol capatillty ratings.

b Capacily valuos are rounded to the nearost gigawatt. Genoratlon valuos are rounded lo tho noarost torawallhour.

- Actual.

Sources: Capaolty Data-Enorgy Intormation Administration, Fom ElA-860, "Annual Eloctric Cionotalor Foporl" (1980) Post-2010 Capaclty

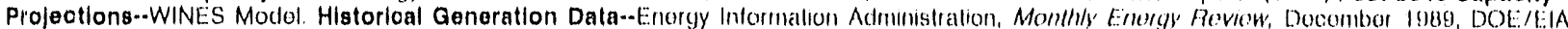

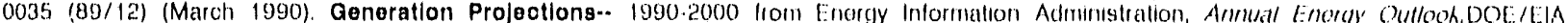
$0383(90)$, January 1090 and Intomalional Nuclaar Modol (1990).

Figure 2. Domestic Nuclear Capacity, 1982-2030

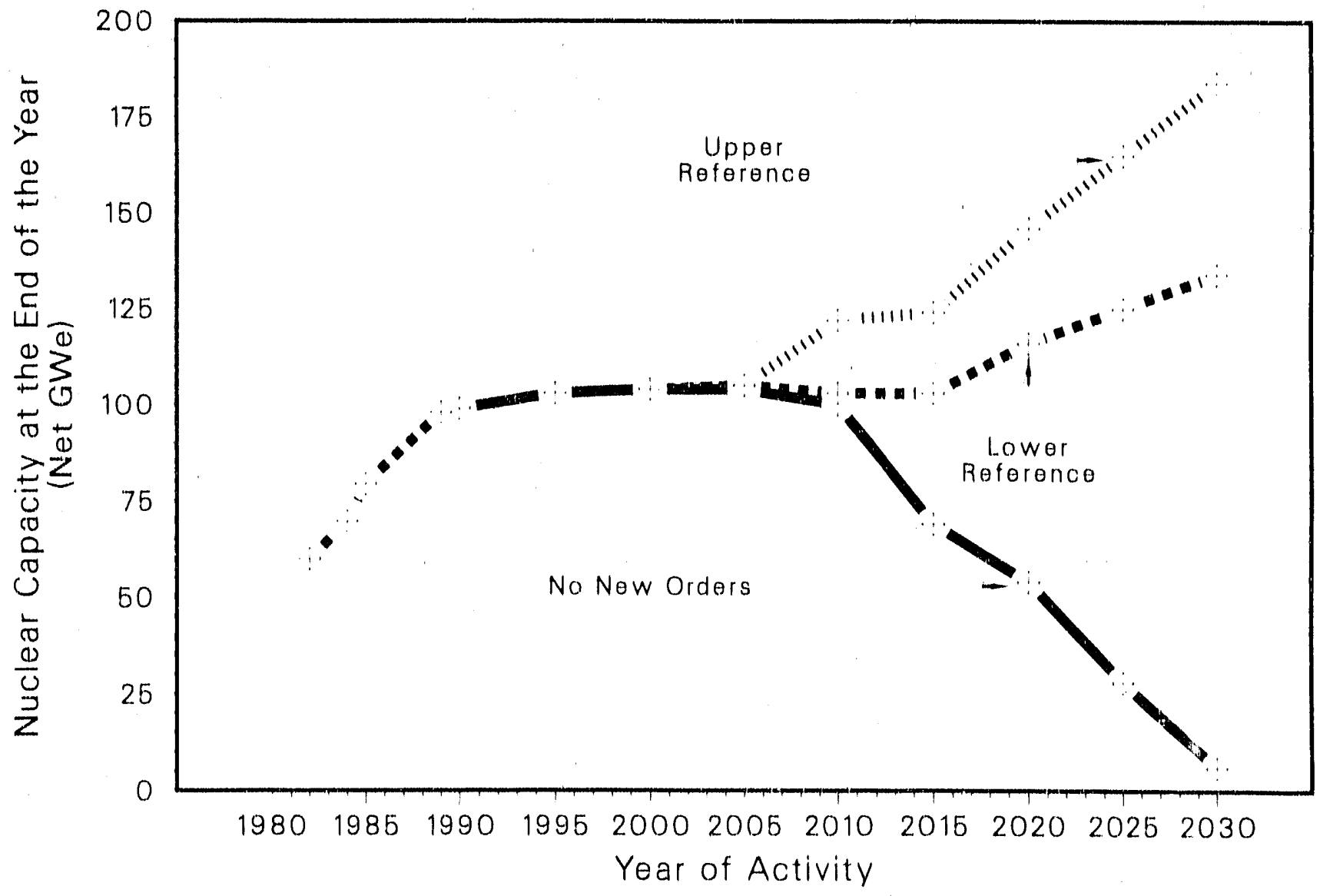

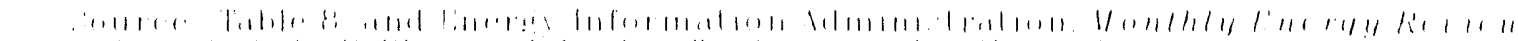

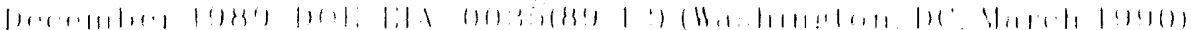




\section{Table 9. Nuclear Capacity Bulld Rates Implled by Projections} (Net Glgawatts-Eloctric per Year)

Case
Lown foldencel

\section{Sensitivity Cases}

\section{Nuclear Plant Life Extension}

Nuclear power plane life extension (NUPlolis) refers (a) the extension of the eprerating lifie of commercial power plants by the renewal of their operaling licenses

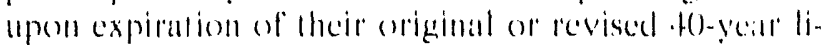
cense Latm."

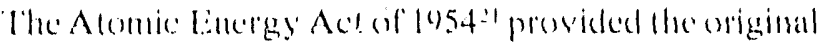
sed of regulations regarding commertedal nuclear power plant licensmit, which included setling a stattutory fimit

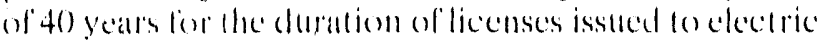
utilitices thall operate commenereial nuclear plants. The selection of a 4 (1)-year limit was not based on the antice. ipaled usefinl life of the nuclear plants but rabler on financial and exomomic consideralions."

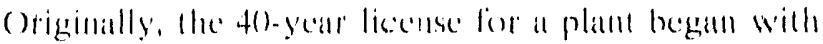

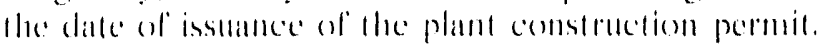
In 1982, however, he: Noclear Regulatery Commission (NRC) determined that plants eomld be licensed fior 40

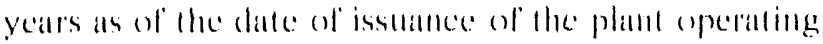
license, and this became standard pratedice for the li-

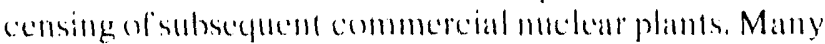
older units licensed before this revision have since been granted licensing adjustments or extensions to allow

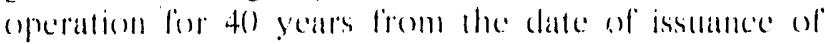
their operatting license. Most of the remainimg monts are: expected to follow suit, and as staled previonsly, this is assumed for linese projections.
As af Decominer 31, 1989, a folal of 110 U.S. commoner-

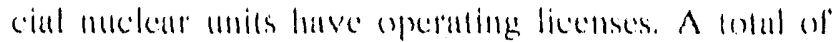

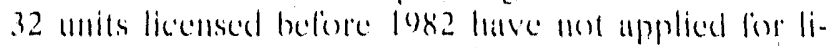
cense adjustments lo recerese the comstruction time and allow a full-ferm speraling license of 40 years." If" dhese units ane granled lheir corresponding license adjustmonls, expination dates will shift lo later years, as shown in liggure. 3 .

Fonr mits (1)resden 2, (oyster Creck, Palisades, and San onolie 1) have provisional operating licenses and

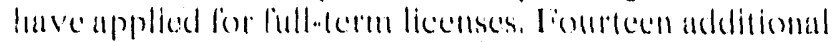
commercial maclear units formerly licensed le operale

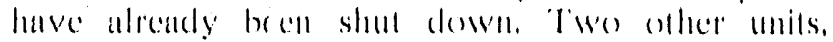
Shippingport and the Hanford-N reactor, were never licensed.t.

The Atomic Energy Act explicilly permits the license renewal of eommercial nuclear plants; however, the regulutory reguirements for the scope and content of license renewal applicalions, the criteria for covaluating stech applicalions, and the procedures for submilling and reviewing hem have not been defined.

The NRC stanted a program to develop a regulatory procesis for license rencewal in lo86 with the issuing of a ferleral Register nofice reculesting public commonems on the license renewal policy development effort and indicating its intent ar develop a commission policy statcultellt."

In an August lo88 publicalion the NRC expressed its intention for move direcelly to rulemaking on a "slightly acceleraled schedule" raller than issuing a policy statement prien fo a rule as previously planmed."

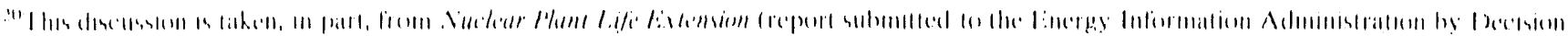

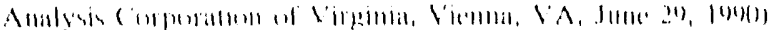

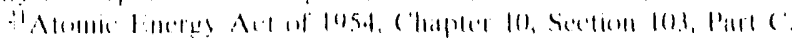

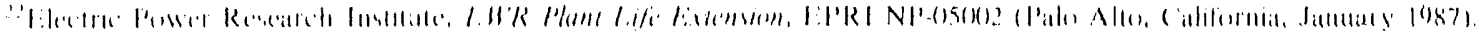

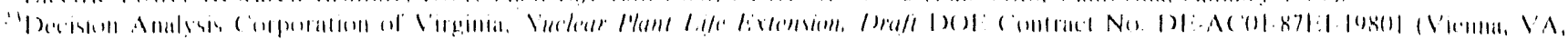
Apwill

$\therefore \mathrm{ll} / \mathrm{d}$

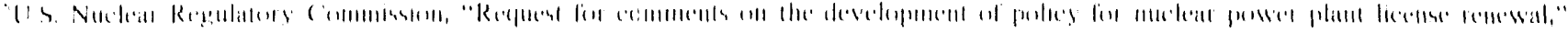

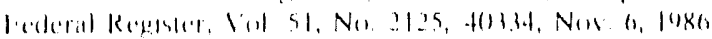

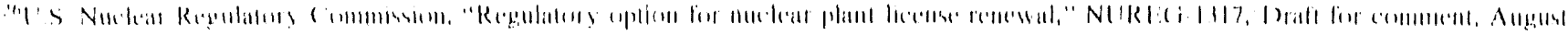
$19 \times k$
} 


\section{Figure 3. Nuclear Capacity Retiring by Year of License Explration}

20

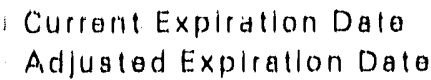

15

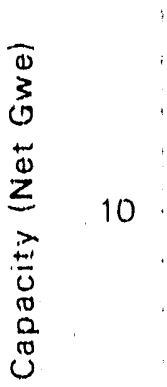

6

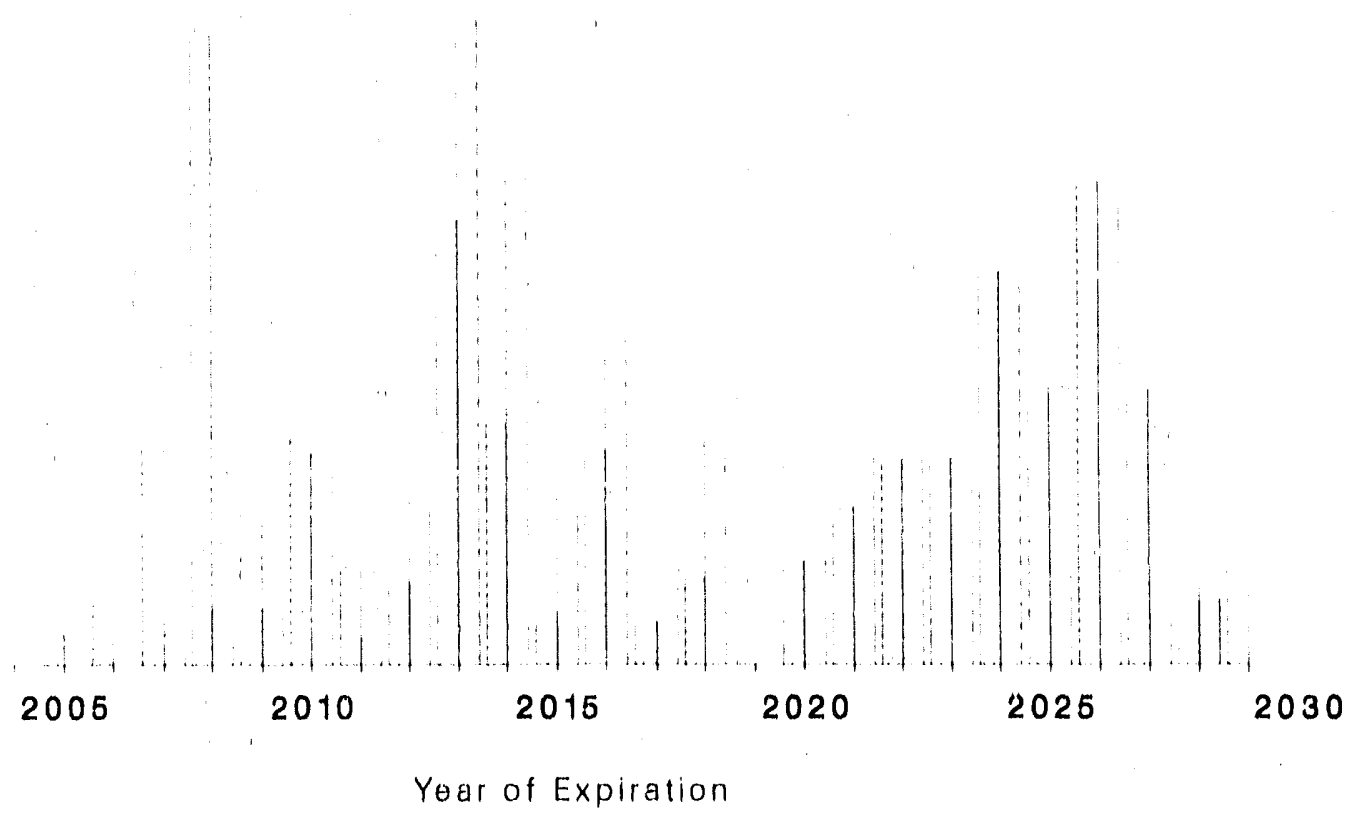

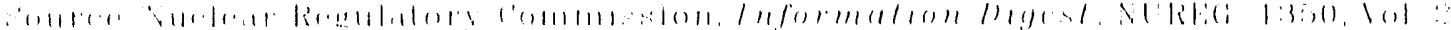

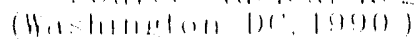

In July I90(), the NRC published the proposed rule for comment." Publicalion of drafl regulallory guidance is expected lo begin in micl-100) with review of the lead plants license renewal applications. Completion of final regulatory guidance is anticipaled in early 1904 , sherelly after the completion of the lend plant license renewal applications review.

Electric utility industry elforts tomanyac life extension, began in 1078. when the Electric l'ower Resenteh Institule (FI'RI) undertonk a series of studies which suggested that extending the aperation of corrent anits be yond their nominal 40 year license lerm was both ter:hnically feasible and exemomically atractive.

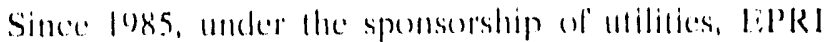

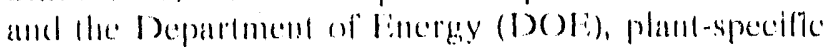
studies have been in progeress fo identify and evaluale polential eritiont components, systems, and silfuctures that wenlel inllenence life extension decisions.
In 1988, the nuclear industry ereated the Nuclear Management and Resomeses Comncil (NUMARC) NUPI.EX Working Group to coordinnte mtility support for plant life extension and lo serve as lle mility inlerface with the NRC management. The group entphasis is on developing recommended positions concerning license renc:wal policy, regulallon, procedural fromework, grudelines, criteria, and timing. In ackdition, the industry has been undertaking studies fo evaluale the aging of hardsatre and its effect on plant reliability and silicly.

Following the plant-specilic studies, the industry and DOF: have indiuted the lead Pants Project. This demomstration project is intended lo support lhe NRC."s development of a license renewal presesss and confirm the viability of the appreach through lead plant applications reviews. The lead plants are Yankere Alomice likedrice Company's Yankee Rowe and Nomberns Stales Power's Monticenllo. 


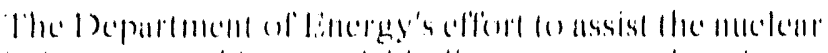

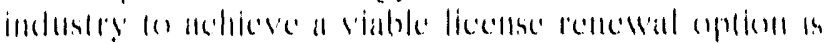

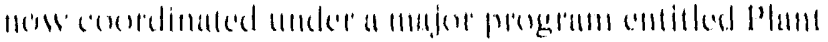

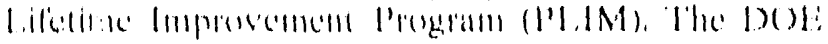

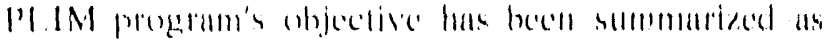

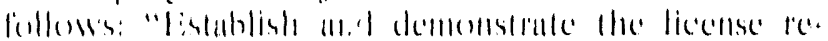

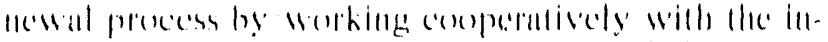

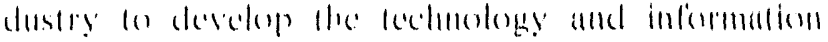

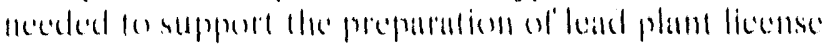

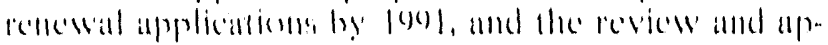

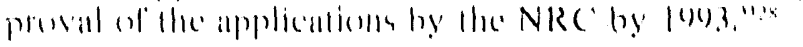

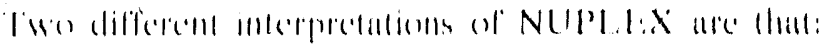

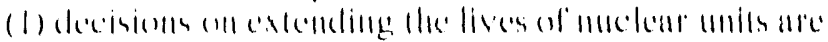

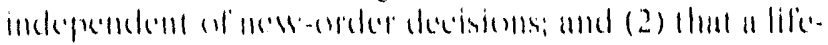

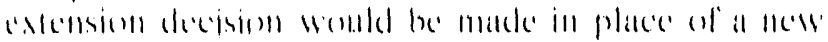

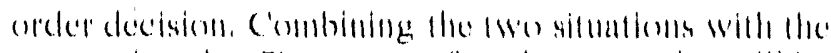

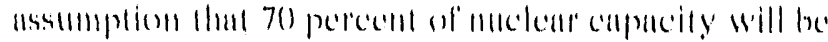

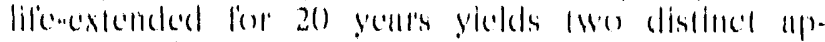

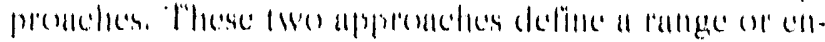

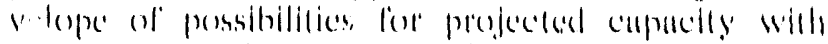

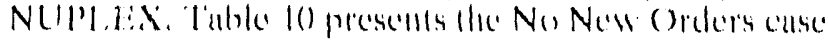

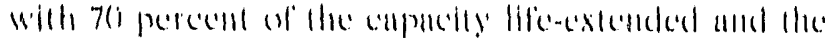

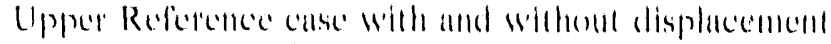

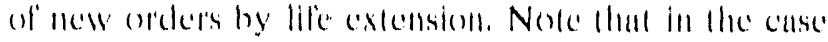

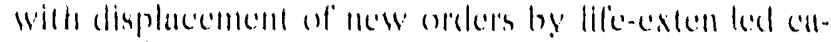

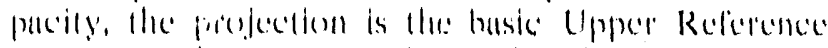

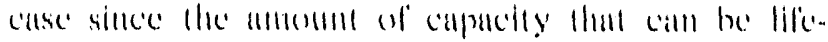

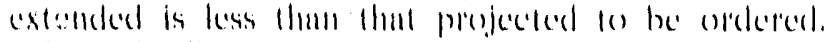

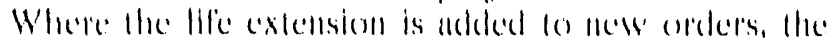

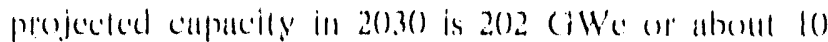

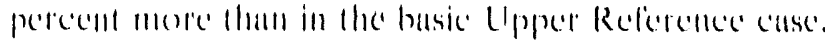

Table 10. U.S. Operable Nuclear Capacity Assuming 70 Percent Plant Life Extension 1990-2030 (Nol Gigawalts-Eloctric)

\begin{tabular}{|c|c|c|c|}
\hline \multirow[b]{2}{*}{ Yoar } & \multicolumn{3}{|c|}{ Cupaolly (Not aWo)" } \\
\hline & $\begin{array}{l}\text { No Nrow } \\
\text { Ordors } \\
\text { Cielste }\end{array}$ & 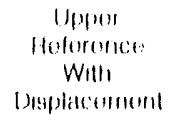 & 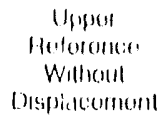 \\
\hline $199(1)$ & $! ! !$ & $9 !$ & !) \\
\hline lifin, & 101.1 & $10: 1$ & 101,1 \\
\hline (1)ा1) & 1014 & 1014 & 104 \\
\hline ציו1) & 10.1 & $10 t$ & 106 \\
\hline (1) & 111.1 & 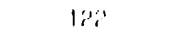 & 190 \\
\hline :था। & !10 & 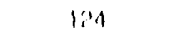 & 141 \\
\hline (1): & Hi. & lali & 113 \\
\hline : & 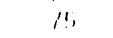 & 11i! & $13 i$ \\
\hline जiln & 11 & 1814 & $\therefore(0)$ \\
\hline
\end{tabular}

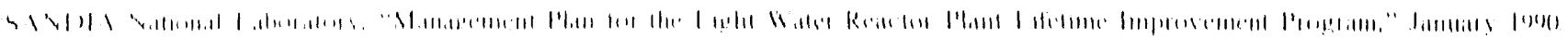
$1 \cdot 4$ 


\section{Comparison With Other Projections}

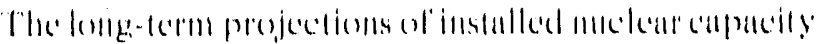

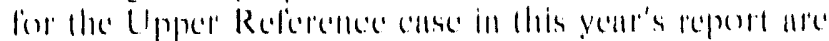

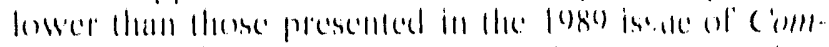

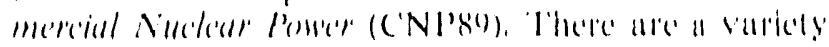

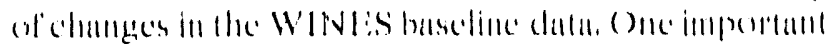

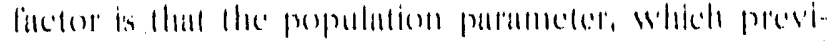

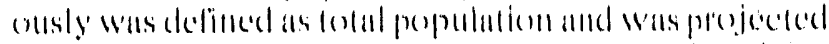

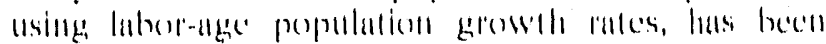

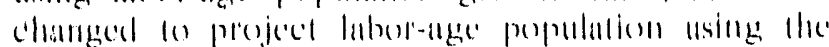

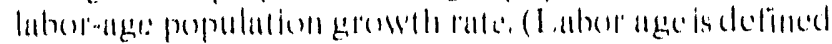

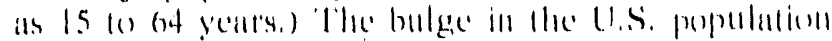

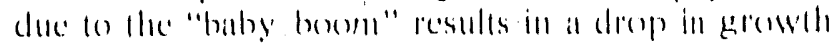

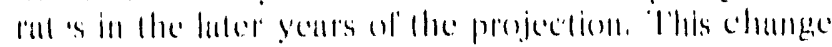

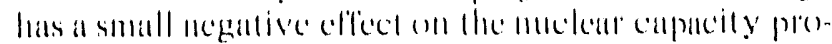

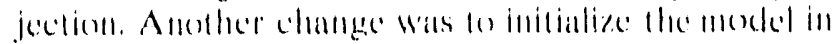

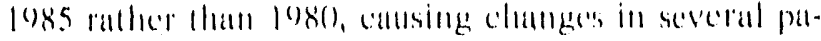
ranteless. Typically, one ol the mone semsitive param-

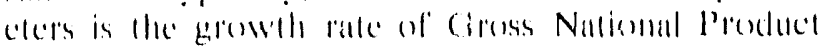
(ciNl). (White this is a model resull, WINIS is colli.

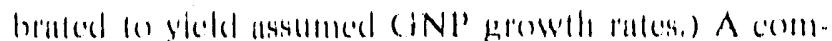

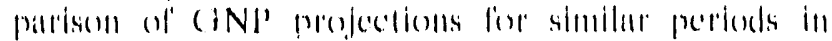

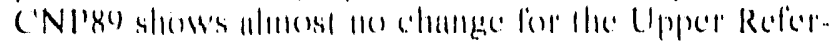

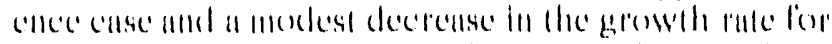

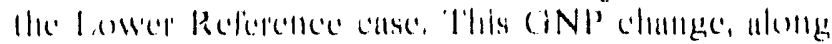

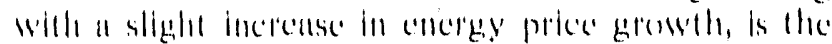

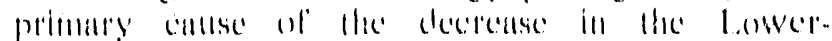

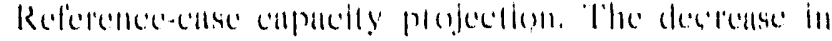

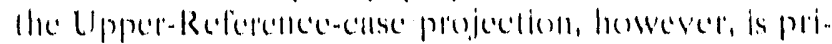

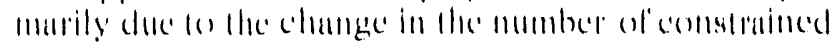

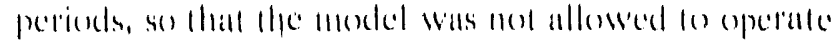

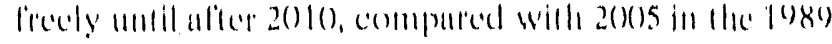
repertit.

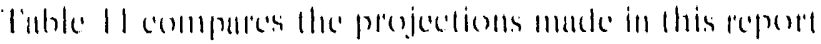
and in the loger report will similar foreconsts and projections prepured by allew organizations. Cicmetally,

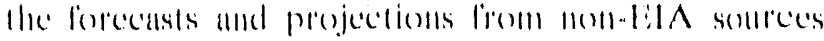

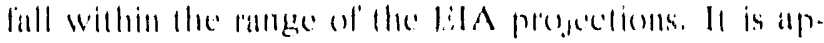

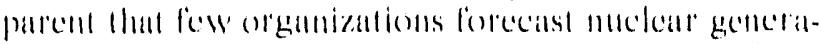
lion and capacity beyond Ile year 20()). The DRI forecust assumes that no new muclear plants will be built

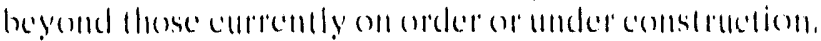

Table 11. Comparison of Projections for U.S. Nuclear Capacity at the End of the Year, 1990-2020

\begin{tabular}{|c|c|c|c|c|c|}
\hline \multirow{2}{*}{ Source } & \multicolumn{5}{|c|}{ Capaolfy (Not $\left.Q W_{\theta}\right)^{a}$} \\
\hline & 191010 & $199 !$ & $\therefore(0)(10)$ & 2010 & 200 \\
\hline \multicolumn{5}{|c|}{ Energy Information Administration } & \\
\hline No Now (neders liatset & 114 & 103 & 104 & 100 & 54 \\
\hline I owor fonlerence lialse & $(19)$ & 10,3 & $1(14$ & $10: 1$ & 116 \\
\hline 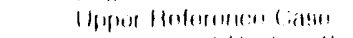 & 3 & $10 ; 3$ & 104 & $1 \%$ & 146 \\
\hline \multicolumn{6}{|l|}{ 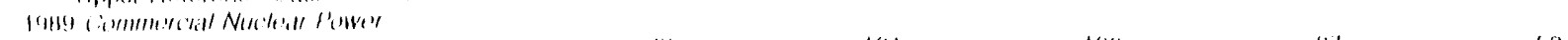 } \\
\hline 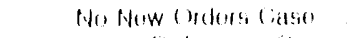 & 90 & 101 & $10 \%$ & 97 & b? \\
\hline lewer Botenonces calse. & 100 & $10: 1$ & 104 & $|11|$ & 123 \\
\hline 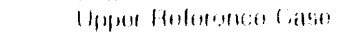 & 1111 & 105 & $10 \%$ & 136 & $133^{\prime}$ \\
\hline DAI" & 101 & 106 & loti & 100 & \\
\hline NERCi & 101 & 104 & & & \\
\hline NAC' & 1011 & 104 & $101 \mathrm{i}$ & 104 & \\
\hline NEI & 10,14 & 109 & $10 ! 1$ & & \\
\hline NUKEM' & $10)_{c}^{\prime}$ & 104 & 1114 & & \\
\hline WEFAU & ()H & $110 ;$ & 101.1 &. & . \\
\hline
\end{tabular}

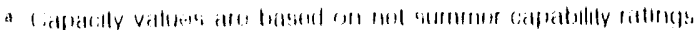

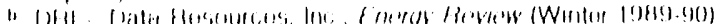

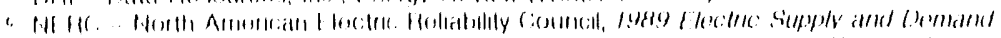

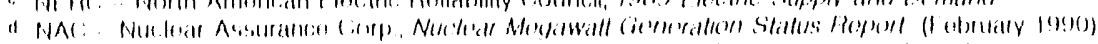

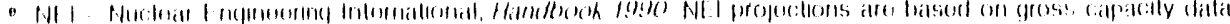

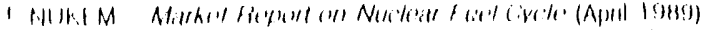

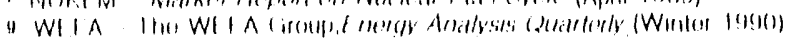




\section{Institutional and Technological Developments}

\section{Iritroduction}

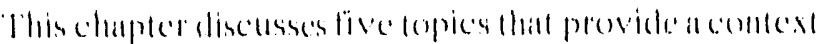

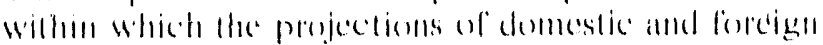

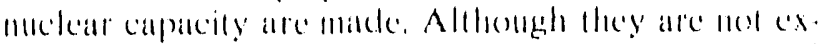

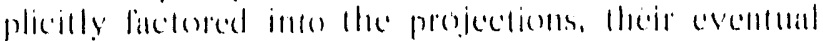

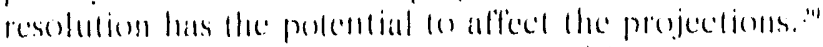

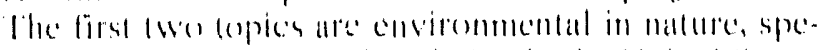

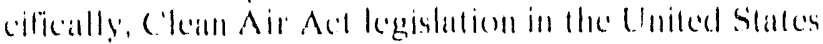

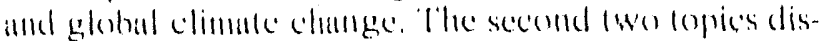

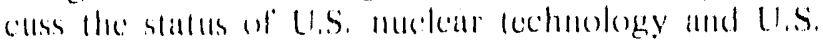
nuclear powere plant decommissioning cost estimates. The firth topice is a discossion of ihe inlermationalizalion of the meletear powere industry.

\section{Environmental Issues}

\section{Clean Air Legislation}

For the linst lime since patsinge of the Clean Air Act Amendmemls (P.1. 95.95) in 1977, hoth (hambers of the U.S. Congress have passed wide-ranging legislation on air pollution. The bills, while not iclentical, are similar in aim and structure. Buth hills contain sections

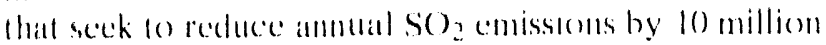
lons from log() levels and anmual No), emissions by 2 million toms from llic level cenrently projected for 20$)(0)$

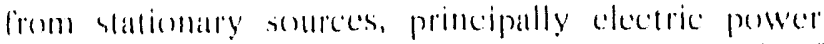
plants. Another key feature is the permanent limit of 8.9 million fons per year of $\$ \mathrm{SO}_{2}$ emissions from electric genemating plants after the year $2(x)$ (). These reguire. ments condel indirectly concourage a new assessment of moclear perwer produstion in the Lhited Stales.

The senale hill (S. 16.30) was passed in spril log(). The provisions in leitle IV, "Acid Deposition Comtrol," are

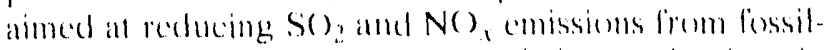
steam plants. The hill recpures comissions reductions in

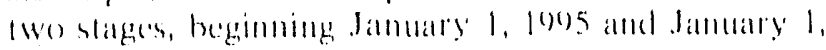

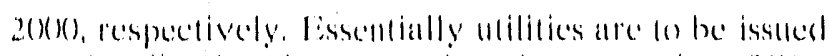
permils allowing llom lo emil a geiven quantily of $\mathrm{SO}_{2}$

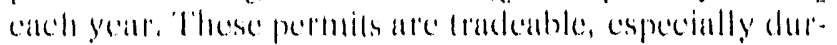
ing the secomel phuse. The momber of permits bisited of

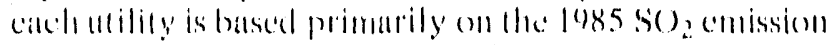

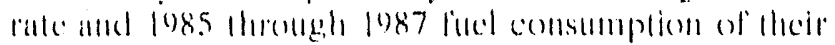

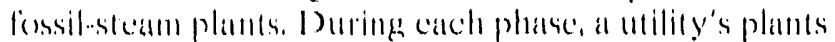

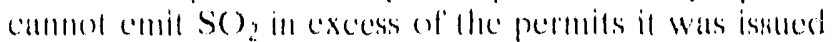

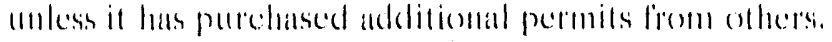

The House bill (11.12. 3(130) passed in May lou() is very similat in its treatment of electric power plants. As in the Semale bill Tille $V$, "Acid Deposition Comlrol," He Honse bill repuires emissions reductions in lwo stages. However, in the Honse bill the stages begin one year later than these in the senate bill, December 31, fogs and 1)ecomber 31, 2()()), for phases I and II, respectively. Whe Senale bill uses the reduction expected lo oceur between Janluary 1, 1995 and December 31, 1095 as boums permits that are distributed to certain units. A second difference is that the Honse bill creales two landing regions (East and West) for existing plants, but he semale bill has one regions. A Conlerence Commillee between the Homse and the Senate has been formed to work ont the differences between the lwo hills. Ilowever, becalese the alcid rain secolions of the bills are so similat in their objectives, it is expected that there will nes be major changes in the proposed realment of power plant emissions in ihe compromise hill.

Through 200(), electrice utilities have several options

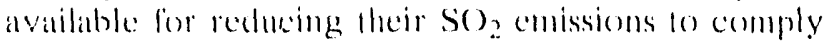
with the allowance constraints. The Horee major oplioms are decereasing their use of unils that use medium (1) high sulfur coal willoul pollution comlrol equipment, switching units asing high sulfur conl fol low sulfure comb, and retrofilling plants that use high sulfur conll with fluc: gus desulfurizalion equipment. Utilities will make use of all three options to minimize the cost of complying with the allowance comstraints. The re. gions that will be affected the most as milities either

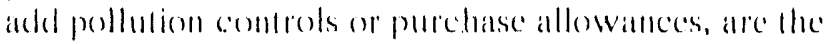
Midwest and Ho Semthenst. These alde also the same regiens that corrently have the grealest ambentuls of muclear capacity (sce Vable 4, p. 7).

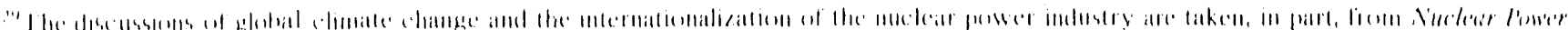

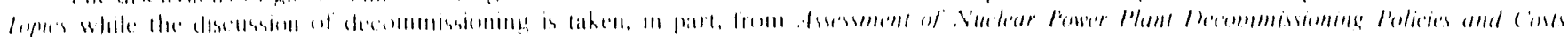

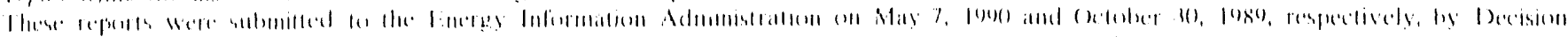

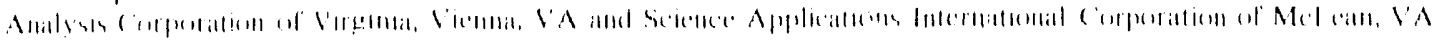




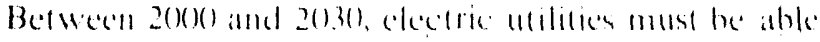

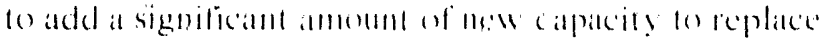

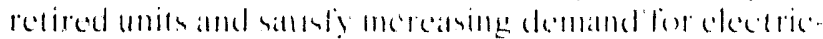

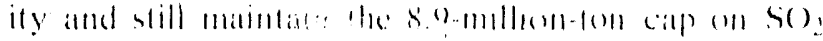

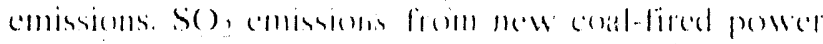

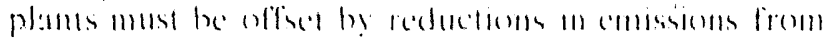

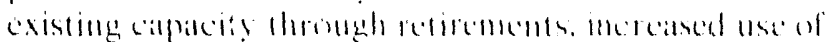

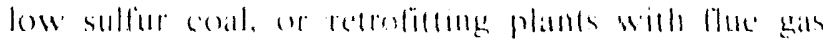

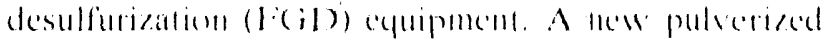

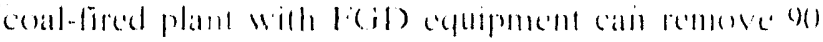

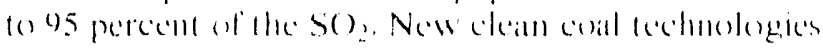

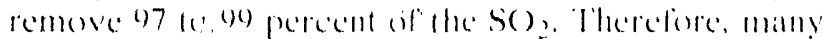

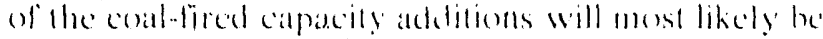

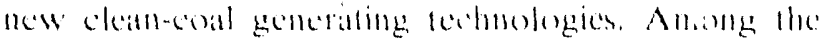

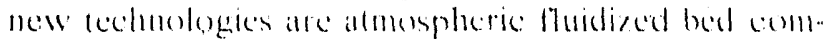
bustion units (AFB), pressurized fidudaed bed eoms. bustion units (PlB), integrated gasification combinced

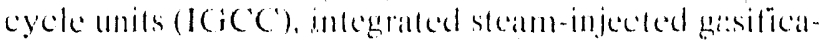
tion units (ISTlei), and fine cells, Howerer, Here is uncertainty ahout the costs, envirnmencolal impolcts, and performance of the new technologices now undes development. Utidies may recvaluate the notedear option as an altermative fo coal for baseload gencration.

\section{Global Climate Change and the Future of Nuclear Power}

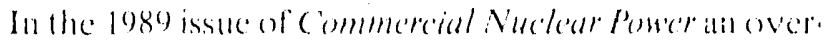
view of the emvirommental and energy policy in 21 eomintres was provided. At that time, mo approved legislation addressed both global climale change and energy policy responses. It was suggested hat, whth the exception of a few envirommentally progessive coumtries (the Netherlands, Sweden, and West (sermatly), global climate batmge concerns would mol significantly affect fued elonices, especially in the short term.

The findings in that repert continue on be supported. The international policy climate is becoming linther delined. Allhough several envirommentally progeses. sive combries have made recent stalements regarding energy responses of elimale change, these countries have relatively small genwht in electricily demand. thereby reduesing the signilicance of their fuel chosce decisions on workiwide nuclear capacity.

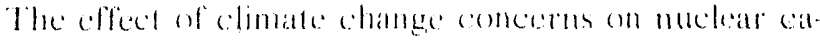
pacity cammen he lably detemumed until response strat. egies arechearly defined and then implemented haremgh

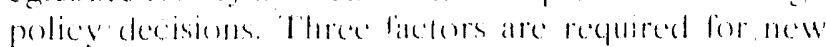
nuclear capareity: (1) acceptatre of mackear power, (2) growih in electrietly demand, and (3) finateing for

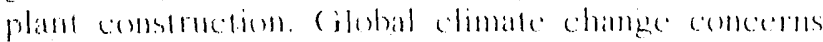
may affect each of these firctors.

\section{Background}

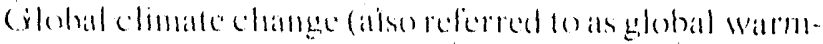

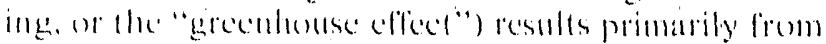
lhe combustion of organic malter and ontere

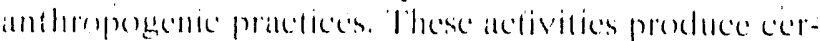

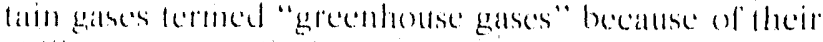

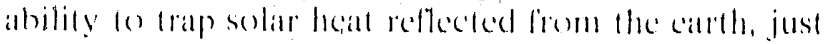

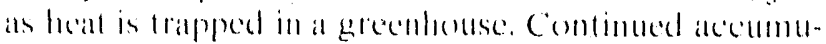

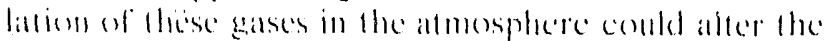

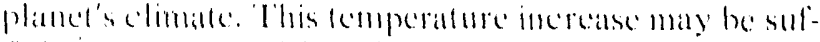

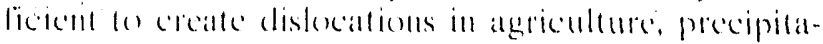
lion palleriss, pepulation distributions, forestry, fishong. and hoalth.

A manjor difliculty for policymatiers adelessing climale change is scientific uncertainly regarding the timing and magnitude of chmate change. Opindons differ within the scichtific commmonty about the calpacity of gacenhouse gas sinks such as the occall, possible atmosplerice cooling effects from cloud cover, and biofecelback as a resull of increased almospheric callbon dioxide and higher temperatures. These uncertainties prevent clear defintion of the impace of elimale change on seciciy: thus, it is also monclear fowhat extent policy respenses are required. The benelits of government action on climale change are as ill defined as the costs of inaction. Sciontifie resolations of climate change uncertainties will take years if not decades. However, there is growing public opinion that increased climate change risks als a result of inaction are unaceptable.

The discussion of policy responses fo climate change centers on the emission of the five principal greenhouse gatses: carbon dioxide (C() $)_{2}$, nitrous oxide $\left(\mathrm{N}_{2}()\right)$ chlorrinated thionocarbons (Cles), ozone $\left(\mathrm{O}_{2}\right)$, and methanc $\left(\mathrm{CH}_{4}\right)$. The single largest eontributor to the proliferation of greconhouse galses is the combustion of fossil fincls, chichly coall.

\section{Nations Most Likely to Unilaterally Alter Nuclear Policy}

There countries, The Nellucrlands, Sweden, and the federal Republic of Commany (FR(i), have the greatest pofential to alter milaterally muclear encegy policy in response to climate change concerns. Chatacteristics of this group are: (1) they are among the most progeressive comntries in implementation of stringent stationary sollece air emissioms standards; (2) they have begun development of encegy policies in response we climalle change concerns; (3) they have both the sechondegy and linancing for nuclear power: and (4) hoey have

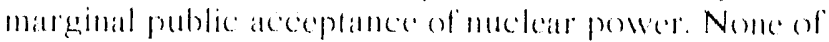

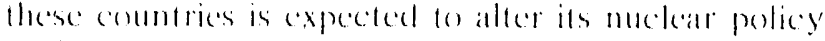
in the carly forects. 
The Netherlands, Sweden, and the FRe are among the most progersive colmotrices in their treatment of stationary emission sources as a result of emvirommental considerations. Continumg in their hostorical patterns, these same three countries have been very active boll nationally and incernationally in addressing climate change. In addition to United Nations-related policy discossions of ghlobal climate change, lhese countrices have been very atedive in the promotion of parallel pol. iey negentiations such ats the Declaration of the Hague (1989), lle Minsterial conference at Noordwijk (1989), and the Bergen (onference (1990). In view of the mote envirommentally progressive mations, if the U.N. Inlergevermonental Pancl on C'limale Change (HPC() process (sece following section for discoussion of this process) fails to promole sufficiom policy responses to climale change, then the parallel poticy process may become mere signifieant. The rote of the Netherlands, sweden, and the fRe in parallel penticy negotiations furlher suppots the resolution of these contries to address climale change with poley responses.

\section{Multilateral Policy}

The IPC is the single most important intermational forum for multilateral discussions of elimate change. 11 was established in lose by U.N. (icneral Assembly Resolution 4.3/5.3 "10 provide internationally coordinated scientilic assessmems of the magnifude, timing and potential envirommental and socio-ecossomic impact of elimate change and realistic response strategies." the IPCC operates under the auspices of two L.N. bodies, the World Meteorological (organization (WMO) and the Lniled Nations Emvirenment Programmo (UNIIP).

The Hece is divided infor these working groups: (1) science, (2) impacts, and (3) response stralegies. The third group is of most interest for this discussion and is chatred by the United states. This group tries to assess the magnitude of future greenhouse gas emissicass. the impacts of changing techolologics, greenhouse gas solleres and sinks, adaptations 10 climalle change, strategies io reduece emissions, and social and economic implications. Additionally, this group is to consider kegal mallers, including the appropriateness of a climale convention of other forms of infermational cooperation to address posential elimate change

The IVCC"s Response Strategies Working Ciroup it expected lo reconthend an international policy process for deating with climate change. Its fimal draft report is lo be presented at the lementh Plenary Session of the Ifre scheduled fo men in Sundsvall, sweden, in $\mathrm{Au}_{1}$ gust loue The IPCe dratt action plan will be presented at the U. N. Ciconcral Assembly in Seplember and at the
WMO-sponsored Second World Climate Conference scheduled for November.

Alte, reviewing the IPCC recommendations, the U.N. Gencral Assembly is expected to defermine whoshould he charged with the task of drafting a global climate change convention for presentation at the 1092 lI.N. Conference on bnvironment and levelopment. It is expected the (icneral Assembly will, to a latge extent, follow IPCe recommendation on the policy process for multilateral address of climate change, Dralt re. ports of the IPCC Responsc Stralegies Working (iroup have leanced toward a two-step policy process similar 10 that used to adeleses ozone depletion, the lirst global envirommental issue tr recerve muldilateral policy attention. The policy process for respontse to the isste is thenght to represent a precedent for luture adsleess of global envirommental problems, including climate change. The lirst step in this process was the establisho. ment of lle Vienna Convention for the Protection of the Orone Layer in 1985. This convention see down a formal statement of commitment by govermments be futureaction with regard to ozonc depleting chemicals. In 1987, these commitments were translated into re. yuirements for reductions of specific chemical classes in the Montreal Proterest on Substances that Deplete the orone Layer.

The 1902 U.N. Coriference on Enviromment and Development is likely a use a framework on climale change similat to the one used at the Vienna Convention: 'The isste of whether to set numerical goals for emissions reduction will be a key negetiating point at this conference. For aceeptance of this comvention among developing nations steh as India and Brazil, it will probably include statements regarding, the promotion of lechnological and financial assistance lo doveloping matrons for sustainable development. " "Sustainable development" is an overriding political concept at international forums addessing global envirommentat enncerns. The World Commission on Environment and Development defines "sustainable development" as devedopment which meets the needs of the present withoul compromising the ability of future generations (1) meed thedr own needs.)

The second phase of the multilateral policy process will either develep separate agreconents for each of the major greconhouse gatses or a comprefuensive multilatcral agrement on many different specific geals.

At international mectings and conferencess, such as IPC 'meetings and the Torento conference on the Changing Almosphere (1988), bricf statements have

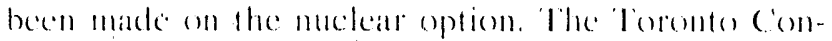
ference Siatement sugerests at "rothinking" of the moclear eption. At hese conlerences, mations stech as Sweden, Norway, and the Nelherlandes guestion the acceptability of the nuckear uption on safoly grounds 


\section{Potential Impact of Glcbal Climate Change on Nuclear Power Financing in Developing Nations}

A multilateral policy statement acknowledging the nuclear option will not, by itself, increase the ability of developing nations to obtain linumeing for nuclear development. Howevere, such a statcoment could provide: an indication of the acceptability of the matroff' befween greenhor se gats comissions and notelear power with its associated problems.

\section{Nuclear Power Lending Policy at the World Bank}

The primary multilateral lending institution is the World Bank. This institution was set up under the U.N. to aid developing coummies. The World Bank hats granted loans for power plants but never for a nuclear power plant. The Bank's policy is founded on least-cost principles. However, eoncerns over the adequacy of

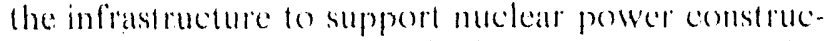
tion and operation in develeping conuntries may also effect the Bank's lending policy.

If the environmental impacts of hessil plant construction are fully intermalized, it is possible that nuclear power will become morecomperitive with other power sources in cost comparisoms. An indication that the World bank may be giving more weight to emvirenmental values is seen in the recent development of an organization within the World Bank specifically for the purpose of promoting natural gas rather than coal and oil in developing mations. The impetus for development of this organization stems from criticisms that the Bank is not denge enough fo counter the threal of climate change.

The Bank has estahlished a liasson to the IPC process. and is currently preparing an internal policy guidance paper addressing climate change concerons. In the future, the Bank will likedy address $\mathrm{CO}$, stabilization further with the primary emphasis likely to be placed on efficiency improvements and hiomass development. Traditionally, funding has been predominanlly for proven power systems with relatively little lending for new technologies,

At the present time. the World Bank is not expected to aller its kealst-cost policy. Bank representatives assert that in many countries the large cost differential between nuclear power and other entergy altermatives places a heavy burden on the nuclear option. If a mulsilateral policy were develoned that ackinewledged a nuclear component or climale stahilization pregrams. the Bank would likely adapt its policy to reflect international consensus. The Bank would be anditicly, however, waller courrent policies on its ownth.

Regardless of lending policies, it is expected that eligi bility for nuclear development loans and technology would remain eontingent upon the borrowing nation signing an International Atomic Energy Agoncy (IAEA) Sufeguards Agrememt. These agreements atlow for IAEA inspection of nuclear facilities and fucel cycles to confirin that me products of the plant ate available for mi!itury purposes.

\section{Summary}

No mition is likely to respond to climate change with nuclear policy alterations in the next few years. Several nations (the Netherlands, Sweden, and FR(i) appear to be more likely o aller muckear policy unilaterally as at response to climate change. This ansessment is hased largely on the historical environmental pregressiveness of these countries with iegard to stallomary source emissions and their current address of climate change. However, each of these countries has, at hest, marginal acceptance of nuckear power.

Given that in the next deceades, a latge ambent of new clectric capacily will be comstrteted in developing nations, incerasing nuclear power financing to these conultries could be a significant effect of climate change concerns on worldwide melear: capacily.

\section{U.S. Nuclear Industry}

\section{U.S. Nuclear Technology Review}

This section discusses the new alledear reaclor lechnologies that are emerging as candidales for commercial use in the United Statles. The landing candidates for new orders in the sarlicer part of the projection period are large $(1,()(x)$ ) $M W($ ) and mid-sized (6)() $\mathrm{MWe}$ ) light-water reactors (LWRs). The larger units incorporate changes to existing designs; the smaller units incerporate passively safe design features. Tiwo nonLWR technologies are expected to be commercially avalable for new orders later in the projection peried. These are the helium-cosled modular highemperature gats reactor and the sodium-coneled liguid metal reactor.

\section{Light-Water Reacters}

ligh-water reactors use ondinary water als al coolant. These designs are by far the most common in the workt, lementing the basis of operations in every major nuckar power generating country except Cantada (heavy water) and the United Kingdem farbon dioxide and heliums). 
Currently, most of the eommercial effort is on changes to today's l.WWR. These changes fall into lwo primary groups: (1) evolutionary design changes to large, conl. ventional boiling-water reactors (BWRs) and pressurized-water reactors (PWRsi) and (2) major syslems simplifications, use of passive safety systems and extensive modularization, and prefabrication (facililated by their smaller size), for mid-sized BWRs and PWRs. Most of the design work is in the United States and Japan.

In June 1989, the U.S. Nuclear Regulatory Commission (NRC) staff concluded that the General Electric Advanced BWR (ABWR) design sattisfactorily addressed concerns over severe accidents. Final Design Approval and Certification was expected by late 1991 lo early 1992. The Westinghouse Advanced PWR (APWR) was expected to receive final design certification in 1993. This design is an advanced version of the most recent Westinghouse PWRs, such as Callaway and Wolf Creek. Scheduled just behind the Westinghouse design for final design certification by the NRC is the Combustion Engineering System 80+, based on the System 80 design of the operational Palo Verde units. In June 1990, the NRC voted on a review process that could result in up 10 a 2 -year delay in these design certitications. Another uncertanty that could lead to a delay is the level of cesign required for standardization.

Still evolutionary but less so than the $1,0(0)+\mathrm{MWe}$ reactors are the mid-size advanced reactors. These reactors, generally $600 \mathrm{MWe}$ or less, are at the detailed design stage. The reactors feature a modular nuclear plant design that can be built within 4 years (not including licensing), using factory-produced construction modules that will be assembled on the site of the nuclear power plant. The passive safety system uses natural physical forees--such as gravity, convection, evaporation and conclensation--10 cool the plant in the unlikely event of an accident. The relatively small capacity of the reactors, increased design margins, and large supplies of passively invoked and gravity-fed emergency cooling water provide a higher degree of passive safely. In 1990. DOE awarded Westinghouse and GE $\$ 50$ million cost.sharing contracts for design and development work on the APGo() PWR and the Simplified BWR (SBWR), respectively. It is anticipated that the NRC will issue final design certifications for the $A P B O()$ and the SBWR by 1998. Commercial prospects for these units await further expressions of utility interest.

\section{Gas-Cooled Reactors}

The commercial modular high temperature gas-cooled reactor (MHTCIR) being developed in the United States is a muclear power system capable of providing clectricity and process heat. It uses a graphite core, refractory-coaled particle fuel, and helium gas as the coolant. This unique system can potentially provide sufety, investment, and environmental protedion margins through use of natural phenomena and properties. A major objective of the MHTGR is to preclude the need to evacuate or shelter anyone beyond the site boundary becatise of an accident.

The proposed commercial design eliminales the eonventional containment structure found in LWRs. Instead, the fuel particles function as contamments for the fission products. Also, the refractory-conted fuel can relain fission products under even severe eondi. lions.

With the MHTCR design, shutdown heat can be removed from the eore by radiation to the ground without rellance on a heat removal system that could fail, removing the potential for the fuel to overticat.

The department is funding design and development of the commercial MHTGR. The Preliminary Safety Evaluation Information Document was presented to the NRC for review. Based on this design documentation and a series of comprehensive technical meethes, the NRC issued a draft safety evaluation report in February 1989, that is being factored into the Department's plans for continued development of the concept.

The commercial MHTGR is locusing o: the development of improved low enriched uranium (LEU) fuel fabrication processes, advanced methods of assuring the quality and performance of the fuel, proving the inherent heat removal capability of the design, and proving the safety features of the design. Efforts are underway to evaluate L.EU fuel performance and fission product hehavior, and to develop, verify, and validate analytical models and codes.

The Department has cooperative international MHTGR technology development programs with the Federal Republic of Germany, France, Switzerland, and Japan in the areas of fuel performance, physics, metals, graphite fission product behavior, safety and analytic modeling, and code development, that are facilitating and supporting commercial MHTGR development. The Department is developing a plan for the commercialization of a lead MHTCR plant.

No utility orders or commercial demonstrations of gascooled reactors are planned, but the design is one of two recommended for construction as a new weapons production reactor. (The other is a heavy-water reactor.) If the MHTGR is constructed for weapons mate. rial, it would be a step toward demonstrating the commercial potential of the design. Although successful operation of a MHTCGR for weapons production would advance the commercial prospects of the reactor, utilities and the NRC would impose additional demonstralion and lest requirements on the design of a commercial version. Public aceeptance of the design without a containment and cosit effectiveness of the design with a containment are important open issues. 


\section{Sodium-Cooled Reactors}

Sodium is the coolant of cholce in aclasis of reacors known as liquid metul redceress (LMRs). Thesse reactors, which lave substantially different characteristics and capabilities from the water and gas reactors, ate operating in most of the leading nuclear conntries. Advanced designs are on the drawing bourd in the United States and Europe.

The use of a liquid sodium coolant has certain advantages and disadvantages over water or helium. Favoring sodium is its extremely high heal-transfer sapacily and its extremely high boiling point. A large poul of sodium takes a long time to heat up, a long time (o) cool down, and recpures a great deal of heat to bovil. This means that the sodium eoolunt provides mach more lhermal stability llan water or gas. On the ollete hand, sodium is chemically reaclive, corrosive, and explosively lammable in the presence of oxygen. This means that sodium is much more difficult lo work with than either water or helium.

Sodium-conled reactors, however, have cerlain faverable characteristics for long-run sucecss. The primary characteristic is their capacity to breed fued (as in the term Liquid Melal fast Breeder Reactor). The use of sodium as a coolant permits efficient breceding of U.2.38 into P'11-239. Although the generation and reprocessing (s) eommercial plutonium is contentious and currently very meconomical, the long-run energy potential is very high. The second characteristic of some (but not all) melat-eoved reactor designs is the use of metal (versus oxide) fucls. Metal fueds, i.c., using uranium in its metallic form rather than its oxide form, offer a grealer potential for passive safety than any ofher reactor type (including water and gas, which cammot use: metal fuels). The possibility of on-site reprocessing, thus confining the plutorium, and reductions in the lype and radionctivily of waste products, thus simplifying the waste disposal problem, are other advantages of the proposed metal-fueled, sodium-conled reactors.

In the United States, the Department of Energy is continuing to fund development of the Power Reactor Innovative Safe Module(PRISM) concept led by General Electrici In 1989, DOE awarded GE a 3-year contract for 846.7 million for design work, including resolution of NRC licensing issues, and a 2 -year optional followon for $\$ 44.4$ million for preliminary design. DOE does not plan individual funding for a commereval demontstration. D) De has thus far not been successful in enlisting utility or foreign support for the nom-DO) funding required for a demomitration. With the sclection of the PRISM as DOE's reference 1.MR, work has ceatsed on the Sodium Advanced Fast Reactor (SAliR), an alternale I.MR designed by Rockwell International.
Once of the more promising approuches to resolving the issibe of long-lived waste poreducts is the lissioming of the actinde elements" in a licpuid metal renctor. L.MR fuel cun he designed fo aceept the actinicle waste products from l.MRs as well as 1.WRs. The neulron llux in a liquid metal rencelore can be designed on fission

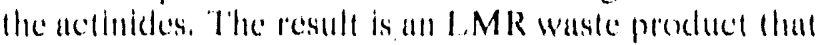
is largely fiec of actinides. Since the waste prodece has only lission prodace characteristics, he waste stream cain be processed for storuge over hundreds of yeurs rather than hundreds of thousands of years. Such an uppronch fo fucl sycle manngement simplifies highlevel waste storage, It also reclaims the fice value of the uranimm and plutionium discarded in the origimal L.WR finel cycle, provides part of the leed for the L MR finel eycle, cileales a common 1.WR-I.MR finel cyclewaste stream process, and has the polential lo reduce plutonium proliferation problems.

The leading advecale, ol antinde control in the United Stales (and the world) are the developers of the Integral Gast Reactor (JPR) al Argonnc Nalional laboralory. The IfiR fuel cycle is being designed with an inlegral electrochemical reprocessing technique that isolales actinide wastes, matolains the isolated wastes in an intensely radienctive form (to make off-site diversion of nuclear material impossible), and reforms the waste and fresh feed inte a metal fuel (rather than an oxide fucl) for insertion into a liquid metal reactor. "This design is gaining increasing attention around the world, both as a mealls of addressing waste problems and as a potential competitor in the narket for reactors designed wilh passively sale fealures.

\section{Nuclear Power Plant Decommissioning: Cost Estimates and Estimating Methodologies}

\section{Introduction}

One issue of increasing importance to the future of nuclear power worldwide is plant decommissioning. Recent experience has reduced the lechnical ancertain ties associated with this activily: however, there is still a substantial amount of uncertainty ahout the costs and coonomics of dismantlieg a $4($ )-year-old, large-scale, eommercial reacters, These uncertantices eould alferet the economics, as well as aceeptance by the public and the financial matkels, of fulure nuclear power plants. This section, therefore, discusses some issues associated with nuclear power plant decommissioning costs, concentrating on the issues that drive the economics of decommissionimg.

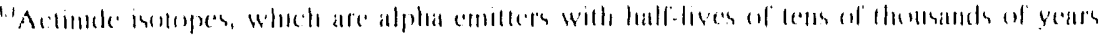




\section{Cost Estimators}

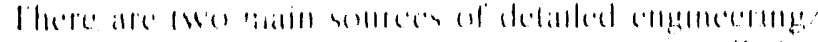

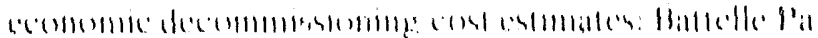

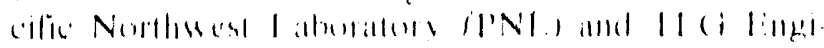

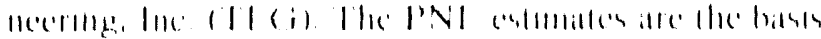

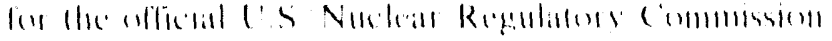

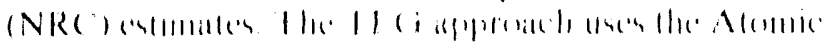

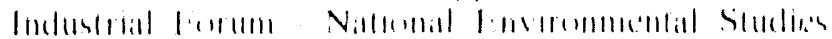

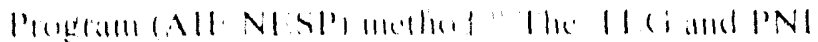

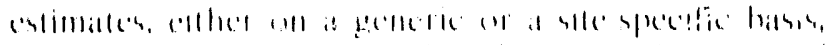

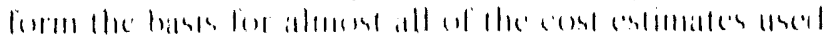

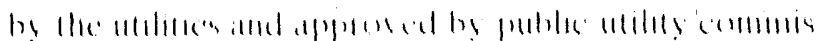

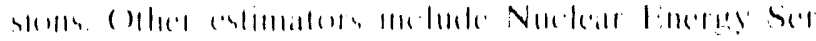

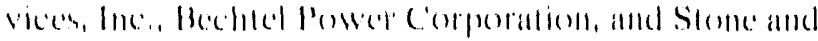

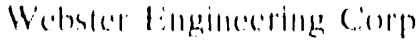

\section{Background on Principal Cost Estimates}

1 he l'Nl chtimales atre based ont stodies origimally

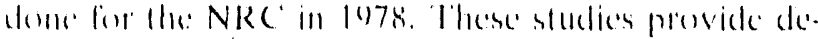

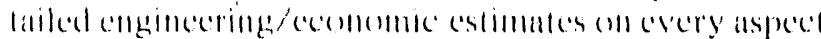

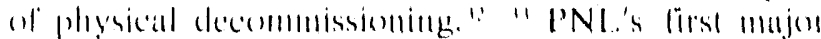

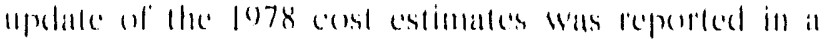

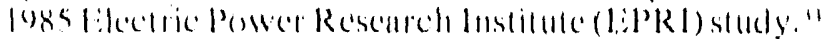

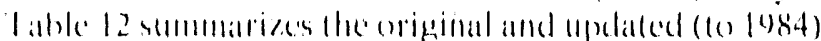

\section{Table 12. Summary of Reevaluated Decommissioning Costs for Light-Water Reactors}

Estimatod Costs (Million 1984 Dollars)

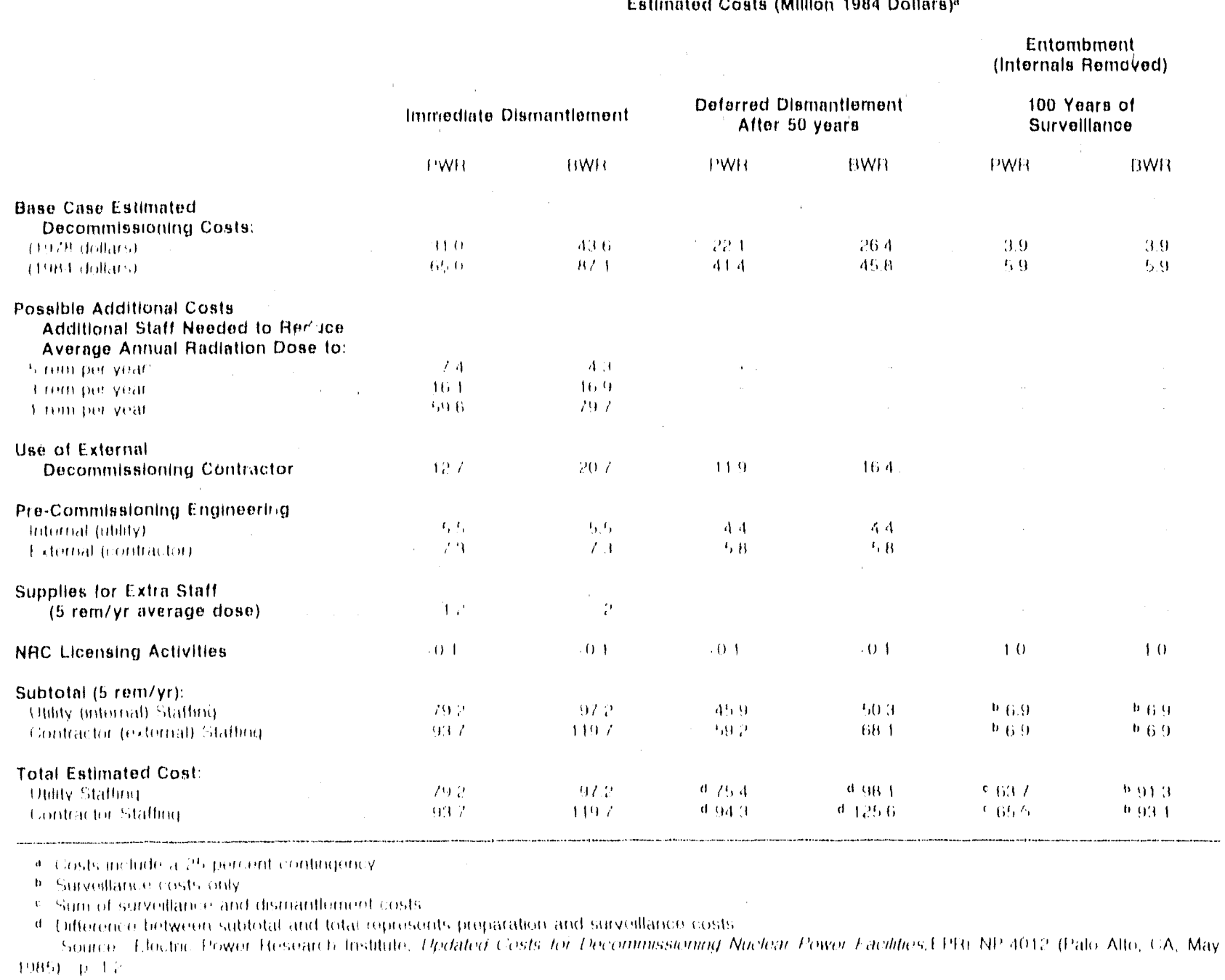

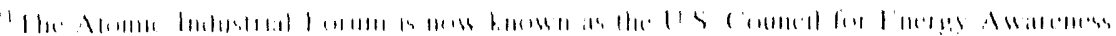

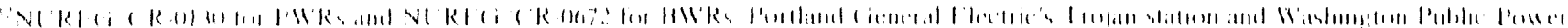

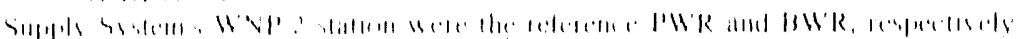

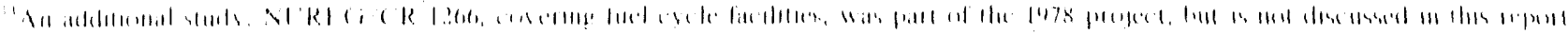

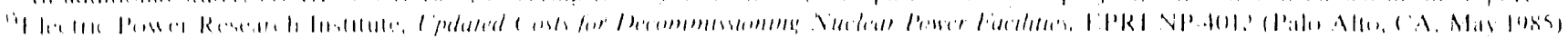




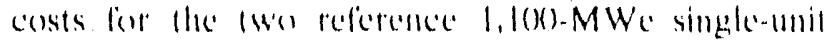
power plants. The total cost for immodiale dismamble.

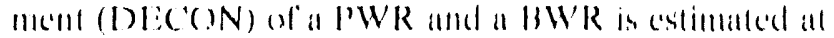

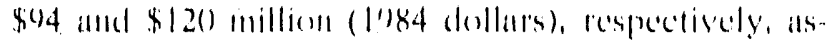

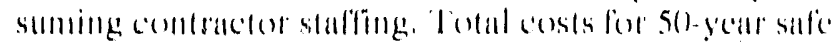

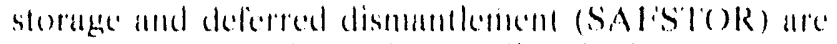
estimated lo be a fow million dollars highere.

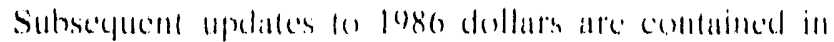

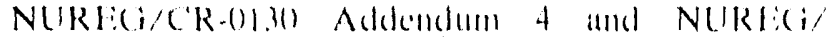

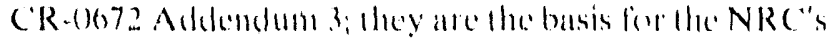

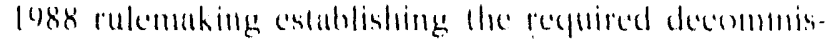

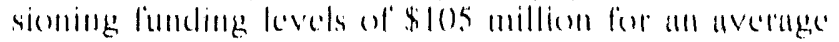
1.1(x)-MWe l'WWR ansel \$1.35 million fin an average 1. I(x)-MWe BWR. I ower fundinge levels are speciliced

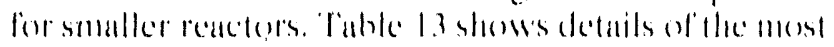

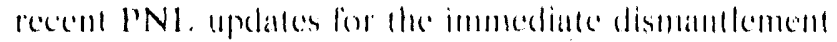
(I)LCON) case for the reloreme l'WR and BWW The

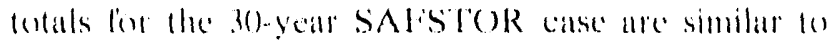
the onces for bece (o) and lor purposes of hrevity are nol shown.

leture cost estimates (mol NRC fundme reyuirements) can be estimated over lime by adjustimg the base case: physical decommissioning requirements for changes in

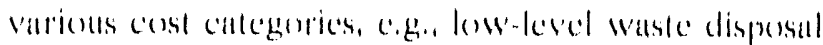

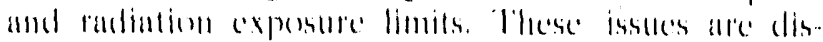
cussed lilley.

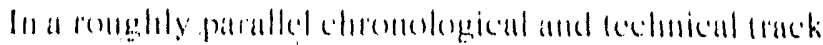

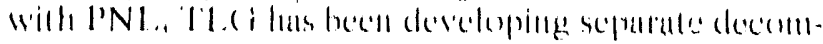

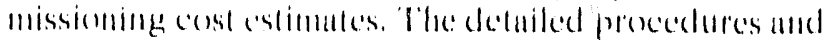

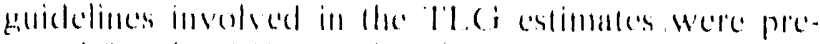
pared for the All-Nlisl'. The most recent estimates

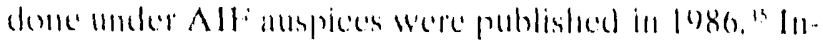

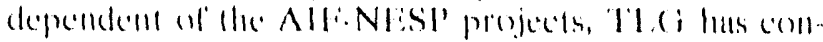

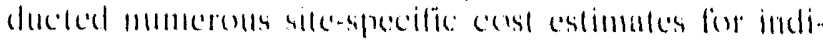

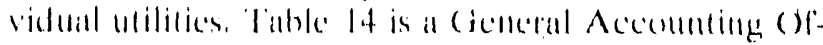

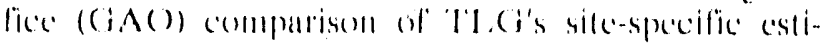
malces lo NRe"s estimales. "The The e cimblimles are

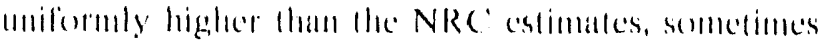

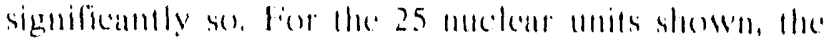
NRC estimalles averaged 20 pereent lower, or $\$ 4.5$ mil-

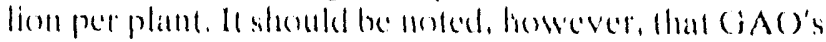

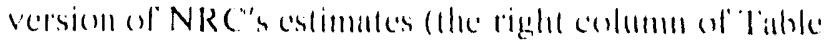
14) is the resulf of simple sculing aceording fo size, of the reference BW'R and PWR analyses mollow than any detailed plantespecific analysis, $(i \Delta)$ also lowered the T1. Ci estimales fo exclude demolition and sile restoration, since the NRC does not include these ceosts in its decommissionimg estimates.

\section{Table 13. Summary of the Estimated Cost For Immediate Dismantlement of a Reference PWR and Reference BWR (Millions of 1986 Dollars)}

\begin{tabular}{|c|c|c|}
\hline Cost Category & PWR & BWA \\
\hline \multicolumn{3}{|l|}{ 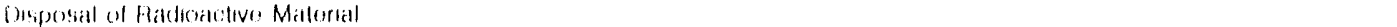 } \\
\hline 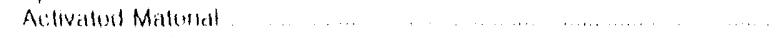 & if 4 & $7 i$ \\
\hline bonlammbited lntemalls, ....... & 40 & :3! \\
\hline 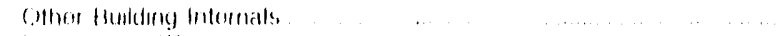 & 190 & \\
\hline Radtoalcilive Watsde... & 21 & a $\therefore$ \\
\hline 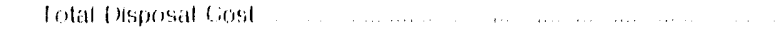 & : $11 !$ & 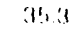 \\
\hline$\ldots \ldots \ldots . . . . .$. & 144 & $2 \beta 3.1$ \\
\hline Intrity & (i) $/$ & 11 \\
\hline Spercial Trsuls and l qupment & 1.1 & $3 ?$ \\
\hline Miscollantreous Supplenti & $\because !$ & 30 \\
\hline Sipecelally somitractors & ii & i; \\
\hline Nui luál Int:unalliat. & 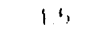 & $1 !$ \\
\hline Invirermentilal survesllances & :1 & \\
\hline$\ldots \ldots \ldots \ldots \ldots \ldots$ & 1 & 1 \\
\hline Cosil Aiders. & 60 & 31 \\
\hline 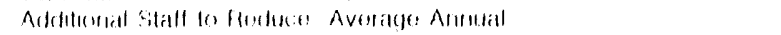 & & \\
\hline 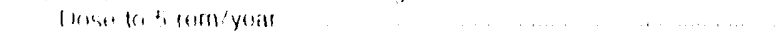 & 1013 & $16 i .1$ \\
\hline 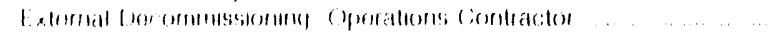 & 1,9 & 5.4 \\
\hline 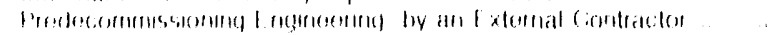 & 10 & 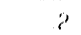 \\
\hline 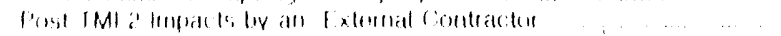 & $i$ & 1 \\
\hline Sultutal & si' 8 & 106,1 \\
\hline at, persond contmyenc; & 201 & ifiall \\
\hline lotint & $10: 14$ & 1318 \\
\hline
\end{tabular}

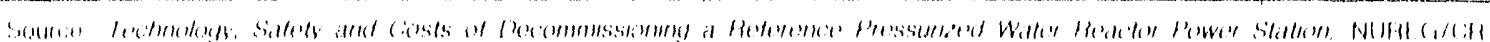

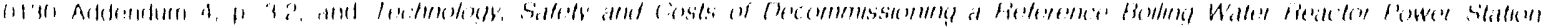

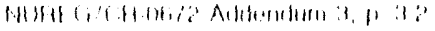

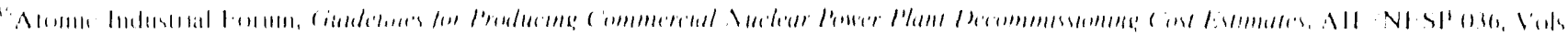

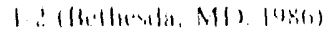

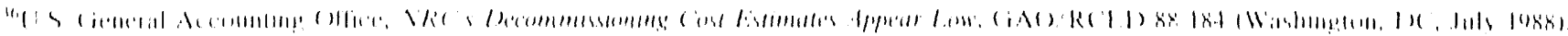




\section{Table 14. Comparison of TLG Site-Specific Estimates to NRCs Cost Estimates}

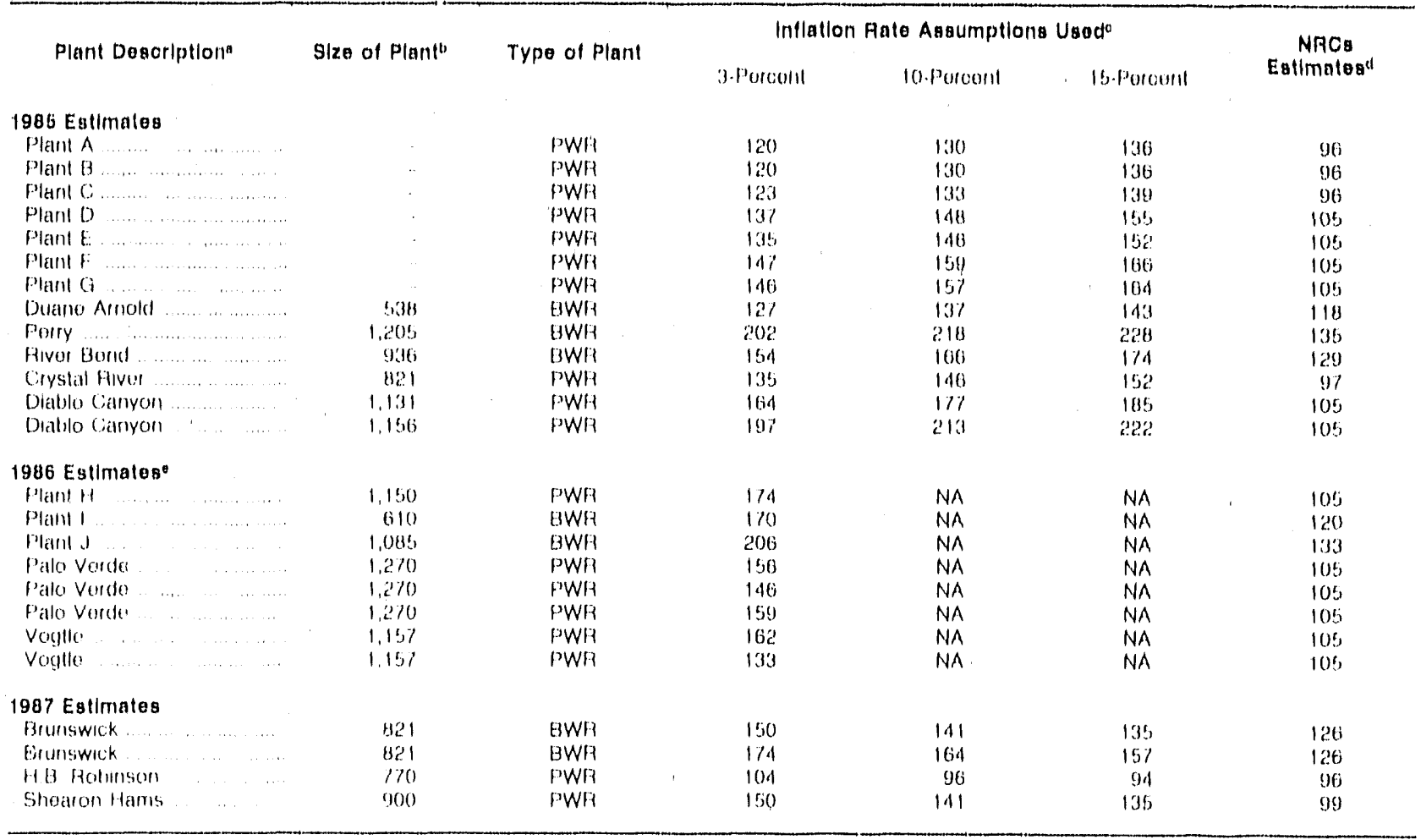

a Sorne pant names could not be used becauso indormation is considered proprotany

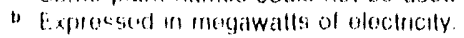

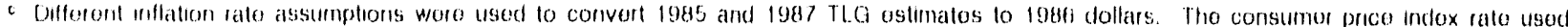

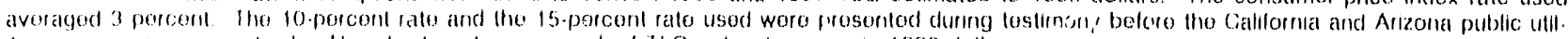

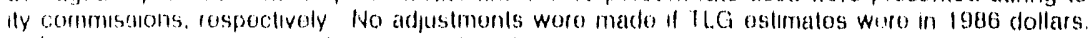

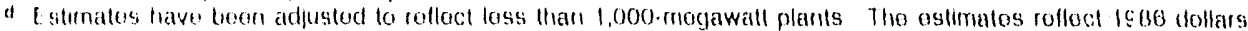

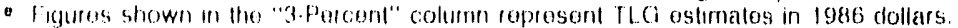

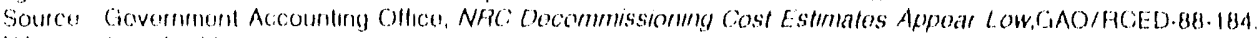

NA not applicable

\section{Basis for Cost Estimating}

The l'NL and The $i$ costerstimating technicpues are similar. In each catse, the physical atspects of decommissioning, including planning, stafting, operations, and waste disposial, are divided into work units. Measurements of lime, worker radiation exposure, equipment requirements, and component removal are made for each lask. Difliculty factors are applied to cach task. The talsk estimater are then summed fo yicld a "botlomup" enginecring cstimate.

PNL, and The a agree on what technical activities are necessary to complete ench type of decommissioning. Both cost cestimates include anginecring, planning, conttractors, !aborr, waste transportation, waste disposal, power consumption, and oflerer processen necessary to relurn the site to a releasible. monradionetive state.

Important atsumptions implicit in the cost estimales are:

- No cexpectillion or andjustment for botflenecess in laberer or mallerials
- Sufficient lead time le manufacture all required cepuipment and obtain all required labor and malerials

- All special eceupment casily produced

- Labor supplied by existing building trade unions

- No problems mecting the Al.ARA (As low As Reasomably Achicvable) radiation exposure limits.

Some important costs ussocialed with the physical aclivity of releasing a nuclear sife for unrestricted use are not part of the decommissioning cost estimates. 'The removal, packaging, shipping, and disposal of' spent fuel, including pool-stored fuel, fuel in casks, and the final core, are not decommissioning costs but plant operating costs. The ultimate disposal of the spent fuel poses a potential problem for some mits, however, hecallse the long-term high-level wiste disposal repository is courently projected to be available to aceept waste in 2010, and 12 of the 110 operable mits (yenr end loge) are scheduled lo be retired before then. Unless a temporary site, such us the monitured relrievable: storage, becomes available, uilities have the following 
oplions if the plant is redifed befiole 2010 :

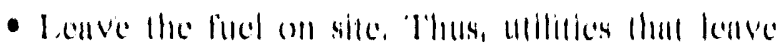

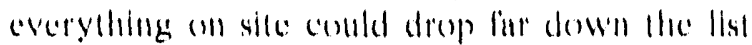
for repository shippling.

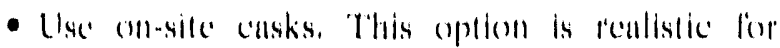

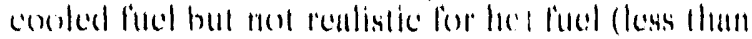
aboull 5 years oull of core), Shipment of consks lo

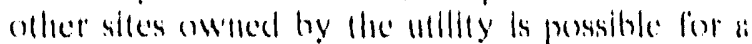

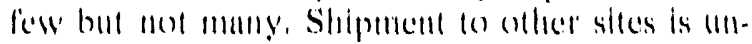
likicly.

- Ship the spent finel lo frunce lor reprocessing. I1 is nol clear if this is legal, bul some U.S. millities have presposicd il.

- I.ife-extend the unit.

- Ship the fied to a monitored redrievable storige (MRS) facility, if one: is available.

The most likely ontcome is llat fucl will be lell on-sile

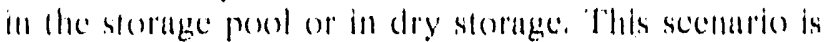
called "oold shutdown." Levery utility is aware of this pessibility, hut monc is accounting for it or preparing alficial estimates of its cost. 'TLC has developed an umpublished estimate that a 4-year delay in beginning decommissimong at one small BWR would cost $\$ 28$ million (les8 (bollars) for minimum utility stall labor

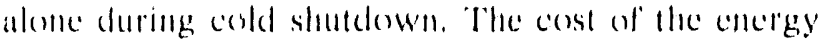
neceled for decommission the unit was estimaled at $\$ 1$ million lo $\$ 1.5$ million per yeir. No comlingencies, ()\&M, repaits, decommissioning comtractor (D)C ) ar cxitra securily was included.

Neither the demolition and removal of momradionctive structures mor the restoration of the site to a greentield condition is part of the decommissioning cost estimates, since there is no NRC requirement for these tastis.

An important additionat ancen of agreement in cost esitimaling is on the use (if corrent actual costs rather than projected costh, even though the decommissioning activity itsedf is mot scheduled fint many years, and the finture costs are erertain to he higher han current costs. Thus, the eost of low-level wille disposal, a key cost component, is based on current waste disposal charges, not the moch higher projeceled chatrges ander the forthcoming regional compacts."

\section{Sources of D/sagreement over Cost Estimates}

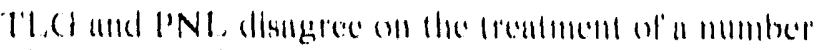

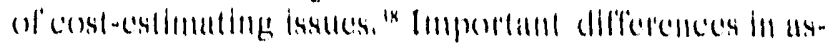

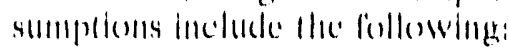

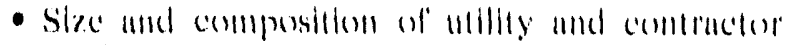
silullis

- Simgle versils double shliling

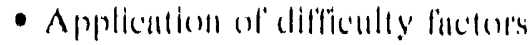

- P’ipcocoutling assumprtions

- Stcinar gencriator removal

- 1) collicililion.

Size and Composition of Litilty and Contractor Stuffs

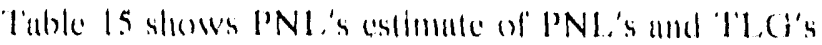

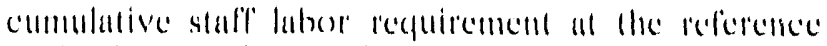

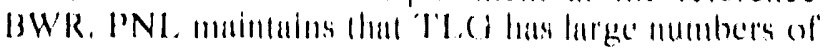
extra stalf' in several areas, focluding conginecels and ecolmicians and additional staff time for secority per-

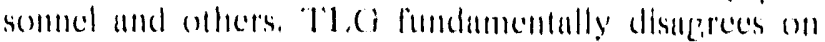

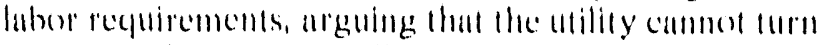
over complete responsihility o the locemmissioning

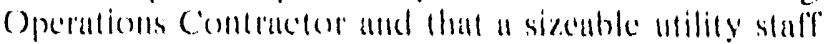

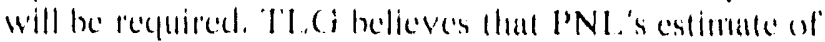

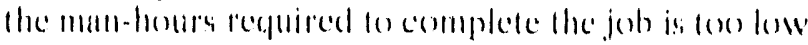

\section{Single Versus Donble shifting}

PNI. estimales are based on lwo shilts per day. TI. estimales ance based an a single shift. Disagreement on this issulle is declining as l'NI. includes certain cost linc.

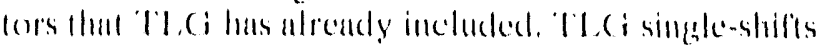
everything except collting and packinging the reactor

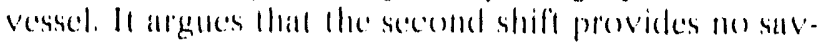
ings since aldelitional costs are created by extra management staft, the secomel-shift wage dillerential, a s()-pereent preminum ont eyuipment rental, and reduced

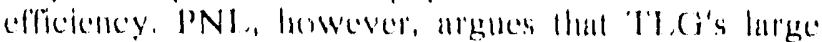

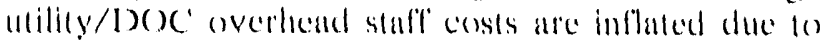
the length of the decommissioming period under a single-shift approach.

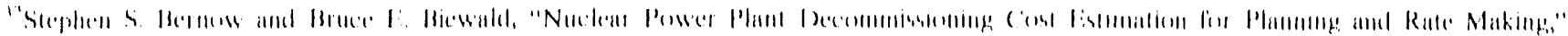

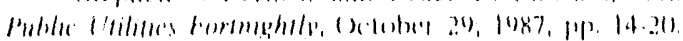

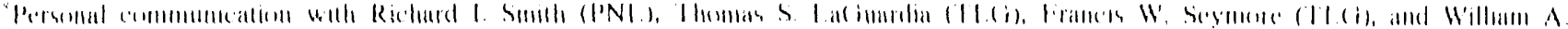

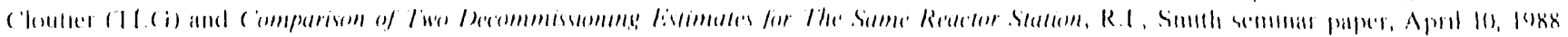




\section{Table 15. PNL Comparison of Staff Labor Estimates Without Demolition at Reference BWR}

(Stall-Yoars)

\begin{tabular}{|c|c|c|}
\hline Ontogory & TLa & PNL \\
\hline Utilily & d!n & $11:$ \\
\hline$\ldots \ldots \ldots \ldots \ldots \ldots \ldots \ldots \ldots \ldots$ & :16,: & $18{ }^{\prime}$ \\
\hline Wox: Worken! & 50 & (1110 \\
\hline loltal $\ldots \ldots \ldots \ldots \ldots \ldots$ & 1.411 & $i n$ \\
\hline 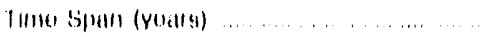 & 1 & 4 \\
\hline
\end{tabular}

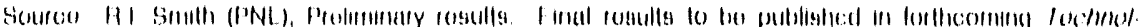

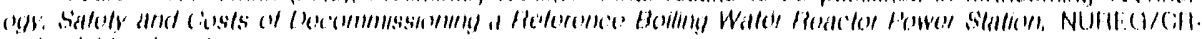
(it) 7 : Addondumin a

\section{I)ifficulty linctors}

Difficully lictors are used lo acljust busice lime esti-

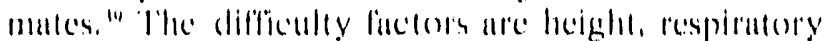

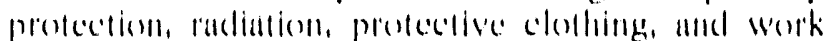

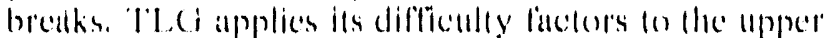

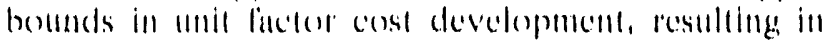
higher estimales of the cosst of a joh than l'NI.

All example used by PNI, is Tleci's upplicillon of dif-

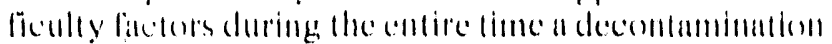
rig is in operation and the werkers are largely wationg for the decomburmination solution to complete its ciren-

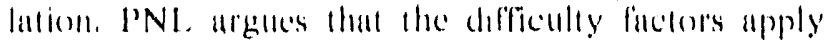

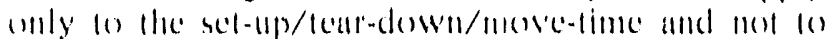

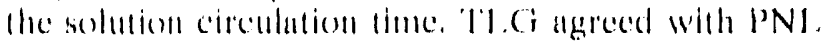

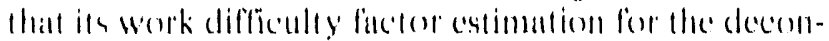
lamination rige example may be high. However, Tl.ci

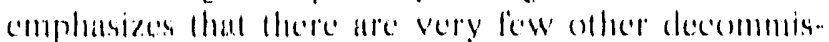
sonimg operations where the stal't sets up some seguipment (subjecel to work diflicully factors) andel lhen waits while the ecquipment works by itself.

\section{Pipc-C'utting Assumptiorss}

The piperestling disangrecoment is over the average kenglh of a cul pipe and the average difficentey finctor, PNI. estimates that a cut is mecessiary, on averager, c.v.

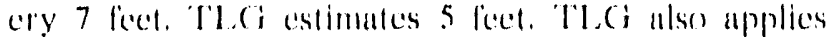
higher difficully factors to the lask. According of PNI, He combined eflect of fe'wer culs and less difficulley is a significant coss reductions. Th, (a argues that 5 fece s appropriate but disputes the motion that it is possible to specily dle average pipe coll preciscly withoul inspecting every pipe. In lle pipe-coulting area and

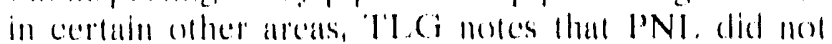
restatle its 1078 receuirements in the light of post-7'MI backlits, onleer hacklits, incrensed complexity, and

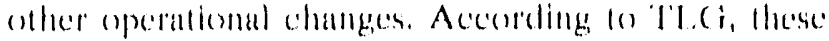
changes, by addinge lots of hending pipe, mdding new' structures that interfere will pipe and ollher stroctures,

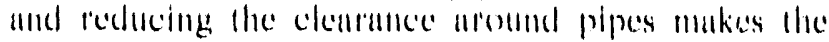

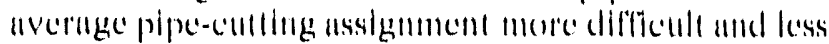

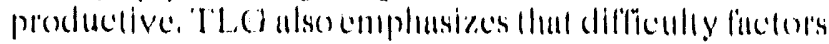
are an average of the available werking space la goed and bud planls.

I'NL, states that its review of backlitted plants showes minimal imponet on decommissloning costs. PNL, estlmates the cosst impace on BWRs and PWRs from poste TMI bucklits to be ubout $\$ 1(0),(0)(x)$ and $\$ 2(0),(x)(0)$, I'spectively. I'NL also disagrees whllh whan it describes

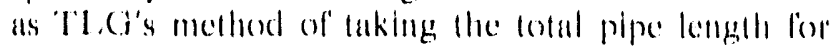
the plant and dividing by five fo arrive al the average: number of pipe cuts.

\section{Steum Ginerutor Removal}

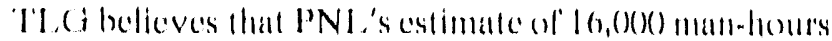
(1) remove four steam generators is low. Tle (i noles

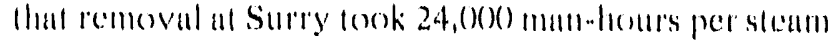
gencralor. (The Surry removal look place after PNI. made lls 1978 estimales.) PNI provides an extensive summonty of steum generitor removal issues (mostly from the perspective of ocecuputional desese in tis NUREG update. Although PNI. acknowledges un-

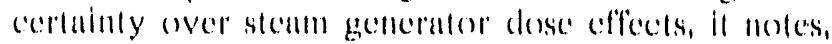
that recent experience al Siveden's Ringhals PWR sup)portsi its belief' then the operation can be done mush more culckly and simpiy thun Tlea bolicves.

\section{Summary of Cost Differences}

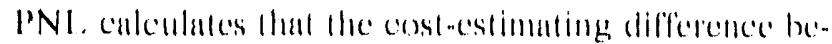

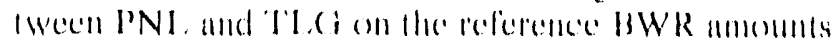

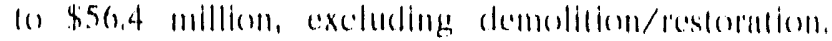
This figure is cullowlated us follows:

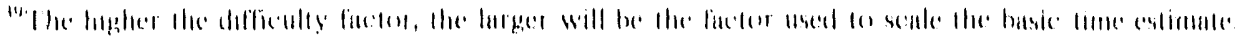


C'interyory

('ust

(Milli(n)is)

Size al Ulilly/g(x). Silull

$\$ 24.5$

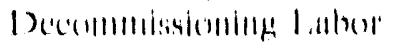

$\$ 11.1$

() (1he'

$\$ 15,8$

livil|

$\$ 5(1,4$

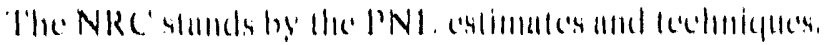

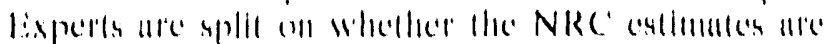

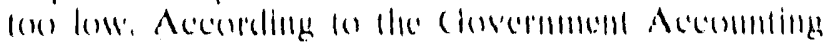

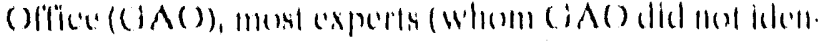

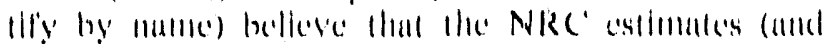

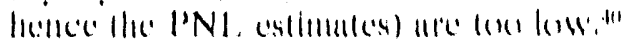

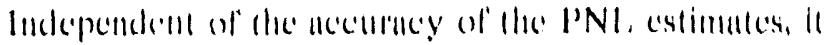
is NRC"s posilionl that the funding levels in lis

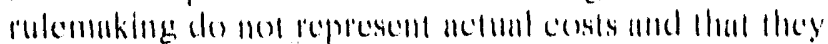

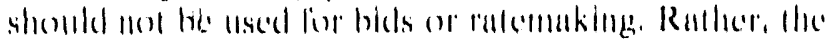

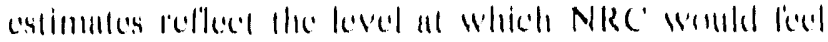

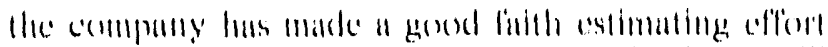

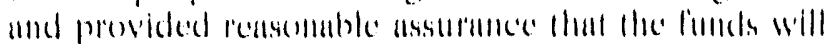

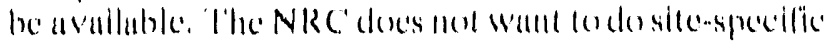

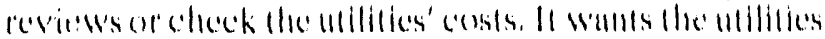

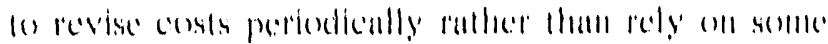

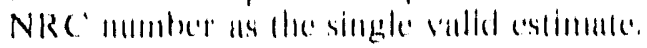

\section{Sources of Cost Escalation}

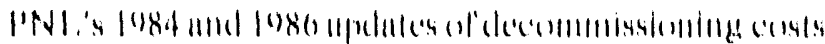

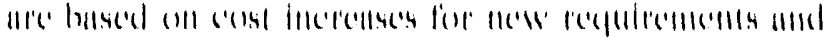

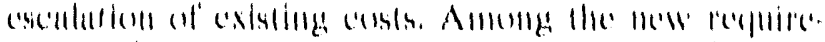

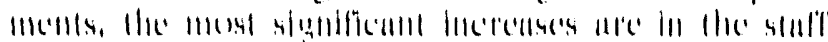

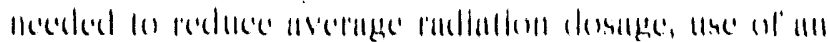

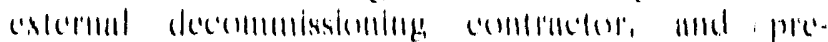

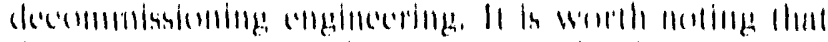

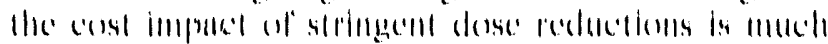

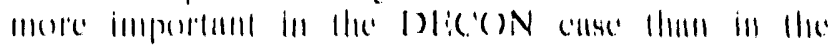

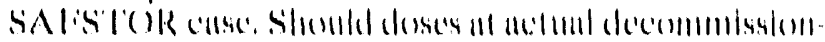

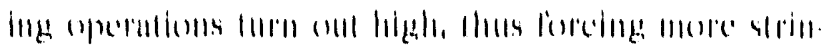

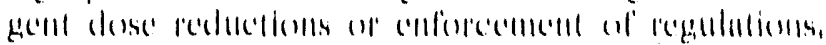

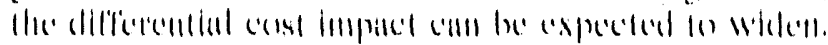

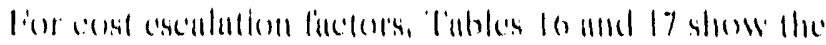

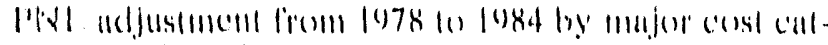

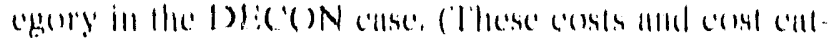

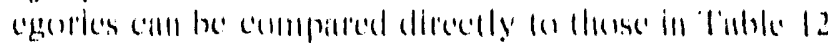

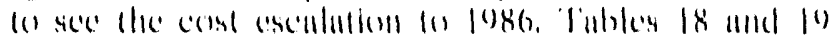

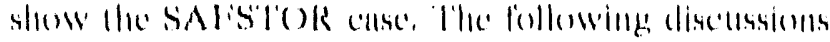

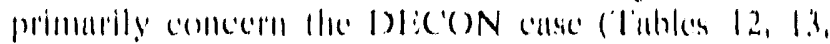

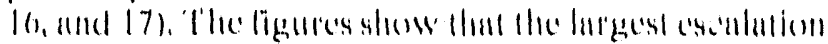

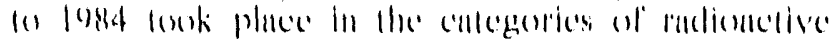

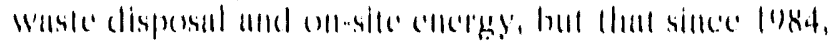

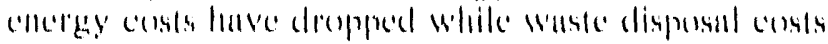
linver soureds.

\section{Table 16. PWR: Adjustment of Estimated Costs for Immediate Dismantlement to 1984 Cost Base}

\begin{tabular}{|c|c|c|c|c|}
\hline Cont Catoyory & $\begin{array}{c}\text { Estlimatad } \\
\text { 107t Costa } \\
\text { (milliton dallnra) }\end{array}$ & $\begin{array}{l}\text { Cost } \\
\text { Aclpatmont } \\
\text { Fnotor }\end{array}$ & 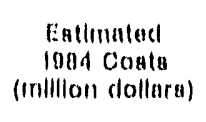 & 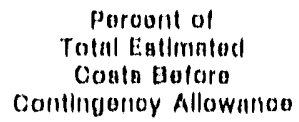 \\
\hline \multicolumn{5}{|l|}{ 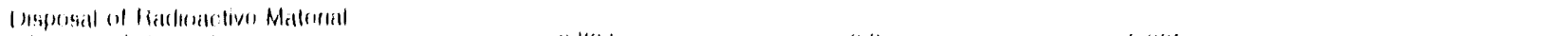 } \\
\hline Nemlent Aclivatend ... & $\because \because: 3$ & $\because \because$ & $1,4 ! 1$, & \\
\hline (ionlinimualent & !1. 181:1 & 10 & $1\}: 1 ! 10$ & \\
\hline Hathenativar Wastus & Git:1 & $\therefore 1$ & $1111: 1$ & \\
\hline 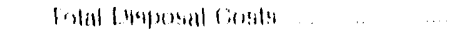 & $11(i 11)$ & $\because 1$ & in? & $4:$ \\
\hline Stall tulku $\ldots \ldots \ldots \ldots \ldots$ & (1) & 16 & $14: 170$ & $\because 6$ \\
\hline Innogy $\quad \ldots$ & $: 1,5(x)$ & $\therefore \mathrm{i}$ & !) 1110 & $1 / 1$ \\
\hline 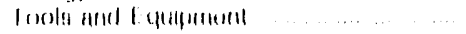 & Ur':! & $1 !$ & $1: 1: 1$ & $\because 1$ \\
\hline Miscollanerous silppller, ... . . . . . & $1+5 ! ! !$ & $1 !$ & $\because 3: 11$ & $4 !$ \\
\hline 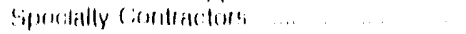 & t.14 & 16 & 1170 & 17 \\
\hline 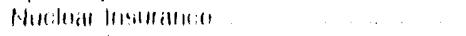 & $(11)(1$ & 14 & $11: 0$ & $\because 1$ \\
\hline I Nonmat f & 0 & & 11 & 11 \\
\hline Sintitulial & id $\mathrm{B}: \mathrm{O}$ & & 9.6014 & 10011 \\
\hline Comlumbunky & $(i, i) h$ & & 1.10111 & \\
\hline 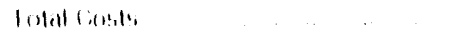 & 3116 & $\because 1$ & $(1,0)(1)$, & \\
\hline
\end{tabular}

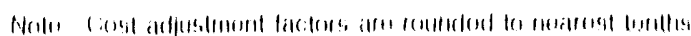

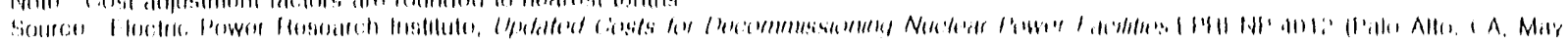
$1(14,1), 11: 1:$ 


\section{Table 17. BWR: Adjustinent of Estimated Costs for Imınediate Dismantlement to 1984 Cost Base}

\begin{tabular}{|c|c|c|c|c|c|}
\hline Cont Calogary & & $\begin{array}{l}\text { Estimatod } \\
\text { 1078 Cuata } \\
\text { (Inllilon dollara) }\end{array}$ & $\begin{array}{l}\text { Oost } \\
\text { Aclinalineill } \\
\text { inotor }\end{array}$ & 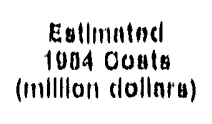 & $\begin{array}{l}\text { Poronnt of } \\
\text { Totnl Eatlmatod } \\
\text { Ounta Holoro } \\
\text { Oontlingonoy Allownion }\end{array}$ \\
\hline \multicolumn{6}{|l|}{ 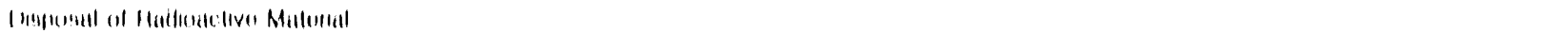 } \\
\hline Nenitrent Ar livillad & & $2: 10(1)$ & : & 小, & \\
\hline 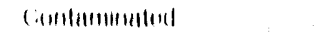 & : & $1(10)$ & $1, i^{\prime}$ & 16.000 & \\
\hline Hateliculd live Wastens & $\therefore$ & $1.1011)$ & $\therefore(1)$ & $\because 1670$ & \\
\hline 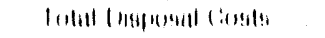 & & $\| 11 / H$ & $\because 4$ & $2: 4317$ & $d a$ \\
\hline slall I ،114.1 & & $1 / ., 0111$ & 1.11 & 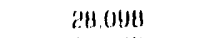 & $\because 10$ \\
\hline I llenlly & & $: 1914$ & $n$ & $\{(1,6)+\}$ & $17 !$ \\
\hline 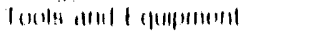 & & $\therefore(0) 10$ & $1 !$ & a.0.4 & 2.4 \\
\hline 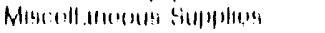 & & $1.11 ! ! !$ & $1 ;$ & $\therefore / 16 !)$ & 14 \\
\hline 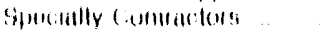 & & $\therefore 116$ & 10 & $11 / 0$ & 1.7 \\
\hline 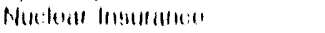 & . & $111)$ & 1.1 & 1.100 & $\therefore 1$ \\
\hline I. 16:01160) I $0(1+4$ & & $0 ! i$ & $n$ & 1) & 11 \\
\hline tilllulolill & $\therefore . .$. & (II) 1610 & & $(16) 0(3)$ & 100.0 \\
\hline Combrogentisy & i........ & $11 / 110$ & & $1 / .111$ & \\
\hline lolal (andsea & & $1: 1,190$ & $\therefore 0$ & $11 \% .01313$ & \\
\hline
\end{tabular}

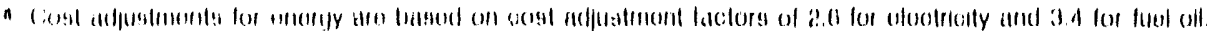

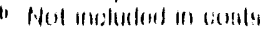

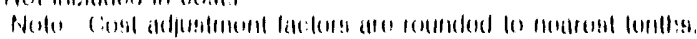

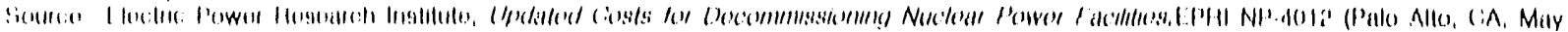
$1 ! 14 ! 1), 11 ;$

Table 18. PWR: Adjustment of Estiniated Costs for Preparations for Safe Storage to 1984 Cost Base

\begin{tabular}{|c|c|c|c|c|}
\hline Conl Calogory & $\begin{array}{l}\text { Estlmatod } \\
\text { lo70 Costa } \\
\text { (milllon tlallara) }\end{array}$ & $\begin{array}{c}\text { Coss } \\
\text { Aclluatmont } \\
\text { Pautor }\end{array}$ & $\begin{array}{c}\text { Eatlimatod } \\
\text { lath Costy } \\
\text { (milllan dollars) }\end{array}$ & $\begin{array}{c}\text { Poroent of } \\
\text { Tolal Estlmatod } \\
\text { Costa Botora } \\
\text { Cominganay Allowanoo }\end{array}$ \\
\hline \multicolumn{5}{|c|}{ 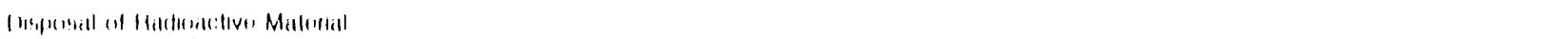 } \\
\hline 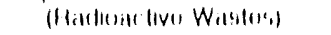 & 0 (ind) & $\because 1$ & $1.34 \%$ & 18.7 \\
\hline Silill l allus & $10 ! 1$ & 10 & G.tHa & 10.9 \\
\hline 1 mutely & $1.116 t$ & $i(i$ & $4.14 ! 1 !$ & 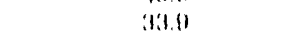 \\
\hline 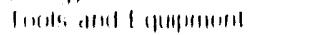 & $01 !$ & 16 & $11: 1$ & 11 \\
\hline 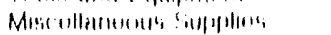 & $m H_{i}^{\prime}$ & 1.6 & $101+4$ & $(1.4$ \\
\hline 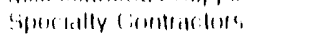 & $10 !$ & $10 i$ & $A B A$ & 1.4 \\
\hline 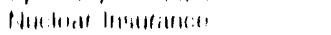 & ili & 1.1 & $110^{2}$ & $\because 4$ \\
\hline $\mid 11.111+1,16116$. & 11 & & & \\
\hline ' M11:t,1) & i tiati & & |4:I01 & 10000 \\
\hline 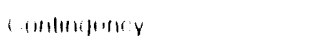 & $1 ! 101 i$ & & $: i 1, / 6 i$ & \\
\hline 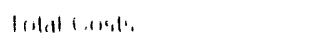 & $01,1,14$ & 111 & 1) (1) & \\
\hline
\end{tabular}

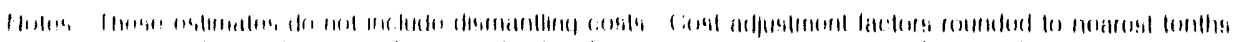

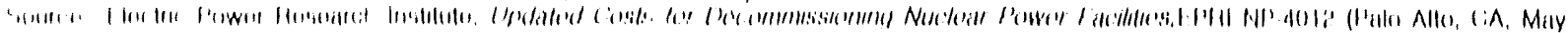
$10 n+111$ 


\section{Table 19. BWR: Adjustment of Estimated Costs wy Preparations for Safo Storage to 1984 Cost Base}

\begin{tabular}{|c|c|c|c|c|}
\hline Oost Ontasjary & $\begin{array}{l}\text { Laflinalod } \\
\text { 10\%0 Oagta } \\
\text { (millilon clollira) }\end{array}$ & $\begin{array}{l}\text { Cost } \\
\text { Acl|custrinint } \\
\text { inotar }\end{array}$ & $\begin{array}{l}\text { Pallimalod } \\
\text { logd Oonta } \\
\text { (milllon dollara) }\end{array}$ & 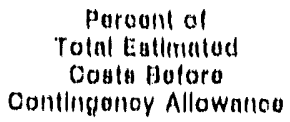 \\
\hline Stull t.utou & $11: 34.4$ & 10 & 16.006 & $\|$ bill \\
\hline In⿴囗十) $\ldots \ldots \ldots$ & i! lian & $"$ & 11.817 & (1) \\
\hline fools and | (1) & (ab) & 16 & 407 & 11 \\
\hline 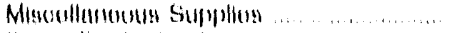 & $1: 101$ & $1, \because$ & $\because(14: !$ & 611 \\
\hline 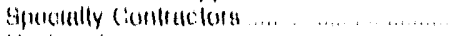 & 160 & 10 & :114 & 1.0 \\
\hline 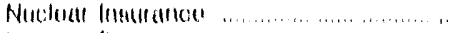 & $b(0)$ & 1.4 & 100 & $\because \therefore$ \\
\hline 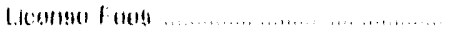 & $0 ; 11$ & 10 & (1)ill & 1 \\
\hline 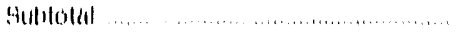 & 17.0148 & & $311.31 ?$ & 1000 \\
\hline 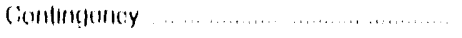 & 4.680 & & $1,1,11$ & \\
\hline 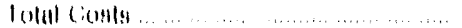 & 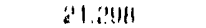 & 1.4 & $3 / 00)(i$ & \\
\hline
\end{tabular}

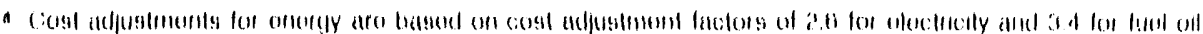

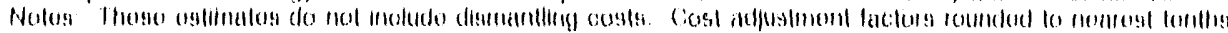

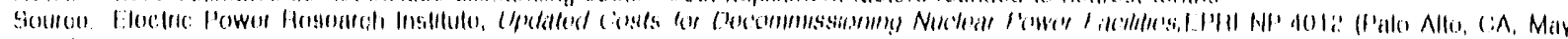
$1 !(15), 111 \%$

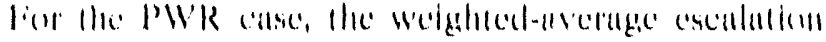

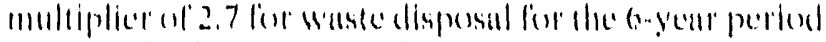

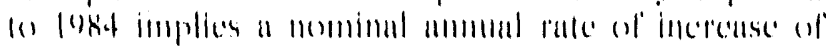

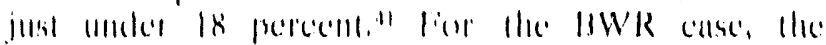

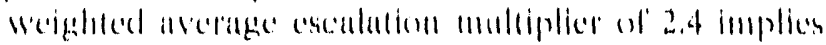

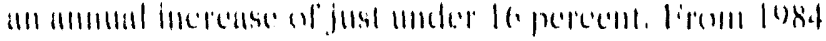

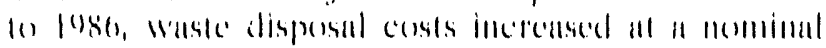

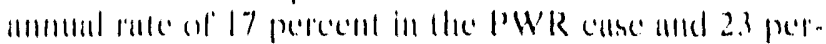

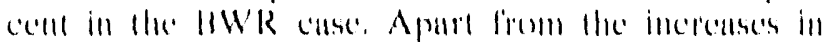

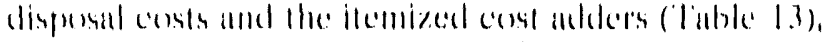

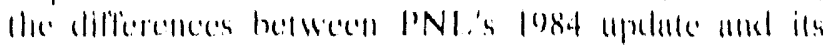

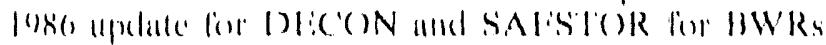
and lew'Rs arre mincor.

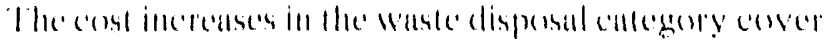

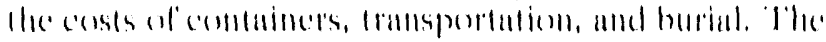

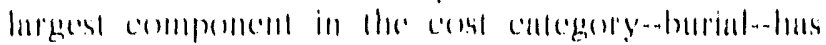

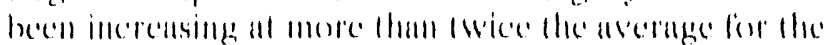
callegury.

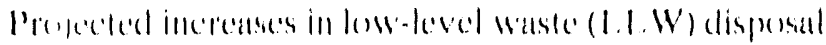
(2)

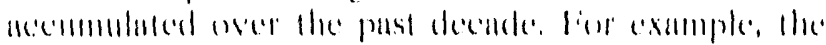

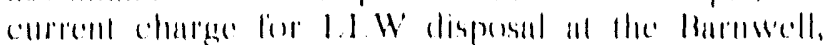

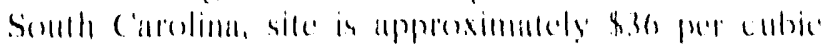

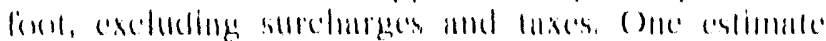

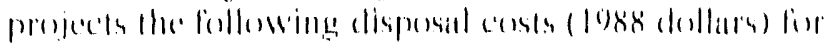

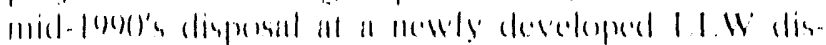
purial sille."

\begin{tabular}{|c|c|}
\hline Disposal Volumen $\left(\mathrm{ft}^{3}\right.$, & $\$ / R t^{3}$ \\
\hline $50,(10)$ & 2411 \\
\hline $1(x),(x)$ & 140 \\
\hline 1.50$),(1)(x)$ & $l(x)$ \\
\hline $2(x),(x)(x)$ & $(9)$ \\
\hline $5(x),(x)$ & $(0)$ \\
\hline
\end{tabular}

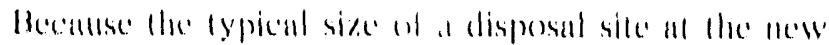

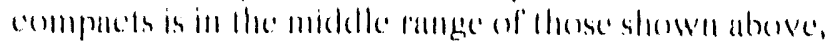

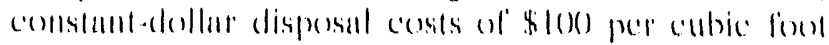

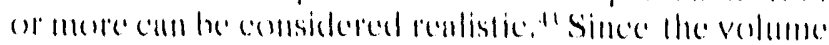

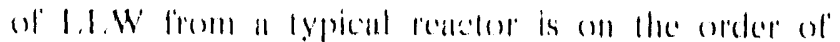

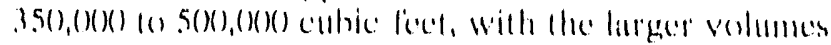

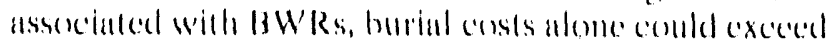

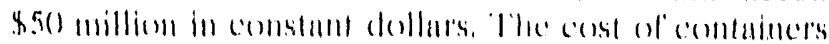

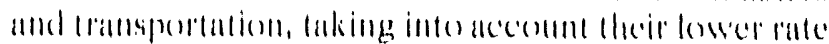

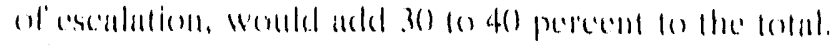

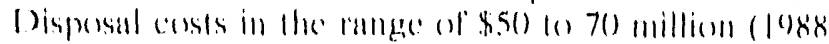

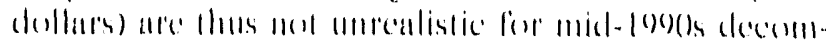
missioning. These ligutes compure with comronl PNI.

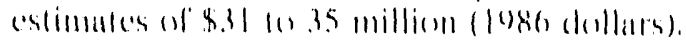

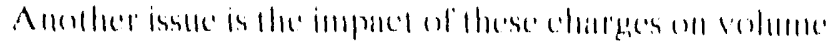

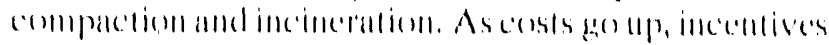

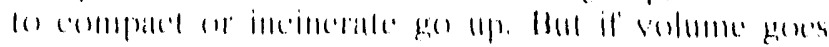

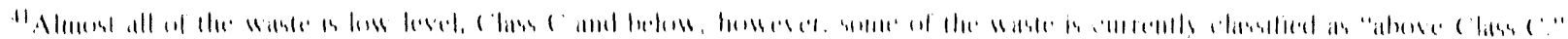

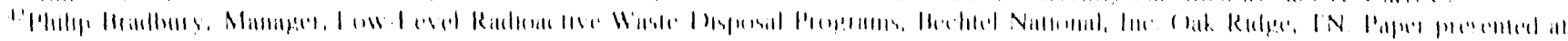

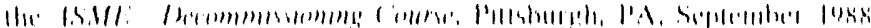

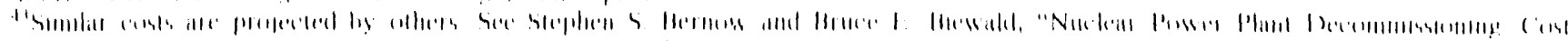

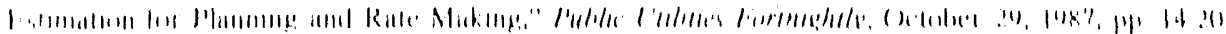




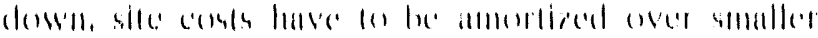

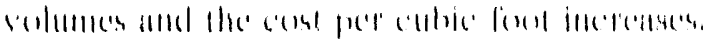

\section{Actual Versus projected ('usts}

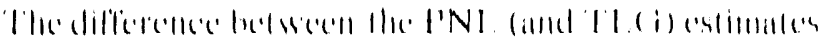

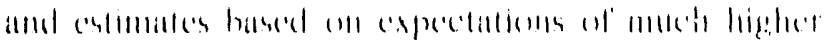

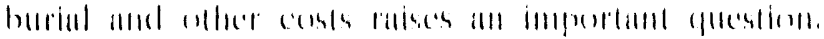

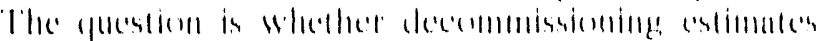

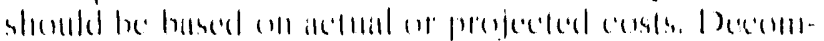

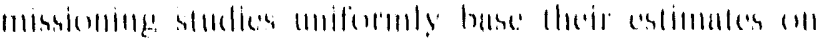

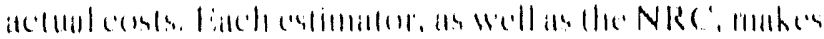

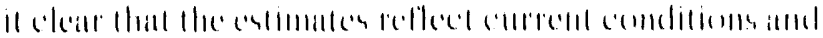

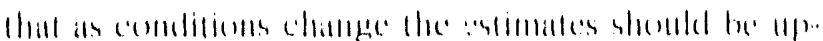

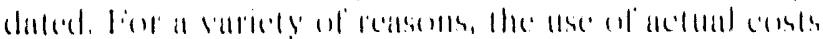

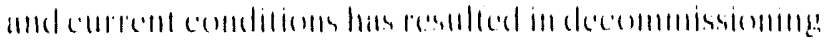

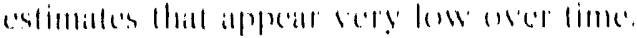

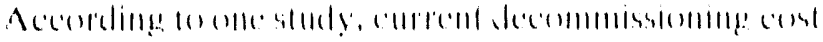

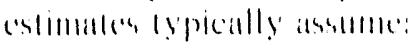

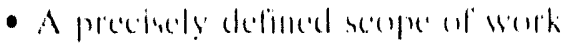

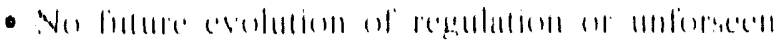
lechomengeicial problems

- No real pricereracalallion

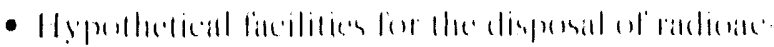
livi: Malsh"

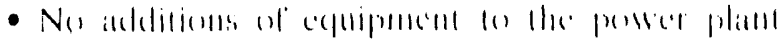

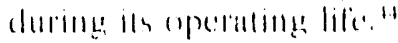

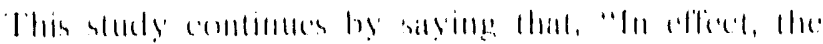

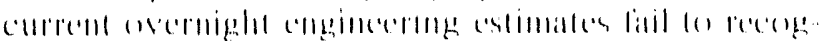

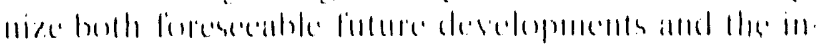

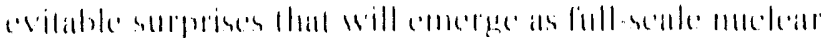

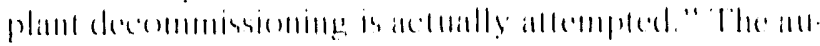

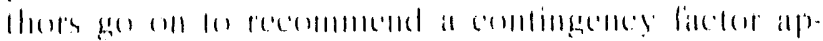

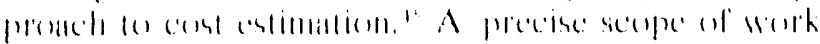

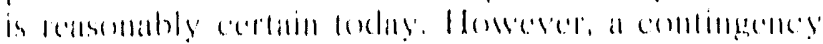

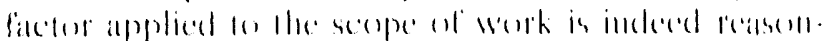

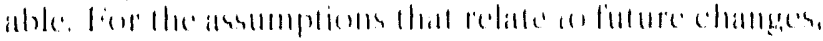

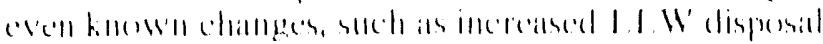

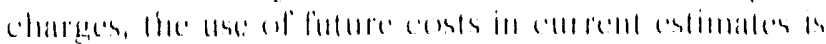

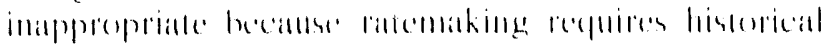

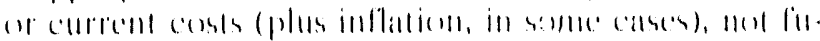

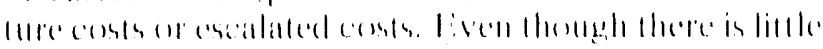

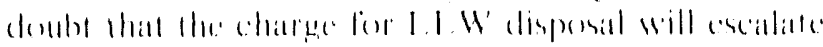

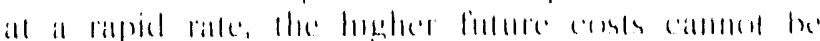

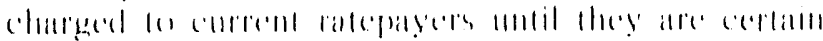

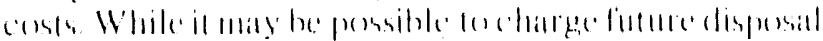

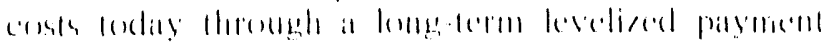

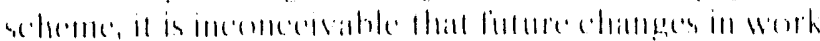

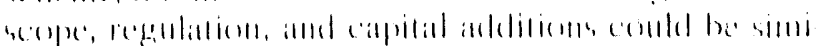

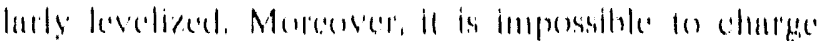

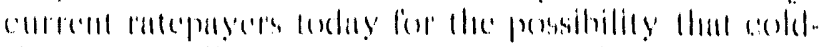

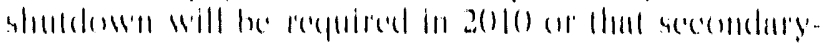

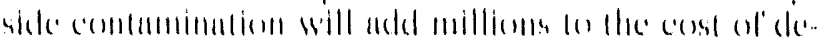

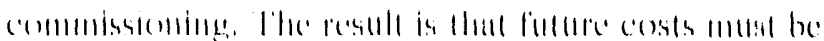

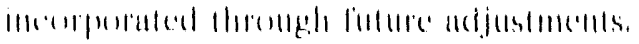

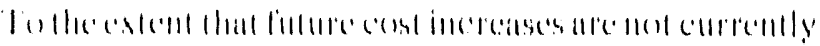

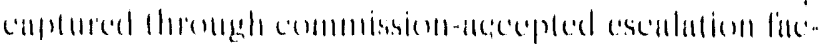

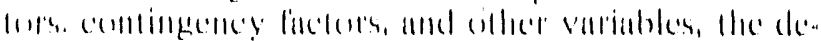

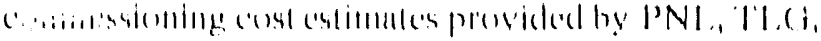

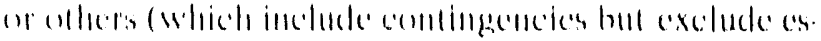

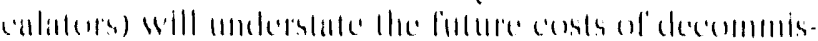

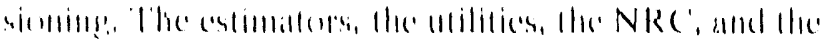

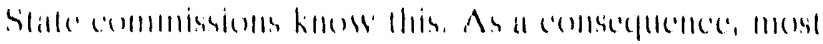

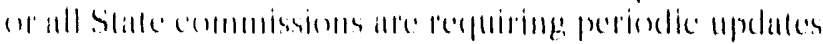

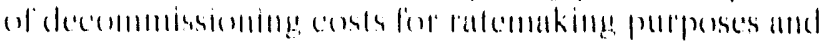

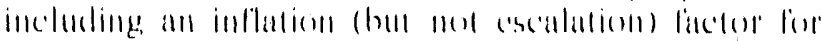

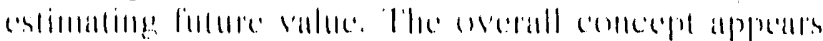

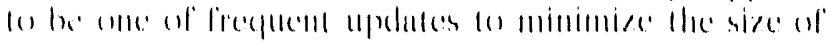

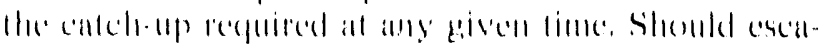

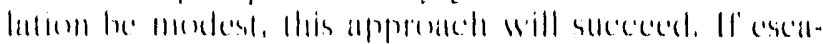

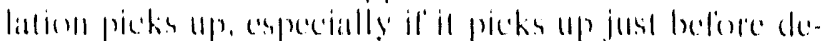

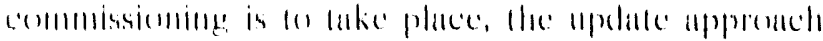

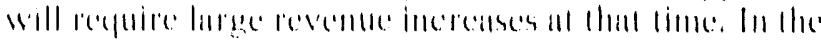

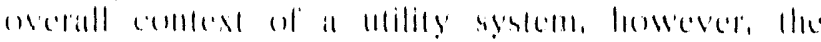

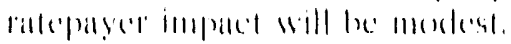

\section{Future Developments}

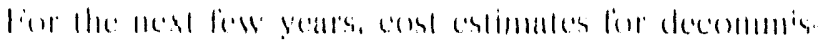

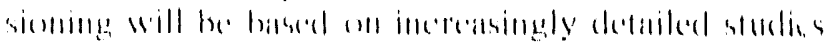

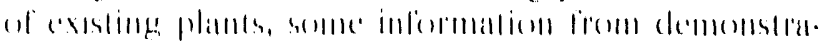

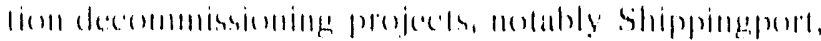

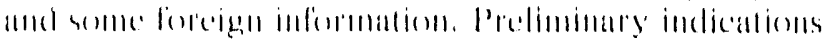

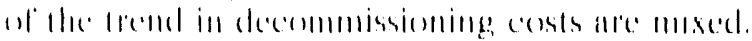

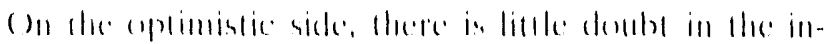

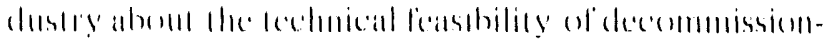

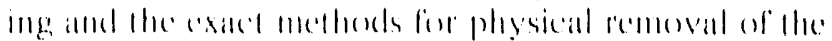

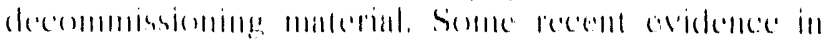

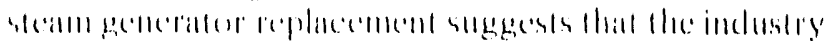

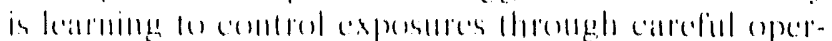

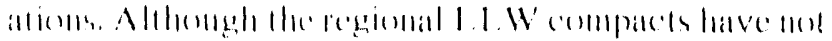

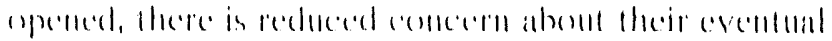

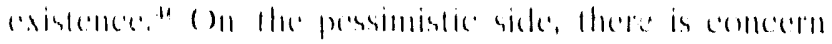

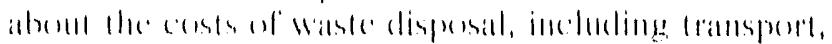

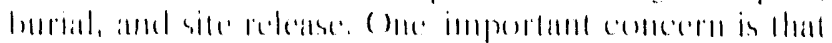

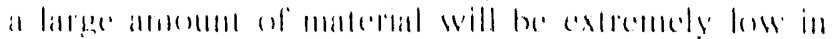

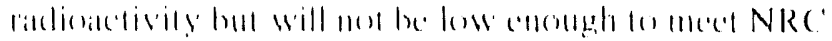

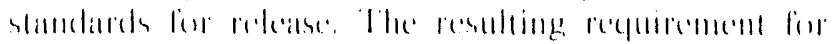

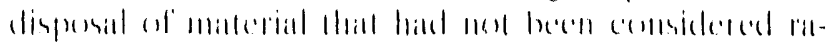

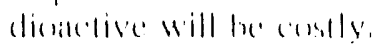

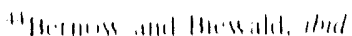

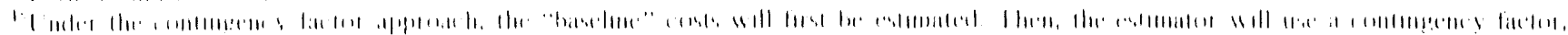

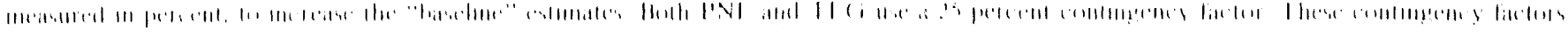

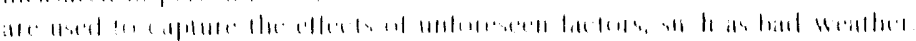

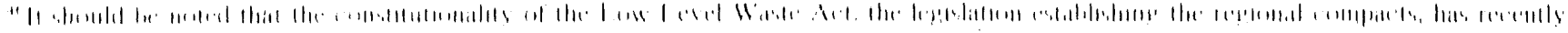

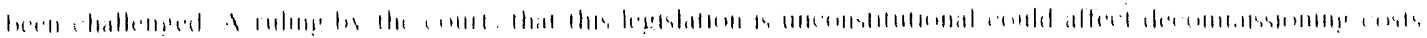


Another issue is the widely recognized but unpublicized difference between meeting State standards for decommissioning, i.e., site restoration, and meeting NRC standards, i.e., site release. The post-releatse costs for decommissioning, which are not part of the NRC estimates, could be significant.

A third potential problem is residual contamination on presumably nonradioacive structures and components. According to TLG, the cost of disposing of such material is not reflected in any PWR cost estimate but could run into the millions.

A fourth issue is worker productivity, especially (oward the end of the decommissioning project. Shippingport productivity declined sharply and workmen's compensation claims increased sharply with 6 months $t 0$ go on the project. It may be necessary to increase sharply the pay of workers who would otherwise want to avoid working themselves out of a job.

\section{Global Nuclear R\&L Activities}

The nuclear industry i:; becoming increasingly international. This trend is evident in both the commercial and the governmental sectors. International and intercorporate agreements, mergers, and cooperation have led to sharing in research and development (R\&D) activities as well as in other arcas. Mariy of the arrangements are clearly commercial. However, cooperation for marketing often leads to shared research or joint development projects.

\section{Commercial Cooperation in the Private Sector}

The move toward cross-country cooperation is evident in the private sector. During 1989 and the early months of 1990, a number of agreements and mergers were announced. This process has permitted firms lo achieve economies by centralizing some of their major nuclear $R \& D$ projects and by eliminating competitive efforts.

One of the most active participants in this process has been ASEA Brown Boveri, Lad. (ABB), based in Zurich, Switzerland. ABB itself is the result of the 1988 merger of ASEA, a major Swedish electrical equipment manufacturer, with the Swiss concern of Brown Boveri to form the latrgest electrical equipment supplier in the world. ASLA-Atom, now a division of ABB called ABB-Atom, has been prominent in nuclear research and development since the 1950's. During the past year, ABB has pursued links to promote its nuclear business. With Westinghousi, ABB formed ABB Westinghouse Nuclear Services to supply nuclear services to utilities in Europe. ABB and Westinghouse also have a joint venture company to supply transmission and distribulion markets in the Americals and another joint venture, lnnovative Téchnologies Incorporated, to provide fuel and other services in the United States. In November, ABB merged with Combustion Engineering in anticipation of growth in the U.S. eommercial niclear plant markel during the next decide. The new U.S. nuclear division of the combined companies is now called ABB Combustion Engineering Nuclear Power. ABB also has a joint venture with United Engincers, the U.S. architecture-engineering firm, to market the ASEA-Atom PIUS reactor in the (inited States. $A B B$ and Siemens (West Germany) recently formed a joint marketing company, HTR-GmbH, to sell highcemperature gass-eoled reactors in Europe. In 199), ABB signed agreements or held discussions with power generation companies and equipment mantafaturers in Italy, Spain, and Poland.

ABB is not the only foreign company linking with U.S. manufacturers. Babeock and Wileox has a joint venture with Framalome (France) for services in North America and another with Nuclear Power International, the PWR design and marketing joint venture formed by Framatome and Siemens, for marketing nuclear technology globally. General Electric and its Japanese partners (Hitachi, Toshiba, and the Tokyo Electric Power Company (TEPCO)) have develoned an advanced boiling-water reactor (ABWR) design. TEPCO has already plated an order for two of these 1,350-MWe ABWRs. General Electric is also engaged with its international partners Ansaldo of Italy, Hitachi and Toshiba of Japan, and KEMA/NUCON of the Netherlands, in the design of a simplified $600 \mathrm{MWe}$ boiling-vater reactor (SBWR). Westinghouse and its Japanese partners, Mitsubishi and Kansai Electric, are jointly developing a 1,3()()-MWeadvaneed pressurizedwater reactor (APWR). Although no orders have yet heen placed, a sale to Kansai is anticipated. Westinghouse and Mitsubishi are engaged in another joint project to deveiop an advanced simplified reactor for the Japan Atomic Power Company.

In Eastern Europe, Bechtel has a contract with Transelektro Foreign 'Trading Company to supply information and materials for managing complex nuclear activities to the Hungarian Electricity Board and the Paks Nuclear Power Station Company in Hungary. Siemens/Kraftwerk Union (West Germany) contracted to supply reactor loose-parts monitoring technology systems to Atomenergoexport (AEE) for PWRs operating in the Soviet Union. Two West German companies (Prenssenclektra AG and Bayernwerk AG) announced their intention fo form joint ventures with several organizations in the German Demereratic Republic (CiDR), including VE Kombinal Kernkraftwerke Bruno Leuschner, operator of the Nord nuclear plant in the Greifswald area. Electricite de France (butr) signed a service and enginecring contract with the Ministry of Nuckear Energy and Industry of the Soviet Inion. Skoda (Crechosloviatia) is secking 
a partner in Western Europe for two new units at the Temelin nuclear site.

\section{International Cooperation}

Japan Nuclear Fuel Industries (JNFI) signed an agreement to exchange information on low-level waste disposal with the United Kingdom's Nirex radioactive waste agency. JNFI also has agreements with the European national agencies UKAEA (United Kingdom Atomic Energy Agency), CEA (Commissariat a l'Energie Atomique of France), and SKB (SvenskKmbrnlehantering AB of Sweden). Japan has collaborated with Belgium for a number of years in research and development on nuclear fuels. Several new projects are in the planning stage. The Soviet Union signed a technology transfer agreement with EdF in December 1989. In November, the Soviet Union signed an agreement on nuclear cooperation with Brazil including technology transfer for small reactors and fast breeder reactors (FBRs). The cooperation will be at the government level as well as between engineering associations in both countries. The Soviet Union and the European Community also signed a bilateral agreement that includes exchange of scientific and technical information on nuclear energy. West Germaiy and Brazil will continue their agreement for nuclear cooperation for 5 years. However, there was opposition to this extension in both countries and Brazil's financial problems will limit the scope of cooperation.

European utilities are funding a common effort to develop a European Fast Reactor (EFR). The collaboration is coordinated through an informal operation called EFR Associates. The participating utilities are EdF, Nuclear Electric (UK); Preussenelektra and Rheinisch-Westfaelisches Elektrizitaetswerk (FRG), and Ente Nazionale per L'Energia Elettrica (Italy). The French, British, and West German partners are providing almost all the financial support since Italian participation is limited by the current nuclear moratorium in Italy. An agreement signed early in 1989 calls for collaboration on resedrch and development, development of a joint reactor design, and sharing of other scientific information. The shared R\&D permits the three active eountries to realize savings becauss research is split among the participants. The French are working on core physics; the British are concentrating on core mechanics; and the Germans are responsible for work on core cooling.

\section{Global Nuclear R\&D Projects}

The momentum continues toward internationalizing all nuclear research and development activities since such work is expensive. Shared projects and information reduce costs and eliminate duplication of effort. Public concern for safety in commercial nuclear operations demands extensive testing during each phase of technical development. International cooperation can allow accumulation and documentation of test experience more rapidly, which also can reduce costs.

The contraction of the market for commercial nuclear reactors has reduced the number of active firms committed to nuclear development. Even a large firm hesitates on making a full commitment to risky investment in nuclear R\&D because of the uncertainties about a revival in commercial nuclear plant orders and because of the difficulty of proving a new plant or component safe enough to be publicly accepted. By combining, through mergers or joint ventures, companies can reduce their individual investments and insure that there will be fewer competing new developments. At the national level, the same economic considerations promote collaborative research. Western Europe, moving foward econonic union in 1992, is also moving toward unified scientific and technical efforts. Japan wants to link its nuclear research to international efforts in order to make its nuclear industry internationally competitive. U.S. companies want to maintain commercial viability in Europe and Asia where the commercial nuclear sector is likely to expand. Economics is driving nations and firms to look at commercial nuclear power in a global way and is promoting international R\&D. 


\section{International Commercial Nuclear Power}

\section{Introduction and Current Status}

The 1990 edition of this report has been organized somewhat differently than previous CNe reports due to political developments in Eastern Europe during the Fall of 1989. The countries in this region are now attempting to create, within a revised political structure, an economy that embodies at least some features of western market economies. Therefore, EIA has eliminated a separate appendix for discussion of commercial nuclear power programs in countries that have or had centrally planned economies and combined them with other foreign countrics in Chapter 5 of this report. However, the countries added to Chapter 5 are not included in the projections of Chapter 4 because of insufficient dala.

For the countries with free market economies (FME), nuclear-generated electricity continued to grow in 1989. The number of operable nuclear generating units in FME countries increased from 340 in 1987 10 349 in 1988 and 355 in 1989. Total FME nuclear generation in 1989 reached a level of $1,557.7$ net terawathours (TWh), compared with 1,523.2 net TWh in 1988 (Table 2(3). This represents an increase in generation of 2.3 percent. (Neither Italy nor Mexico generated electricity from theif nuclear plants in 1989.)

Twenty FME countries produced nuclear-genenated electricity in 1989. The United States, France, Japan, West Germany, Canada, and United Kingdom ac: counted for over 80 percent of the total FME probluction. Three countries produced 50 percent or more of their electricity from nuclear power: France (74.6 percent), Belgium (60.7 percent), and South Korea (50.2 percent).

The United States led all FME countries in bringing new units on line in 1989 with three units entering ser- vice. Six countries followed with one unt each. Total FME operable nuclear capacily increased by 2.3 percent over the level in 1988, (1) 27.3.6 GWe at the end of 1989." Table 21 shows that in 1989 U.S. nuclear capacity aceounted for about 38 pereent of the total operable nuclear capacity in countries belonging to the Organization for Economic Cooperation and Development (OECD) th and about 36 percent of total operable nuclear capacily in all FME countries. (Outside the United States, operable units are defined as those that have generated electricity to the grid.) In 1989 , the overall nuclear share of net electricity generation in the OECD countries was 22.8 percent, compared with 2.3 .5 percent in 1988." Appendix F lists all the operable foreign FME nuclear units as of December 31,1989 .

Table 22 shows the status of the foreign FME nuclear construction pipeline as of December 31, 1989. One unit was added to Japan's construction pipeline since last year's report. Even as total nuclear operable catpacity was increasing, the amount of capacity in the construction pipeline continued to decrease, from 84.9 GWe in 1987 10 74.8 GWe in 1988 and 64.5 GWe in 1989. The decline can be attributed mostly to the completion of six units and very few new orders.

Figure 4 shows the extent of completion of nuclear units in the foreign FME construction pipeline for the end of years 1985 through 1989. In 1989, 54 percent of the units in the construction pipeline were 25 percent or less complete. The proportion of units that were between 26 and 75 percent complete increased from 15 to 21 percent. The proportion of units in the pipeline that were 76 percent or more complete decreased to 17 percent.

The continuing decline during the past several years in the number of units in the construction pipeline is due to several factors. First, countries continuc to review the role of nuclear power in their energy plans, in the wake of the 1986 Chernobyl 4 accident in the

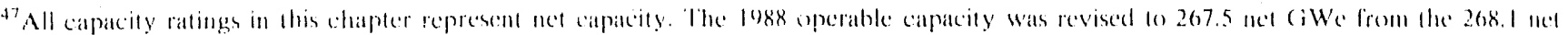
(iWe published in last year's report.

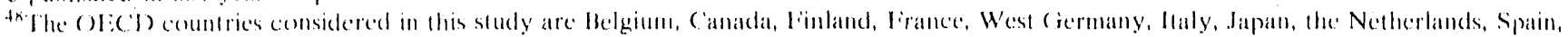

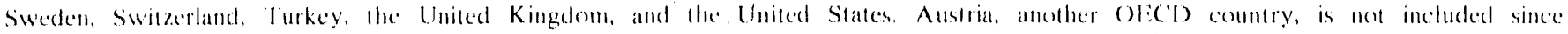

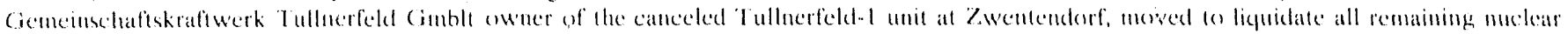
aseets in 1989 and neared a fermal decesson ter convert the plant to a gas-fired station.

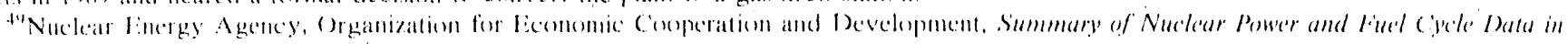

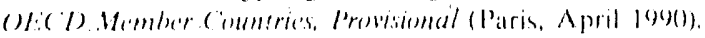


Soviet Union. Second, some countries have overtuill generating capacity, due to highly optimistic forecasts of demand. As a result of slower than expected ecenomic growth in the 1980's, those forecasts have not been realized. Third, some countries with sufficient calpacity 10 moet near-term demand are reassessing their finture expansion plans, particularly with respect to conservation programs. Thus, most countrics have delayed the eonstruction of current projects and the placement of new nuclear orders. Appendix $G$ lists the units in the muclear construction pipeline in foreign LML countries, inoluding informution on the stage of completion for each unit as of becember 31, 1989.

\section{Table 20. FME Operable Nuclear Power Plant Statistics, 1988 and 1989}

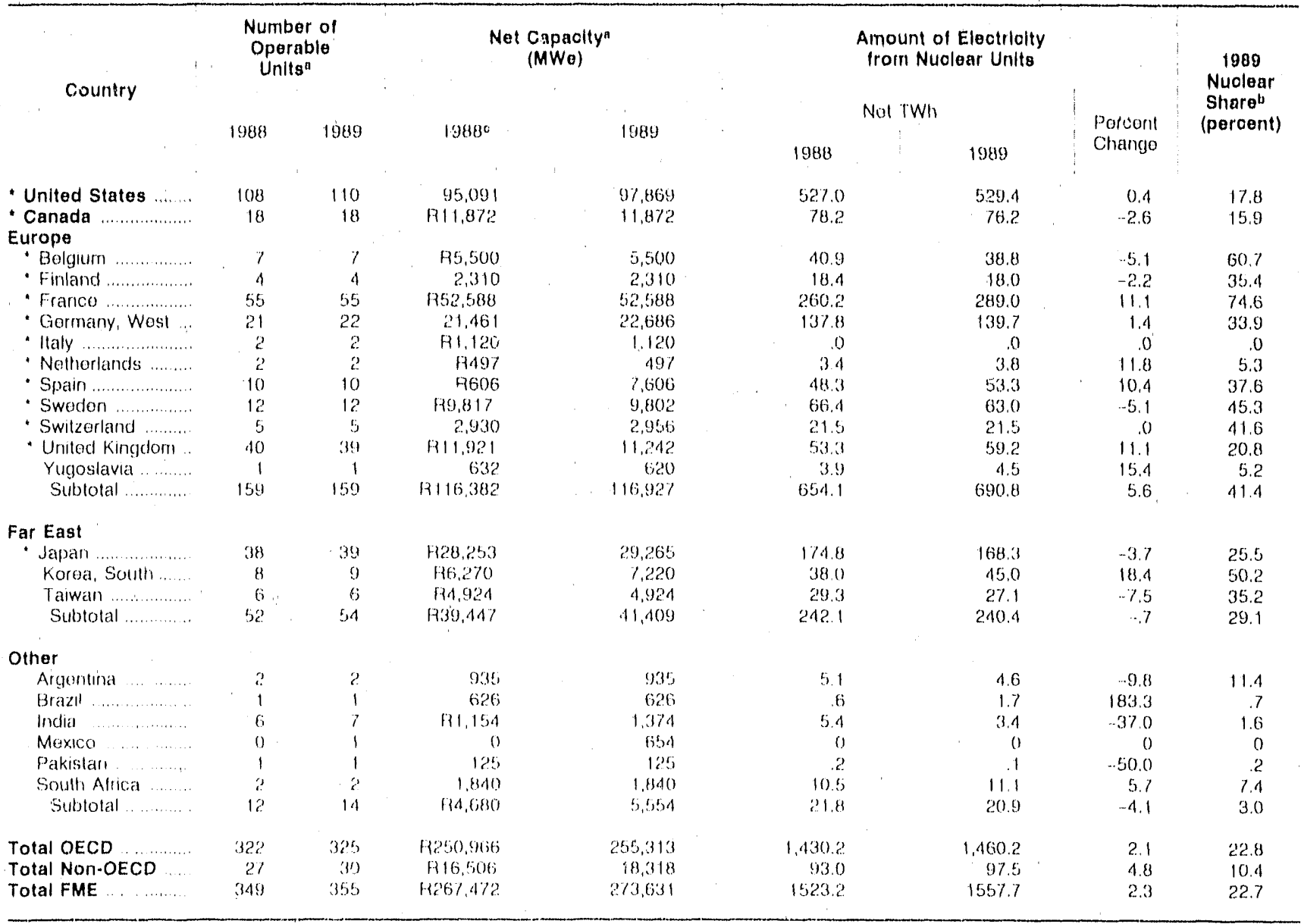

a For all non-United States units. operable units are those that have generated electricity to the grid. An operable unit in the United States is one that has been issuod a full power liconse from the U.S. Nuclear Regulatory Commission. For all non. United Statas units, capacity is the not dosign electrical rating. For United States unils, napacity is net summer capability. Capacitios of individual units aro subject to reratings from year to year. Soe dofinltions of capacties in glossary.

b Not oloctricity generatod from ruclear power generating units as a percentage of nol olectricity gonerated from all sources. The sources for nu. clear goneration are the OECD and tho IAEA for the OEC:O and non-OECD countries, respectively. The nuciear share of utility-gonerated electricity for the United States was 19,0 percont.

- Some nuclear units were reraled to refloct moro curront data.

FME Free Market Fconomies

- Member of the Organization for Economa: Cooporation and bevelopment

NA. Not Available:

A. This hgure is a reviston of the figure published in Commencial Nuctear Hower 1989; Prospects for the United States and the World, DOE. EIA. $0438(89)$ (Washmiton. DC, September 1989)

Sources: 1988-Energy Information Admonstration, Commoncial Nuclea Fower 1989: Prospects for the United States and the World. DOE/EIA 0438(89) (Washington. DC: Soptember 1989). 1988 United States Capacity- Energy Intormation Administration, Monthly Energy Aoview. Decomber 1988, DOE/EIA-0035(88/12) (Washington, [OC, March 19839), and Decomber 1988, DOE/F.IA-0035(88/12) (Washington, DC, March 1989); 1988 Operable Units and Capacity... Appendices $C$ and $f$ of this report: 1989 Generation-.. The source of nuclear genteration is tho Organization for Economic Co. operation and Development (OFCD), Nuclear Energy Agency (NEA), Summary of Nuclear Powor and Fuel Cys/e. Data in OECD Momber Countries, Provi.

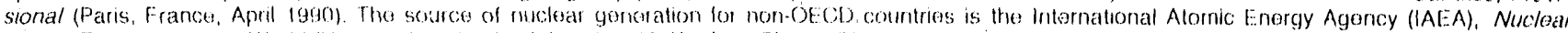

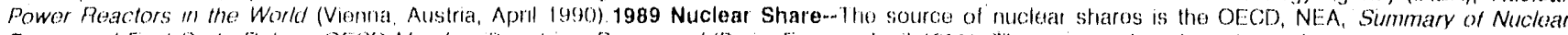

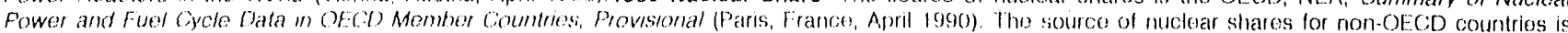
the IAEA, Neckar Power Beators in the Workt (Vionria, Austra, April 1990). 
Table 21. FME Operable Nuclear Capacity as of December 31, 1989

\begin{tabular}{|c|c|c|c|}
\hline Countries & $\begin{array}{l}\text { Net Nuolear } \\
\text { Capaolty } \\
\text { (aWo) }\end{array}$ & $\begin{array}{l}\text { Peroent of } \\
\text { Total OECD } \\
\text { Capaoity }\end{array}$ & $\begin{array}{l}\text { Poroont of } \\
\text { Total FME } \\
\text { Captiolfy }\end{array}$ \\
\hline \multicolumn{4}{|l|}{ OECD } \\
\hline Unitod Statos & 97.9 & 36.3 & 36,8 \\
\hline Forelgn ................... & $16 \% .4$ & 01.7 & 57.5 \\
\hline Total OECD & 255.3 & - & 94.3 \\
\hline NOn-OECD & 18.3 & - & 6.7 \\
\hline Total FME & 273.6 & $\ldots$ & . \\
\hline
\end{tabular}

\section{Table 22. Status of Foreign (FME) Commercial Nuclear Generating Units in the Construction Pipeline as of December 31, 1989}

\begin{tabular}{|c|c|c|c|c|c|c|c|c|c|c|}
\hline \multirow{3}{*}{ Country } & \multicolumn{10}{|c|}{ Percentage of Construction Completed } \\
\hline & \multicolumn{2}{|c|}{01025} & \multicolumn{2}{|c|}{26 to 50} & \multicolumn{2}{|c|}{51 to 75} & \multicolumn{2}{|c|}{7610100} & \multicolumn{2}{|c|}{ Tolal } \\
\hline & $\begin{array}{l}\text { No. of } \\
\text { Units }\end{array}$ & $\begin{array}{l}\text { Net } \\
\text { MWe }\end{array}$ & $\begin{array}{l}\text { No. of } \\
\text { Units }\end{array}$ & $\begin{array}{c}\mathrm{Nal} \\
\mathrm{MW}\end{array}$ & $\begin{array}{l}\text { No, of } \\
\text { Units }\end{array}$ & $\begin{array}{l}\text { Nol } \\
\text { MWo }\end{array}$ & $\begin{array}{l}\text { No. of } \\
\text { Unils }\end{array}$ & $\begin{array}{c}\text { Net } \\
M W 0\end{array}$ & $\begin{array}{l}\text { No. of } \\
\text { Unils }\end{array}$ & $\begin{array}{l}\mathrm{Nol} \\
\mathrm{MWe}\end{array}$ \\
\hline • Canada ................... & 0 & 0 & 1 & 881 & 1 & 881 & 2 & 1,762 & 4 & 3,524 \\
\hline \multicolumn{11}{|l|}{ Europs } \\
\hline - France ........................ & 1 & 1,455 & 0 & 0 & 4 & 5,550 & 4 & 5,240 & 9 & 12,245 \\
\hline - Germany, Wost ... & 0 & 0 & 0 & 0 & 0) & 0 & 1 & 295 & 1 & 295 \\
\hline • |laly ........................ & 0 & 0 & 0 & 0 & 2 & 1,964 & 1 & 40) & 3 & 2,004 \\
\hline - Spain ......................... & 4 & 4.002 & 0 & 0 & 1 & 975 & 1 & 975 & 6 & 5,952 \\
\hline - Switzerland .......... & 1 & 1,140 & 0 & 0 & 0 & 0 & 0 & 0 & 1 & 1,140 \\
\hline " United Kingdom .. & 1 & 1,200 & 1 & 1,175 & 0 & 0 & 0 & 0 & 2 & 2,375 \\
\hline Subtotal ..................... & 7 & 7,797 & 1 & 1,175 & 7 & 0,489 & 7 & 6,550 & $2 ?$ & 24,011 \\
\hline \multicolumn{11}{|l|}{ Far East } \\
\hline - Japan .......................... & 20 & 20,748 & 3 & 3,100 & 1 & 280 & 2 & 1,646 & 26 & 25,774 \\
\hline Korea, South ....... & 2 & 1,850 & 0 & 0 & 0 & 0 & 0 & 0 & 2 & 1,850 \\
\hline Taiwan ..................... & 2 & 1,900 & 0 & 0 & 0 & 0) & 0 & 0 & 2 & 1,900 \\
\hline Subtotal .............. & 21 & 24,498 & 3 & 3,100 & 1 & 280 & 2 & 1,646 & 30) & 29,524 \\
\hline \multicolumn{11}{|l|}{ Other } \\
\hline Argentina ................ & 0 & 0 & 0 & 0 & 1 & 692 & 0 & 0 & 1 & 692 \\
\hline Brazil ....................... & 0) & 0 & 1 & 1,229 & 1 & 1,229 & 0 & 0 & 2 & 2,458 \\
\hline Egypt & 2 & 1,800 & 0 & 0 & 0 & 0 & 0 & 0 & a. & 1,800 \\
\hline 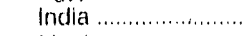 & 4 & 880 & 1 & 220 & 1 & 220 & 1 & 220 & 7 & 1,540 \\
\hline Mexico ……................ & 0 & 0 & 1 & 6554 & 0 & 0 & 0 & () & 1 & 654 \\
\hline Pakistan ................. & 1 & 300 & 0 & 0 & 0 & 0 & 0 & 0 & 1 & 300 \\
\hline Subtotal ................ & 7 & 2,980 & 3 & 2,103 & 3 & 2.141 & 1 & 220 & 14 & 7,444 \\
\hline Total OECD & 27 & 28,545 & 5 & 5,156 & 9 & 9,650 & 11 & 9,958 & $5 \%$ & 53,309 \\
\hline Total Non-OECD ...... & 11 & 6,730 & 3 & 2,103 & 3 & 2.141 & 1 & 220 & 18 & 11,194 \\
\hline Total Forelgn FME & 38 & 35,275 & 3 & 7.259 & 12 & 11,791 & 1 ? & 10,178 & 70) & 64,503 \\
\hline
\end{tabular}

- OECOO country member.

OfCD Organization for Econornic Cooperation and Development

FME Freo Market Economios

Sources: Appendix $G$. 
Figure 4. Status of Foreign (FME) Commercial Nuclear Generating Units in the Construction Pipeline as of December 31, 1989

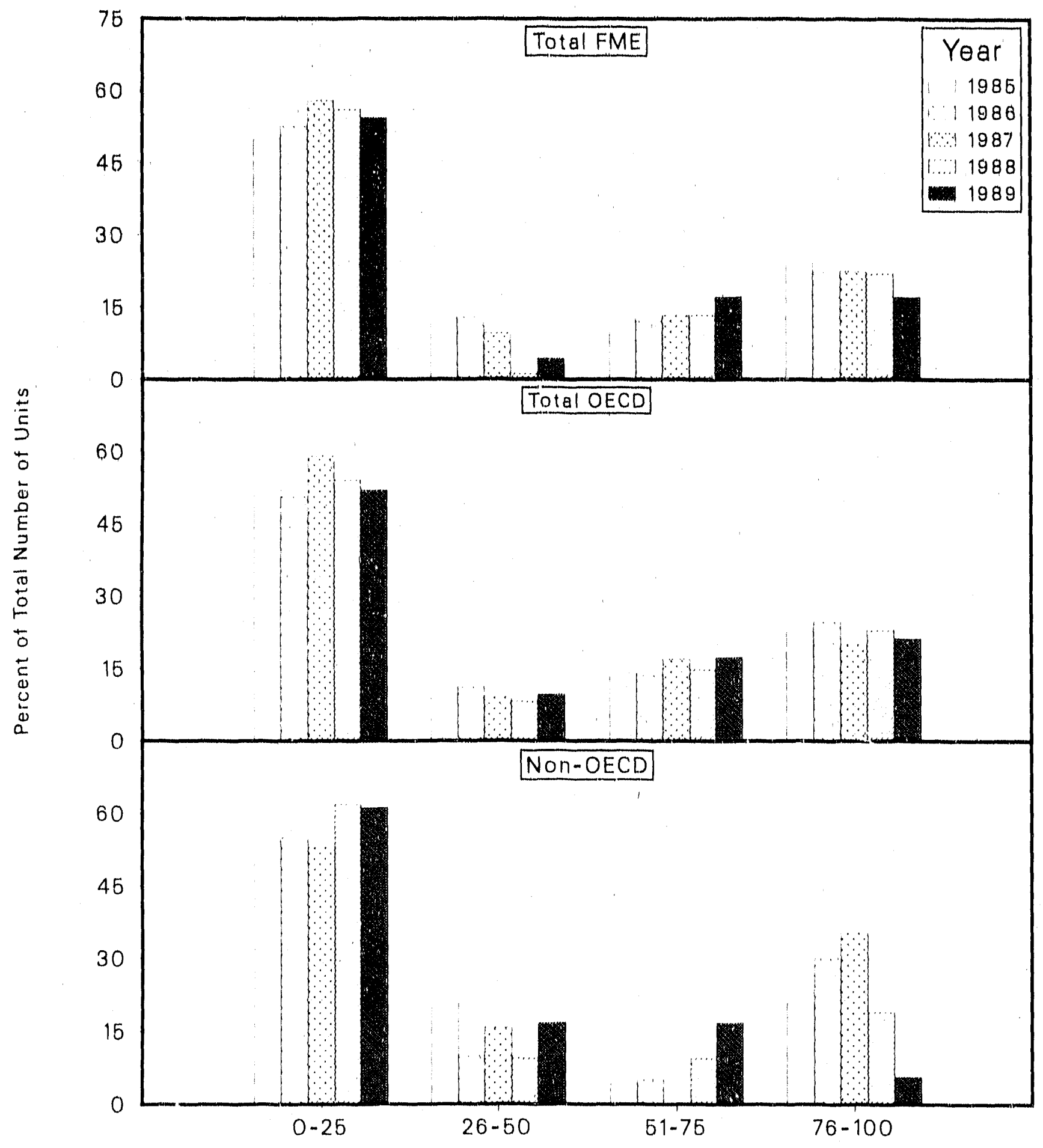

Percentage of Construction Completed

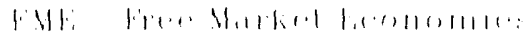

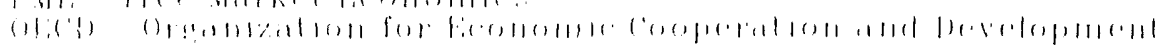

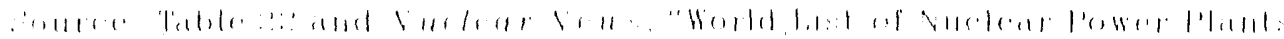


In 1989, the Orgunzation for Economic Cooperinton and Development (OECD) published the results of " study jointly undertaken by the OECD Niclent En. ergy Agency and Intermational linergy Agency on the: projected eosts of generating celectricity, "Eighlecen OECD countrides and live non-OBCD countrles (under the ausplees of the Intermutional Alomic Energy Agency) purticipated in the stady. Using commonon red. erence assumptions of a $3(0)$ year life and a 72 percesul levelized lifethe capmetty factor, and an anmonl discount rate of 5 percent, the following results were reported. For lifetime baselond operation, nuclear power plants were projected fo have an ecomemice advantage over alternative baselond generating options in Japan, a majority of countries in OECD Europe, in regions of North Americu distunt from coalfields, and in the non-OECD countries, except in the low-eost coul regions of Brazil, China, and India.

The number of operable units in comntrios with regulated markel and eentrally planned ecomomies, RME: and CPE, respectively, decreased from 72 in 1988 (o) 66 in 1989 ('Table 23). Total RME and CPE nuclear generalion, in 1989 reached a level of 274.2 gross TWh compared with 276.3 in 1988. This represents a decrease: in gencration of 0.8 percent.

Four RME and one CPE countries prodiced nucleargenerated electricity in 1989. The Soviet Union accounted for over 75 percent of the lotal RME and ClE production. There countries produced 25 pereent or more of their electricily firom molear power: Hengan'y

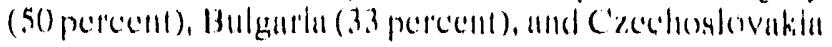
(28 percecellt).

\section{Outlook for Countries with Free Market Economies}

\section{Methodology}

Operable nuclear capacily for forcign FME countrics through 20 ) 0 is projected in two steps. Initially, " "collstruction pipeline" unalysis, as discussed in Appendix B, is ased co project capucity on the basis of units in operation and lhose under construction or planned llat cant reasomably be expected to be completed during the projection pretiod. Becaluse the constritetion pipeline is exhansted in different years for different countries, the filtst step in the projection proceses involves identifying the year through which current and planned nuclear construction projects could be completed for ench FME country. Appendix G lists these years and contains unit-specific information and estimates of operable dates within the s-year projection intervals for each of the projection scemarios.

\section{Table 23. Nuclear Capacity and Generation in Countries with Regulated Market and Centrally Planned Economies as of December 31, 1989}

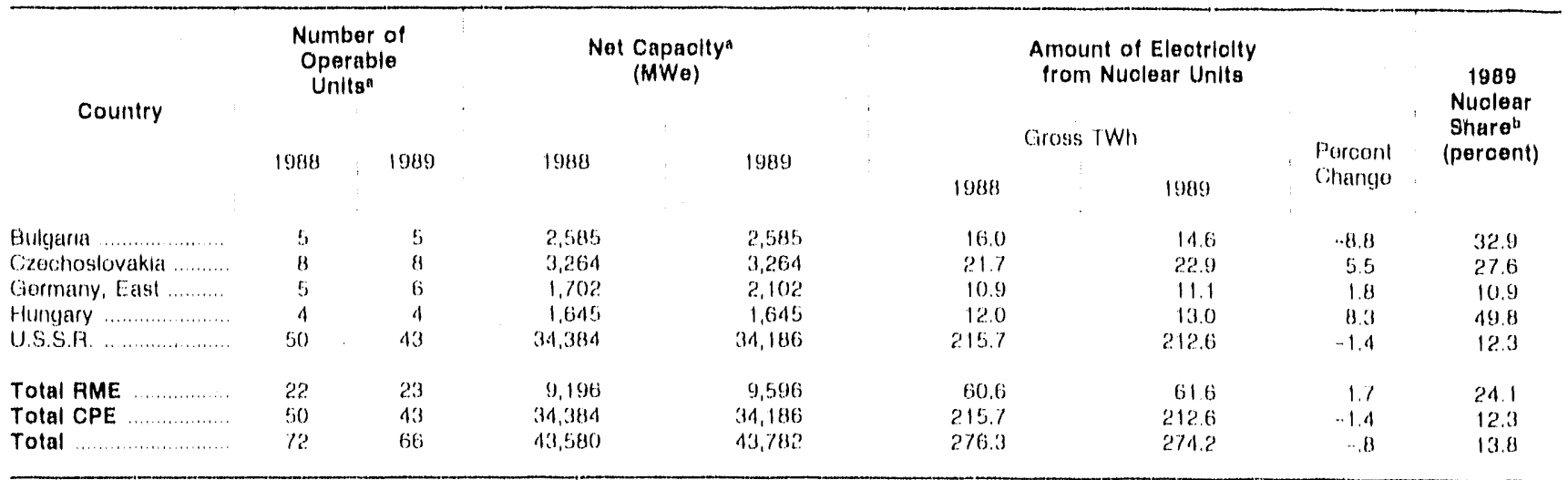

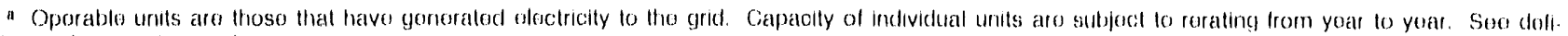
nitions of capacitios in glossary.

b Net olesctricity gonorated from nucieal power gonerating units as a perconlago of not olectricity genotatod trom all sourcos.

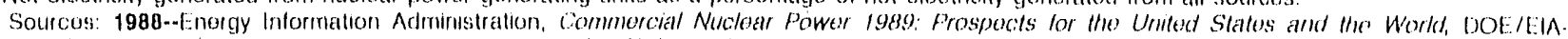

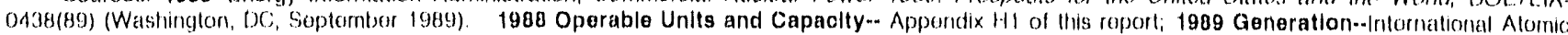

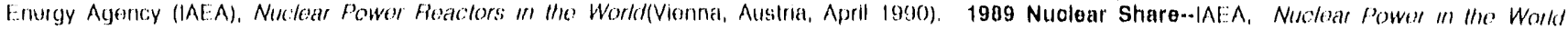
$(190())$.
}

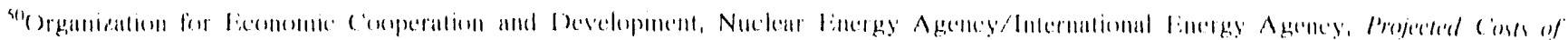

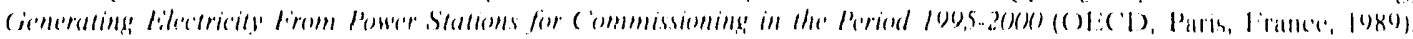




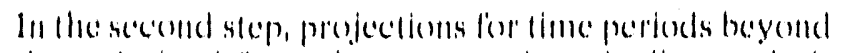

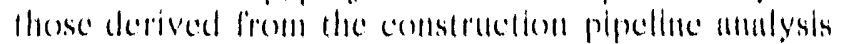
are bused on the World lulegraled Nuclear livalumilon System (WVINISS). (Appendix B describes lhe reacelon

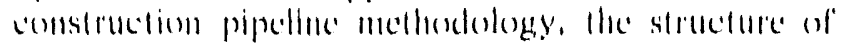

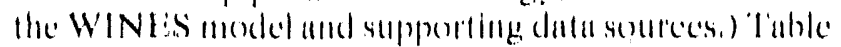

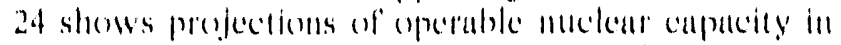

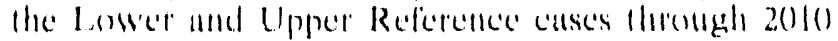
fin limlic comblrices.

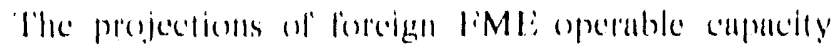
based on the comstraction pipelife apprench resule

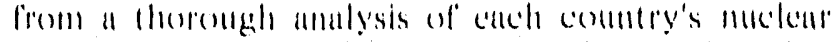

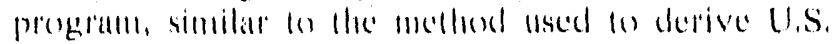

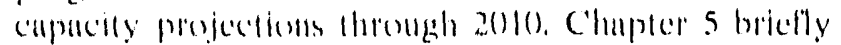
reviews active nacken prograns in individual liml:

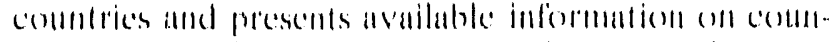

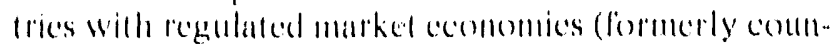

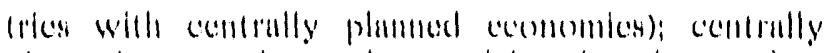

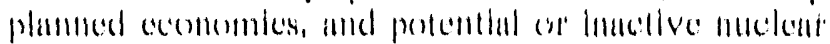

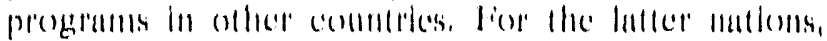

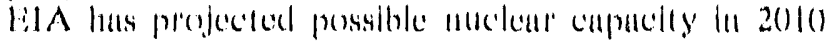

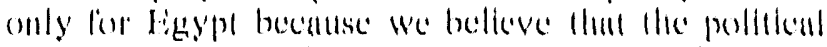

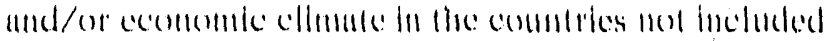
in Tuble 24 makes it mollkely that they will have op.

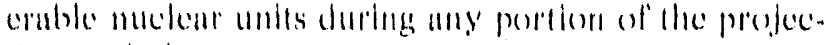
lion porient.

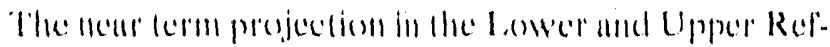

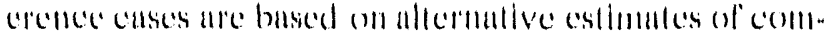

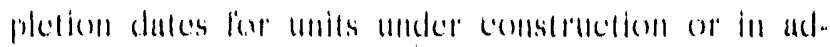
vanced planming stages. The expected completion dates

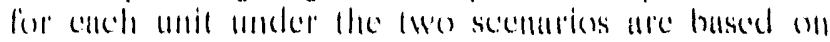

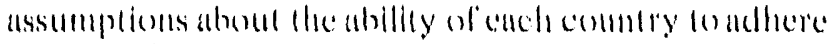
lo ils mucleur pregarams.

Table 24. 1985, 1989 FME Operable Nuclear Capacities and Projected Capacities for 1995, 2000, and 2010 (Nel Gigawatts-Electric)

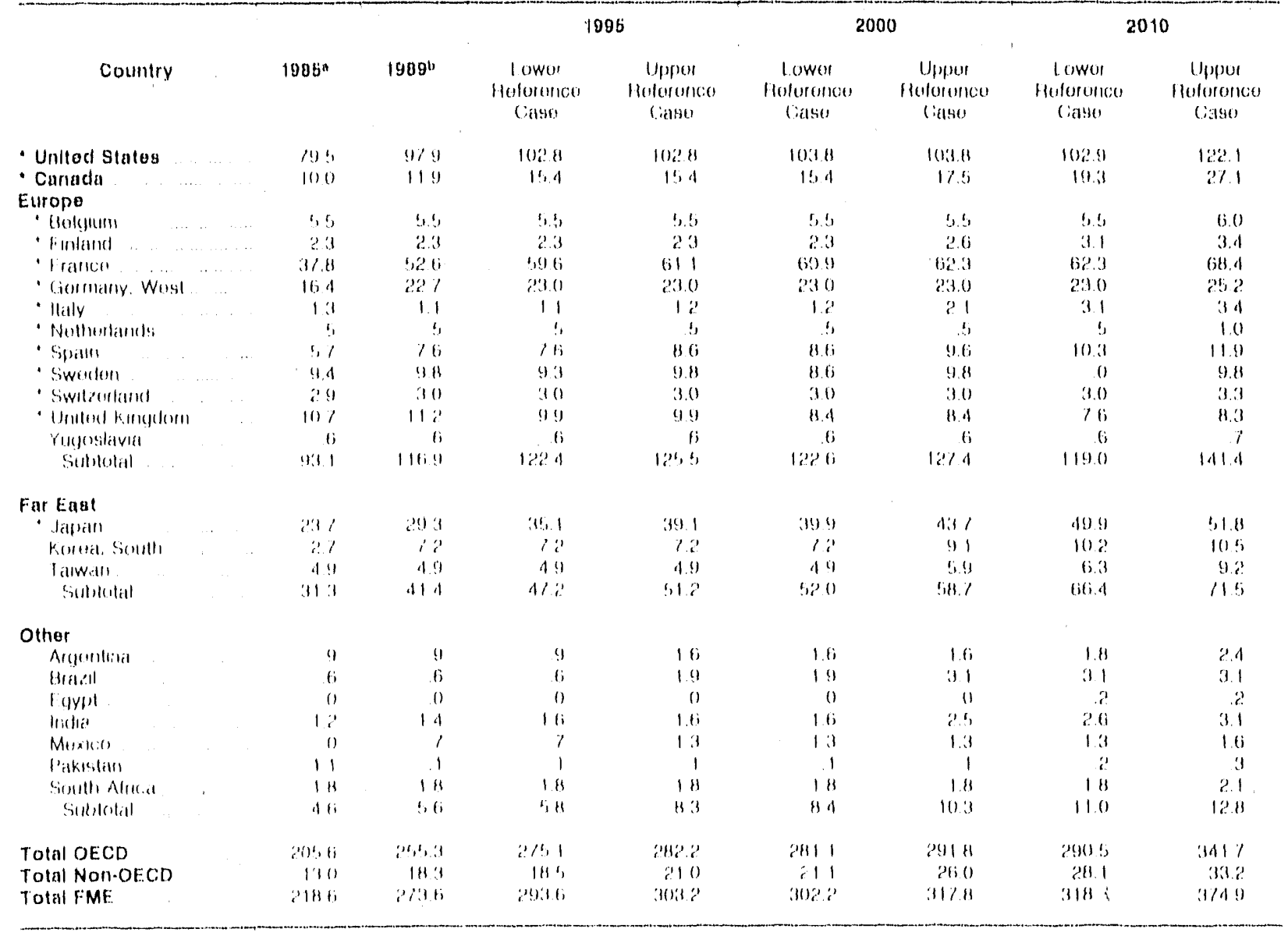

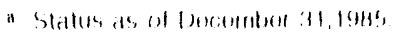

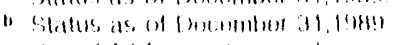

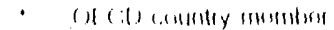

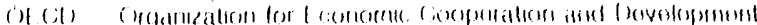

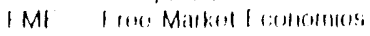

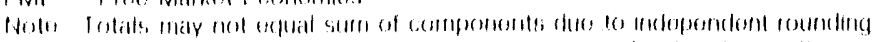

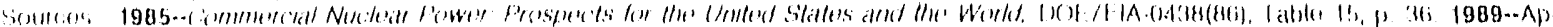

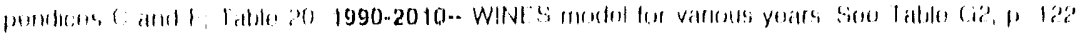




\section{WINES Model Parameter Assumptions}

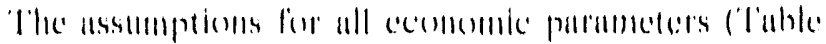

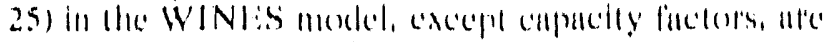

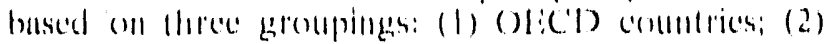

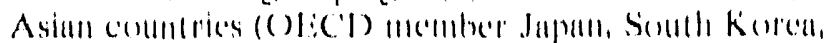

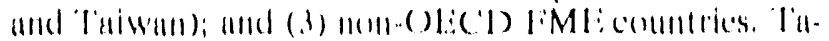

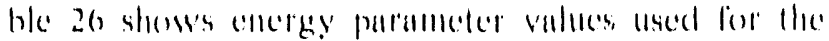

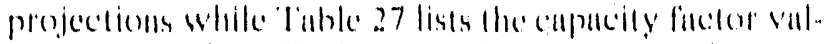

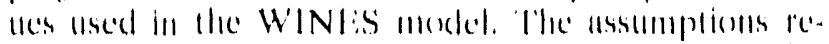

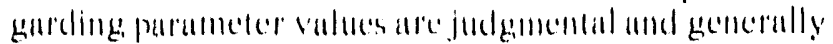

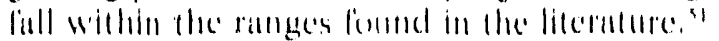

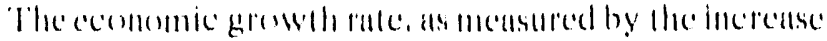

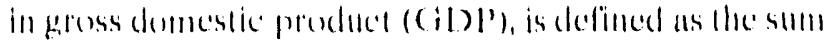

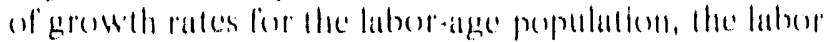
force participation fraction, and labor prodectivily. The grewelh rates for the labor-ige population are de-

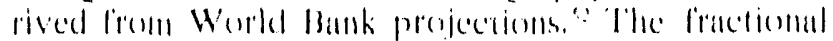

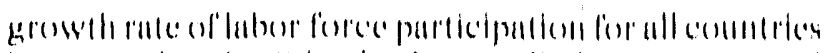

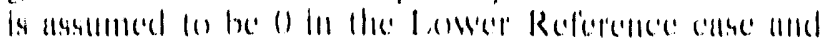

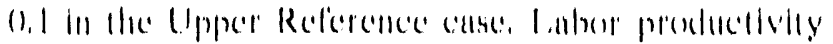

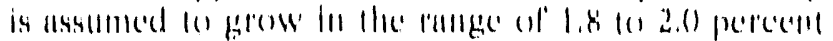

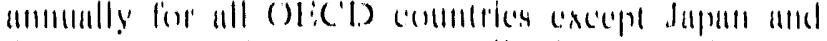

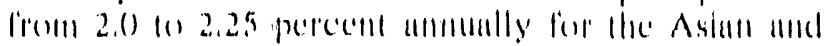

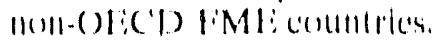

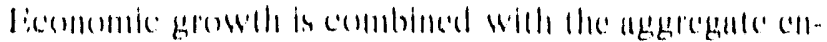

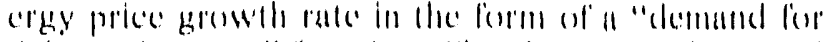

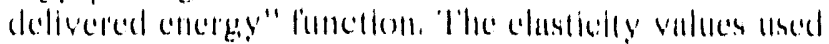

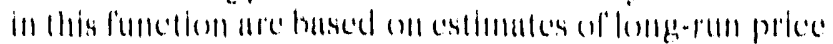

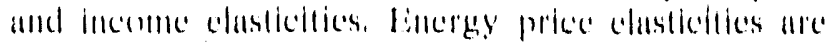

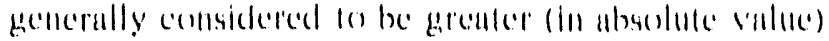

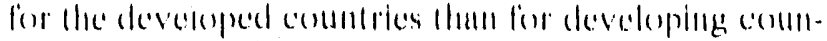

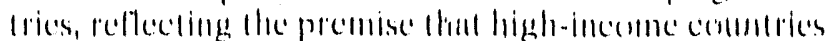

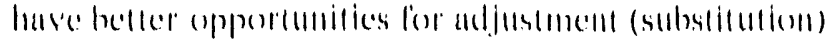
than de conuntries with relutively low incomes. Similarly, income clasticitien are genterally comsidered 10

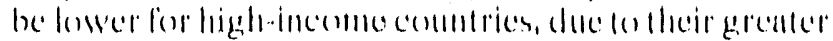

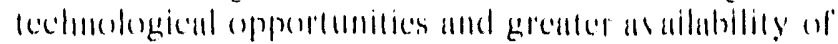

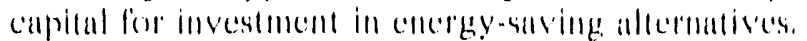

\section{Table 25. Economic Parameter Values Assumed in the WINES Model for Different Country Groups}

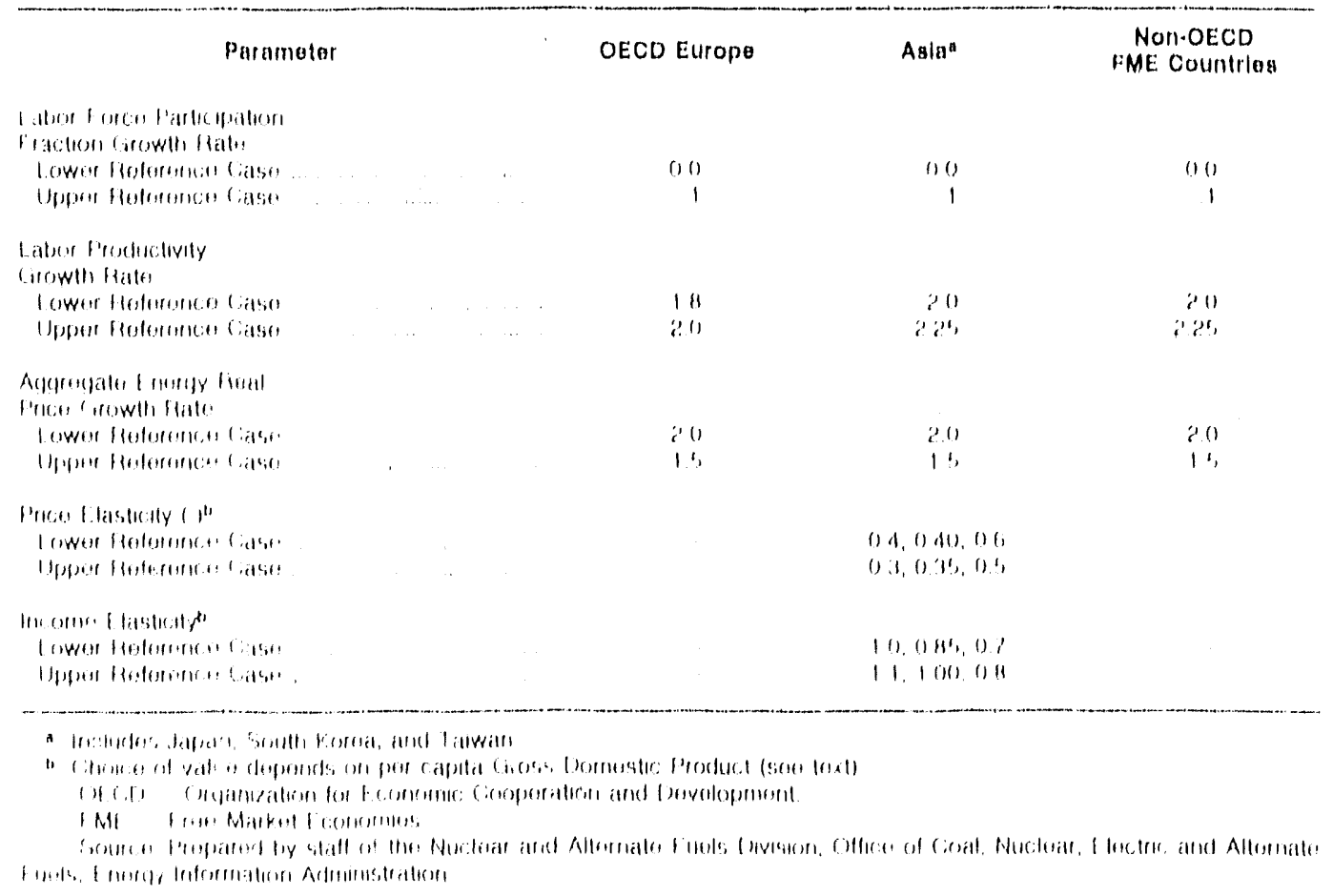

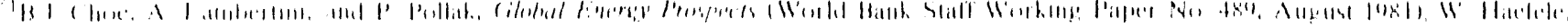

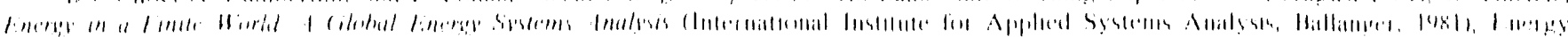

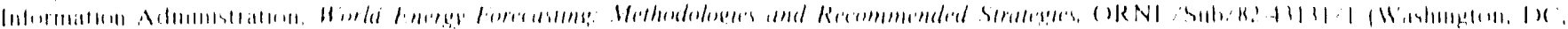

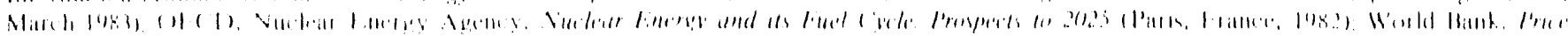

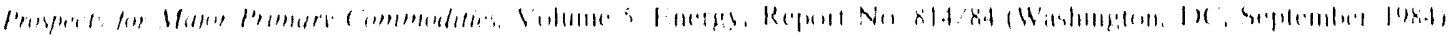

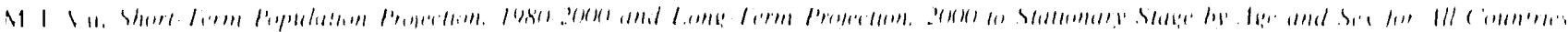

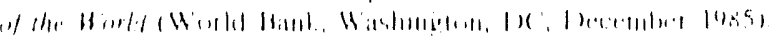




\section{Table 26. Energy Parameter Values Assumed In the WINES Model for Different Country Groups}

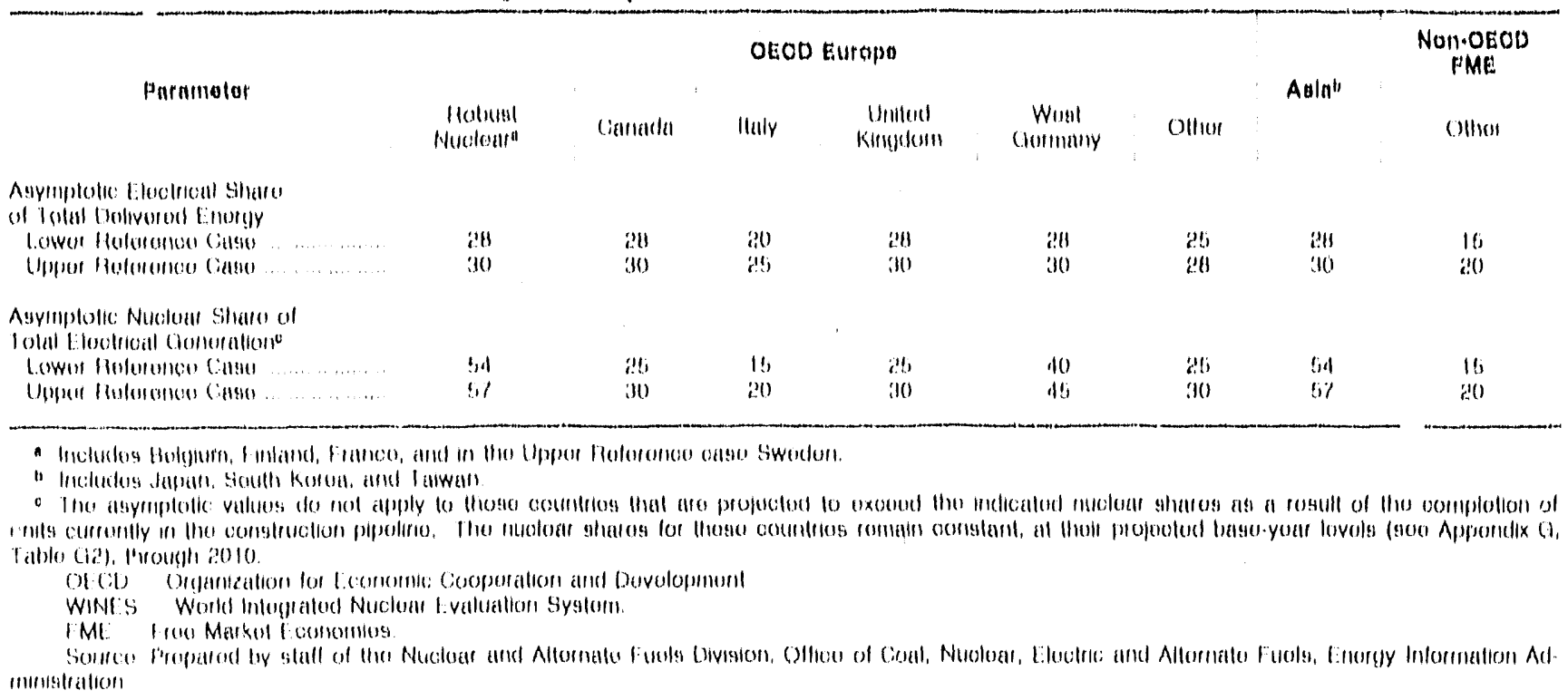

\section{Table 27. Capacity Factors for Commercial Nuclear Power Plants in FME Countries (Porcent)}

\begin{tabular}{|c|c|c|c|c|c|c|c|c|c|c|c|}
\hline \multirow{2}{*}{ Counitry } & \multicolumn{10}{|c|}{ Annual Capnolfy Fnotorsn } & \multirow{2}{*}{$\begin{array}{l}\text { Prolootlons } \\
\text { for tho } \\
\text { Yonr } 2010\end{array}$} \\
\hline & 1948,1 & 19iss & $10 H_{i}^{\prime}$ & $108: 1$ & 191614 & 10645 & $19 H 6$ & $1601 \%$ & $1918 B$ & 1040 & \\
\hline Arguonilléal & 76 & 90 & (i) & 61 & 80 & (ib) & 65 & (AB & 51 & 14 & $\theta !$ \\
\hline Holgyunn & $M 1$ & $(14)$ & 17 & 10 & 187 & $\mathrm{Ha}^{2}$ & 11 & 83 & $B G$ & (3) & 76 \\
\hline Hatal & & $"$ & & $1 "$ & 16 & 30 & $?$ & 17 & 0 & 28 & aij \\
\hline Cannalat & $H i ?$ & HII & H!! & $7 ! 1$ & 12 & 72 & $i 3$ & $7 \%$ & 17 & in & 75 \\
\hline $\mid$ !yyut & & $"$ & $\cdot$ & $"$ & & $" 1$ & & " & & $b$ & (36) \\
\hline | пाllams| & !i & $7: ?$ & $H_{i}^{\prime}$ & $H 7$ & $4 !$ & $(1)$ & $H !$ & $y{ }^{\prime}$ & 01 & (1) & 79 \\
\hline latrus! & lio & sil & in & ii? & 10 & 71 & 67 & 60 & 6,1 & $\left(i c^{\prime}\right.$ & 70 \\
\hline Coomentry, Woril & $t, t_{1}$ & (i) & 10 & 10 & 16 & $B 1$ & 713 & 15 & $7 /$ & $\theta 9$ & 70 \\
\hline Indelit $\ldots$ & $4 !$ & 11 & $\therefore$ & $: 111$ & 4.1 & 116 & 小 & 41 & $5 \%$ & 3 & (ib \\
\hline \|ally & 11 & $\because 1$ & 4,13 & bi? & fiil & $(3)$ & 74 & ' & 0 & 0 & filj \\
\hline Jupann & 1.1 & 00 & (3i) & $\theta i 1$ & 10 & 71 & 76 & 11 & 11 & 71 & 70 \\
\hline Kofora, somilh & iij & sfi & $1: 1$ & 60 & 10 & iii & 11 & H? & $6 i$ & 74 & $6 i$ \\
\hline Mexicin & & $"$ & & $b$ & & $"$ & & 1 & & $"$ & (i) \\
\hline Nolhonlanels & 90 & 111 & $\mathrm{Hid}$ & $/ 6$ & 81 & B? & $H H$ & $7 !$ & H!! & $H O$ & $7 !$ \\
\hline Pakirilun & $i$ & 10 & 7 & 19 & id & $a$ & 41 & 20 & 16 & (i & (ii) \\
\hline South Almsa & & $"$ & & $"$ & 69 & $: 17$ & 36 & 34 & (i) & 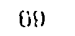 & 05 \\
\hline Spari ............. & 5,3 & 65 & $4 !$ & d7 & (j4) & 0.1 & 14 & 80 & 70 & HI & $0 ! 5$ \\
\hline . $\ldots \ldots \ldots \ldots \ldots \ldots$ & $(i)$ & 64 & 61 & 00 & 76 & 71 & 41 & 77 & 17 & 74 & 70 \\
\hline Switzorland & $8(1)$ & 115 & $\mathrm{HA}$ & 111 & $\mathrm{HH}$ & 116 & Hi,1 & B! & (1:) & $\| 1$ & Bij \\
\hline Talwan $\ldots . . . .$. & 13 & (i6; & bil & 66 & $\because$ & biti & (i) & 19 & (it) & $6 c^{\prime}$ & $6 ! j$ \\
\hline Turkoy & & $"$ & & $"$ & & 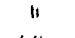 & & $"$ & & $"$ & $6 G$ \\
\hline 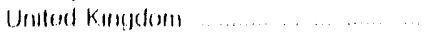 & 17 & 40 & 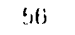 & !l & 10 & 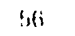 & $3 i$ & 64 & 56 & 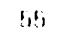 & $6 t_{j}$ \\
\hline 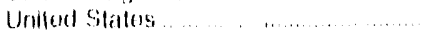 & $! s(i$ & ! $6 !$ & 67 & $6 i$ & siti & $6 H$ & 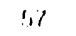 & ?il & 134 & 6r! & $8 \mathrm{BH}$ \\
\hline Yucjousiavia $\ldots \ldots \ldots \ldots \ldots$ & NA & NA & NA & NA & his & (30) & $(j !)$ & 17 & 71 & 11 & 6!i \\
\hline$\ldots \ldots \ldots \ldots$ & 60 & $6 r$ & (j) & lit? & 6id & $6 t^{\prime}$ & 66 & (is) & (is & 61 & 10 \\
\hline
\end{tabular}

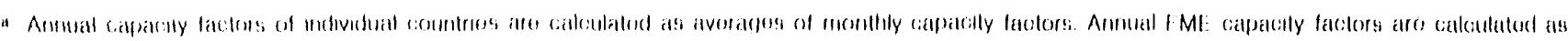

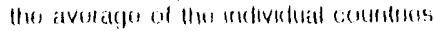

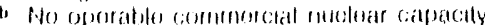

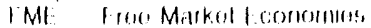

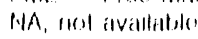

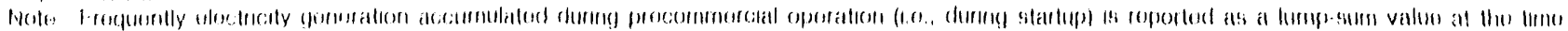

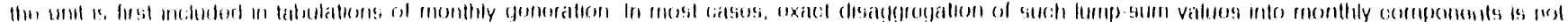

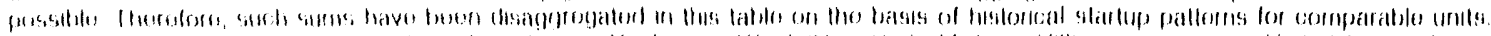

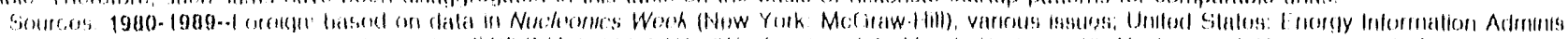

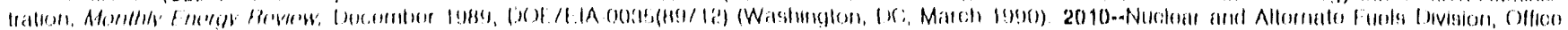

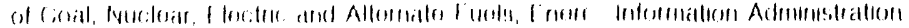




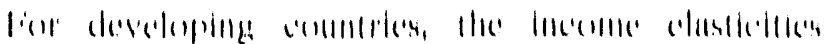

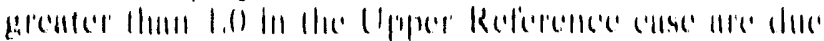

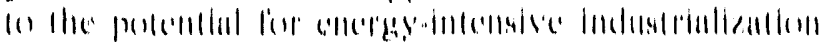

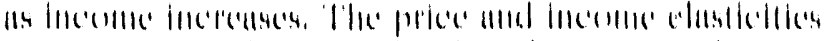

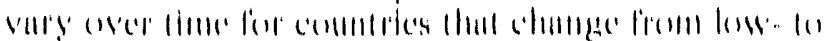

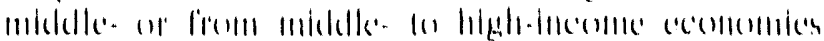

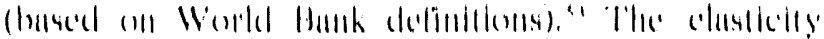

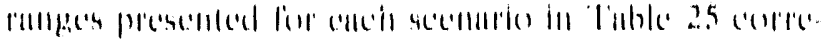

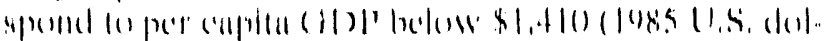

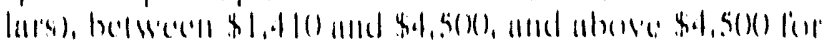

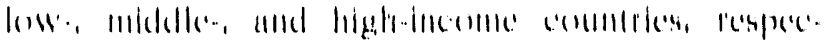

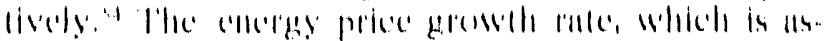

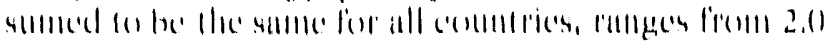

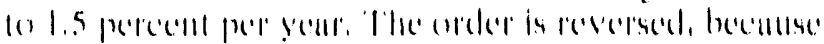

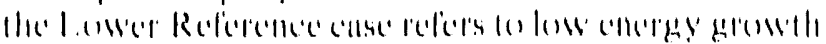

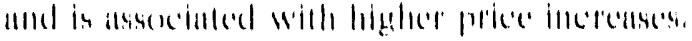

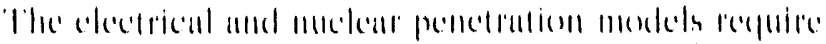

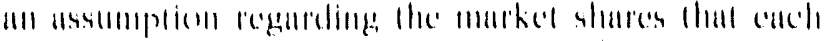

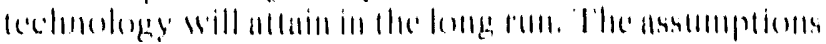

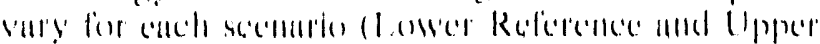

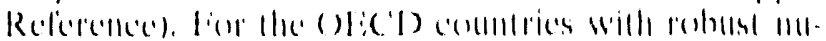

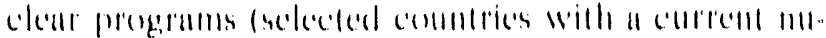

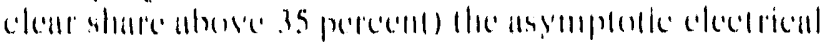

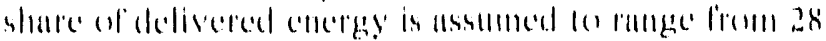

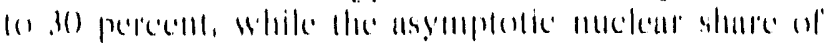

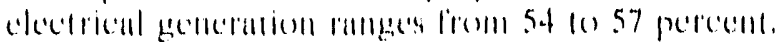

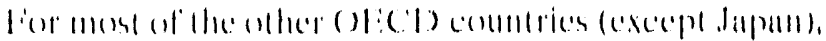

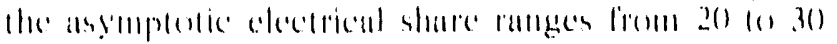

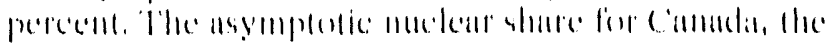

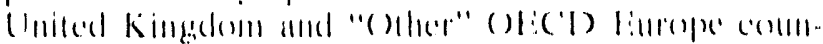

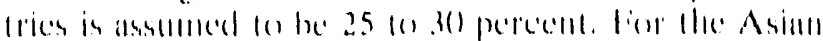

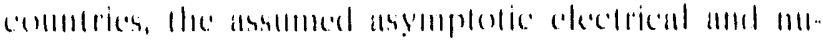

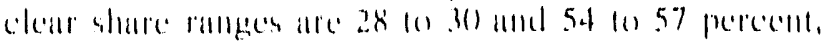

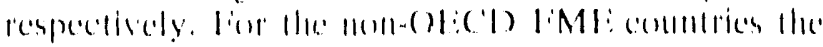

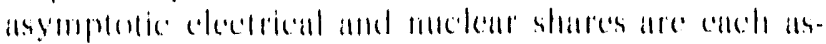

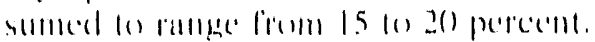

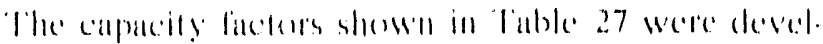

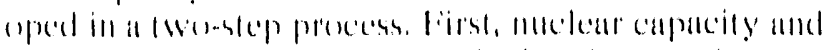

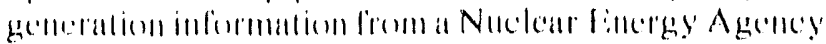
(NI:A) survery" was used lo develop conpucity fincluts hy eountery for dhe WINIS base year (i.c., the limal

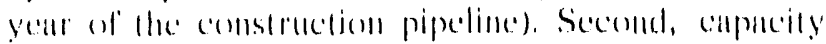
finclers lon 2010 were hased on historical values

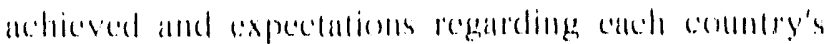

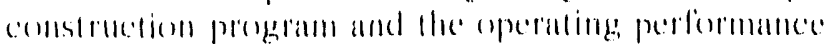

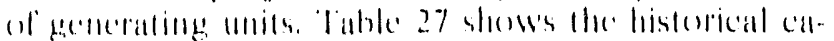

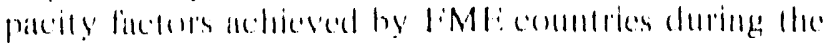

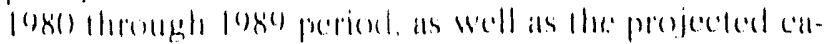

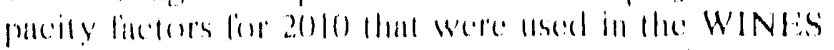

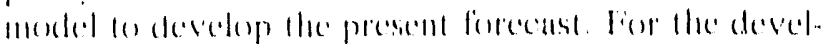

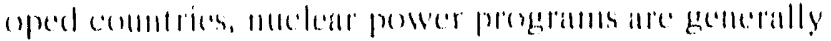

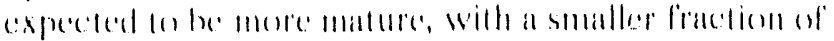

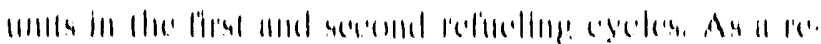

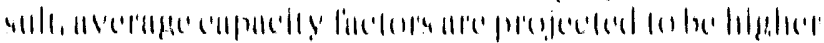

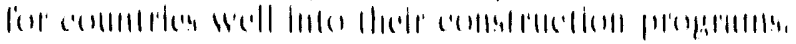

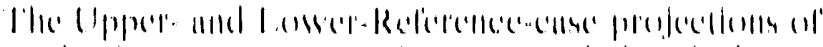

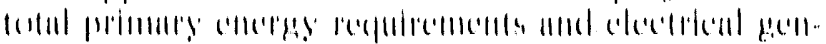

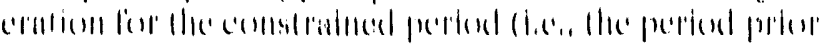

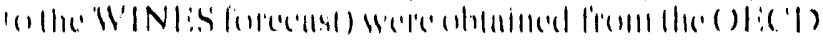

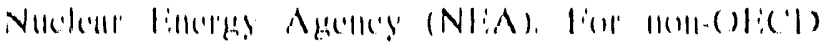

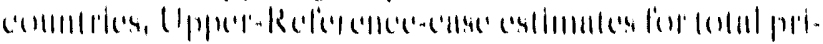

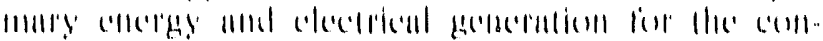

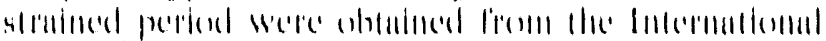

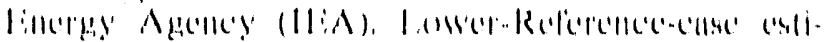

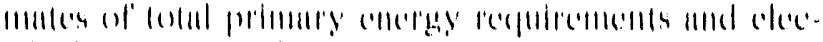

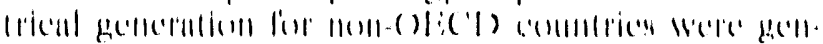

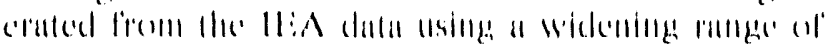

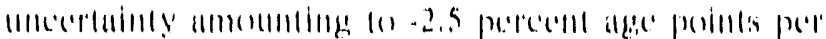

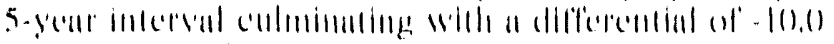

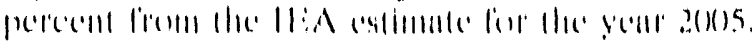

\section{WINES Model Projections}

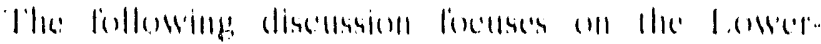

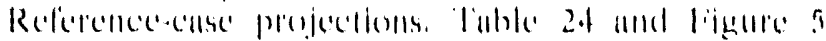
showe (1)

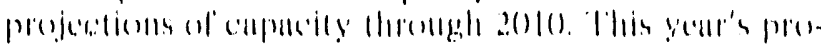

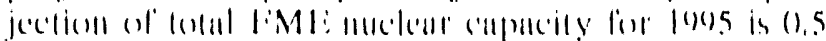

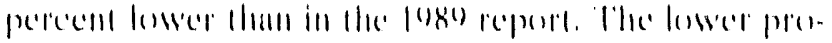

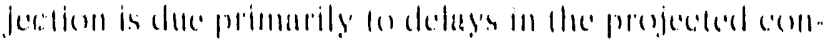

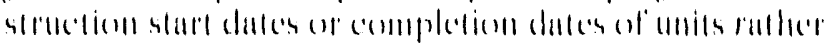

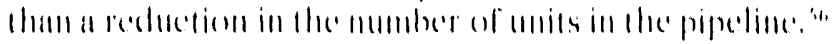

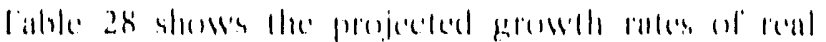

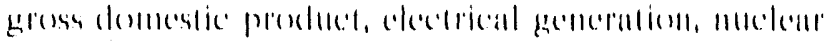

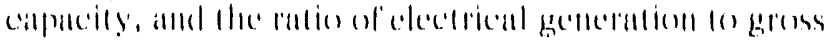

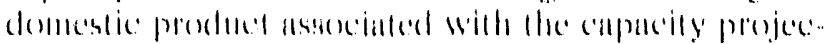

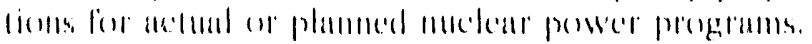

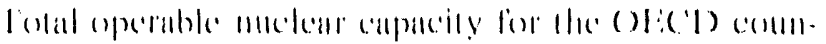

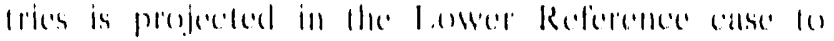

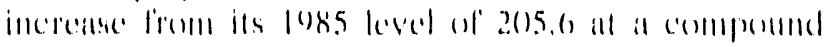

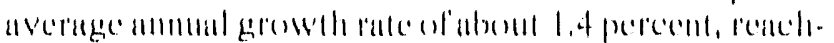

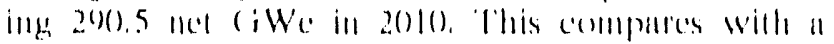

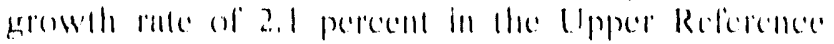

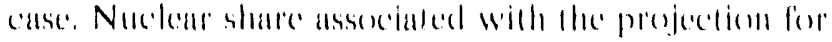

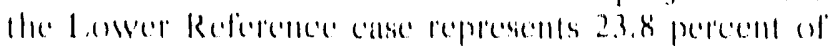

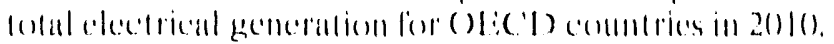

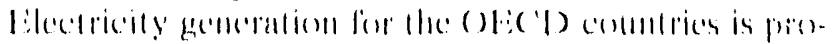
jected fo increase all a ralle al l. this periond.

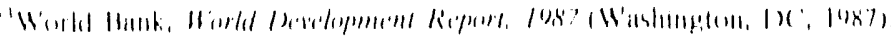

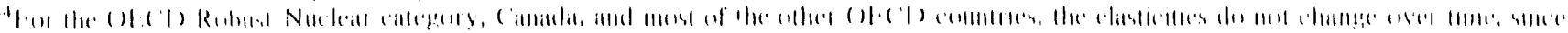

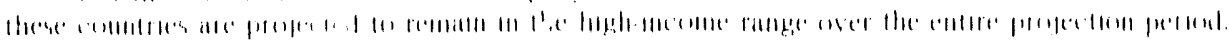

(1)

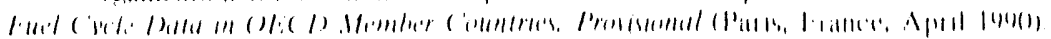

"thill
} 
Figure 5. FME Oporable Nuclear Capaclty at the End of the Year, 1989, and Prolections for 1990 Through 2010

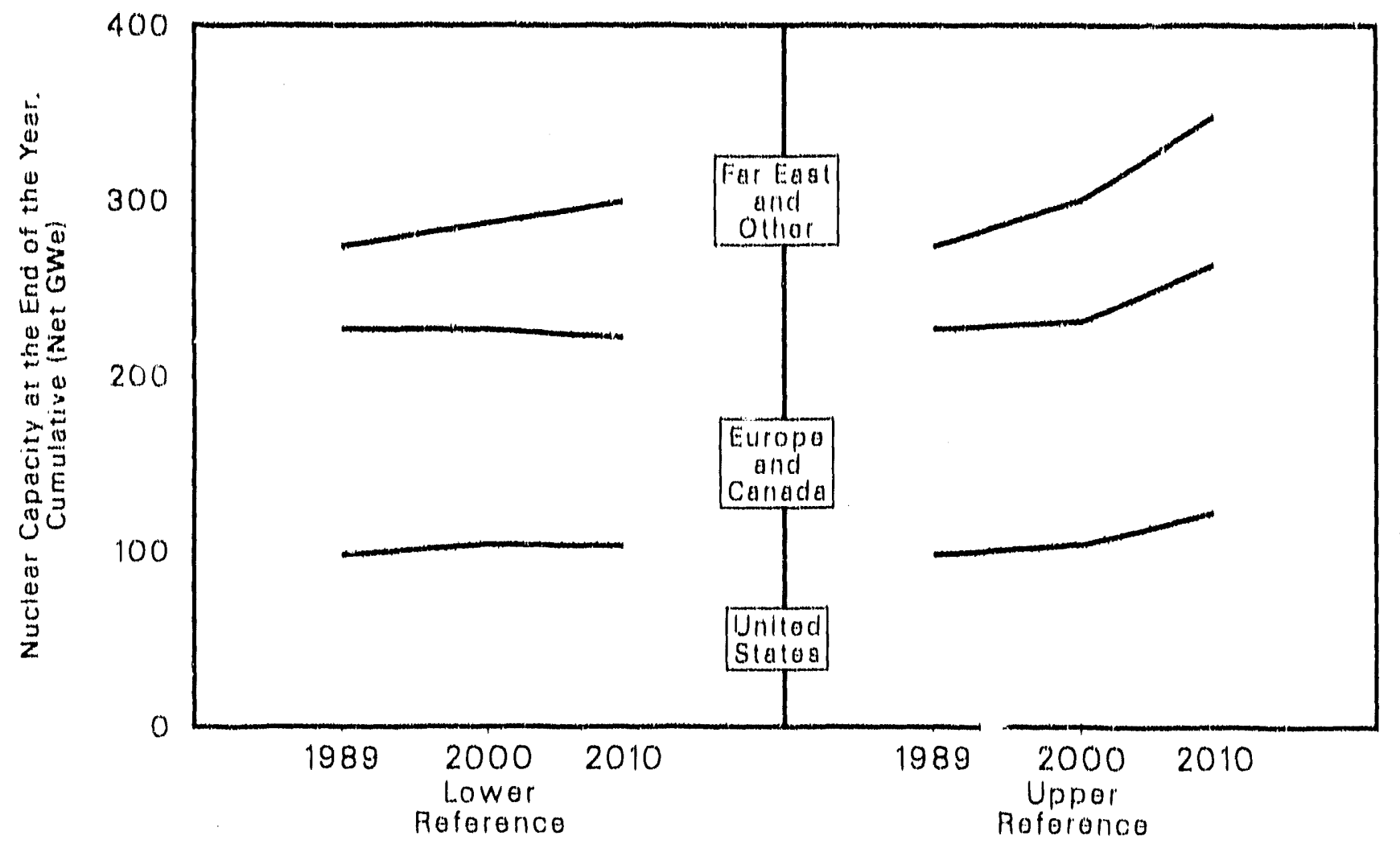

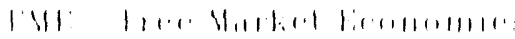

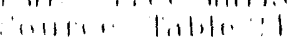

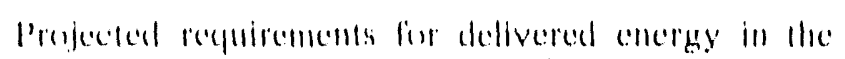

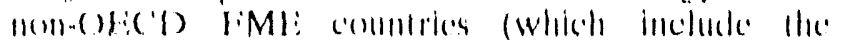

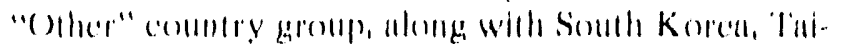

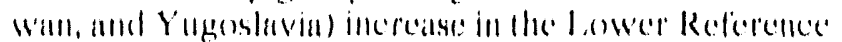

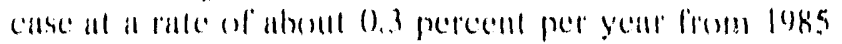
through 20) (0). The colectricul share of this recpuirement increases firom 18.2 percent 102.3 .8 perecent cluring lhe:

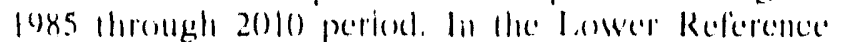

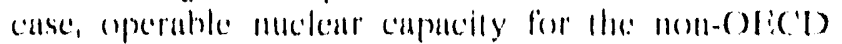

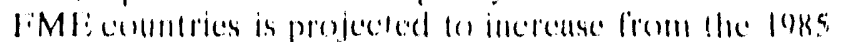
level of 13.0 (iW a al an avernge rale of 2.2 pereent per yent, rencting 28.1 (iWe in 20)10.

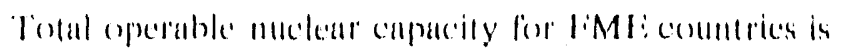
projected in the lowwer Reference cuse to increase from 27.3.6 110 (iWe in 1989 10 319 net (iWe in 20)10.

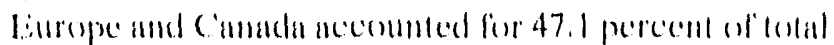

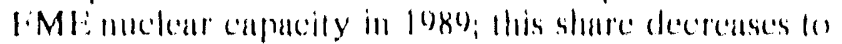
4.3 .4 perecent by 2010 (1) (igure 5 and Tuble 20). A simbilat

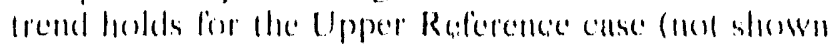

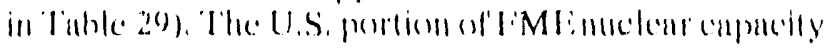

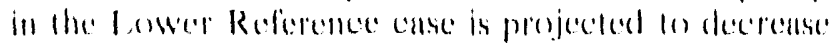
from the lege level at 35.8 perecent 10.32 .3 perecent in 2(1)10.

\section{Comparison With Projections From Previous Years}

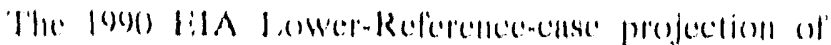

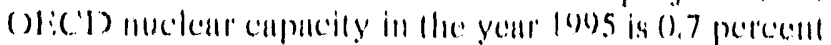

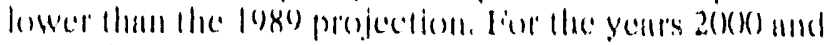

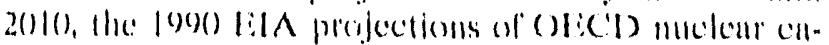

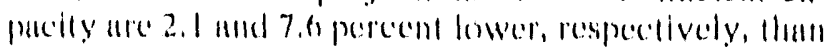
lice gese projections.

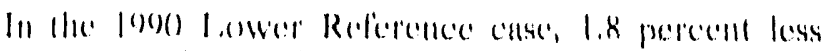
limli capacily (including U,s. caprecily) is projected

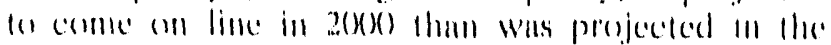
lanver Reforence case in loge. The slighil decline con

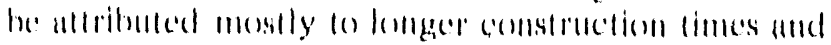

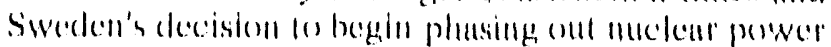

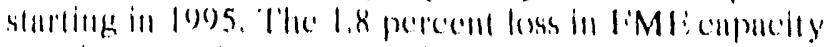

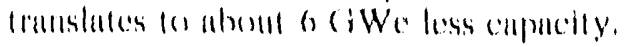




\section{Table 28. EIA/WINES Model, Lower-Reference-Case, Economic ariot Energy Growth Rates, for FME Countries, $1986-2010$}

\begin{tabular}{|c|c|c|c|c|}
\hline \multirow[b]{2}{*}{ Oountily } & \multicolumn{3}{|c|}{ arowlli halos (manil poroonl par yoar) } & \multirow{2}{*}{$\begin{array}{l}\text { Hallo of } \\
\text { Elactrlanl } \\
\text { Gonarallon } \\
\text { to Gop } \\
\text { arowth Pato }\end{array}$} \\
\hline & 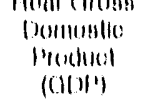 & 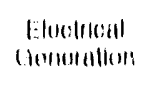 & $\begin{array}{l}\text { Ninolutir } \\
\text { Cinptabily }\end{array}$ & \\
\hline 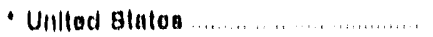 & $\|_{i}^{\prime} 11$ & $a^{\prime}(0)$ & 1.8 & 010 \\
\hline 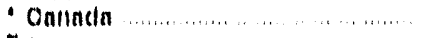 & $\therefore .1$ & 1,11 & $\because 1$ & .1 \\
\hline \multicolumn{5}{|l|}{ Europn } \\
\hline 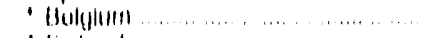 & 17 & $\therefore a$ & 0 & 1.1 \\
\hline 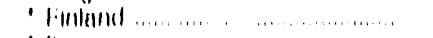 & 1.11 & 311 & 1.4 & 1.1 \\
\hline 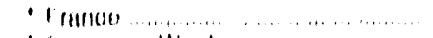 & i! 1 & $\therefore(1)$ & $\therefore 0$ & !) \\
\hline 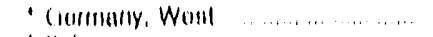 & 1.1 & l & 1.4 & 1 \\
\hline 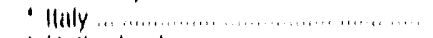 & 1.1 & 3.19 & $\therefore !$ & $\because 4$ \\
\hline 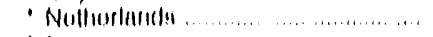 & $\therefore 0$ & 20 & 4 & 1.0 \\
\hline 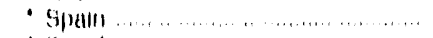 & $\therefore 1$ & $\because 11$ & $\because 4$ & 1.1 \\
\hline 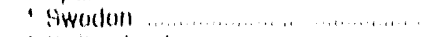 & 1.1 & i! & NA & .1 \\
\hline 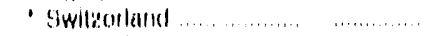 & 1.0 & 1.1 & .1 & 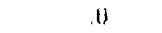 \\
\hline 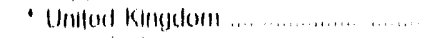 & 1.11 & $1, !$ & 1.1 & .11 \\
\hline 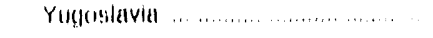 & $\therefore 8$ & $: 11$ & 1.0 & $\therefore .1$ \\
\hline \multicolumn{5}{|l|}{ Far Eant } \\
\hline$\ldots \ldots \ldots \ldots \ldots \ldots \ldots$ & 1 & 10 & $\because !$ & .11 \\
\hline 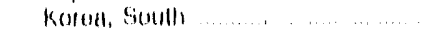 & 13 & $0 ! 9$ & (1.:' & 3.6 \\
\hline 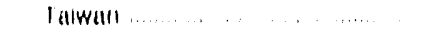 & 1.1 & 4.1 & 13 & 1.0 \\
\hline \multicolumn{5}{|l|}{ Othor } \\
\hline$\ldots, \ldots \ldots, \ldots \ldots$ & 1.11 & 19 & 20 & 1.1 \\
\hline |Hatil| $\ldots$ & 40 & 4.1 & B. 6 & $1.6^{\prime}$ \\
\hline 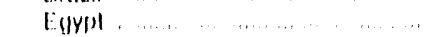 & 10 & $\therefore \because$ & NA & 1 \\
\hline India & 1.1 & 70 & $\because 11$ & 3.4 \\
\hline Muxiou $\ldots \ldots \ldots$ & 10 & ati & NA & 10 \\
\hline 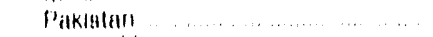 & 1.9 & 9.4 & 9 & 11 \\
\hline 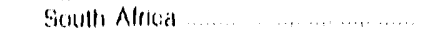 & 4.4 & 16 & 0 & 1 \\
\hline OECD Avarago & 10 & 1.8 & 1.4 & 1.0 \\
\hline Non-OECD Avoraga $\ldots \ldots \ldots$ & 3.8 & 1. 1 & ?:! & 19 \\
\hline
\end{tabular}

"Valuo shown is Ciross Nalional Producal (oinl')

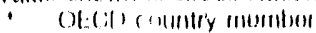

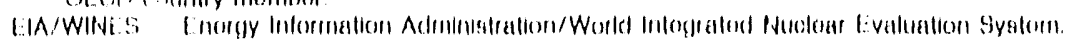

FME fron Markal foomomions

NA INol Apmliontola.

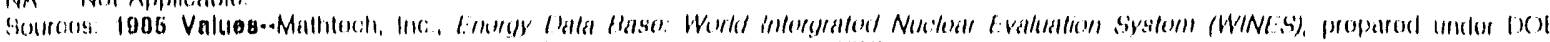

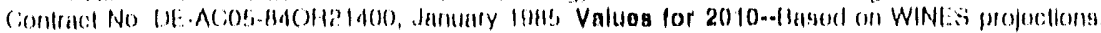


Table 29. Operable Nuclear Capacitles, 1988-1989, and Lower-Reference-Case Projections for FME Country Groups, 1995-2010

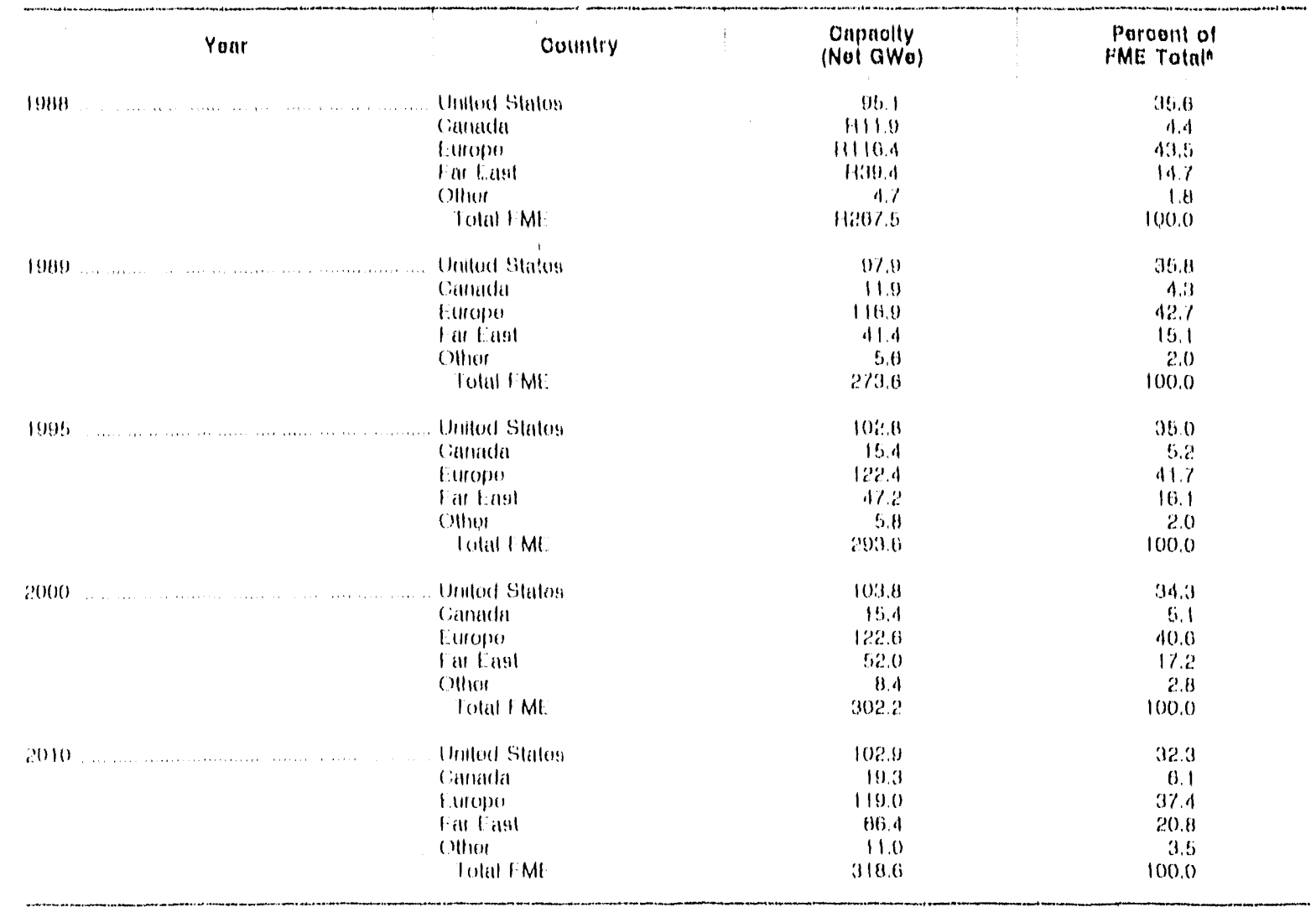

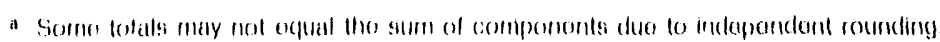
IME Proe Markel fonomiles.

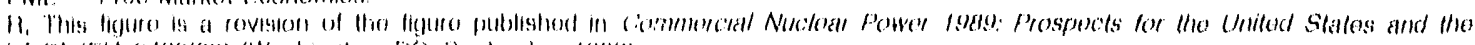

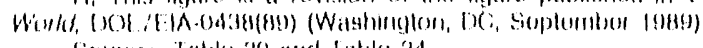

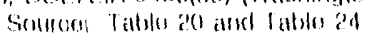




\section{Comparison With Other Projections}

Table 30 compares ElA nuclear capacity projections with projections from other organizations. for the OECD FMEcountries. The 1990 EIA projections are lower than the most recent projections of Nuclear Assurance Corporation (NAC), Nuclear Engineering International (NEI) and NUKEM.
For OECD countries in the year 1995, the 1990 EIA Lower-Reference-case and Upper-Reference-case projections of 275 and 282 net $\mathrm{GWe}$, respectively, are lower than the NAC, NEI and NUKEM projections of 306,301 and $282 \mathrm{GWe}$, respectively. For non-OECD countries in the year 1995, the EIA LowerReference-case and Upper-Reference-case projections of 19 and 21 GWe, respectively, are lower than the NAC, NEl and NUKEM projections of 24,25 and 22 GWe, respectively.

\section{Table 30. Comparison of Projections of FME Nuclear Capacity}

at the End of the Year, 1995, 2000, and 2010

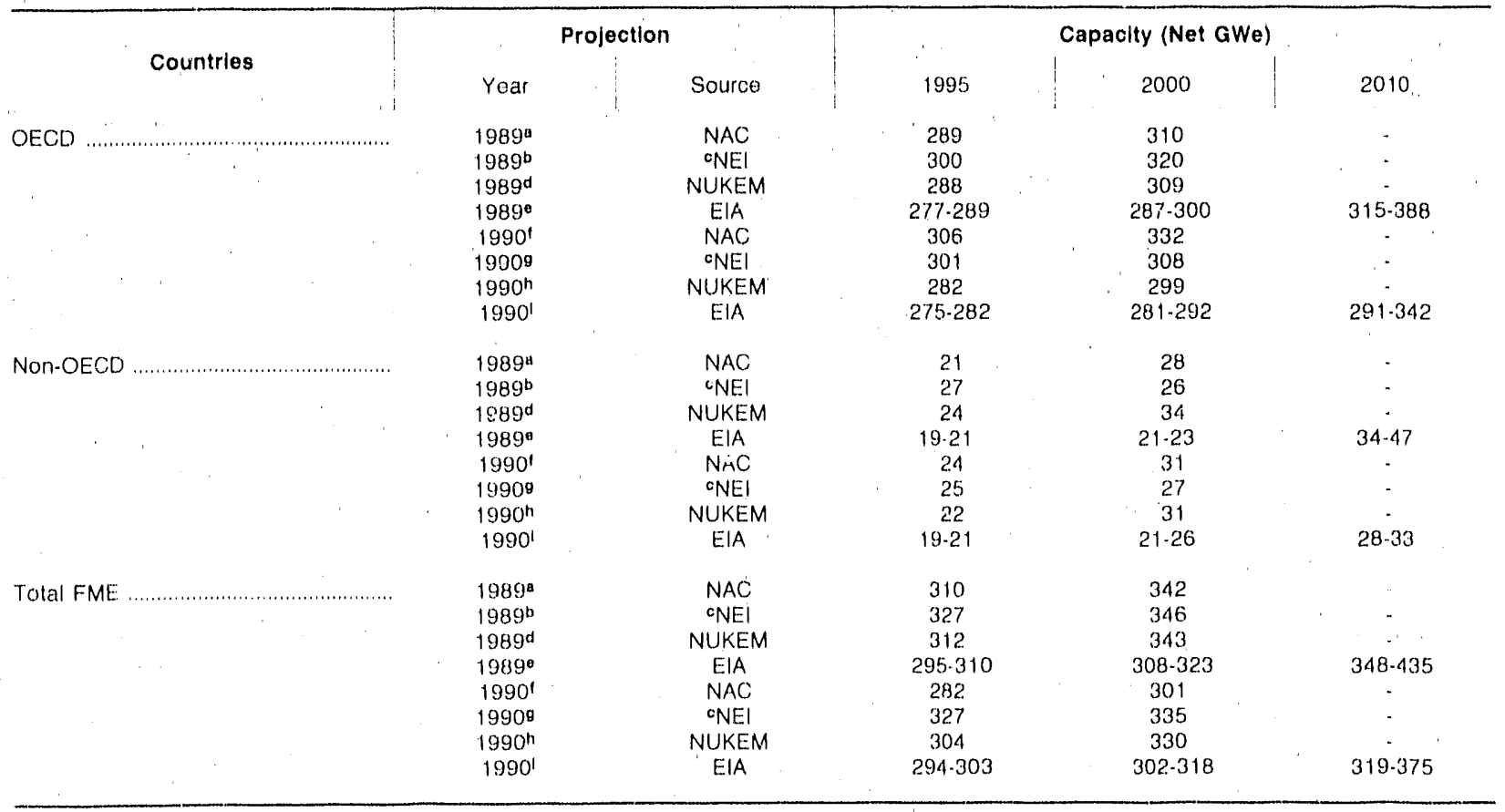

- Nuclear Assurance Corporation (NAC), Nucleair Megawalt Generation Status Report, Fobruary 1989.

- 1989 Nuclear Engineering International. "World Nuclear Industry Handbook 1989."

c Nuclear Engineering International projections are based on gross capacity data.

a NUKEM Market Report on the Nuclear Fuel Cycle (April 1989).

- Energy Information Administration, Commercial Nuclear Power 1989. (CNP): Prospects for the United States and the World, DOE/EIA. 0438(89) (Wastington, DC, September 1989). 1989 projections shown are, respectively, the Lower Reference and Upper Reference cases for 2000 and 2010. The 1995 Lower Reference and Upper Reterence case projections shown are part of the same projection series but were not published in CNP 1989

- Nuclear Assurance Corporation (NAC), Nuclear Megawalt Generation Status Report, Fobruary 1990

g 1990 Nuclear Engineering International, "World Nuclear Industry Handbook 1990."

$n$ NUKEM, Market Report on the Nuclear Fuel Cycle (April 1990).

1 1990 EiA: Consistent with this report, Table 24. 1990 ElA Projections shown are, respectively, the Lower Reference and Upper Reference cases.

OECD Organization for Economic Cooperation and Development

FME Free Market Economies. 


\section{Review of Foreign Nuclear Power Programs}

\section{Introduction}

This chapter concentrates chiefly on a review of nuclear power programs in foreign countries with nuclear power plants that are either operational, under construction, or planned. This chapter is organized into three major sect:ons: (1) countries with free market economies; (2) countries with regulated market economies (formerly countries with centrally planned economies); and (3) countries with centrally planned economies.

Chapter 4 includes an explanation of the thethodology used in projecting operable nuclear capacity for countries with active, potential, or, inactive nuclear programs. Table 2.8 on page 48 lists the projected econotnic and energy growth rates for each country for which nuclear capacity is projected. Nuclear capacity is not projected for countries with regulated market or centrally plunned economies. Table 20 on page 38 lists the current nuclear share for countries with free market economies.

Projected nuclear share is documented in the archived WINES model, which is available from the National Energy Information Center. Excerpts from these projections are highlighted at the end of each country writeup.

Information in this chapter was derived from diverse sources, ${ }^{57}$ some of which cited project completion estimates obtained through unofficial channels. In contrast, the material in Appendix $G$ was developed from two principal sources using a consistent set of definitions and project information based on official utility estimates. The country-specific discussions in this chapter focus on the Lower Reference case projections.

\section{Countries With Free Market Economies}

\section{OECD Countries}

\section{Belgium}

Belgian nuclear generating capacity reached $5.5 \mathrm{GWe}$ with the 1985 completion of Doel 4 and Tihange 3, the last two units in its nuclear construction pipeline. The seven nuclear units, all pressurized-water reactors (PWR), achieved an average capacity factor during 1989 of about 81 percent. The nuclear share of total electricity generation in 1989 fell to 60.7 percent from 66 percent in 1988.

Belgium officially canceled plans for the 1,390-MWe Doel 5 PWR in December 1988, and government officials proposed a cogenerating gas-steam plant for the equivalent capacity. Belgian authorities have issued a report stating that the country will need at least 3,500 MWe of new capacity before 2000 , with about 725 MWe expected from the 1,455-MWe Chooz reactors in France. The Chooz PWRs are to supply 25 percent of their power to Belgium starting in 1992. French vendors were to receive construction contracts for Doel 5 in reciprocation for the contracts that France gave the Belgian industry in constructing the Chooz. $\mathrm{B} 1$ and $\mathrm{B} 2$ units.

The Belgian government studied the country's nuclear industry in 1989 and was expected to issue recommendations calling for a single government regulatory agency. Parliament would ultimately discuss the recommendations and decide, possibly in 1990, on the structure and control of such an agency. Currently both public and private bodies are involved in Belgian nuclear regulation: (1) two government ministries control nuclear safety and ambient radiation; (2) three private companies award commercial licenses for nuclear

\footnotetext{
${ }^{57}$ Primary sources of information in this chapter include various issues of Nuclear Einginecring International (Sury, United Kingdems: Business

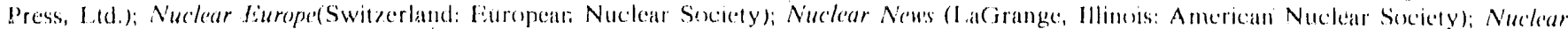

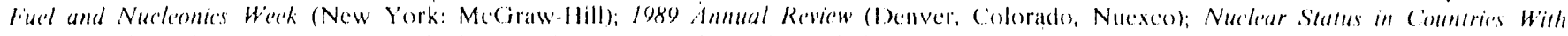

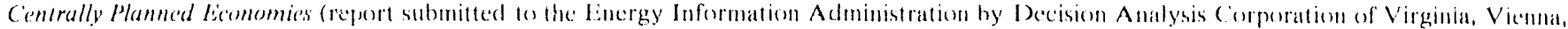
VA and Science Applications international Corporation. McLean, VA, June 29, log()). Most of the sources reflect information reperted through April 30, f9g), hut a few sources include information reported through May 19g().
} 
power plants and derive income from those plants; and (3) other mational and regional authorities approve the construction of nuclear plants. Depending on the outcome of the parliamentary debate on the matter, there might he onc public agency ultimately controlling all asperts of muclear secourity and safely, including commercial liecensing and condination of waste disposal. If such an agency were created, the three licensing companies would be dissolved. Other government officials propose letting the licensing companies survive but with tighter eontwol by the gevernment regulatory body.

Three private utilitics control es pereent of the Belgian electricity market and gencrate most of their power from mackar plants. The three utilities plan a merger in 1990 (0) prepare for a deregulated European Community (EC) energy market in the mid-1900's.

Projections for $20(0)$ assume no additiomal nuclear capacity. In the lower Reference case installed capacily will remain comstant at 5.5 (iWe by 2010. The nuclear share of Belgian electricily gencration in the lonver Reference case is projected to decrease from nearly 60.7 perecoll in 1989 to 38.5 percent in the yeat 2010. LiA projects electricily generation 10 grow at a yearly rate of 2.2 pereent from 1985 through 2010. These projections are based on an ecomomic growth rale of 1.7 percent per year.

\section{Canada}

Canadian nuclear policies and regulations are moder the jurisdiction of 1 wo different authorities. Alomic Energy of Canada, Lod. (AECL) is responsible for promoling and developing nuclear energy, and the Atomic Panergy Control Brard (AECB) is responsible for its regulation. The role of the ALC B is simbar to that of the U.S. Nuclear Regulatory Commission (NRC). The major defference is that Provincial govermments may directly participate in the regulatery prosess, and maty require safely assessments ans a contdition for the construction and continued eperation of nuckear plants. Such an assessment program Was Intdertaken in Ontario Province, where molear.

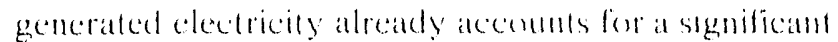

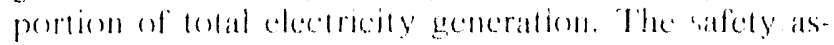

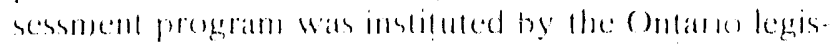

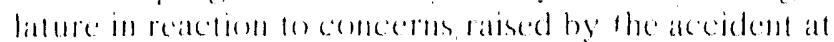
chemolnyl in April loses.

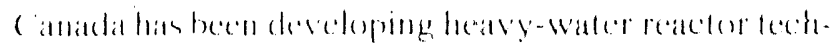
moleges since the end of Worlel War II. In contlase to other reactor types, the heavy-water reactor is fueled with natural (nomentiched) uranium. The development of the Canadian pressurized heavy-water-moderated and cooled reactor (PHWR), the Cantandian DeuteriumGranium (CANDU) reactor, began in 14)62 with the construction of the 22-MWe NPD demonstration unit, which was decommissioned in 1988. This wats followed in 1968 with the Douglas Point 220-MWe prototype CANDU reactor, now shut down. One advantage of the (ANDU reactor is improved operating performance due fo on-line refueling capability, and lower temperature and pressure parameters. All operating and planned Canadian reactors are CANDUs.

Canada has 18 units presently in operation with an installed nuclear capacity of 11.9 GWe. Work on the four Darlington units with 3.5 GWe of capacity continued during 1989. The Darlington 2 unit was shut down halfway through its precommercial testing process in rebruary 190) due to a cracked rotor that could take 2 years to replace if the crack resulted from a fault generic to rotors in the three other Darlington units. If the rotor can be replaced from Unit 4, which is the last unit scheduled for service, lesting could resume around May log().

In December 1989, Ontario Hydro (OH) subnitted its 25-year plan to the Ontario Minister of the Environment. The plan includes proposals for new hydroclectric facilities, natural gats-fired plants, nuclear power plants, conscrvation, efficiency improvements and power purchases from independent power producers and neighboring provinces to meet the electricity needs of Canada's most populous province. The largest portion of new electricity is expected to be nuclear gencralced.

The propesed schedule calls for the utility to begin work on the lirst of four ( A NDU-A reactors in 1995 ; the mints would eome on-line between 2003 and 2006 . An envirommental assessment for the first of four (ANDU-B reactors would be submited to the provincial govermmers in 1996; they would come on-line between 2()(e) and 2012. The first Iwo of four CANDU. C units would go on-line by 2()1.3, with the other 1 wo units to be completed after the 25-year period of the oH plan. (The (AND) $\triangle A, B$, and $C$ series replesent evolulionary design improvements in CANDU PHWR cechmology.) The oll proposalt states that the addilional muclear capacity musl arrive in large quantities so that Oll call meet its projected demand. The (oH fow-geowth soconato expects demand growth averaginge 1.5 peresent per year, with 2.2 percent per year

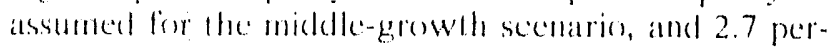
cent per year for the high-grewh scenario. The utility meles that hy 2014 appreximaledy $8,50(0) \mathrm{MWe}$ (1) capacily will have been sholl down becaluse of agilig.

The Canadian and Sovied gevernments have signed a comprefomsive nuclear conperation agrecment that could end 25 years of on again, off again lechnical dis-

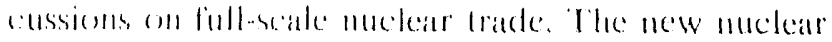


cooperation agreement will enable Canadian eompanies, notably OH and AECL, to respond to Sovice interest in acquiring Canadian nuclear safety equipment and technology.

In the Lower Reference case, Canadian nuclear capacity is projected of grow 1015.4 GWe by 2000 , and to reach 19.3 GWe in the year 2010 . The nuclear share of electricity generation is projected fo increase from 15.9 pereent in 1989 10 18.6 peroent in 2010. EIA projects electrical generation to grow at a rate of 1.8 percent per year from 1985 through 2010. These projections are based on an economic growth rate of 2.4 percent per year.

\section{Finland}

Under Finland's Nuclear Energy Act, which became effective in March 1988, a new Advisory Committee on Nuclear Energy was allached to the regulatory body, the Finnish Centre for Radiation and Nuclear Safety (STUK), that was established in 1984. The government sets down general safely regulation, while STUK prepares detailed regulatory guides. Finland has three stages to its procedure for licensing nuclear power plants: a decision in principle; a construction license; and an operaling license. The Parliament is involved in the first stage which includes siting, envin rommental aspects, and arrangements for nuclear fucl and waste management. The Government issues the two licenses.

Finland has four operable nuclear units with a tolal capacity of 2.3 GWe, but it has no nuclear fuel cycle industry. The Soviet Union supplied the two reactors for the Loviisa nuclear power plant that is operated by the Finnish state utility Imalran Voima Oy (IVO); it also provides the reactors' fuel assemblies under long-term contracts and agreements. Sweden supplied the feactors for the Olkiluoto nuclear plant that is operated by the private ulility Teollisumden Voima Oy (TVO), which currently obtains uranium, enrichment services and fuel assemblies from suppliers in Austratia, Canada, China, West Germany and the USSR.

A 1989 report by the Fimmish power industry projected increasing electricity comsumption in the log)'s 10 exceed supply by 1994. Demand for power was estimaled to increase at ant anmual rate of $: 103$ percent thengh 1998. To build more conventional power plants would conflict with the country's commitments to reduce air pollution. Finnish companies are contracting to import sizable amounts of natural gas and electricity from Norway and the USSR.
Although the current government promised in 1986 to suspend any decision on the fifth nuclear unit during its term of office, it now appears that planning for such a reactor may begin after the logl elections. Expansions of coal-and peat-lited plants would conflice with parly support of a cleaner environment that advocaled reducing by 1993 the sulfur and carbon dioxide emissions to half of their corrent levels. It is coubtful that Finland eould expand its hydroelectric power capacity because of the country's law on preserving natural waterways. Also, Sweden or the USSR may not have surplus electricity available for export in the late log()'s or after $2(0)(0)$ Finnish industry hopes that a decision to construet the fifth nuclear unit will be macke before 1992. A eompany, Perusvoima, has been set up to plan and build such a reactor and has informed the government that it must decide by 1992 to build the plant that could be generating electricity by 1998. A Perusvoima official has stated that, if Finland purchased a nuclear plant now, it would buy this plant from ABB Atom, now part of Asea Brown Boveri, whose safety standards and lechnical requirements are in line with those in Finland.

In the Lower Reference case, Finland's nuclear capacity is projected fo remain constant at 2.3 GWe through 2000 and reach 3.1 GWe in 2010. The nuclear share of electricity generation is expected 10 decrease from its 1989 level of 35.4 pereent to 27.3 pereent by 2010 . Electrical generation is projected to grow al a rate of 2.1 pereent per year from 1985 through 2010. These projections are based on a yearly economic growth rate of 1.9 pereent.

IVO International Lfd. and Atomenergoexport plan to conperate on optimizing the economics and verifying the sifety of Soviet VVER-10)(0) PWRs. The USSR has offered to supply its VVER-10(0) to Finland which would be able to assist in the development of the reactor. A Fimmish safely expert believes that the current design does not meet the advanced requirements of the regulatory agency SIUK. Specialists at IVO Intermational think that by 1992 the VVER-10)() will be competitive with reactors offered by ABB Atom and Nuclear Power International, the Siemens/KWU and Framatome partnership, which are the other alternalives for a fifth Fimmish nuclear unit.

\section{France}

The firench naclear power prograni began in 1956 with the operation of a $2-M W e$ experimental reactor, and in the late logots PWR technolegy became the 
foundation of the French program. Framalome, lice French supplier, has developed and mantaluctured a standard-design PWR based on a Westinghouse Corp. license, thereby creating substantiul savings in the costs of engineering and production. This standardization has helped the mational atility. Electricite de France (EdF), to huild its muclear reactors in an average cotrstruction time of less than o years.

In December 1989, the Nutional Assembly debated various aspects of French energy policy. The Assembly apparently will become more involved in developing the nations's encrgy policies, especially the back end at the fuel cycle and the breeder option. One teple debated was a proposed 1986 bill to ereate a nuclear safety organization that would be independent of the federal government and might have veto power over construction permits or operating licenses for nuclear facilitics.

France has 55 operable nuclear units with a capacity of 52.6 GWe. No units went into service during 1989 , but three PWRs were connected to the grid in February 1900-the 1,30()-MWe Cattenom 3, the 1,310-MWe Golfech 1 and the 1,330-MWe Penley 1. Another six units with 8.3 GWe of capacity remain in the construction pipeline. Although these six units create a temporary period of overcapacity for EdF, the utility expects that future increases in domestic business demand and exports will eliminate any excess reserve capacity by 1992 or 199. 3. EdF plans to shut down its Saint Laurent Al GCR (gas cooled reactor) in: 1990). The remaining GCRs (Saint Laurent A2, Chinon A3 and Bugey 1) are scheduled for closing belween 1990) and 1994, with the Saint Laturent A2 to be decommissioned after work is completed on the first unit. These reactors will not be dismantled until several decades after their decommissioning.

Edf's nuclear gencralion rose 5 pereent in 1989 to 28.5 billion $\mathrm{kWh}$, which wats 75 percent of the utility's total power generation. It exported 42 billion $\mathrm{kWh}, 12$ percent of its 1989 production, and signed firm contracts to expont an additional o or 7 billion $\mathrm{kWh}$ annually starting in 200(). EdF might attain yearly exports of 50 billion kWh to neighboring countrics in 1991 or 1992 , and its Chairman indicated that his ultimate goal was (o) export 8() billion $k$ Wh per year if the European transmission network can be improved sufficiently.

The utility's $9(x)-M W($ PWR s averaged an 81 -percent availability, while the $1,3(0)-\mathrm{MWe}$ reactors averaged only a 62-pereent availability. Since EdT, unlike most other comntries, uses its nuclear power plants for loadfollowing as well as for baseload generation, the availability factor is a more appropriate measure than average capacity factor, especially when comparing the performance levels of lirench plants to those noted loy other commlries in this report.

Ealf plans to repatir its 1,3(1)-MWe reactors in the next 2 years by inspecting the steam generator lubes on both operating units and those under construction, plugging problem tubes, and performing chemical cleaning. There will be lower avallability firom these renctors during the repair outages, and the lost nuclear generation will be replaced by power frem morecestly fiucls.

Nuclear capacity in france is projected in the Lower Reference case lo incerease from 52.6 GWe in 19891062.3 GWe in 2010. Nuclear capacity is expected to grow at a rate of 2.0 percent per your. ElA projects the nilclear share of electricity 10 decrease slightly from 74.6 percent in 1989 to 70.5 pereent in 2010. Electrical generation is projected to grow at a rate of 2.0 pereent per year from 1985 through 2010. These profections are based on an economic growth rate of 2.1 per. cent per year.

In August 1989, government officials issued a permit allowing the Superphenix fast breeder (Creys-Malville) to operate for 405 full-power equivalent days or until the current fuel load is exhausted. The Superphenix had been recomnected to the grid in April 1989 but was again laken out of service in the fall of 1989 after a bubble of argon gas was detected in the core of the 25()-MW protolype Phenix last breeder, Subsequent tests disclosed that, strould a similar bubble develop in the Superphenix reactor, it would not canse any sig. nificant problems. The large FBR relurned to selvice in Spring 1900.

The Hungarian Electricity Board (MVMT) and LedF have agreed 10 prepare a joint study during $1900 \mathrm{om}$ the possibility of EdF supplying two g()()-MWE PWRs for the Paks nuclear power station. EdF would provide 70) percent of the construction costs and be repaid by transmission to western Europe of power generated by these units. New transmission lines would need to be constructed, possibly in Alsitria, with sales of power beginning in 1997 or 1998. The French would supply the uranium, take back the spent finel, and provide operating assistance to the Hungarians for up to 5 years.

EdF and a French instilute signed agreements in 1989 and 190() with Sovict organizations for cooperation in various nuclear fields. Possible areas of conperation might be the sufely of eperating nuclear power plants; accident recovery based on actions laken after the Chernobyl accident; the design, construction, and decommissioning of nuclear facilitics; and enrichment af reprocessed uranium. 


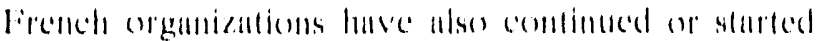

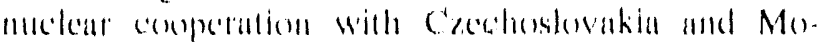

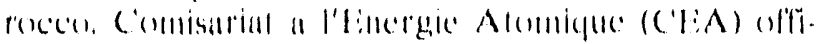

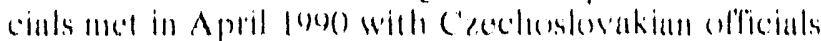

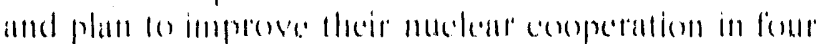

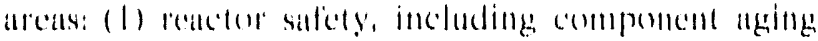

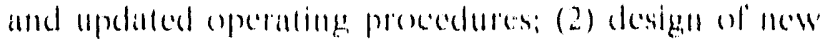

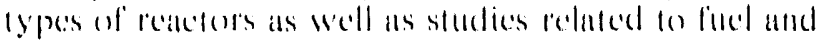

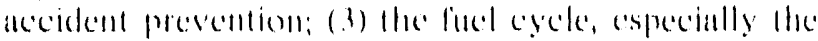

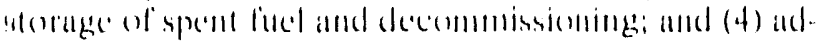

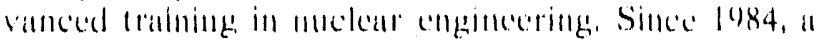

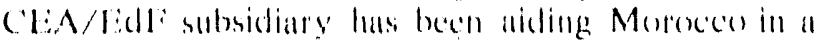

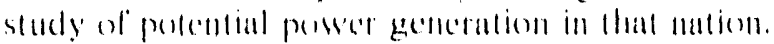

\section{Germany, West}

As of December 31, foge West Cicmanty had 22 (1)-

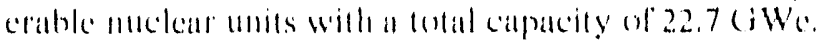

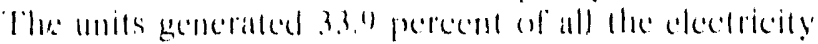

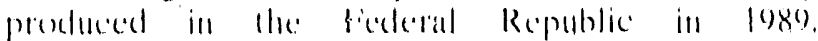
Neckarwestheim 2, a 1,3()().MW' PWK designed and

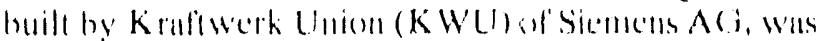

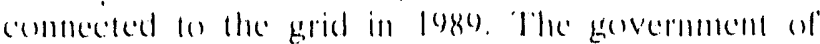
North Rhine. Westphalia (NRW), the federal gevermment, and the operating company Hecehtemperalur

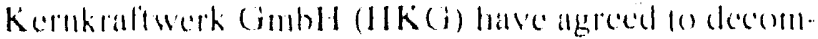

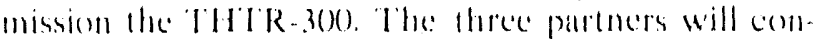
tribute jointly lo finance: decommissioning without

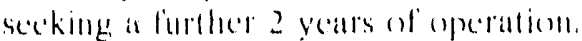

Nuclcar capracity in West cicrmany is profected in the lower Reference case to incruase from its 1989 lotal of 22.7 (iWe to 23.0 (iWe in lo9s. Capacily in 2010 will remain constant at 230 (iWe. EIA prejects the nuclear share of electicity genceralion lo decrease slighlly from ils 1989 level of 33.9 percent 1028.8 pereent by 2010 . Elecerical gentcration is profeceled lo grow at a rate of 0.9 percent per year linem loses through 2010 . These progections arce hased on an ecomomic growth rate of 1.3 percent per year.

The country has only onse muclear unit, the SNR-3()() FBR in Kalkar, remaming in ils muclear comstruction

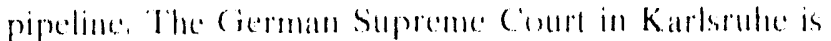
expected to rule in July 1000 on the comstitutionality of a lederal ordere to step up licensing af the mait. The

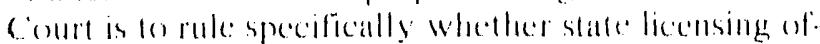
ficials may comtinue to study the saliety of the SNR - 30) before issumg an operating license. The pending Court verdict will be significant, becallese it is expected 10 draw the benndary belween federal and stalc powers in licensing of all nuclear factilices in West cormany.

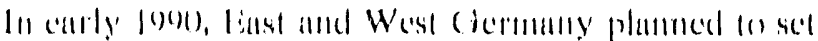

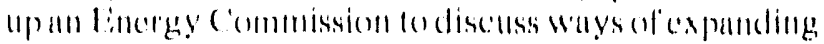

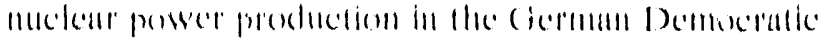
Republic (Ci) R), The Commissiom of experts from

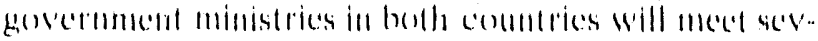

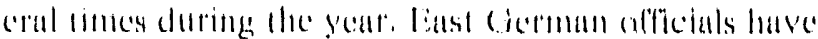

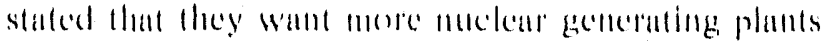
lo replace antigualed lighile fïred plants. Al present

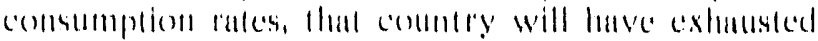

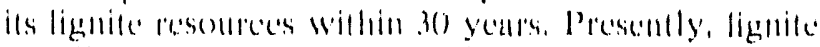
supplices uhout 85 perecent of the comontry's chectricity production, Also, aplan lo complede a 380-k V lransmission line from West (icimanty throngh Berlin and

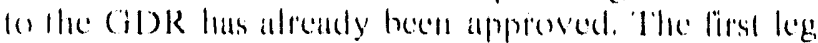

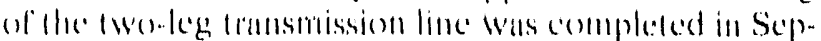

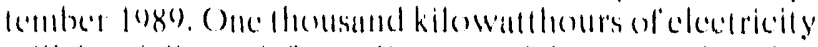
will be delivered from Preussemelektra $\wedge$ C in West Cicrmatly lu lle (il)R.

\section{Italy}

The Ilatian centumercial nuclear power progeram began in the 1050's with the ofedering of three nuclear units by the stalce electric utility, linte Nuziomale per

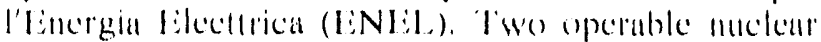
Imils remainced as of December 31, 1989, with a lotal capacity of 1.1 ( 3 W 6 . There additional units, foraling 2.() (iWe, are enrently under construction.

The Ilalian govermment had approved an ambitions muclear construction program that called for an addiliomal 10 oWe of anclear capacity before the year

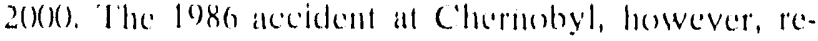
newed anti-nuclear sentiment and a feferendum on the gevermment's nuclear power policy was called by popular petition and held in November 1987; this resulted in a 5-year suspension of the planned expansion.

The government later proposed a nonnuclear policy in its 1988 through 1092 energy plan. This policy calls fore the mothballing of the Caorse plant, and the decommissioning of the Trino Latina and Garigliano plants, with the nuclear sections entombed for 30 years and the remander of the units eomverted fo gats-fired units. ('Trino I and Cansos are still on standby loaded with fuel. 1:Nbi, has staled that Trino I is ready to restart on (lemand, whereas some backfits anc necessary lo restart he (a)rso reactor.) The 7()-pereent complete lwo-unt Montalto di castro plant will be converted to an oil-., gats-, or, conl-fired plant with four 64)-MWe

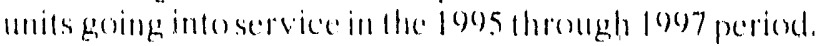

Due on the shumdown of all its moclear plants and prolomger alelatys in comslruction of comventional power

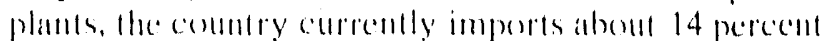
of its electricity from frames, Switzerland, and West

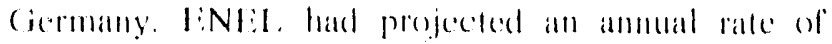

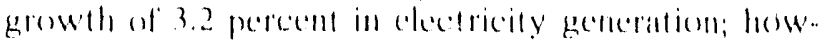
ever, demamel hats beent rumnings wedl over + pereent fir the past liew years. 


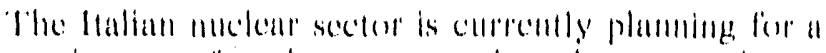

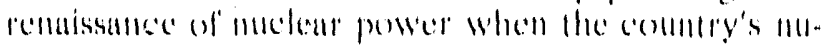

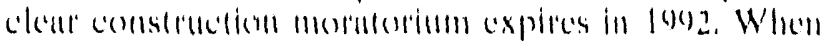

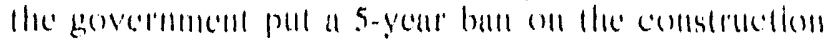

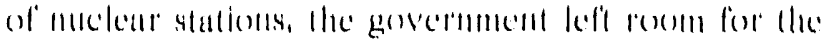

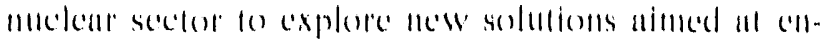

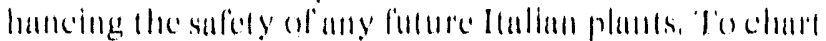

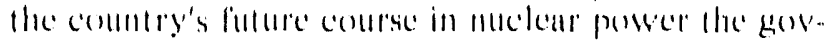

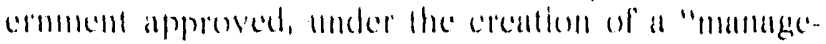
ment commintes," the corrent National Energy Plan.

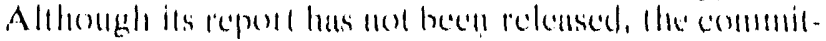

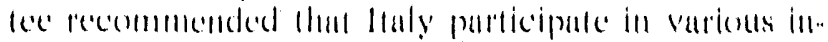

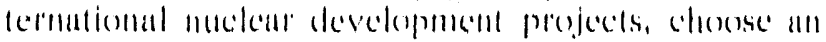
appropriate reactor type, carry out a detailed design, and constried a plant al an appropriale time.

ENEI is active in the working geremps of intermational orgunizations invelved in nuclear safery, including the Workd Asscrefition of Nuckear Operators and its work om advanced renctur concepts, such als gas- and sodiumconked reacters. The mility has contacted major ven-

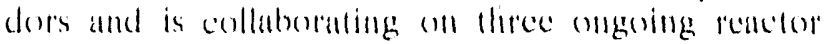
projects, two sponsonded jointly by the U.S. Depurt. ment of Energy and the likectric Pewer Resenteh ln. stifute, and one wills Asea Brown Boveri (ABB). In

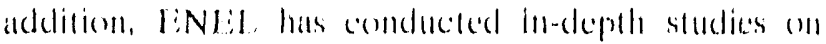

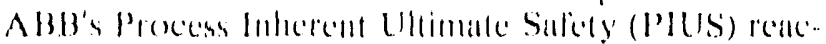
(1)!.

The LiA exprects lanly's installed muckear calpalcity in the lonerer Refierence calse lo lotal

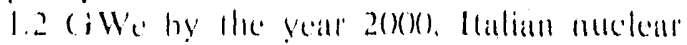
capresty is profected to reach 3.1 GWe in the year 2010. The nuclear share of elecetricity

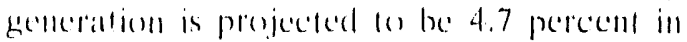
2010. Blecericity generation is projected to grow all a rate of 3.3 percent per yeatr during that periond. These projections are based on and centomic groweth rate of 1.7 perecent pere ycirt.

\section{Japan}

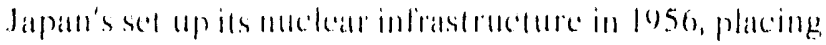

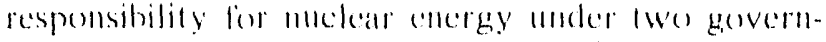

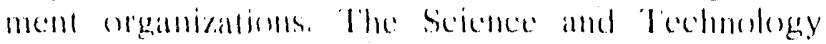
Agency (STA) is responsthle for all rescatreh and le. velopment activities, and the Ministry of latermational Trade and Indusily (MI'l'I) is responsible for commerer. cial and industrial alctivitics. The Alomice lancrgy ('om. mission (Afre and lite Nuclear Saldely Commission (NSC) ai Hhe Prime Minister's (office previde overall complimation of murelear activities. The NSc establishes

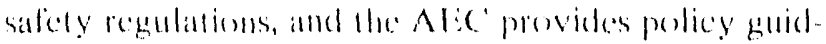
ance for melear conergy development. Ome of the main

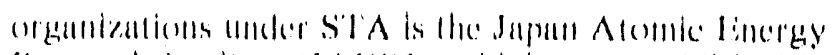

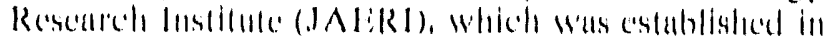

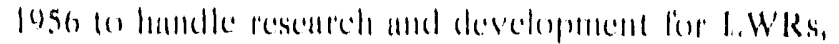

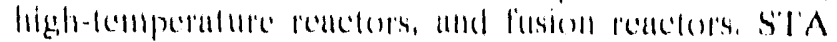

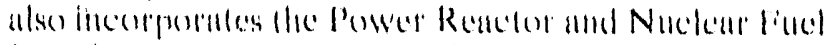

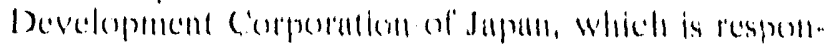

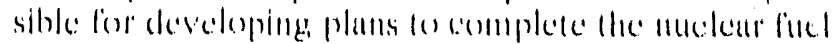
eycele and combinming rescurch an bereder renceders.

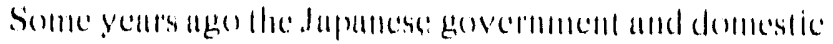

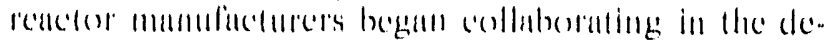

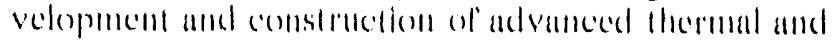

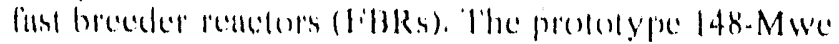

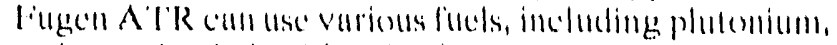
and was londed wille mixed oxide find in log8. The

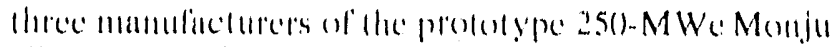

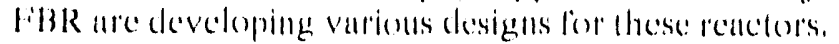
The Monju libR is uboul 75 perecent complete and is expeceded fo be (1) perable in l(5).3.

LiA projecels that Japants muclenr capacily in Ho lower Reference (anse will increase al an average ralle of aboul 2.9 pereent lirom las.

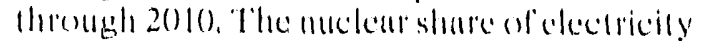
gencralion is projected lo incerease froms its joge level of 25.5 pereent 10.32 .3 perecent in 20)10, Elecericity generation is projeceled lo girow al 11 rille of 1.6 perecent firoml 1985 through 2(30). These projections are based on ans cecollomice growith rate of 2.1 pereent per yearl.

Kashiwazaki Kariwa 5 was conneceled to the grid in Sicplember loge and began commerecial operation in April 190(), bringing Japan's nuclear capacily 1029.3 (iWe. The comnty has 39 operable nucleal moits and ranks third anmong I:Mliconntrices in lerms of installed maclear capacily. Japan has 20 units with 25.8 ciWe of sapacity in the molear construction pipeline.

Japan's muclear generating units had an average capacity factor of "yo pereent for the year ending March 31. 190(), the lowest in 7 ycars. Ihe PWR had the highest average capacity lacelor of 7.5 perecent, with the Tomari I moit operaling at $1(x)$ perecent capracily, I argely becanst of fuknshima Daini 3 being off-line virtually all (af lo89, the BWRs operated all an average capateity liactere of 67 percent dering the same periond.

The Al:c silated in a late loge papres thal Japan's hest encergy mix calls for mocelear power generation lo play

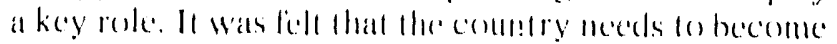
less dependent on pedenderum than in the past, particu-

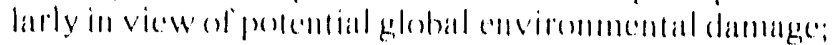
its rapidly increasing demand for encergy; and poser 
prospecets for renewable errergles stach as solar and wind.

The JAERI and Ho Uniled Kingdom's Alomic Luergy Authority signed a 3-year agreernent in March log) to

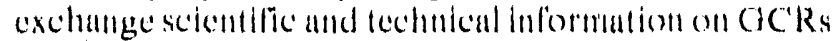
and PWRs. France and Japan have extended their all-

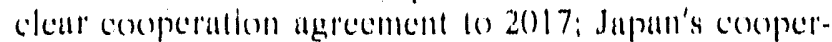
alive agrecoment with the United Slates also runs to 2017. Japan has ased largely lenench technology lo design its Rokkushomura commereiul reprocessing plant now under construclion.

\section{The Netherlands}

The Dulch nuclear power program hegun in the early 1960)s with the ordering of " $55-M W E$ BWR al Dodewand, which became operational in 1968. A see:and unil, the 445-MWe Borssele l'WR, began commer'cial operation 5 years later. After 2 years of public debate, the Duteh government in 1984 approved the construction of at least two more nuclear units, ench of $9(0)$ - $101,3()$ () - MWe capacity. The coulition government reached its decision after review of a report from the Economics Ministry, which enoluded that $4,0(0)$ MWe of mocken capacity would be required by the end of the century, assuming a 1.0 percent amnual growth in electricily demand during the intervening period, The Parliament approved the government plan in June 1985.

E1A projects that naclear capacity for the Netherlands in the Lewer Reference case will remain constant at 0.5 (iWe lhrough 2010. The nuclear share of electricity gencration is projected to decrease 103.7 persent in 2000 and remain comstant through 2010. Electrical genceation is projected 10 grow all an anmual rate: of 2.1 percent from 1985 through 2010 . These projections are based on an econcomic: growth rate of about 2.0 percent per year.

The pan 10 eonstruct additional nuclear capacity was shelved, however, in May 1986 hecallse of the Chernobyl aceident. At that lime the government mandaled a full stady of the salecty of, and alternatives lo, nuclear energy. The Dutch goverument has postponed a decision on building additional nuclear capacity until after matemal clections are held in early loges. The safety study was nol compleded in time for the resulls lo be eomsidered in the country's mid-1989) lomg-term planning review of electricity needs. The next such

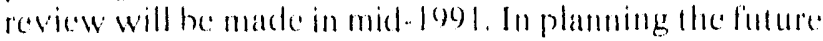
encergy prograna, He government has enphasized cost effectiveness and remalning compretlive whll industrial rivaly in liarope.

\section{Spain}

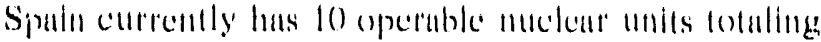

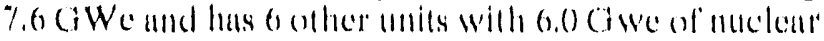
capacity in its construcetion pipeline, In 1984 the Spanish govermment approved its 198.3 National lincrgy

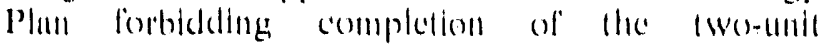
Vuldecaballeress nuclear plant, which was scheduled to go (moline before 19y9. The moratortum was imposed becanse of apparent overempacily of electricity in the country.

In 1989, the Energy Secretary reaflirmed that the National Energy Plan to be published in log) will include " revision of the nuclear moralorium, bul said $\|($ ) decision will be made on the fufure program before then. Many nuclear industry officials are confident, however, that construction on the lwo lanits will restume in the near future. Valdecaballeros I is 80 perecent complete, and Valdecaballeros 2 is 60 pereent complete.

In the Lower Reference case, Spain's nuclear capacity is projected fo increatse $108.6 \mathrm{CW}$. in 20(0), and 10.3 GWo in 2010. LIA projects the anclear share of electricity genciation to decrease form the 1989 level of 37.6 pereent to 23.8 pereent in 2010 . Elecetricity generation is projected to grow all a rate of 2.8 pereent per year from 1985 through 2010 . These projections are hased on a yearly ecomomic growth rate of 2.3 pereent.

In April 1989, Endesa began purchasing stock in Sevillana de Electricidad and other Spanish utilities. The move is thought to be part of a major rearrangement of the Spanish electricity industry to prepare for the opening of the European single market in 1902.

Speculation about the future shape of the industry has centered on a three-way split suid on be favered by the Minislry of Industry. Under the new arrangetnent, Eindesa and Ideduero, anoller Spanish mility, would each control 35 perecent of the marked with the remain.

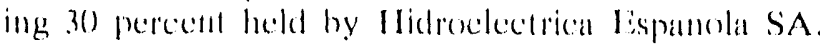
Smaller eompanies wolld be absorbed by llo new grompings, which, it is hopeel, would he latge enough to compete in the new elimate of a bureprean conergy market in the 100()$^{\prime} \mathrm{s}$. 


\section{Sweden}

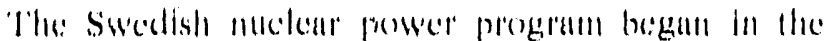

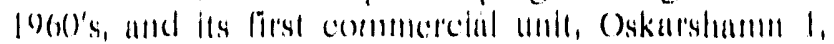
went inlo operallon in 1971. Corrently, Swedents installed nuclear capncily is 9.7 (iWe. Nuclear plants and hydropower each supply about so pereent al the comolly's clecurideily.

During the ge70's sweden experioneed increasing op.

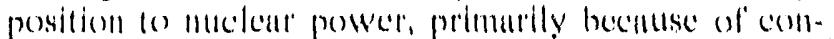

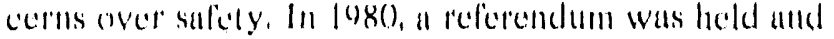

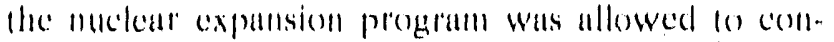
linue. Hewever, in the following year the Parliantent used lle referendum as a basis lore decidlng lo celose all of the collatry's nuclear planls by 2010 .

In reaction to the 1986 Chermobyl accident, the Soclal Democratic government proposed in 1987 and 1988 that the phaseout of maclear power should be speeded up by permancently closing (wo nuclear units in 1905 and 1090 (presumably onc each al Barschacek and Ringals). The proposal was later aceopted by the l'arlinment, In June logs, Sweden's l'arliament denied the Minister of Energy and Envirenment he freedom lo decide which monis wended be elosed in le9s and 1996, ruling that (1) 100() . At that time details of bonth the timing and implementalion ol monnaclear allermativess will be evalualed, and a study will be made of how a molelear phaseout might allect the country's eromomy, comployment and enviromment.

The lis lower Reference case projects hal Swedish nuckent apacily will dectine to 8.6

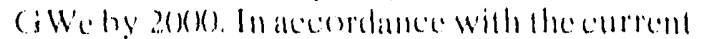
policy for a lotal mocelear phaseoun by 2010, the anclear share of electriceity gencration is profected fo lall from ils loge value of 45.3

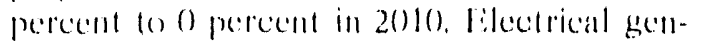
eration is projected fo incerease all a rate of 0.2 percent per year from 1985 morough 2010. These projections are based on a yearly ecere mente groweth rate al 1.7 perecont.

Public discenssoms held in August loge on Sweden's emergy policy have mate il clear that the ruling fiecial

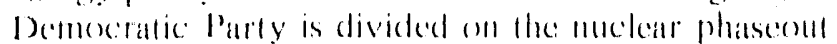
isstle. A social Demoralic working group, formulal-

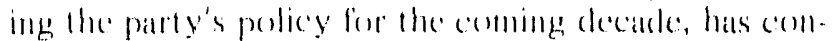
cluded that Parliament made three decesions that are

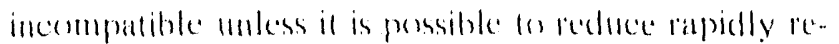

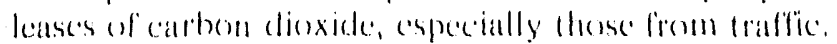

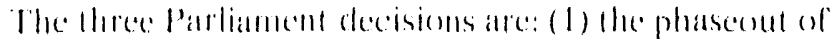

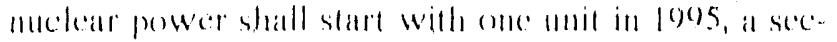

ond tuint in 1996, and the remulning unils by 2010; (2)

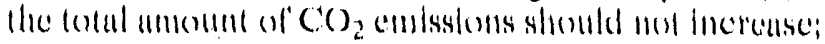

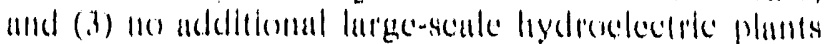
cail be enensertleted.

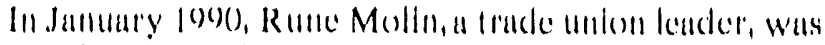

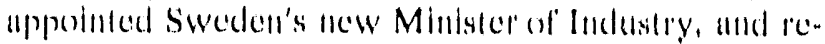
sponsibility for energy policy was translered firom the Ministry of Ronvirommont lo the Ministry of Industry. 'l'his trmaster of responsibility has led some critice io beliceve llau swedents nuclear phasenul might be modilied in log() if'it becomes apparent that early shatdowns of aluclear power plants will lead to high electridedy costs. Il is alleady avident lhat higher prices will posce diflicultices for colectricity-intensive industries, loculed mainly in northern Sweden. Unionized Industries account for once-third of swediste exports. ( )ppositlon to all early, or any, phaseoul of nuclear powver is growing among the trade anions, who claim that He commery's encegy policies in generul, and the nuclear plans in parlicular, will resull in a loss of Siveden's traditional compeditive advanlage basced on low-cost decetricity.

\section{Switzerland}

Switadand correndly has live operable melear units coluling 3.0 OWe and the 1, 140)-MWe Graben unil under construction. In 1989, hydropower aceousued for aboul 57 perecent of the fotal elecetricity produced, with nuclear power sombibuting aboul 42 pereent and oilfired generation combributing flec rest.

In lose llac Swiss lederal government and Parliament canceled the (950)-MWe Kaiserangst maclear muit. The: decision fo leminate the projece was based mostly on ils sile in llace "anten of Aargan, which is very close

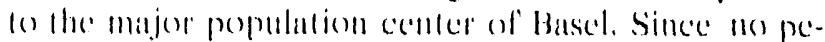

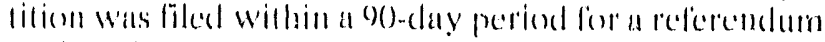
agninst the Kaiserangst decision, He ownel's of the lerminaled nuclear unit will he cempensated $\$ 225$ million as appreved by Parliament. Similarily, the Naliomalral, He lower hemse of Parliamem, moved lo lerminale the cimben project in the Bern cantom, and is secking a similar compensation plan that was awarded to the Kaiscrallgst comsortium members. To help offiset pow

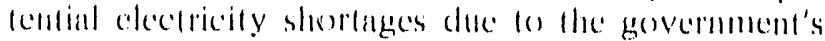
decision, ile Swiss ulility in Bnden will impont an additional 100 MWe of muclear power from firunce, hegimning in 1006. Nordostschescizersche Kraftwerke (NOK), which distribules electricily to nine cantons

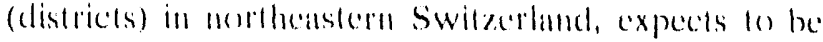
some 30 perecent dependent an imported eleselricity.

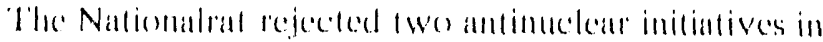

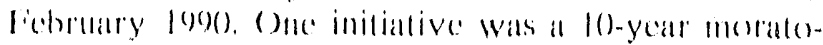
rium (on all ancelear atctivily, while another initiative demanded a ban on finther nuclear eomstruction and

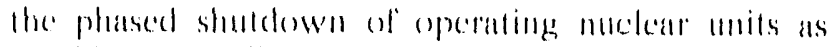
quickly as pessible. Parliament members' arguments contered primarily on the need to keep the nuclear oplion alive for ceomemice and envirommental reatsons. 


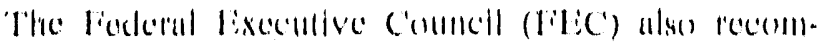

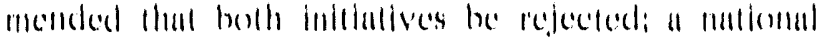

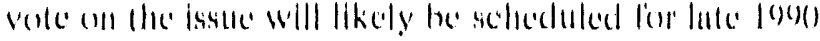
(1) (anly 190$)$.

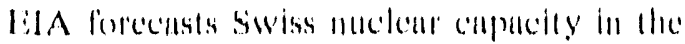

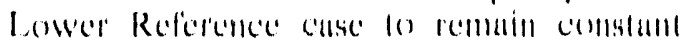

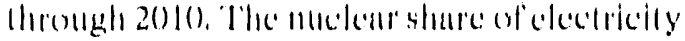
gencration is projegelent to lall to 35.1 percestit ill 2010 (1) from its loge level of 41.6 perecent. Electricily genteration is prodected lo grow an "ralle of 1.1 percesul per yeur fruml 1985

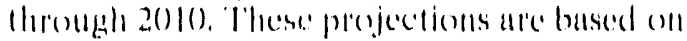

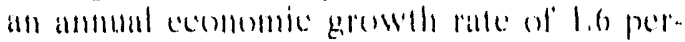
c'ent.

\section{United Kingdom}

The United Kingdom Alomic Linergy Authorily

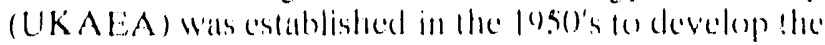
nuclear pregran in Greal Britain, Scolland, and Northcrin Ireland. The nuelear industry in the United Kingdom (U).K.) began in los.3 with the consitrustion of four 50 MWe experimental muits at Calder Hall, which

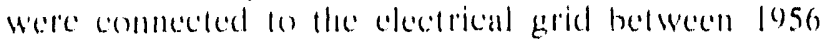

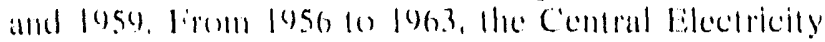
(ienerating Board (CLEBB) of (ireat Britalin ordered eight stations with lwo units each.

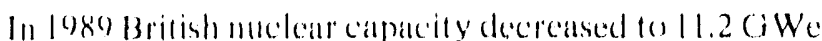
with the shutdown of the Berkeley 2 and Hunterston A2 units. One new unit, Torness Point 2, a 625-MWe advanced-gas reacelor (ACiR) was contected to the gricl in 1989. The completion ol this unit leaves Sizewell Band Hinkley Point C an the sole projects in the British construction pipeline. In 1989 nuclear power plants. pertorming at an average capacity ficeter of 55 pereent, supplied about 21 percent of the U.K.'s total electricial generation. Filectrical demand in the U.K. is corrently rising abeut 3 pereent anturally, higher than the cIeciB's estimated average growth of 2 pereent used to calculate its inventment needs.

In November 1989, the U.K. government announced that the entire nuclear power sector of the clectrice util. ity industry would be withdraw'n from the government's clecericity supply indlustry privatization pro. gram. The original privatization program, annosunced in carly log8, has evolved into a plan to hreatk up the

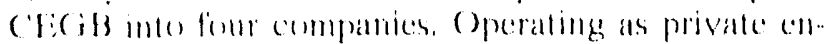

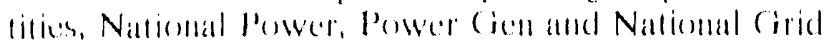
Company will handle nonnenclear operations. The pub. le Nuclear Jilectre Company will be respomsible for the nuckear marked in lenglend and Wales. Scollish Nu-

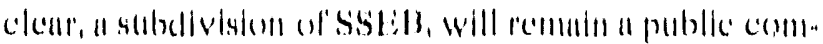

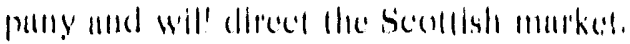

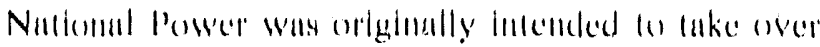

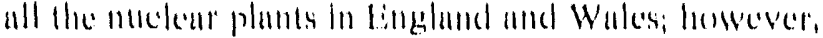

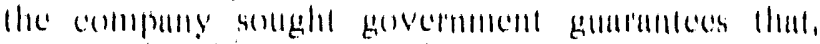

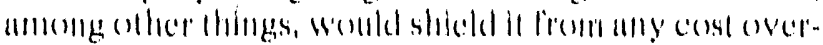

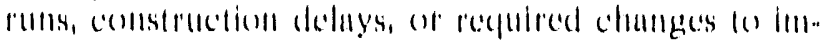

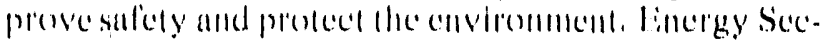

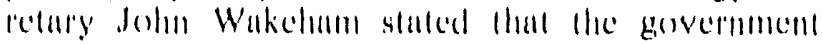

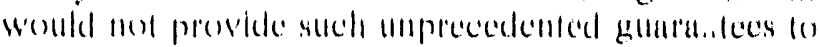
" mivate comprenty and that all of the neclear plants would be hedel in the publice seceter becillese the high

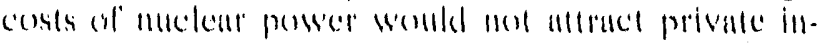
vestmentul.

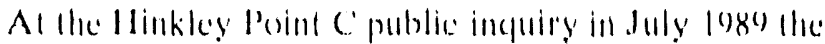

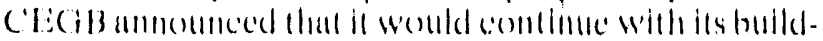
ing applicution for the unit rather than cancelling it as

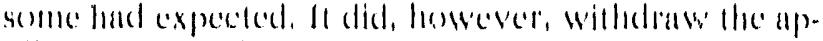
plicution for the remuining IיWRs, Wylfia 18 and Sizcwell C:

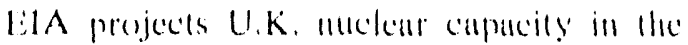
lowere Reforence case lo decrense from lts loge level of 11.2 installed (iWe 108.4 ciWe by $20(0)$, and 1007.6 (iWe in 20)10. The muckent share of electricity generation is prejected 10 decrease from $2(2.8$ pereent in 1989 (1) 12.6 percent in 2(1)10. Litectricily genteration is projected to grow at a rate of 1.5 pereent per year from 1985 through 2010, These projece.

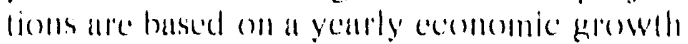
rate of 1.9 perecent.

\section{Non-OECD Countries}

\section{Argentina}

Argentina estahlished a National Alomic Energy Com-

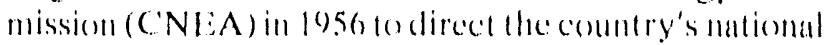
energy plan and control all atspects of its nuckelear techrology. It currendly has awo operating nuclear units with a total net capacily of $(1,9)$ (iWe ats well ats the (1)2-MWe Aluchar 2 under construction. The Atuchat 2 unit is about bo perecent complete and is now expected to go on-line in 10)5; its completion hats beron delinyed by a large fereign debe and hyperinllation.

Both Argentine operating nucleatr mits, Atuchai 1 and Cordebal l, have experienced problems. The Alecha

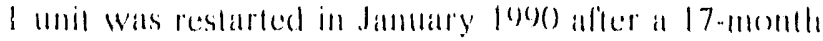

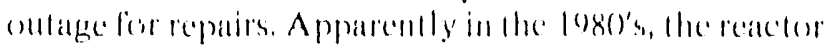


was operalled whllomil andergening regulded full muln.

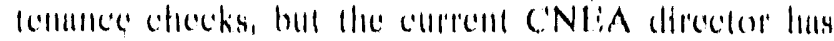
pledged that his adminlsimilon will give the hilghens

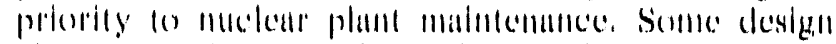

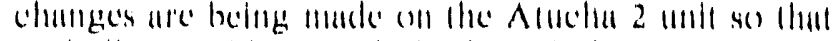

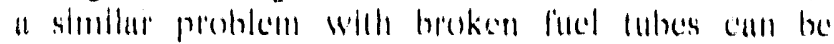
avorided.

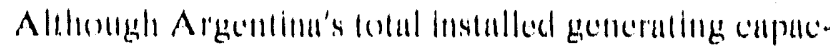
ity is 12,64.3 MW. the system has hoen plagllod will

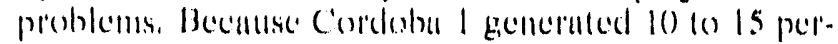
ceill of Argenlinc haselond perwer in 1989, its shutdown in July loge for long-delayed malnemance led for ron taling clectricily blackents in Buenos Alres und olled large cilles. The Ciovernment had delayed its scheduled October logs sholdown heoullse of widespread power shorluges callsed by Alucha I being off-lline and lo-

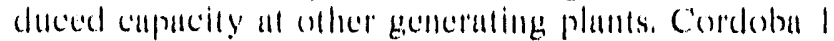
was relurated in service in September 1989.

liA projects Argenting maclenr cupacily in lhe lower Reference cuse lo be 1.8 ciWe by 2010. The nuclear share of electrical generalion is projected fo fall from its loge level of 11.4 perecent 10 aboul 9.5 perecent by 2010. Elecerical gencrution is projected 10 grow al all allmual rate of 3.5 perecent. Thlese projeclions are based on an ecentumice growth rale (1) 3.3 perecent per year.

Argentina is comtinuing its cillorts lo develop an independent finel eyele and beecome a major supplier of

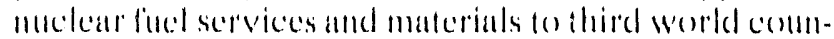
tries. It has signed bilateral nuclear agrecments with al least menty matoms, including Algeria, which rem portedly is interested in the Argentine-designed 38()-MWo Argos PHWR. An agrecment with Brazil extends a nuclear development pact that condel lead to foint construction of the PHWR or ofher Intuclous pewer plants in bolh Argentina and Brazil. However, the heavy debe hardens of Hrazil and Argentima prechade any near-term pregress in muclear power plant comstrictions.

\section{Brazil}

The: Brazilian molear power program began in 1972 wilh the ordering of its omly operable medear unit, the 626-MWo Angra dos Reis I. Angra I began its second

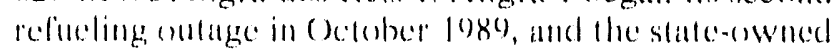

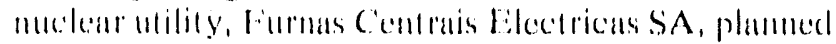
(o) restant it in December lege. However, on a petition freme lowal (ireon Parly politicians, a lower bourl Juelge barred the restart on gerenonds that sutely was inade.

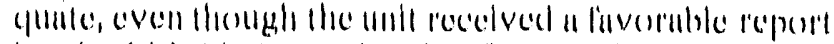

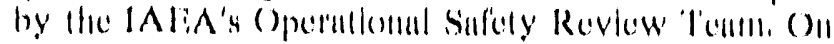

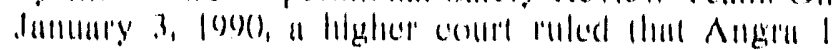

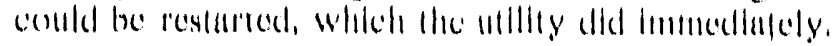

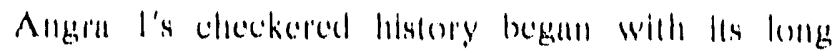

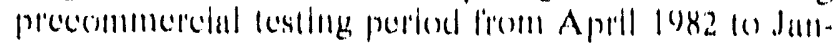

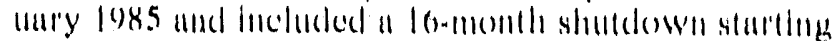

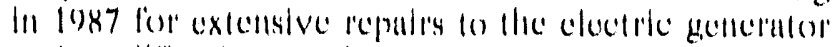

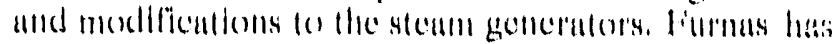
suled the plant's suppller', Westlinghousc, clalmilng lens

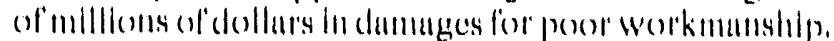
I'he cuse remalns masellled.

Bruzil currently has lwo nucleur units (Angra 2 and ,3)

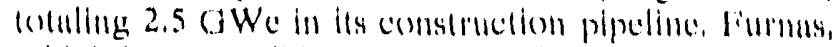
which is responsible for comstrucelion of Angr't 2 and

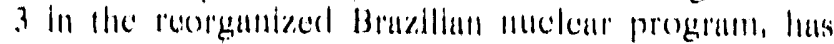

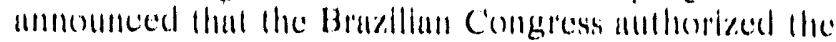

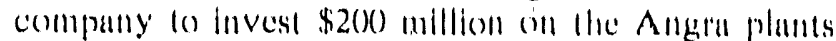
during 1900). The government believes thin power

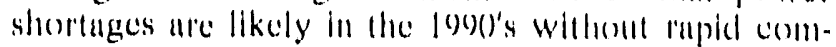
pletion of the Angra fincllities. Angra 2 reportedly is 69) pereent complete, and Angra 3 is 28 pereent complete.

EIA projocets Brazill's mucleur capacity in lice Lemer Reference case to increase firom ils loge level of 0.6 ciWe lo l.9 (iW ine in 20()() and to reach 3.1 ciWe by the year 20 ) 0 . The nuclenr share of electricity generation is promjected lo reach 3.4 percent in 2010 . Eilectricily genteration is profected lo grow al a rate of

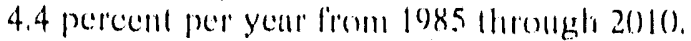
These projections are based on an ecemomice groweth rate of 4.0 perecent ammually.

The 1,245-MWe Angra 2, origimully planmed to be generating by 1093, is now expected fo start operating in lens, necording to the latest evaluations by Electrobras, the Braziliun public electric sector hoter. ing company, Most of the exupment forr Angra 2 is already purchased. 'The unil was supplied by Siemens

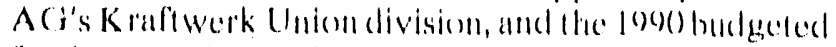
funds are to be necel on equipment installation.

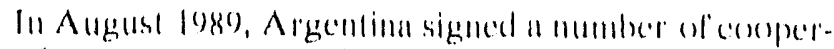
ative ngreements wilh the Brazilian gevermment, including un extconsion of ant existing nutelear develop-

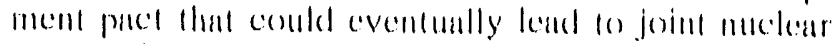
power plant comstruction in both commlries. 


\section{Indla}

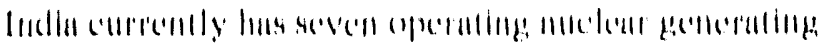

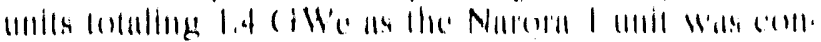
II6)

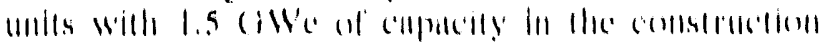

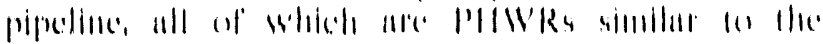

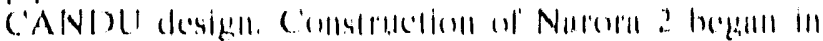

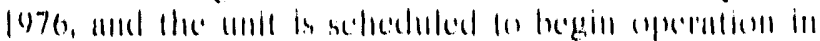

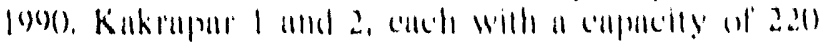

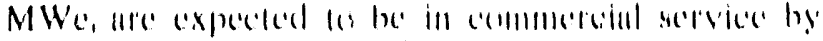

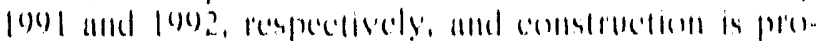

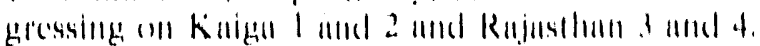

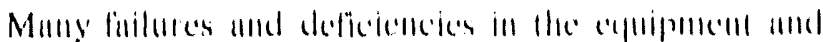

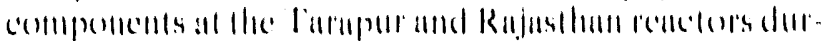

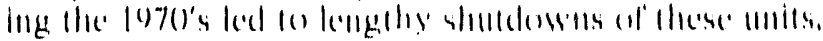

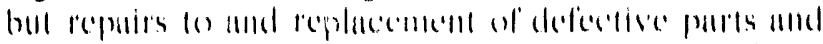

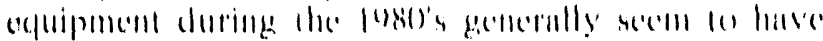

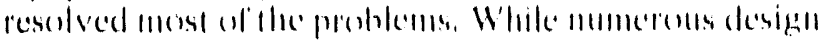

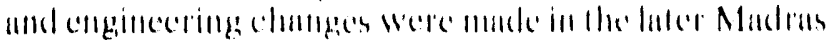

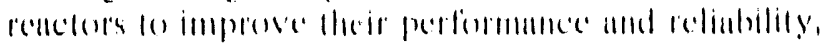

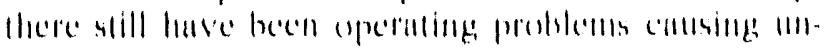

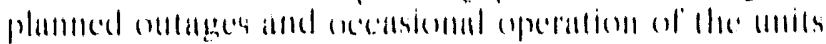
III hulf Iheir designt capracily.

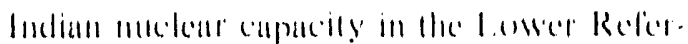

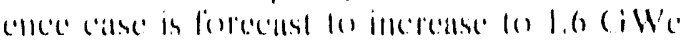

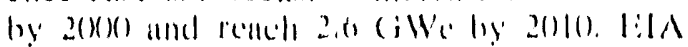

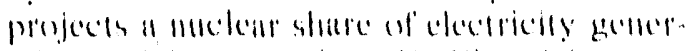

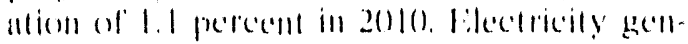

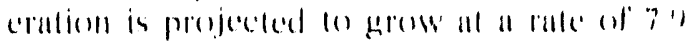

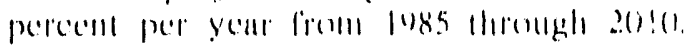

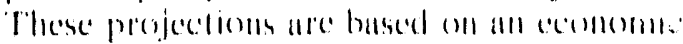

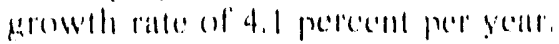

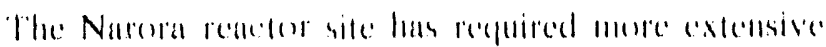

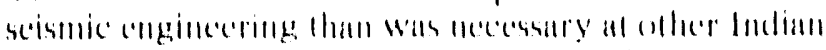

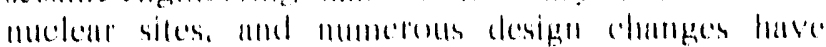

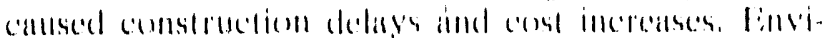

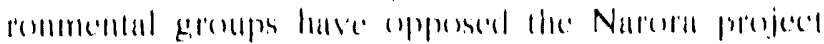

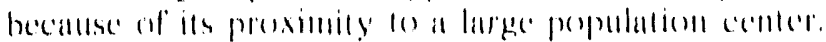

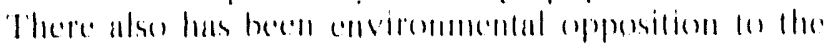

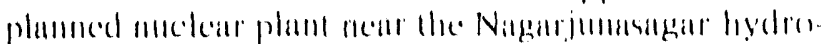

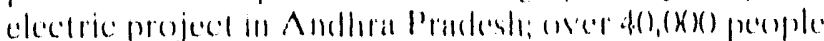

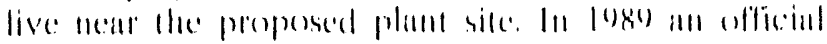

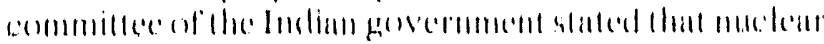

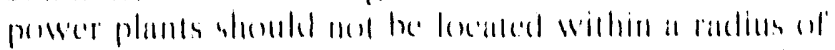

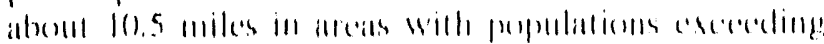
l(1,1)(x) pereple.

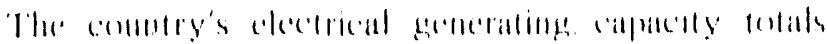

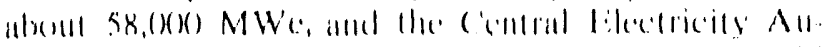

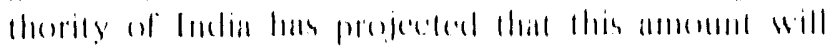

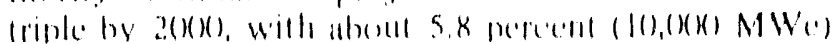

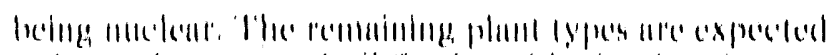

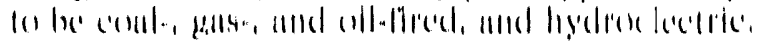

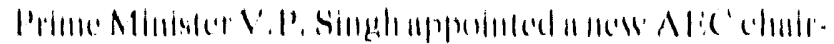

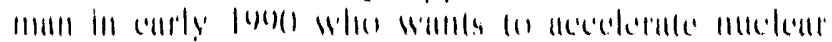

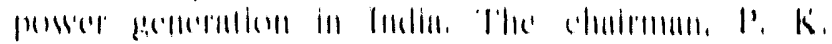

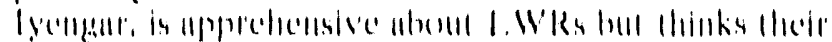

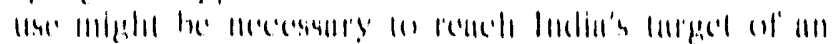

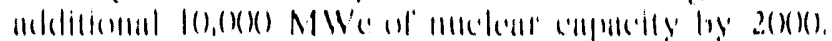

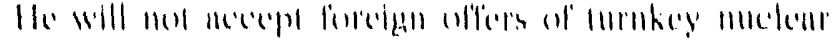

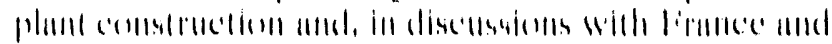

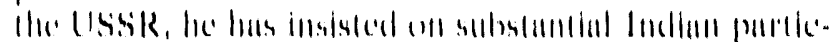

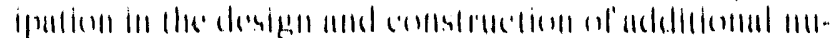

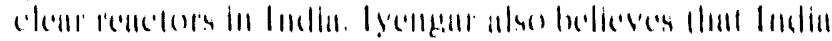

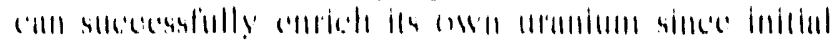

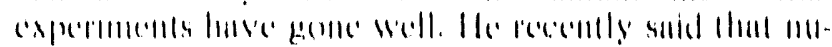

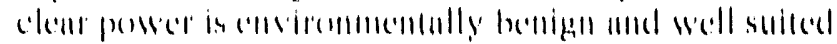

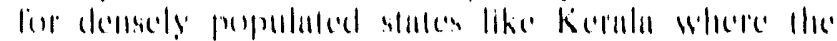

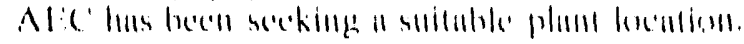

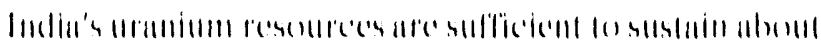

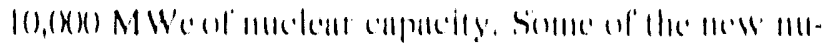

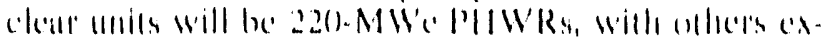

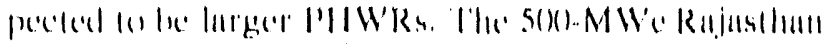

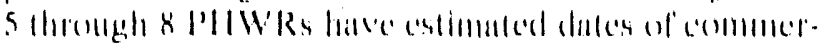

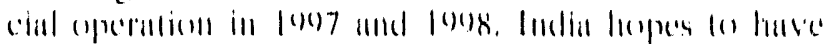

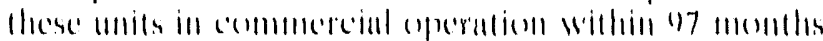

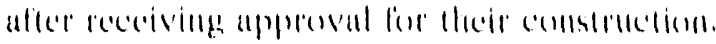

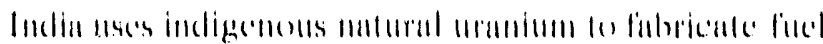

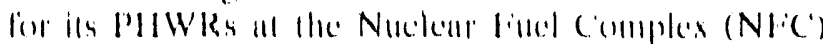

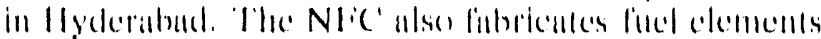

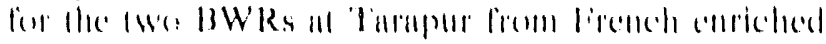
manillul.

\section{Korea, South}

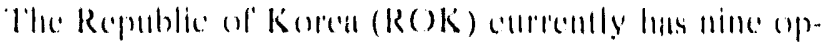

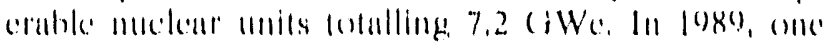

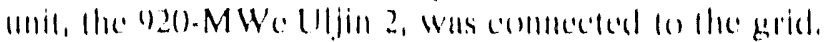

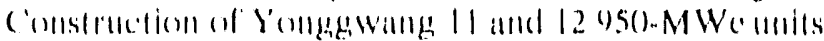

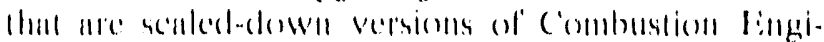

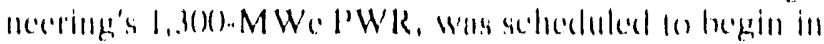

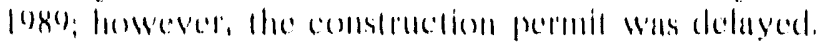

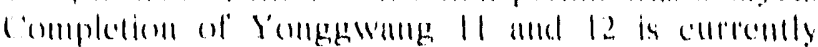

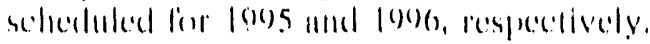

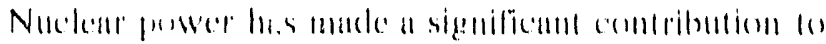

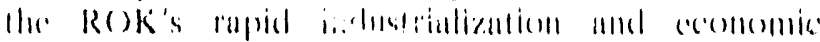

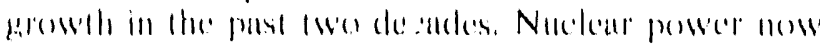

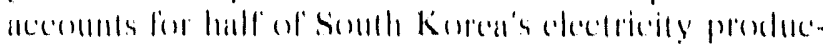
liilli.

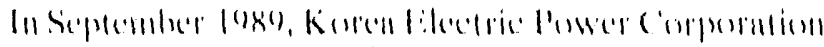
(k)

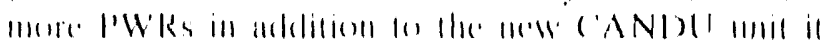

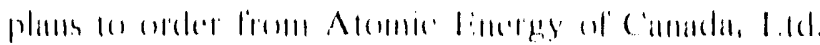

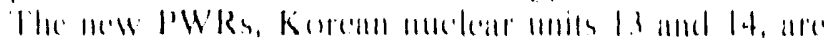

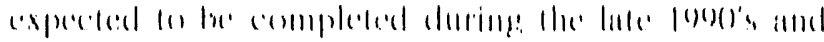

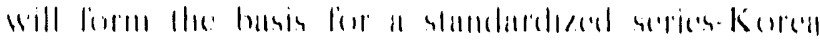

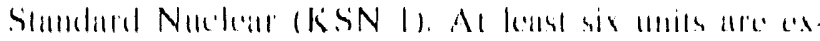




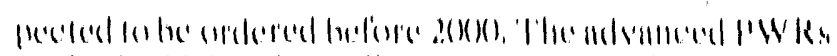

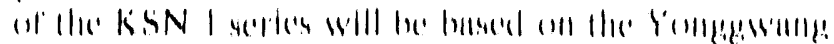

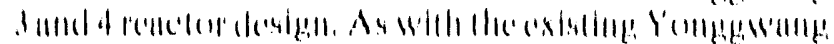

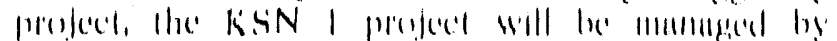

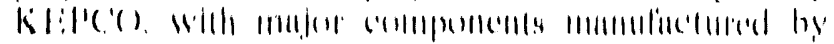

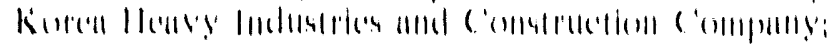

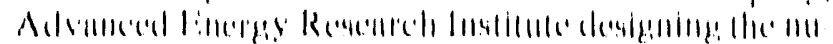

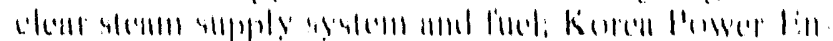

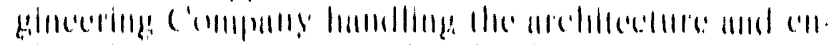
simecorime: iinge Ilus liust.

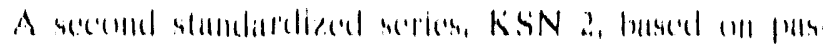

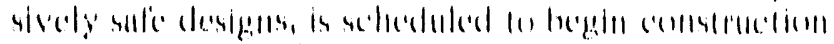

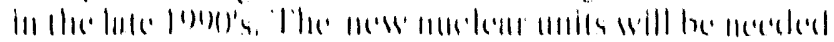

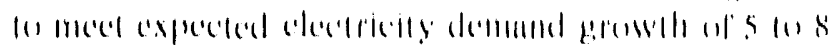

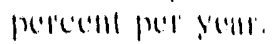

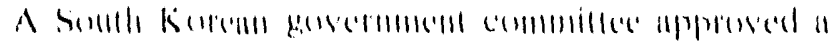

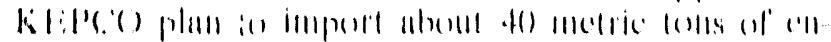

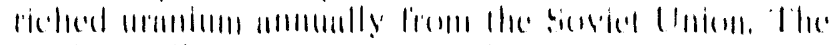

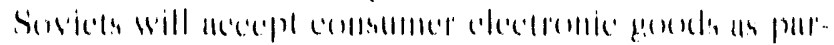

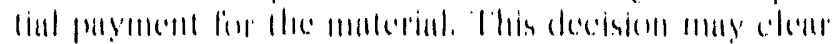

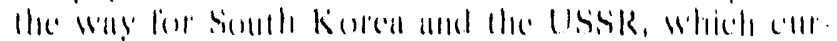

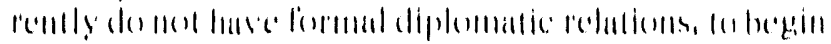

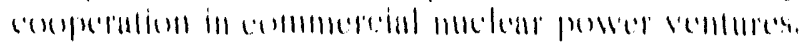

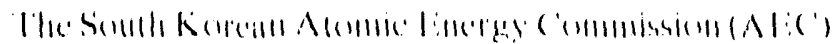

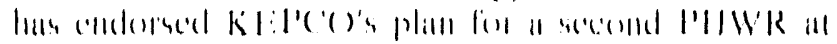

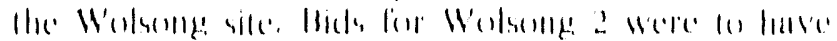

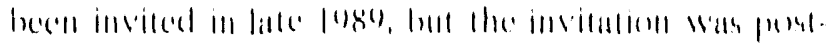

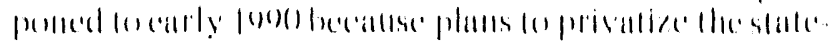

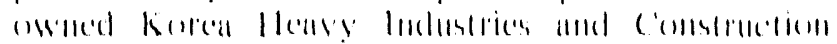

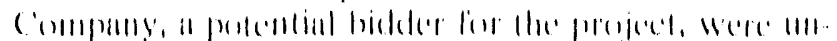
stlecrisiliil.

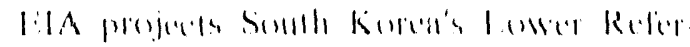

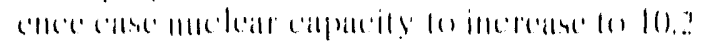

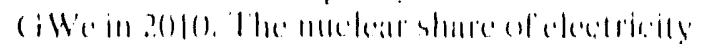

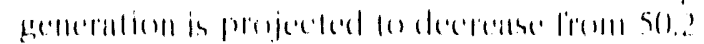

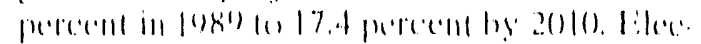

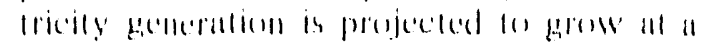

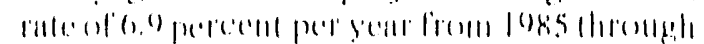

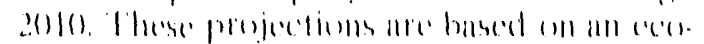

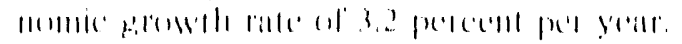

\section{Mexico}

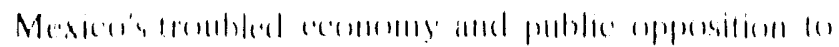

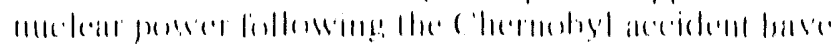

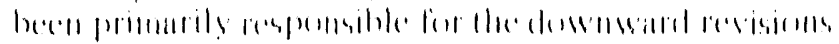

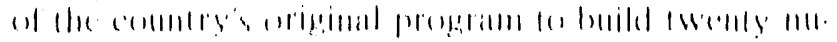

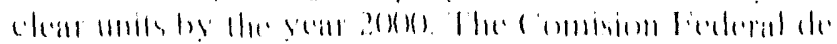

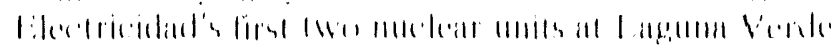

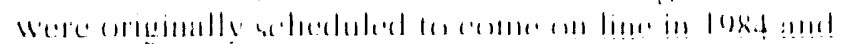

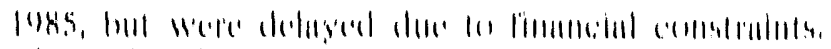

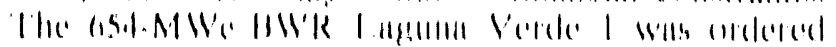

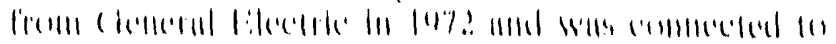

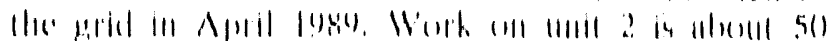

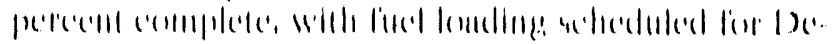

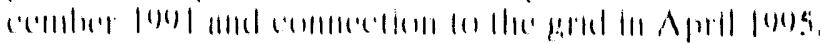

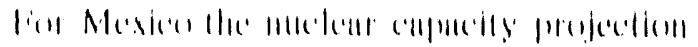

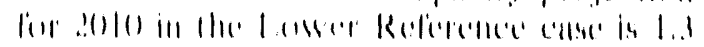

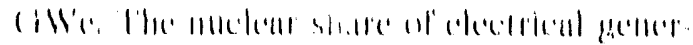

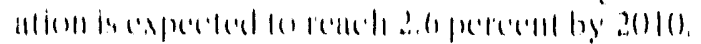

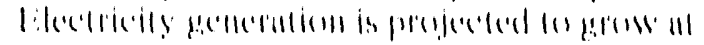

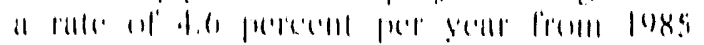

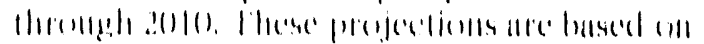

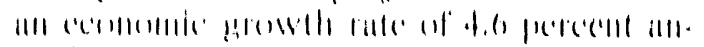
IIIIIlly.

\section{Pak/stan}

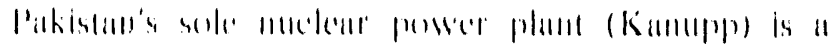

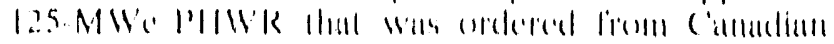

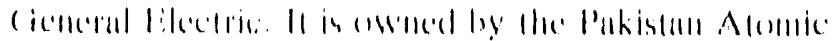
Lancrey (

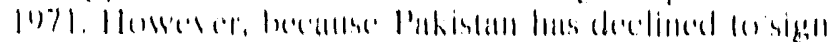

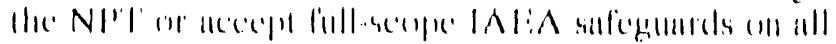

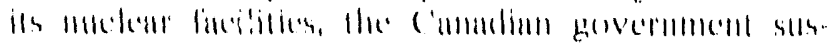

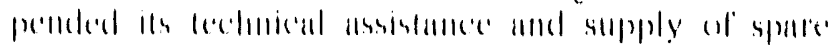

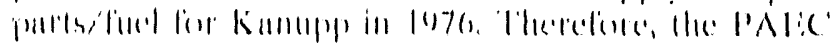

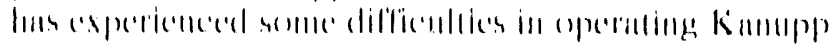

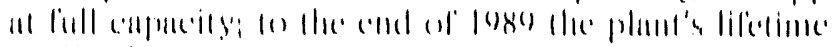

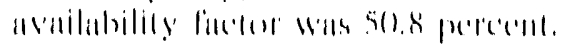

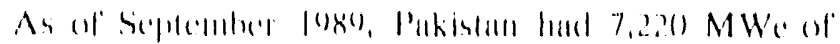

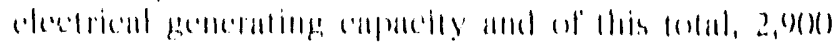

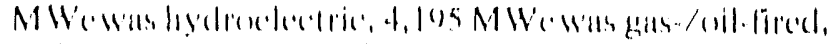

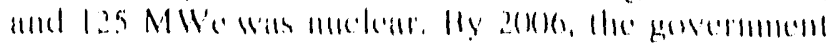

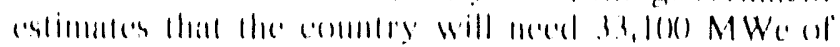

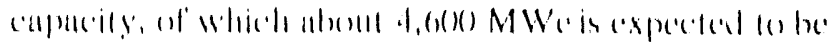
IIIICl'nit'.

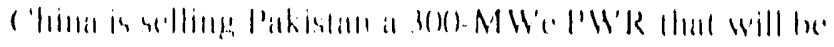

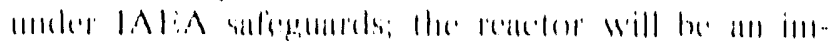

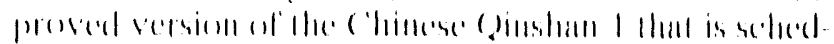

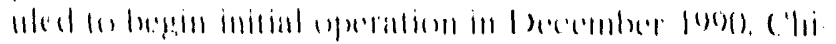

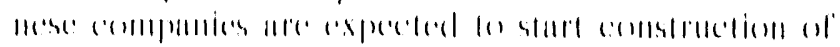

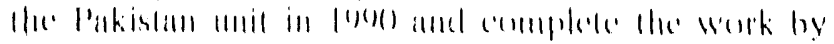

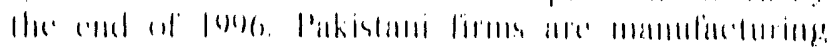

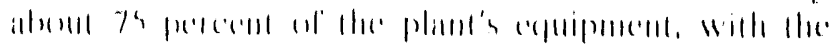

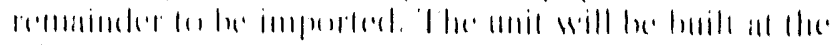

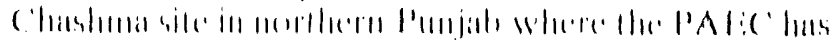

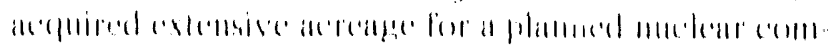

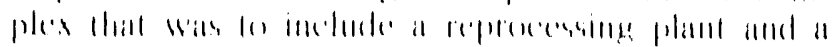

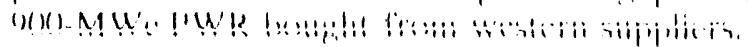




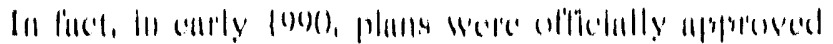

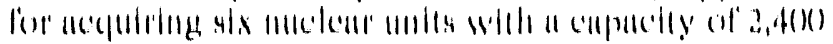

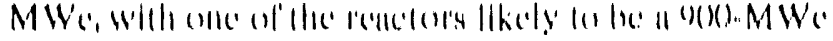

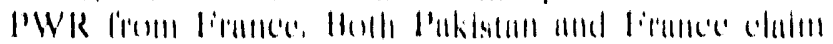

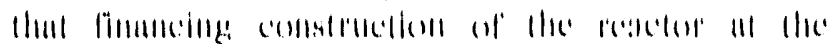

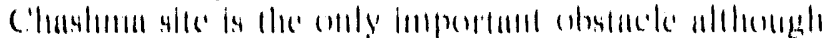

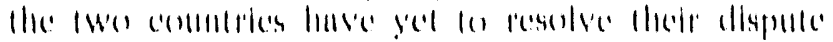

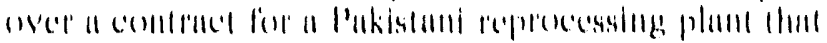

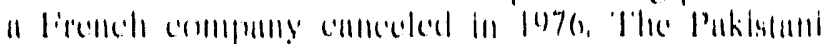

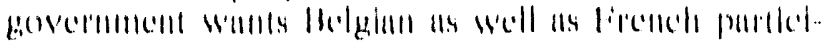

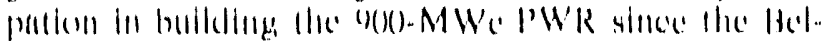

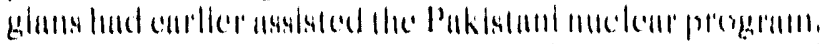

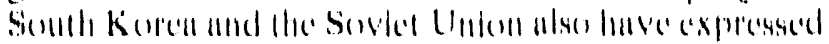

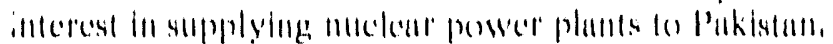

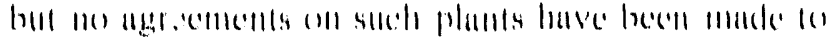
dille.

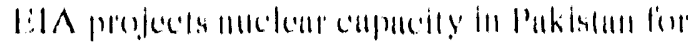

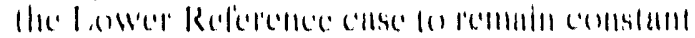

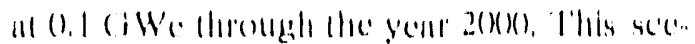

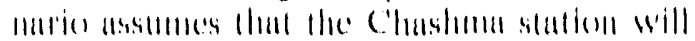

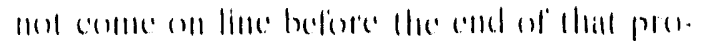

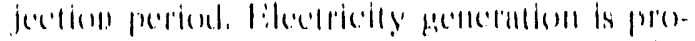

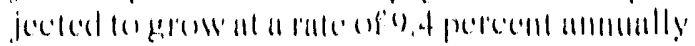

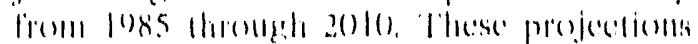

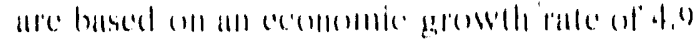
perecent pere yerat.

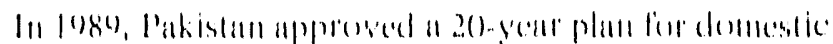

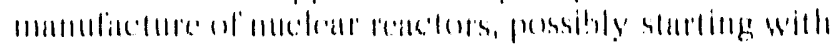

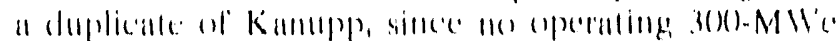

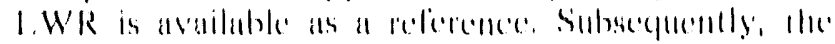

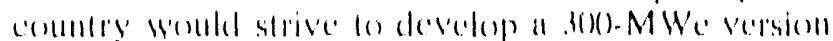

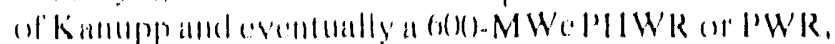

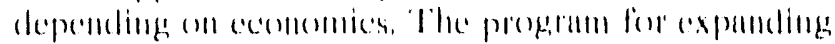

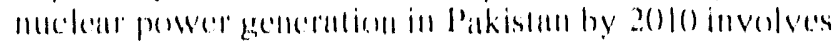

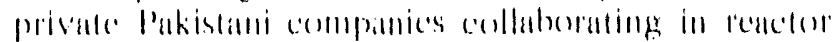

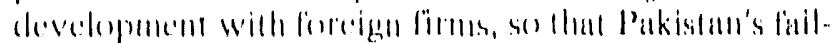

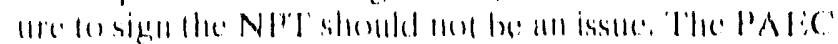

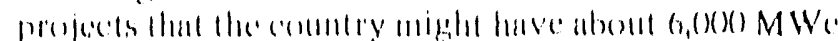

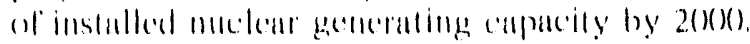

\section{South Africa, Republic of}

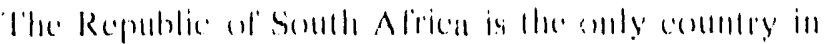

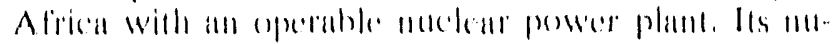

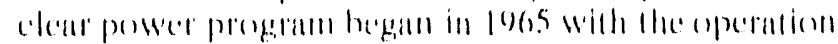

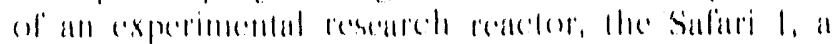

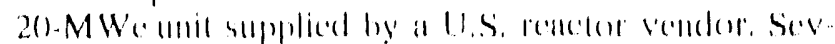

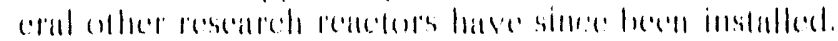

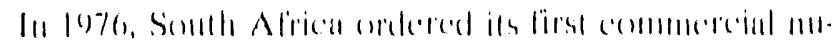

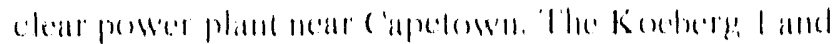

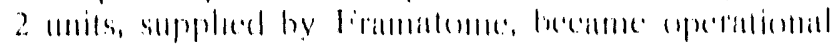

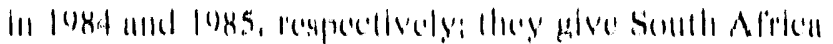

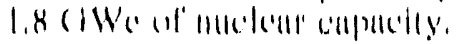

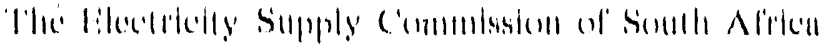

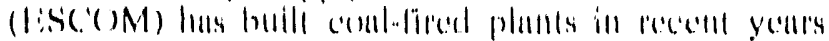

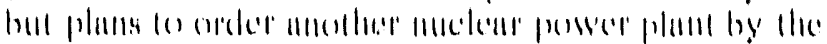

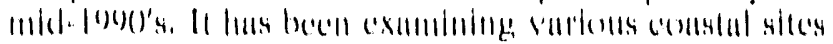

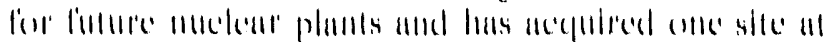
('upe Sil, finmols.

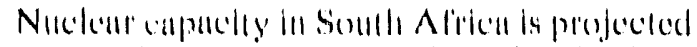

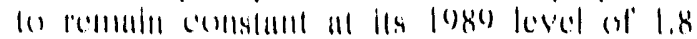

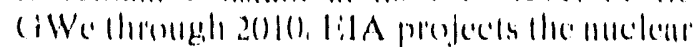

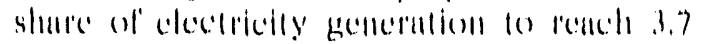

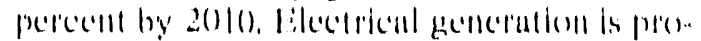

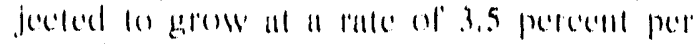

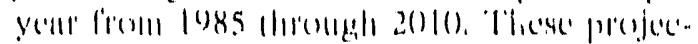

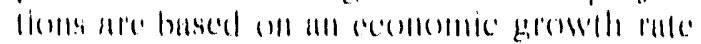

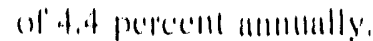

\section{Taiwan}

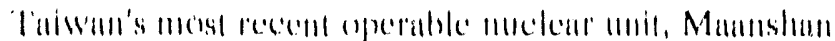

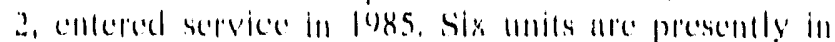

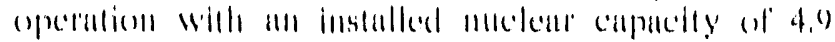

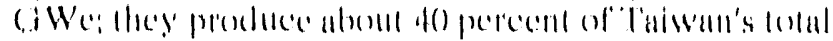

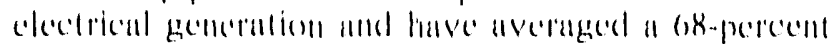

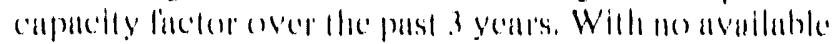

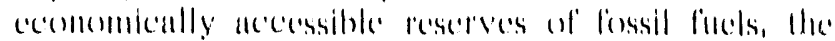

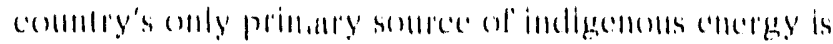
livelomelecerice poweres.

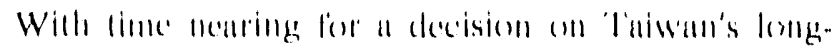

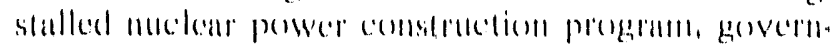
ment and political leaclers have beginn to lake sides

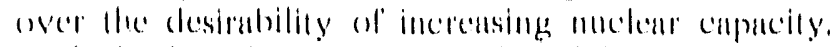

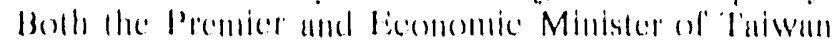

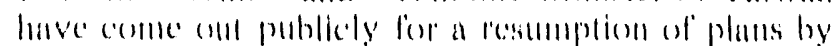

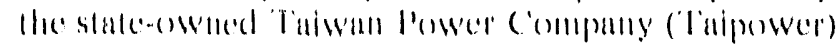

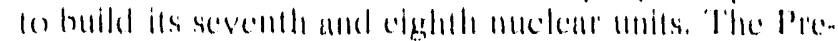

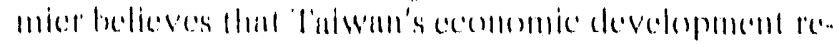

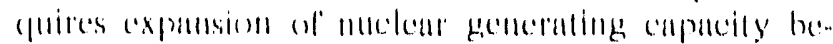

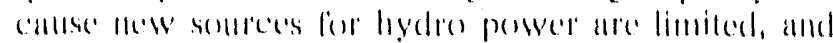

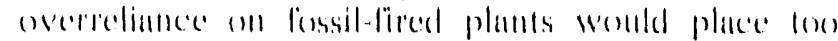

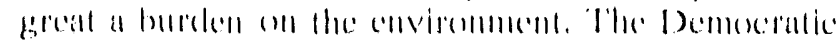

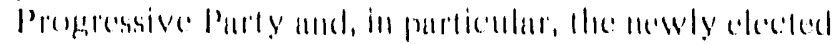

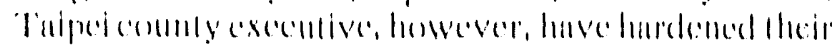

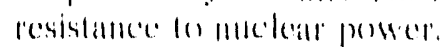

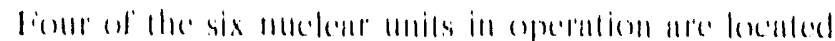

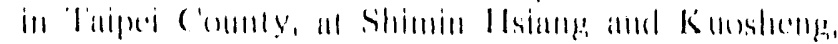

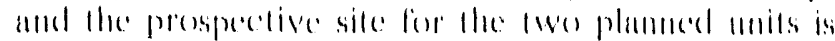

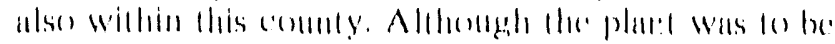

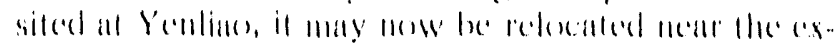

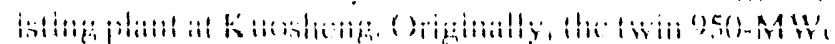


units were to have been in operation in the early 1990 's, but an equipment contract was canceled in 1982. Government officials cited a decline in electricity consumption forecasts as the basis for their decision and said they would revive the project in a few years. Antinuclear sentiment grew in Taiwan during the 1980's, fueled by the Chernobyl accident and suspicions about Taipower's safety capabilities.

Taipower plans a campaign to win greater support for nuclear power, as it believes the two units need to be operating by 1998 and 1999 to avoid serious power shortages. The utility may take several steps to win public support, such as subsidies to local communities; provision of free electricity in the region near plant sites; and upgrading the safery, reliability, and availability of existing nuclear plants.

EIA projects that Lower Reference case nuclear capacity in Taiwan will remain constant at 4.9 r.je through 2000 and grow to 6.3 GWe by 2010 . Taiwan generated 35.2 percent of its electricity from nuclear reactors during 1989. This percentage is expected to fall to 21.3 percent between now and the end of the projection period in 2010 . Electricity generation is projected to grow at a rate of 4.4 percent per year from 1985 through 2010. These projections are based on an economic growth rate of 3.3 percent annually. cilities until $2(x)$. The new bill specificully prohibits for an indefinte period the construction of nuclear plants, the preparation of nuclear-related investment programs, and technical documentation for nuclear plant construction. The $\mathrm{FEC}$ draft allowed site studies and other preparatory work leading up to but not inciading a final investment decision.

The current law allows but does not define "scientilic research and development research." While it permits mining-geological exploration, geological-seismic research, and nuclear waste management activities, the law terminates federal funding of research related to nuclear energy safety. The new law does not refer to the operating Krsko nuclear power plant; rather its intent is to block government-supported plans to construct four 1000 MWe ruclear units by 2002 . Although 3 years ago an electric utility consortium asked for intermational tenders on these units, no final vendor recommendations were announced because of the construction program's suspension.

EIA projects Lower Reference case nuclear capacity in Yugoslavia to remain constant at its present level of 0.6 GWe through 2010 . The nuclear share of electricity generation is projected to decline to 1.6 percent by 2010 . Electrical generation is projected to grow at a rate of 3.6 percent per year from 1985 through 2010. These projections are based on an economic growth rate of 2.2 pereent per year.

\section{Yugoslavia}

Yugoslavia's only nuclear unit, the 632-MWe Krsko PWR, was ordered in 1973 and began operation in 1981. The more industrialized republics of Yugoslavia have been forced to meel energy demands by importing large quantities of oil and electricity. Experts have been concerned that existing fossil-fuel generating facilities would consume all of the country's coal reserves in a short period of time. Revised government plans for energy development apparently will emphasize domestic resiources, chicfly coal, oil, and gas, and will forecast reduced energy demand. The plans do not become official policy until adopted by all Yugoslav provinces and republics. Currently. Yagosiavia plans to add $5,0(0) \mathrm{MWe}$ of hydroelectric capacity by $20(0)$.

In June 1989 the Federal Chamber, the upper house of the Yugoslavian Parliarnent, revised a hill drafted by the Federal Executive Council (Fec) that had called for a moratorium on construction of nuclear fa-

\section{Countries With Potential or Inactive Nuclear Power Programs}

This section explains briefly the present status of countries with potential or inactive nuclear programs.

\section{Bangladesh}

In early 199(), the president of Bangladesh ordered the country's Atomic Encrgy Commission to determine the avalability of loans from Istamic countries for the comstruction of a $30(0-10.50(0)$ MWenuslear power plant at Rooppur. Demand in the region is projected foreach $1,200 \mathrm{MWe}$ by 1095 , so that new baseload capacity is needed in western Bangladesh. 


\section{Egypt}

Egypt and Argentina signed a nuclear cooperation agreement in November 1988. This pact may give an edge to Argentina's proposed Argos design for a 380-MWe PHWR if Egypt decides to order a nuclear unit. Egypt had previously been negotiating with Kraftwerk Union of West Germany for a 1,000-MWe PWR unit.

\section{Indonesia}

In 1986, three consortia of reactor vendors submitted proposals to the Indonesian government for construction of a $600-\mathrm{MWe}$ nuclear unit. The proposals called for build-operate-transfer (BOT) arrangements which have yet to be used in bringing nuclear power to less developed nations. Indonesia has never accepted any of these proposals. In early 1990 it made a third request to the Japanese government for financing a feasibility study and site determination for an Indonesian nuclear reactor; this request reportedly is for $\$ 9.3$ million. The feasibility study could take 4 years to complete. The Japanese government is expected to decide on the grant request by July 1990.

\section{Iran}

In 1979, the Iranian revolutionaiy government canceled contracts for two 1,300)-MWe PWRs at Bushehr; the contracts had been signed with Siemens/KWU in 1974. Since 1984, Iran has been trying to reactivate the project with foreign assistance. In early 1990 the USSR agreed to build two 440)-MWe nuclear units in I ran and to assist that country in completing the Bushehr reactors. The Soviet-Iranian agreement, it is reported, also includes Iranian export of natural gas to the Soviet Union beginning April 1, 1990.

\section{Israel}

Israel has never signed the NPT but is willing to allow IAEA inspection of any nuclear power plants built in that country. Israel has also negotiated with Canada to purchase a CANDU reactor that would be constructed at Shivta in the Negev desert. Isratel expects its next power plant to be nuclear; the capacity of that reactor apparently will depend on which vendor supplies the unit.

\section{Philippines}

The Philippine government has, for political reasons, never authorized startup of its 620)-MWe PNPP-1, which was completed in 1986, despite prolonged power shorlages in the Manilat are... 'ts lawsuit agganst Westinghouse, the PNPP-I vendor, has continued, and may not be settled for some time although most of the counts have been referred for settlement to an international arbitration body. The litigation charged Westinghouse with plant deficiencies and bribery in its construction.

\section{Turkey}

The Turkish government still wants to build a nuclear power plant at Akkuyu but has postponed a final decision in the matter. It is no longer negotiating with Atomic Energy of Canada, Ltd., for a 600-MWe PHWR. However, in May 1989 it was reported that Turkey expected to sign a letter of intent with an Argentine firm, Investigaciones Aplicadas, for a modular 25-MW Carem $15 \mathrm{LWR}$. The unit would be sited near Ankara and used for baselon power. If the small reactor works well, Turkey may ultimately decide 10 buy the Argentine Argos PHWR.

\section{Countries With Regulated Market Economies (RME)}

Over the past year the Eastern European countries of Bulgaria, Czechoslovakia, East Germany, Hungary, Poland, and Romania have experienced dramatic political changes. In each case the change is awaty from central economic planning and toward a market driven economy. This is a critical change from recent practices and will influence the direction and pace of nuclear power in all non "western" countries. The changes or shifts in the decision-making criteria include increased considerations for:

- Safety and risk

- Environmental impacts

- Public preferences

- Availability and cost of capital

- The changing political climate in Europe

- Economic costs/benefits

- Balanced power supplies.

In RME countries, each at a different stage on the path toward a free market economy, the role and status of nuclear power is being systematically reevaluated. The outcome of the reevaluation will influence the operation of existing power plants (nuclear and conventional), and the completion of planned power plants.

All the regulated market economy (RME) and centrally planed economy (CPE) count rics with operating nuclear plants or with nuclear plants under construction have critical shortages of electric power, and coal generates most of their power. In many cases coal is burned in inefficient, highly polluting plants with little: 
or no pollution control equipment. Other sources of electric power include hydropower, natural gas, and imported electricity.

In many of these countries, however, nuclear power is likely ou represent a smallet fraction of the electrical power capacily than previously planted, and in some of them nuclear power may be completely eliminated. This is due to several factors: (1) the lack of capital; (2) the know-how to comstruet and operate nuclear power plants and (3) the 1986 Chernobyl accident.

This section summarizes nuclear power programs in countrics with RMEs. Only those countries with nuclear capacity that is operable or scheduled to be constructed are comsidered. Tables $\mathrm{Hl}$ and $\mathrm{H}_{2}$ list the operable nuclear generating units and those under construction for RMEsand CPEs (see next section). Every effort has been made $f(1$ assure that the best avalable information is incorporated into this section; however. the reader is cautioned that data soneres for these contitries ate not as reliable or as prevalent as those used for the market countrices covered in the beginning of this chapter.

This chapter is compiled from various somrces that resesent their data differently and may contradict information in other publications. ${ }^{58}$ four RMEs and one CPles had operable nuclear capacity in 1989 and prom duced a lotal of 274.2 net terawalthours (TW/1) from 66 units. This was 13.8 pereent of their total electricity generation."

\section{Bulgaria}

Bulgaria currently has five nuclear generating units in operation tolating 2.6 (iWe and another 4.8 ciWe of nuclear capacily in ils construction pipeline. The fous 408-MWe and onc 953-MWe Kondoduy VYR PWRs produced 35.0 pereent of the conntry's electricily in 1989. The monts operating or under comstruction were supplied by Alomenergonexort of the Soviet Enion. Kozloduy 6, another 953-MWe PWR, is scheduled for connection to the grid in 1990 .

In lo88, C'zechoshlovakia's Stoxda Works was awarded the contrace for the lirst 953-MWe macleat unit to be constructed at the Belene sife. Comstruction has been delayed, with the statup for Belene I sefeduled for

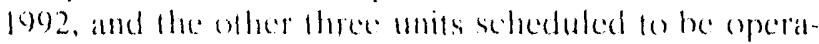
liomal at 30-month inlervals thereafter However, no meclear eompenents have yet becen delivered for the Belenc I mail, and little comstruction werk has been donce on betene 2. After demonstrations against the nuclear plant in carly 190(1), He Bulgarian governoment suspended construction work and appointed a parliamentary committec to study the need for power and the safety of the Belene plant. The parliamentary eommitlee will study: (1), whether increased efficiency can sufficiently reduce enctgy consumption; and (2) the probuble seismic risk in the Belene area which suffered a strong earthquake in 1974. After that earthquake, the Soviat Union improved the seismic resistance of its later VVERs. The eommittee expects to discuss the seismic issuc with nuclear experts in western countries. To date, these foreign experts have judged that the Bulgarian design containnent at the Belene plant provides mote than adequate sufety. Bulgaria believes that the Soviet VVER-I(x)0 reactors have a large margin of' saf'cty.

\section{Czechoslovakia}

Coechoslovakiat operates the four-unit Bohunice and Dukovany nuclear plants with an instalted capacity of 3.3 GWo. These eight VVER-440) PWRs produced 30) percent of the comntry's electricity in 1989. Among countries that formerly had centrally planned economies but are now evolving into new political and economice structures, Czechoslovakia is second only to the Soviet Claion in both operable nuclear capacity and nuclear capacity under construction. The current Crechostovak encrgy plan calls for installed nuclear capacily to increase $1010,300 \mathrm{MWe}$ by 2000 , a lotal which would exceed coal-fired capacity for the first time and would generate 61.8 million $\mathrm{kWh}$, or, 59.7 percent of expected clectricity generation in that year.

The Crechosilovat Alomic Energy Commission planned to decide in earty 1990 on the basice safety of the Bohnonice I and 2 moits that ane similar to the East Cierman VVI:R-440 mits in the Greifswald region. liwe of the latter reactors were shut down in early 1)(9) after a safely review. However, work on the Bohumice units began 4 years after construction started (n) the bats (iermain Nord 1 and 2 PWRs, so that the Cecelesslovak reackers incorporaled improved component design and mandatedure, including highor quality Cachostovat materials and betleg quality assuratloe than in onler Sovictedesign VVlaks.

Siemens/KWU diagnestic systems lo improve salfely have been installed al the Dukovany PWRs and will be phaced at the Bolmuice plant by 1001. The West (ierman company has offered to imponve reacedor safoly in Cecohostovakia, and a West German official planned (1) visit the enuntey in April 100() lo discuss further lichonology transfors

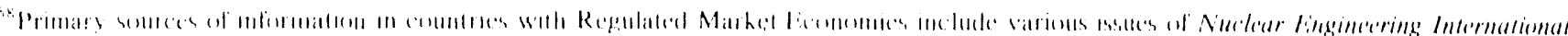

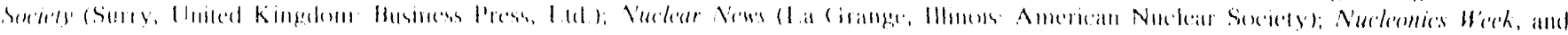

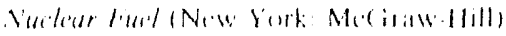

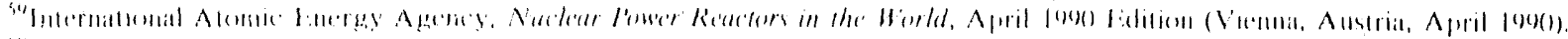

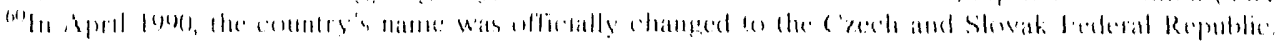


Ceechoslovakian and other Bastern toropean officials agree that the Soviet-resign instrumentation and cont-

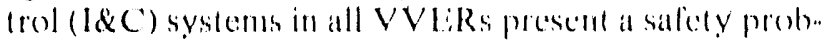
lem. Moderneleceromies as wedl ats saledy improvements to their pressure vesseds are needed in these reactor systems to ensure proper operation.

The 380. MWe Mochovee I unit had been scheduled to begin operation in the latl of loge, but ifs startup was first delayed to September fog) and then delayed again (o) 1902. The unit's I\&C system may undergo a complete examination and potential reconstraction. Caechoslovak oflicials insist that the delay was unrelated forecent lece poblems at the Gast Cierman Nord units. The Cocohosilorakian l\& system was designed jointly with the Sovicets, and is unique to the second gencration VVERs ander construction al Mochovece.

The Cacehoslovak energy minister suspended construction work on the Temelin 3 and 4 units in Jannary 1090. However, work is to eontinue on the lenelin I and 2 units that are scheduled for completion in 1092 and 1904, respectively. Austrian experts will be in. volved in studies designed lo britg the sallety of Temelin 1 and 2 up to Western standands. Environmentalists in Coechoslovakia have criticized the eountry's nuclear program in general and the four propesed VVER-10(0) reaters al the lemelin plant in particular.

A Cacehoslovat official in the fuel and energy mintsery believes that the Temelin 3 and 4 units will either be canceled or redessigned to incorporate western tech. nology. The Caechoslovaks have discussed the possible participation of Western reacerer vendors in completing these Temelin units. Because of other prientities and 1890 alections, the new government may not decide: on the future of the Temelin plant for seme lime.

Ceechoslovakian lims have been actively involved in the effort of the Conncil for Mutual Fonnomic Assis. tance (CMEA) combtries to share in the manufacture of hardware in Sovict-designed maclear reactors." They supplied 80 perecent of the hardware for the Temelin units as well as some heavy moctear compronents for reactors in the USSR and ofleer mations in Eastern Europe

Electricite de France contracted with Cacehoslovakia in 1989 fo supply software for its nuclear units. The: French Commissariat a l'Energic: Atomigue (CLA) plans to strengthen its conperation with Cacehostovakia in forter gencral areas: (1) sufely, including component aging and uplating, procedures for reatefor operation; (2) design of ofew, improved reatefors; (3) the fuel cycle, especially spent finel storage and dismantling of nuclear facilities; and (4) tranimg programs for (coch. oslovatkian students at firetich mochear engincering schools and rescarch laheratorices, The C'VA programs

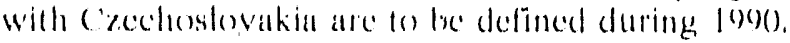

\section{Germany, East}

Last Cinmany currently has six operable moclear generating dunts lotaling 2.1 GWe (Nord 1-5 and Rheinsberg, and has nine olher units with 6.6 (iWe of nuclear capacity in its construction pipeline. Nord 6 through 8 are Soviet VVER-440s, while the six Slendal units are VVER-10(0)s. All hese reactors were initially schediled to become: operational in llace early logots, hut their comstruction has been delayed for a variety of reasoms, The East Ciermans' highest nuclear priority will be to eomplete the remaining. Nord units. In 1989 muclear energy suppliced aboul li pereont of tass (iermany's clectricity.

Eilectricity demand in the (i1) R is estimaled lo increase by 2 pereent per year, and possibly more as a result of closer political and ceonomice ties to West Cicrmany. liast Ciermany will need about $8,()(0) \mathrm{MWe}$ (n) new and replacement generating sapacity in service by $2(0)(0)$, at least half of which is likely to be nucleatr.

The (ierman Democratic Republic (GDR) held elections in March log) to establish a carcetaker government that conld gevern the country prior to its ultimate reInification with West Ciemany. There is an uncertain future for $\vee \mathrm{B} B \mathrm{Kombinat} \mathrm{K}$ raftwerksanlagenbau mbH (KAB) that built the Nord 1.4 moits. A reunified Germany will privatize the $\mathrm{K} A B$ and other state-owned entities in the (BD)R. The KAB is awating a Sovict decision to supply heavy components for he stendal 1 and ? units hy the Spring of 1992 although a West Cierman nuclear official believes llat Sirmens $A G$ / KWU will step into the picture if the USSR fails to act expeditionsly. Also, the new (ieman govermment may decide that the Stendal reactors should meet westeron saliety standards.

A January fog() agreement between West and East Cierman officials provided for expert panels fo cooperalle in four areas: (1) harmonizing the nuclear fuel cycle of the two comntries; (2) mifying (icman nuclear law on the basis of the West Cicrman Atomic Act; (3) nuclear materials transporl: and (4) waste management. The first pance is responsible for unifying nomcommercial fied eyele policy and regulation although the ultimatle role of industry in waste management programs is expected to he disceused in the near future. West (iemoan officials are: anxious to have (me set of Waste conditioning practices throughont at unified (jerman state. They also want to learn the dedails of Soviet

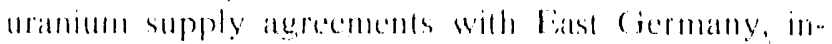

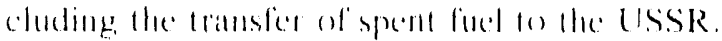

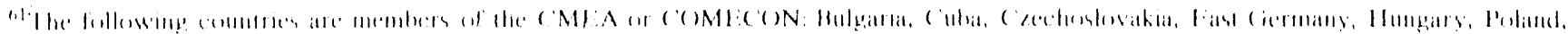
Rullanlat and lissk.
} 
East Germany and the USSR currently have a firel

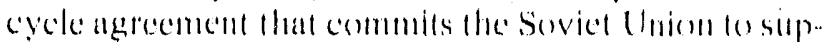
ply fleste fued for the lifetime of the Nord and Stendal

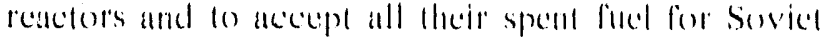
reprocessing. This agrecoment applices apparently on the lon Sovicl-elesign l'WRs in eperalion and under contstruction at the Nordand Slendal sites. Hewever, since the GDR Wanls its future unts lo be of Western design, it hopes that the Sovicts would agree to furmish liesh fuel for Western reacelors and take basek their spent fied, so that East cicomany does mol have fo mosest in a spent filce waste managerment plan for a small mumber of Western reacters.

In carly f(0)(), a West (icrman reactor saley agency reported embritflement to the pressure vessed on the Nord I and 2 nuclear lunits in bast Gormalny, which arcearly Sovied-design V V FiR-440s, The safety agency advised shouting down both reactors until lechnical cuestions on their sallety are resolved. The (iDR regulators subsequently closed the Nord 2 reactor and planned also lo shut down Nord 3. Allhough lhe USSR

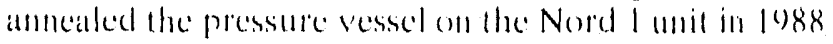
focorrect an carlier embrittement problem, West Cier. mall safely experts may ultimately recommend also

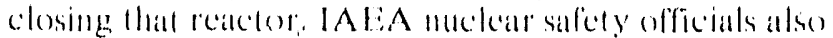
examined the Nord moclear plant and lound that its deficiencies were largely attribuled to a lew repetilive caluses, particulanly lailures in the I\& e equipment and poor reliability and manotenance of the salecty systems. The ageney plans forereruit an expent team fo advise planl persommel on correcting these problems.

Intra-ciemann nuclear saldely conperation has been im. peded to date becattse West (iermany and the losste have an aggerement hoshare a wide range of information

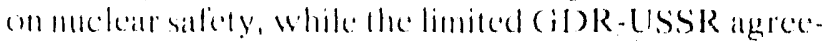

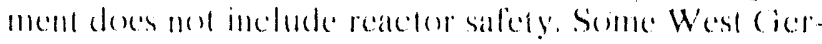
mats believe Hat the Sovieds restriceded heir distrihu-

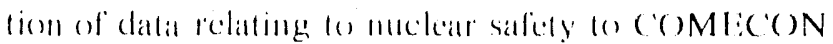

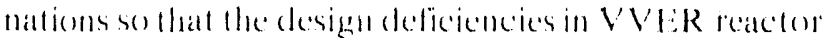

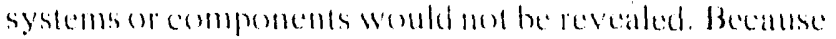
of the covolving political climale in bast (iermany, the USSR may agree lo include (iDR oflicials in West Cieman-Soviel exchanges of muclear salfely information that sould pertain to the (id)R's nuckeat program.

(iD)R olficials state thall the latest problems al the Nord plant will delay by up to o momlls the commeredial eperation of the Nord 5 unil for expensive back fitling of the Ide systems. The officials believe that design and construction of Soviet RMBK of VVIR reacents reflect a lower level of mockear lechmolegy compared to Western maclear recholology. They claim that the USSR's nuclear catablistument has latgely caused bast Cierman nuclear power problems becallse of imsulti. cient Sovice allention to improving safely standards,

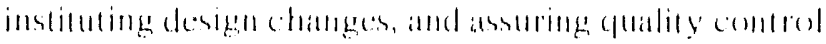
(on its reatome compuntents and malcrials.

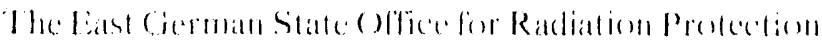

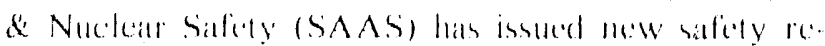

guirements for the linst fonr Nord medent renclers.

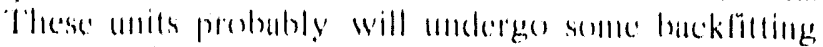

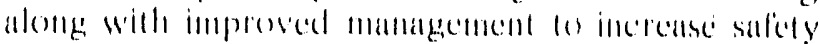

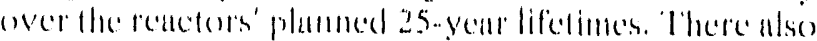

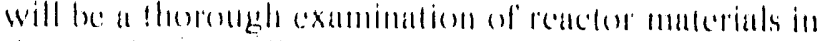

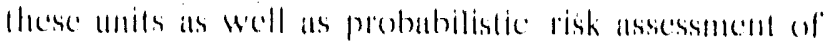

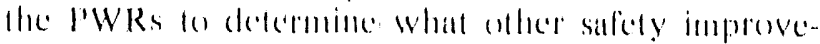
mentes should be mate.

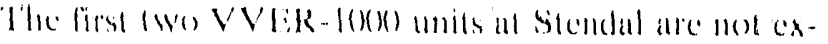

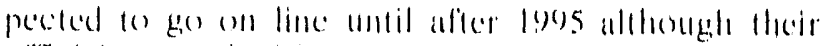

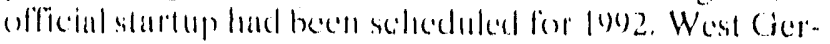

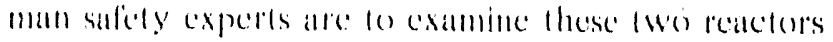
and recommend any neceled salidy improvements, some of which might be provided by westerm silpplicess.

The pilot 62. MWe Rlowinserg l'WR will be decommissioncel in loge. It has been used to lain operators

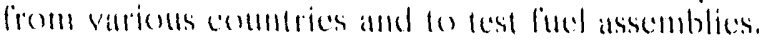

All enclgy commission was to be set up in endy log)

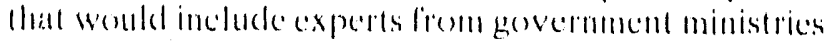
in both bast and West Cormany. The commonssion probably will meed several times cath year, and once of its lasks reportedly will be possible expansion of nuclear power gencration in the (iDR. Sentor liast cicrman officials hope to replace he connery's old lignite-fired plants wilh mones mosear power plants which they consider thedr chice siption as the (iD)'s lignite resciureces will be exhallsted wilhin 30 years. They would like to begin decommissioning some lignite-fired power plants in 190() and reduce the comntry's anmual comsumption of lignile by up fo lo() metric lons.

Three West (icoman utilities and the reactor vendor Siemens/ KWU may be involved in plans lo comstruct future nuclear reacters al stendal and I ceiperg. The last (icomans correnlly want their nuclear reacters to reflect molern Western lochonology and safety standards. If such projects are unclertaken, the cashorich West cieman utilities probably would largely finance reactor comslenction, will possible development loans from the federal govermment. The ulitities might stlpervise reactor comstruction and assist (iDR officials in obtaining nuclear steam supply systems from a reaceor vendore such as Sienuens.

The West (icrman govermment has approved a plan lo complede a 38 (o)-kilevelt transmission line between the lwo (icrmanies. 'The linst lege of this lime is ready to

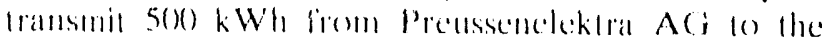

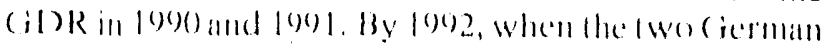

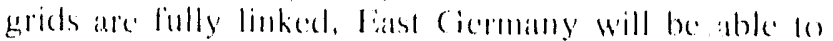

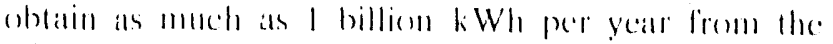
West (icomall gritul.

\section{Hungary}

Homgary operates four Sovied VVIBR-440 reacedors al

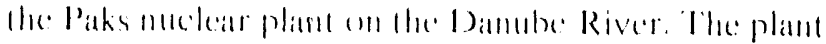

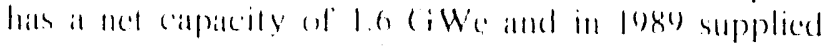




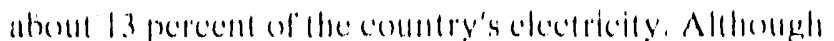
four other VVER-44(s) were origimally planmed for the

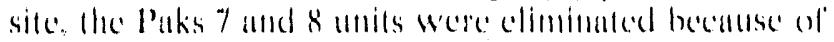

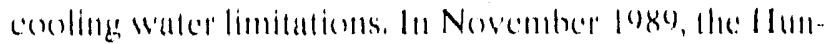

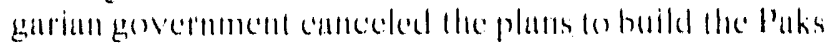

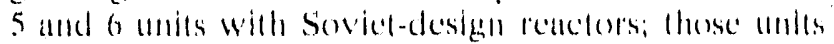
were intially scheduled lo he operational in the: mid-190)'s, the government ordered an end lo all presparatory worti on those units as it suspended its loge

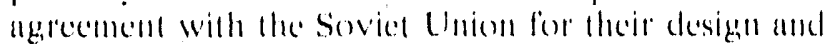
construction. Hungary clamed to have canceled these: plants because of lowe than expeceled growell in ell. cegy demand rather than concern over the Sovice. design reactors: however, neither the USSiR nor llungary could corrently finance enestruction of these ilinits.

Hungary's peak electrical demand currently is 6,523 MWe, will the centulley's powere plants providing 5,3.5() MWe and the USSR supplying $1,850 \mathrm{MWe}$ Much of the imported electricity may be mavailable in the listure because of Sovice power shortages, alihough 1, 10() MWo is monder lirm combacts.

The Hungariun blectricily Bourd (MVMT) hopes to obtain foreign capilal for comstruction of a majof new power station before $2(x)$. Soveral foredgn utilitios have indicated to the MVMl that they weruld be in-

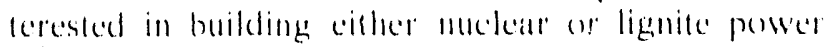
plants, with about halle ol the clectrical mulput exported

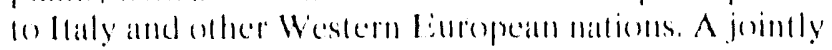
owned utility might be eslablished with llangaly holding 30 (o 35 perecent of the shates. It would pay about

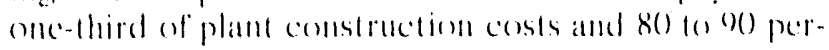
cent of operating costs, while its foreign partace would finance its contribulion through western capital markets. The project wendel rely on the Bos principle (build, (1perate, transfer), and is estimaled fo cost $\$ 2.6$ $\$ 3$ billion. To dalle, feasibility studies alle molerway anly with the fremeh utility fidti and the Camalian mility Ontarion Hydro.

Both the firench and Candedian offers include fuel supply for the muclear plant and recturn lo the foredgen country of the spent fied, but the latter presems a problem fecallese of the meed for transportation through therd

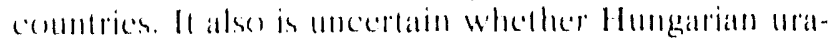

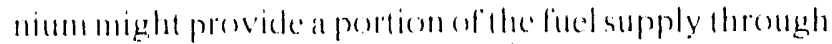
continued eperation of the Mecesek minc, a heavily

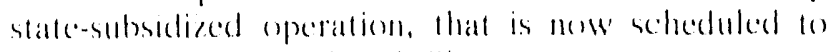
shut down in December for)(

()mario Hyder and MVMl have heen studying the feasibility of camadian aid in the comstruction of ome ar more (AND) muclear reacerse in Hungary. A prefeasihility study was completed in locecmber foge, and the fensibility study was on be completed by July

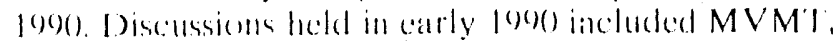

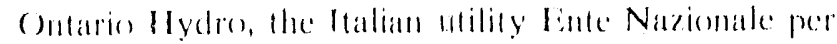
l'benergia bilettrica and the Canadian reacter vendor

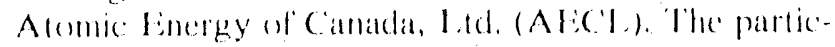
ipants considered allermate proposals for one or lwo

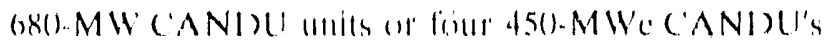

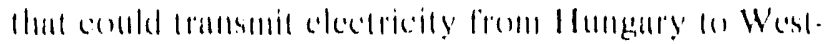

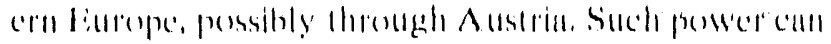

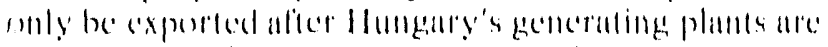

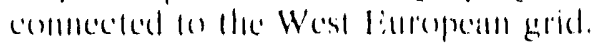

Lall" signed and agreement in early lon) for collaborale

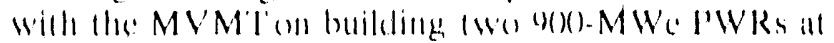

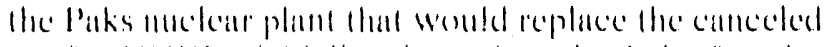
Sovide VVliks intially plantoded as the l'aks 5 and o units. Eidf would provide 70) perecent of the comstrucetion financing, a possible investment of $\$ 2$ hillion, that

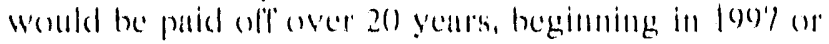

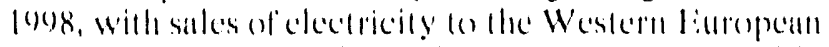

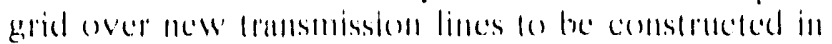
Austria. The lerench wendel supply the uranium for the: planl, late back the spent fiucl, alad supply operaling assistance lo MVMT for up to 5 years. Bechled, an American eompany, comlraseded with the Transedektro

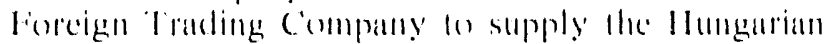

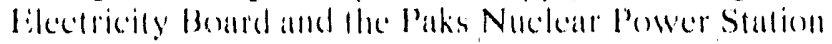

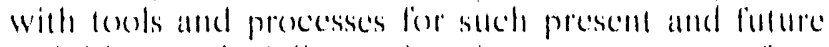
achivilies as scheduling and project manngems:nt of $110-$ chear powere operalions and radiondelive waste disposal.

\section{Poland}

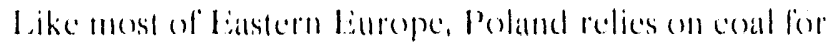
much of its electric powere generation, and demand for powere far exceceds supply. Becaluse of this situmion, the commly embaticed on an aggeressive muckeall course in the enrly geso's. The plan was to complete four

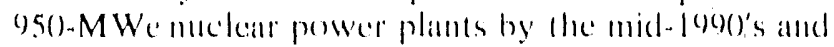

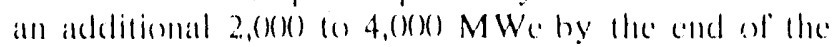
ceilliliry.

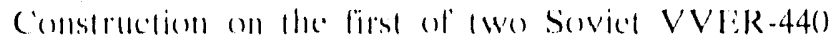
PWRs (Karmowiec 1 and 2 ) is aboul 40 pereent complete. Abent 70 percent of the reaceler components for the first unit have heen mamufactured and delivered to He sile. Comstruction on the Karnowiec 3 and 4 units never hegan and has been officially deferred. () December 27, 1980 line Polish Council of Ministers ordereda year-long hall to construction at the Zarnowice moclear sile near ( clansk. The government cited a "difliceult ecenomice situation" as the reasem for the interreptente presently no funding will be allocated for the

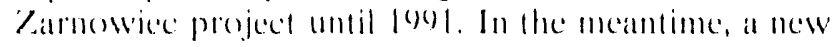
concegy policy is to be formulated and public opinion about muclear power surveyed.

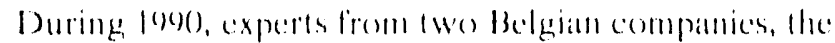
West Ciemant reaceder vender Siemens/kWU, and the IAl:A planned lo review the past comstrietion on the Carmowice medear plant and decide whelher and how

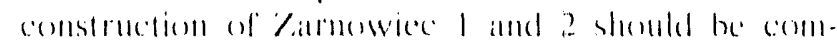

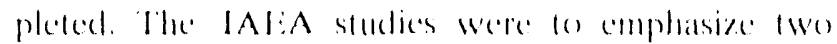

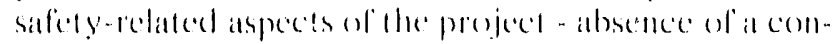
taimment and the pereceived sedismice rist of the site. If

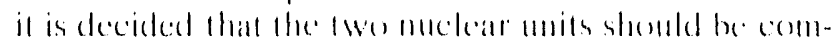
pleted, the Pelish nucleat cotahlishment wants the re- 


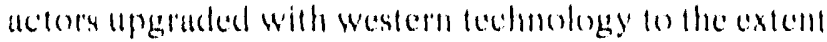
possible white still reduining the basice Soviet desigat.

\section{Romania}

Romania has no nuclear power plants in operation bul is building the cermavoda plant of live $625 . \mathrm{MWe}$ PHWRs that were ordered from Canada's AECL. Despite the presence of $\triangle \mathrm{ECL}$ personnel at the sitce construction of this nuclear plant has proceded slowly. However, the carelaker Romanian government signed contracts in cunly $190($ ) to obtain the AECL's aid in reorganizing construction at the plant. The Canadian work forece will be quadrupled, and Romania now plans to have Cermavoda 1 and 2 producing electricity by 1094: AECL officials claim that the first unit is less than 50 pereont eomplete, but possibly could be finished in 2 years with improved work conditions and better management at the plant site along with a renewal of Canadian credil ox expedite early delivery of additional components for the unit.

The former government had planned to build thirteen units with 12,00() MWe of nuclear generaling capacity, and ofticials of the caretaker govermment later made some policies on muckar energy. Alter the May eleclions, a new, extensive nuclear energy program can be established although envirommental groups could delay its implementation or caluse major changes therein. If the newly eleceded leaders view nuclear power as a continuing priority, and with Canada's further support. the remanning Cermaveda units might be completed by 1906. Moreover, another six-unit plant eoruld be eomstructed by the end of the logo's, posisibly in western Romania, and a third sile in the eastern region might be exploited by around 2010.

Durmg November 1989, the former Romanian gove ermment put inte cffeed an energy conservation law that sharply redeced the at valability of electricity for businesses and privale homes. Therefore, the suceesser gevernments have had fo face a large increase in the demand for power and expect lo purste the country's nuclear power program. They probahly will continte nuclear cooperation with their past partaces Camada and the USSR, hut possibly also engage in new ventures with Western nations such ats France or Span. However, Romania does not plan to import larnkey Soviet muclear plants, and has canceled the Moldavia VVER-1000 plant that was to be huilt with Sovicet assistance.

The caretaker government has chamed that only nuclear power can solve the country's huge energy prob. lems. A Romanian official has noted that the public is opposed on environmental grounde lo fossil-fired plants but mot to these using nuclear fineds. He stated that the conntry's concrgy sector must he completely reorganized to produce greater efficioncy. The energy ministry, which in being reorganized, has signed an agree. ment with fidt a molernize its cond-fired power plants, Romania's concrgy comsumption is likely to risc by up to 50 perecent in future yeurs, hale no new pland could go inde service for s years, l'owe imports from

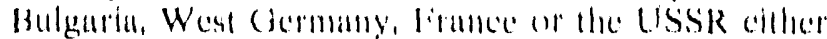
are scarce or reguire improved or new transmission lines. Romania's current lotal gencrating capacity is $17,0(x) \mathrm{MWC}$.

The former Alomic binergy Commission has been dissolved, and a new Energy Minister is responsible for the bountry's nuclear enceg program. A newly established National Commission for Nucleal Aclivities, Control aspires to promote international conperation in safeguards, physical protection sufety, guality assur-

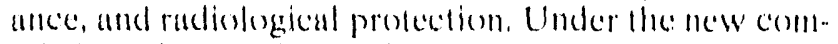
mission, the regulation, licensing and enforcement of maclear controls will be separated from the promotion of nuclear conergy development under the Ministry of Electrical Energy and other research activities of the Institule of Atomic Encrgy.

\section{Countries With Centrally Planned Economies (CPE)}

\section{The People's Republic of China}

The Peoples Republic of China's muclear policy has been largely unaffected by the events in Lastern Eurepe; however, the events at Thananmen Squate in 1989 and a worse than expected balance of payment problem have slowed international cooperattion. Although it is mote difficult now lo assess the future of China's meclear program, the conmtry's need for clectricity eontinues fo drive its aggressive program for nuclear power development.

In the early fo80's, china plamened live 2,(0)()-MWe muclear power plants along its populous eastern coast hut, because of a shorlage of funds and insufficient fabrication capacity, sielved its plans for all but the three units now being built. Chima now appears committed fo the develepment af four $6(0)(0)-101,()(0)-M W E$ nuclear units hy $20(x)$. These projects include the (Sinshan 1. the Rwe french-designed PWRs at Daya Bay, another project propesed lor Jiangsu province in the cast, and a plant in mortheastern I ianming provinec.

The coumley's first muclear mont, Qmohan 1, is more than 80 pereent complese; it is mostly of domestic design and is being comstructed by chincse firms. Siemens/KWO of the lecteral Republic of cicrmany is providinge comstruction mantagement services. () nly atew key components are foreign, among them the reacter vessed from Japan and the main pumps from West (icomany. ()inshan I should genterate its lirst elece. tricity by late lo(t) 
Chima's second nuclear power project is loculed at the Gunngdong site near Duyu Bay, The project comsists of Iwo $9(0)-\mathrm{MWe}$ units that were scheduled to operate in 1902 and 1993. Work was hulted, however, in late 1987 and resumed in endy 1988 after correction of design deliciencles. The unils, supplied by Framalome, are a jolnt venture by llue Guangdong Nuclear Investment Company (75 percent) and the Hong Kong Nuclear lnvestment Company (25 perecul). China Power and Light (the utility serving Hong Kong) will lake 70 pereent of the power generated by the anits.

The Bedjing Instilute of Nuclear Englneering was awarded the design contract for the second phase of the Qinshan 2 and $36(0)-M W$ e PWR's that ure cxpected fo be completed later this year. The Siements Framatome joint venture, Nuclear Power International, has recendly reconfirmed its offer to help build the $6(0)-M W e$ units, but the issue of price remains uncertain.

In 1988 China announced plans fo construct andelen units on Hainan Island, located at the extreme southern end of the mainland, and in lujian province, Hainan has been declared a "special ecentomic zone," similar (1) what Hong Kong will become when it reverts 10 Chinese control in lo97. The development program for Hainan calls for electrical generating capacity, now al about $200 \mathrm{MWe}$ to incroase tenfold. Power plants of several types would be built to satisly the expected growth; however, only one is currently slated to be nuclear.

The Fujian project is at an earlier stage of eomsidenation. Il is located on the soulheastern coust belween Shanghai and Hong Kong, an alrea decmed likely Io experience considerable economic growth in the near future. Onler potential sites for additional plants are near the Daya Bay muclear plant and in the 'Taishan Districel.

In November 1989, China agreed to supply a 30)-MW6 PWR o l'akistan. A formal agreement fo hegin construction on the Chashma unit in the Mianwali District of northern P'unjub is expected shorly, according to the Chatrman of the Pakistan Atomic Energy Commission. The Pakistan reactor will be an improved version of the Qinshan unit, and its construction would involve bilateral eosperation with China supplying most of the technology and expertise as well as fuel and spare parts. In addition, China would supply Pakistan with its own indigenous enriched uranium supplies. The plant would be operalled under IAEA safeguards and is sededuled to be completed by 1906.

\section{Cuba}

The Cuban Covernment is now huidding its lits noclear power pilant, He Iwo-unit 'Juragina, localted al Cienfuegos. In 1986, Cuban leader fïlel Castro disclosed his mation's intention to construet a third munt
In censtern Cuba once the Jurugua plant is completed. However, the lwin 408-MWe l'WR station, suppliced by the Soviet Union, has been delayed due lo the ad. ditlon of new sufety fentures. Lnit i is llow scheduled for connection to the gerid in log2. Cubu also is establishing a nuclear regulatory infrastructules.

\section{North Korea}

In 1985, the Peoples' Democratic Republic of Koren signed the Nuclear Nom-l'roliferation T'reaty (NI'T') us a prerecyutsile to receiving 1 planned four-unit nuclear power plant lrom the Soviet Union. Although the So. viel Union announced that it would help Notiln Korea to construce the lour PWRs belween 1980 and 190(), no construclion has ever begui, In a report submitled (o) the National Assembly for raview by the govern. ment's National Unification Bourd, North Kotea had yet to select a site for the four Soviet VVERs which would have a combined capracity of $1,760 \mathrm{MWe}$. The delay in the nucleat project could be attributed to the country's deterioraling finnocinl situation.

\section{Soviet Union}

The IISSR comnected two 950-MWe l'WR to the grid in 1989 . South Ukraine 3 and Zaporozhe 5. It eurrently las 4.3 operable nuclear generating units with 34.2 MWe of capacity; another 5.3 units with 55.5 CWe are in the construction pipeline. The development of nuclear power is considered very important in the Sovied energy picture since it is difficull and expensive to bring energy from the conntry's far northern and eastcrn regions fo the many consumers in the European Soviet region. Also, the power industry reportedly ac:counts for about once-quarter of Sovice industrial pollution. However, some cilizens and public oflicials have opposed nuclear power projects in ererain areas of the USSR because of safety considerations,

The: USSR plans fo replace the steam generators on all of its VVER - $0(0)$ s that have operated for more than $40,(0)(0)$ hours; it will backfit the nuclear units with shorter periods of operation. Investigations have determined that the steam generators suffer from both peror design and defective manufacturing. The generalors have already been replaced on hree reactors, while those on eleven other nuclear units will be replaced in coming years. Generators on the VVER-440s are arranged differently than on the VVER-10(0)s and do not need to be replaced.

The Soviets have developed a program to anneal pressure vessels on the VVIRs that have heen huilt in the USSR and supplied to Comecon countries in eastern Earope. Western safely experts have been skeptical of the program's credibility since the soviets had provided litte information about it; however, the IISSR was expected to provide considerable dala aboul the

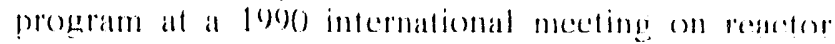




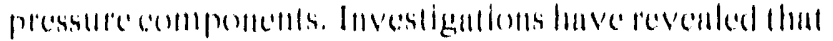

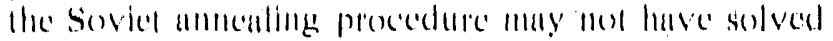

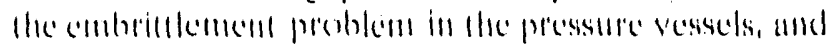
possibly neceds to be impirened.

The ISSR permancmtly chosed down its Boloyarik 2

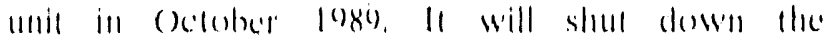

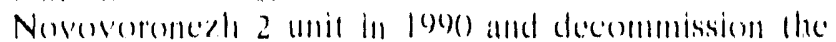

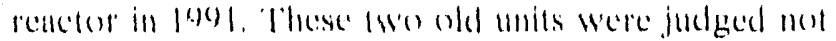

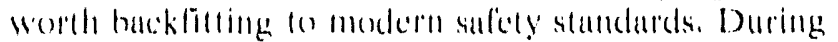

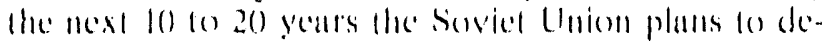

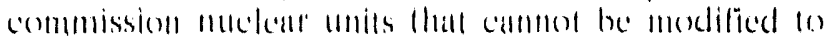

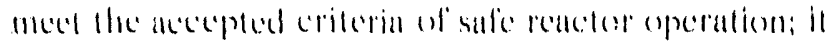

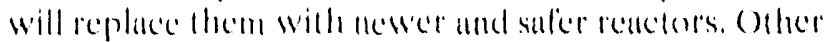
nuckear powere plants will be moditiced lo mod the

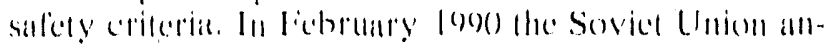
nomiced a delay in the commissioning of the Rostov I 950 MWe l'WR near Volgodonsk so that an envirummental study coukd be undertakin.

The Armentan republis has sulfered encogy shordagess

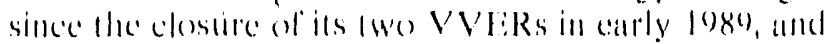
new nuclear units are being comsidered, presumably al siles more distant from earthemate prome areas. Also in 1089, the USSR halled construction of the Atkash

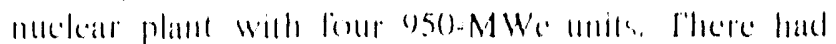

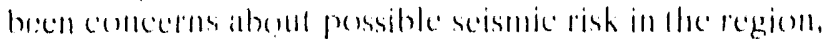

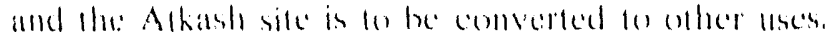

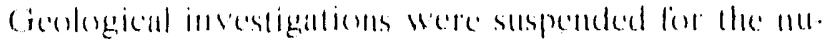

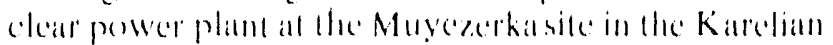

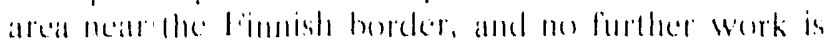

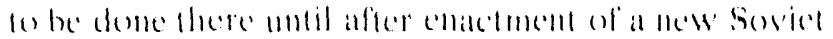
law an muclearr regulation.

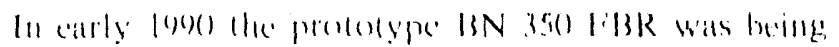
repatered bul hats recendy been ased only for water

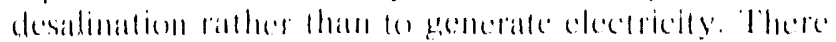

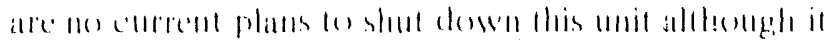

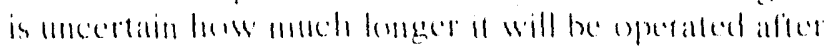
reparim atre completed.

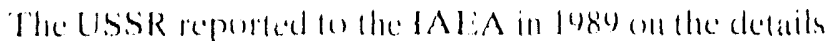
of a 1957 accident all llae Kyshtym military nuclear

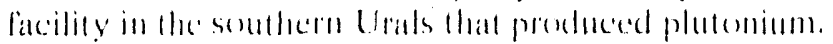
failute of a conting system in a tank containing highth. level waste resulted in a chemical explosion and a re-

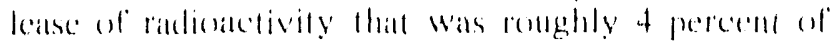

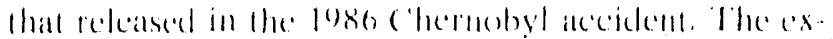

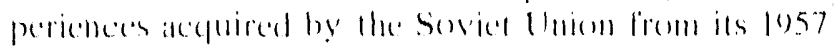

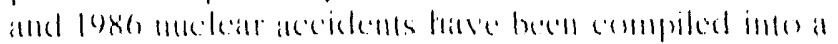
suide for use by Hee covilian and militaly meleat industress in the disSR. The guide provides planninge and

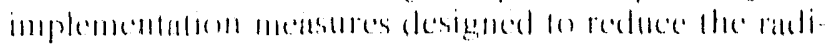

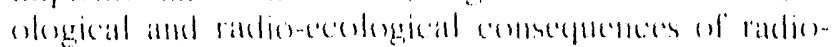

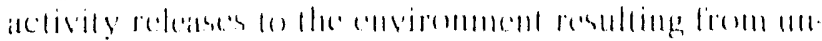

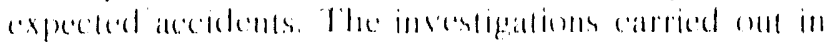

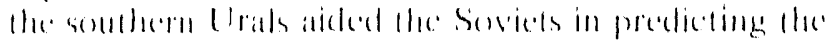

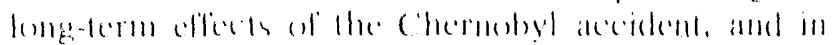

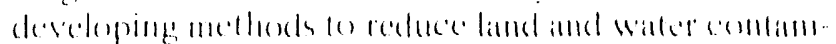

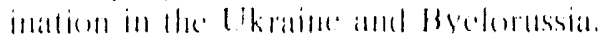

A feasibility repond in expected lo be compleded int

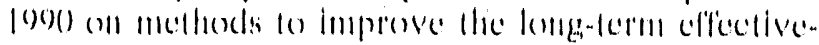

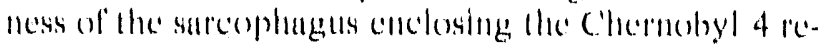

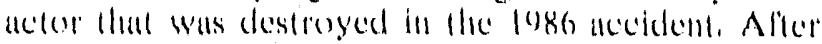
detalled plamming is donce, the werk mighe statt by

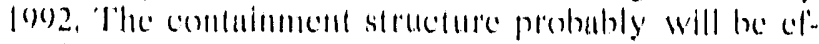
fective for al least 30 years allhomgh inlermal compronents may need adelitionul reinforecoment. A processing plant is planned lo condition and packuge the latge announts of comtamimated material that have aceuma-

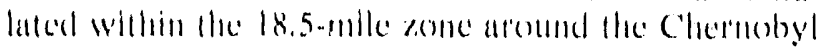
pliılil.

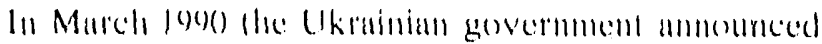

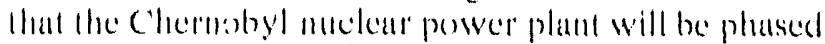

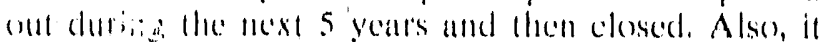
does mo wall ally more nuclear plants within its bor. ders, The central Sovied govermment has exerted final conten over such decisions in the past but, as power is shiffed gradmally o the republics, it may allow the Uk ramian decision lo prevail. While some Lkminiansi believe that the three remaining Chermobyl reactors are dangerous, anthorities in Moscow and lige Ukraine

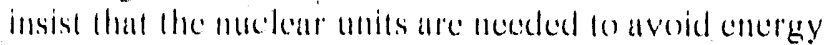
shortages in the region as well as to provide power for bastern Earope. The Ukrainian republice colrently has

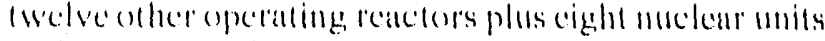

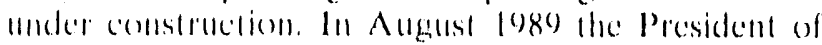

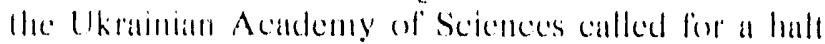
lo all current comstracticon of nuclear power plants in the republic molit newe, sater reactors can be designed and built. He also sillggested He developmente of allermallive collergy' solloress.

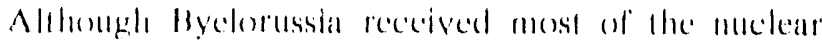

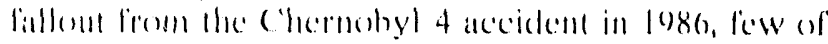

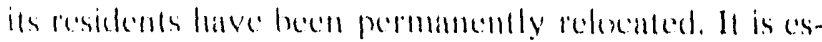
limaled that + million people are living on comtaminated

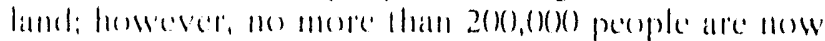
schedeluled for altimale resedtlement hy logs in clean areas. There also will be some resedtlement of people living in certain portions of the L Ih rainian and Russian

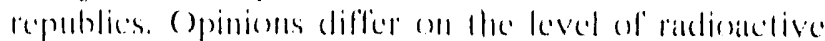
contamination in the food and water supplies of Byelorussia, the Ukraine and the Russian republic, and

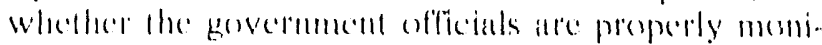
foring such combamination. The IAl:A anmonneed in

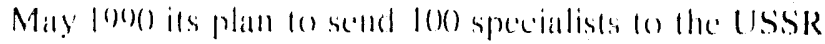

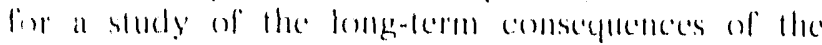

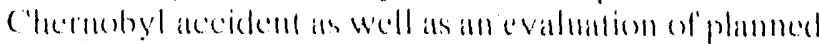

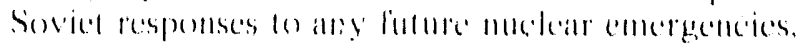

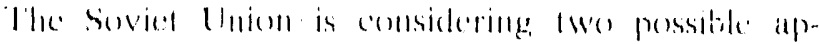

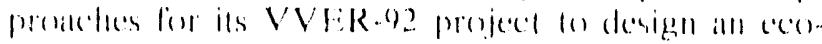
momic PWR that imeorperates patsively salfe feallures.

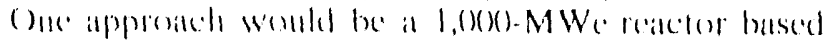

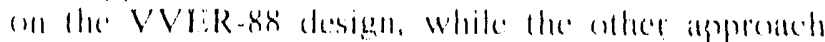

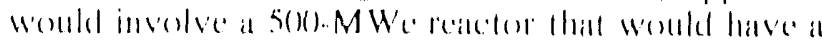

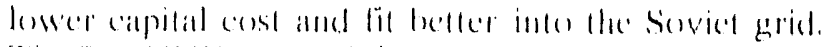

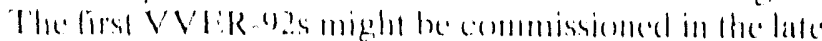
l(1)(5)'s 
The Soviet Union has reorganized its nuclene burenterasey. 'The nuclear committec has been merged with the commiltee supervishng general industrial safely 10 become a regulatery body than is more concertied with ntuclear plant licensing than with superviston of operating nucleur unils. Under consideration is a fourstage precesss, ranging firom licenseses for nuclear plant construction siles fo those fer anctual construction and operation up through licenses for decommissionngh.

In 1989 and enty 1990 the USSR signed nuelear com operation agreements or contracts with vartious foretgin companies and governments. All agreement with the U.S. Department of Energy involves the assistance of the U.S Institule of Nuclear P'ower Operations in running a new program to improve the operation and mianagement of Soviel commerciul nuclear power reactors: the program will initially focus on the first-generation Sovide PWRs at the Novovoronezh plant. All agreement between the USSR and Edti, the lifench utility,

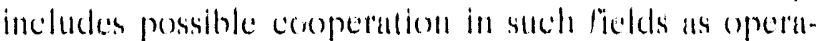
tional safety; design, comstruetion and decommissioning of muclear facilities: and established or improvecl procedures to recover from nuclear power plant alecidents. An agreement between the Canadian and Soviet governments relates to cooperation on ficilities for fuel fabrication, uranium isotope separation, and pro. duction of heavy water as well as certain technology transfers pertaining to nuclear power generation in both eountries. An agreement between the Soviet Union and Nuclear l'ower International, a partnership of West German and French reacter vendors, provides for enoperation in the development of future PWRs in the USSR, possibly including assistance in the design and development of the VVER-(9).

The Soviet Union hus signed contracts with Siemens/ KWU of West Germany for certain services and prodeIlces, including the following: (1) scismic antalyses of VVER-10(0)s under construction in the USSR: (2) de:livery of control systems during 100()-190) (0) bring operating Soviet PWRs up to western standards; and (3) supplying rencter monitoring systems for Sovicet PWRS.

The USSR also has discussed possible procurement or sale of nuclear reactors with other foreign mations. which include lhe following:

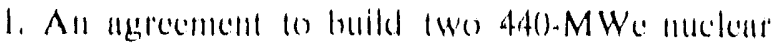
units in lrun and assist in completing that contulIry's lwo 1,16)om MWe Bushehr units. Irun expecied on begin exporting malural gas lo the USSR in April loye) in partial exchangere for the Sovicet aid.

2. Neguliutlons will India uboul supplying Sovien VVER-88s for lloe Kudunkulann nuclear project in which these PWRs would be tullored lo lndiun entid recpuirements and anticipated operating prom ceclures.

3. Discussions willh Chinu (In the sale of a 2,(x)()-MWe nlledear plant that would be constructed near Jiangsu in the province of l.ianoming.

4. Continning negoriations with a West cierman contsontium for foint design and construction of an 8()-MWe H'T(BR at Dimitrovgrnd, USSR.

5. Plans to supply nuclear fechnology to North Kor rea ufter 1994 at a site yet fo be selected.

Over a number of yeurs the Sovied Union designed both light water reactors (VVLRs) and light water cooled, gruphite-modersted reactors (RMBKs) for the USSR but supplied only VVERs Io its COMECON partners. However, Hose Eastern European comntries are now evell more cencerened about the safely and reliability of Sovied muclear reactors, and it is likely that many of the nuclear units in their construction pipelines will be huill eillew with redesigned soviel reactors or entirety with western technology.

In June 1989, a Sovict official annononeed that the coumtry's latest power development program calls for under $10(0,0)(0)$ megawalts of mucleur generating capacity by 2(X)(), only (wo-thirds of the minimum goul set in earlier long-term plans. Fulure nuclear plants are to be buils in remole areas with the latest reactor lechonology. The draft of the new program was on be released for public debate. Although the program emphasizes the VVERs, it also includes reatedors for districe henting and nuclear cogencration. By 2010 maclear power might supply about 25 pereent of the total energy in the Sovied Union 
Appendix A

Federal Regions 


\section{Federal Regions}

Figure A1. Federal Reglons

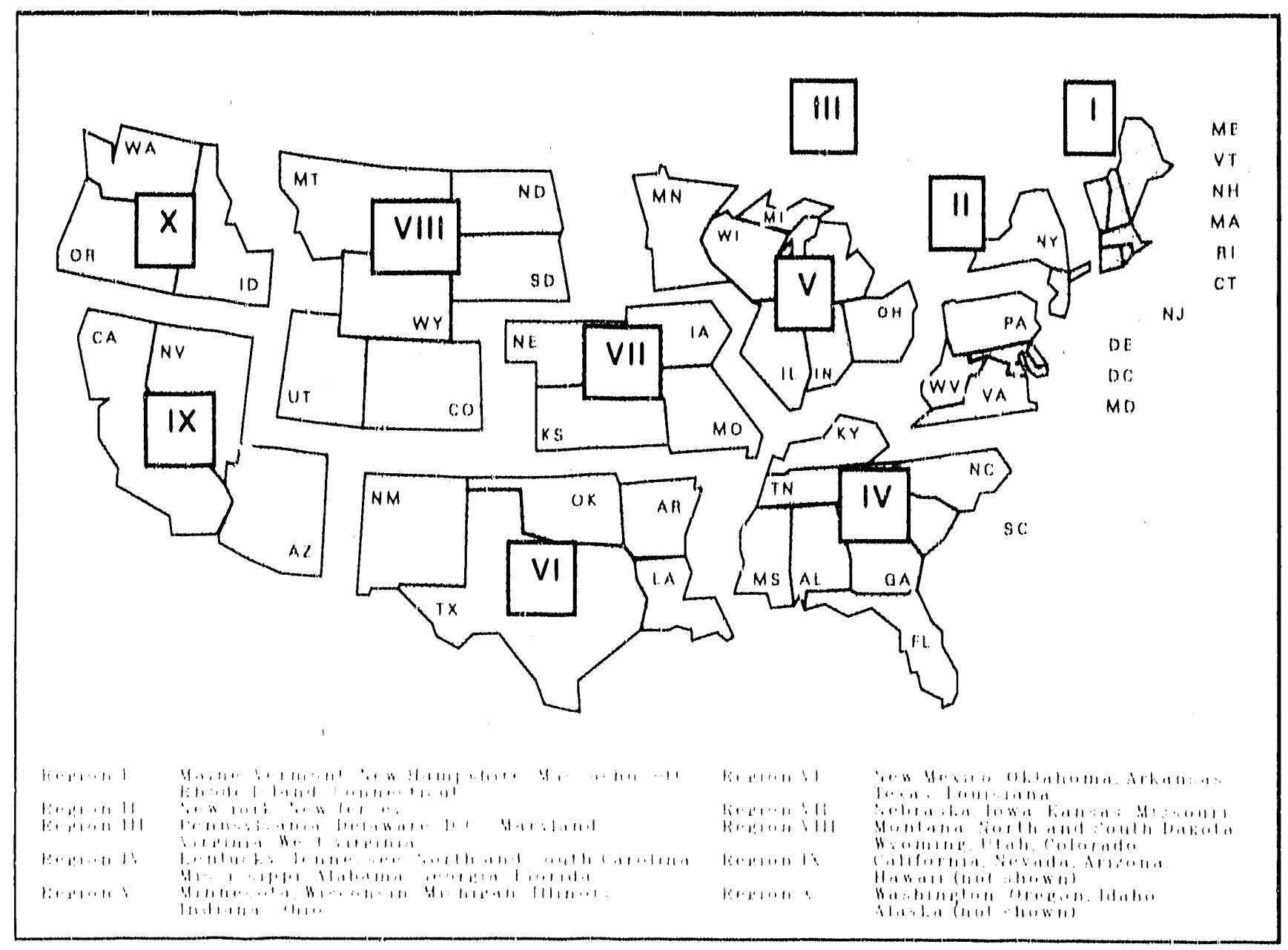


Appendix B

Notes on

Projection

Methodology 


\section{Appendix B}

\section{Notes on Projection Methodology}

\section{Reactor Construction Pipeline Methodology}

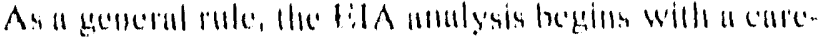

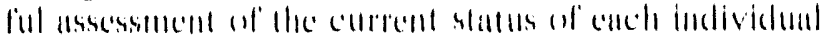

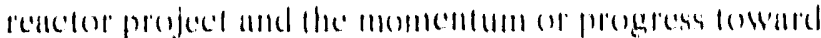

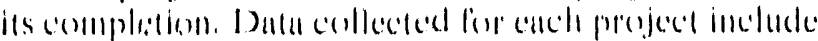

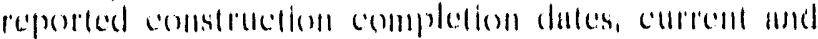

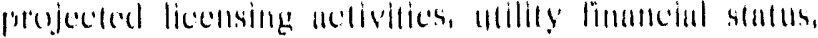

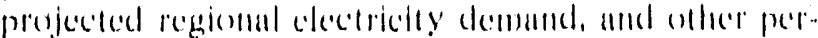

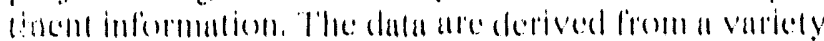

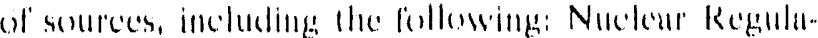
lory ('ommission (NRC') construction and licensing reports: Form l:1 A-254, "Sc:mlanmmul Report on Stulum

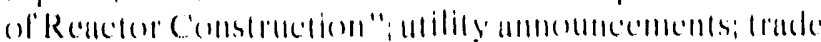
jourmals; newspaper reports; and conversutions will

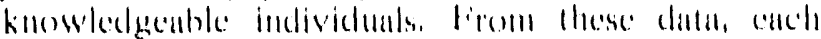
project is cevaluated as 10 its position in the overall

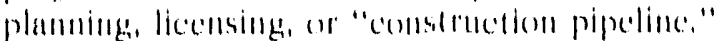

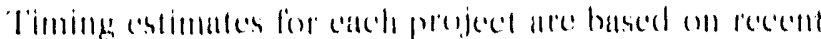

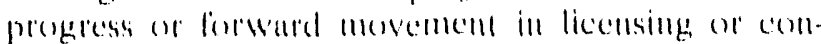

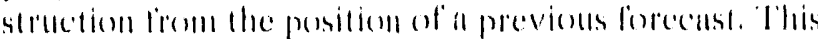
includes such indicallors als changess in perecent of contstruction completed, anticipated or completed licensing actions, and unnounced delay's. Average comstrmetion and lierensing times derived from ann monlysis of form bis-2.54 data show that nuclear units that began commercial operation in 1971 16 107.3 were constrieled in 4 16) 6 yenrs. By the micl-197()s, 1974 dorough 1077, the average construetion time had inceased 107 to 8

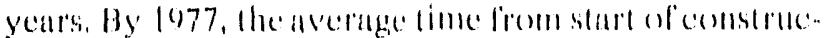

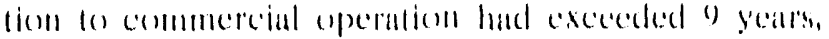
and by loge the average time had renched nearly 12

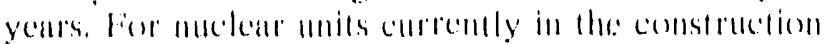

pipeliste, alectrite atilities estimate the avernge time

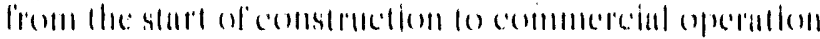

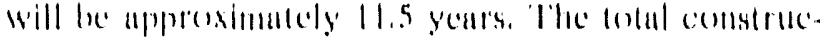

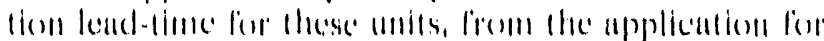

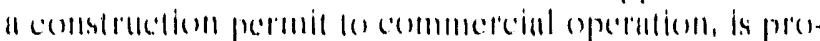

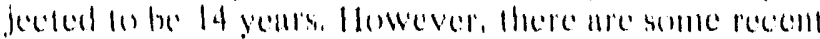

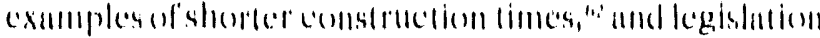

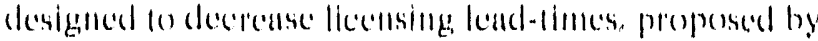

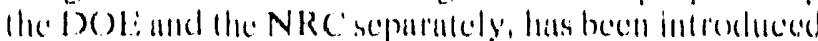
in Congremis.

lable 131 presents stutisties on the expresed avernge

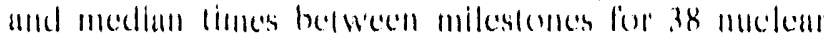

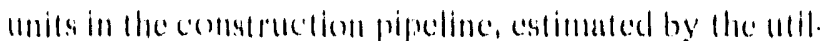

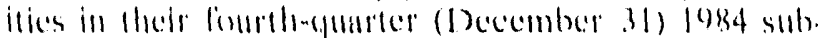

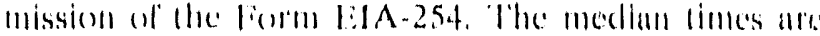
reported beceatuse for some of the milestentes the wide

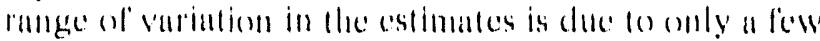
units, for purposeses of estimating operable capacity, it is assumed that a wnit becomes aperable approximately halliway between the date of lirst eriticenlity and the commercial operation date.

Given the kencl-limes shown in Thble Hh, other factors relative (o) millity planning, scheduling, and construce lion are introduced into the projections. For exumples

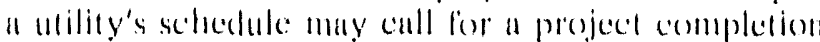
date which is later thas that indicated by the histerical data anulysis. (litities with multiple units asually have

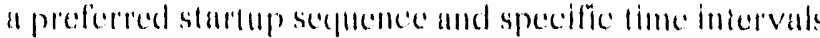
for plasing in later units. Where the historical dala amalysis may indicate a longere construetion time hau mility plans fore earlier undts, subseyuent units may also be delayed aceording to the mility segueneing sehed-

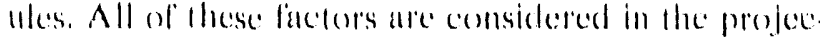
tions for the lower Reforence and Ipper Reference cilse's. 
Table B1. Average Estimated Times Between Milestones for U.S. Nuclear Units in the Construction Pipeline in 1984

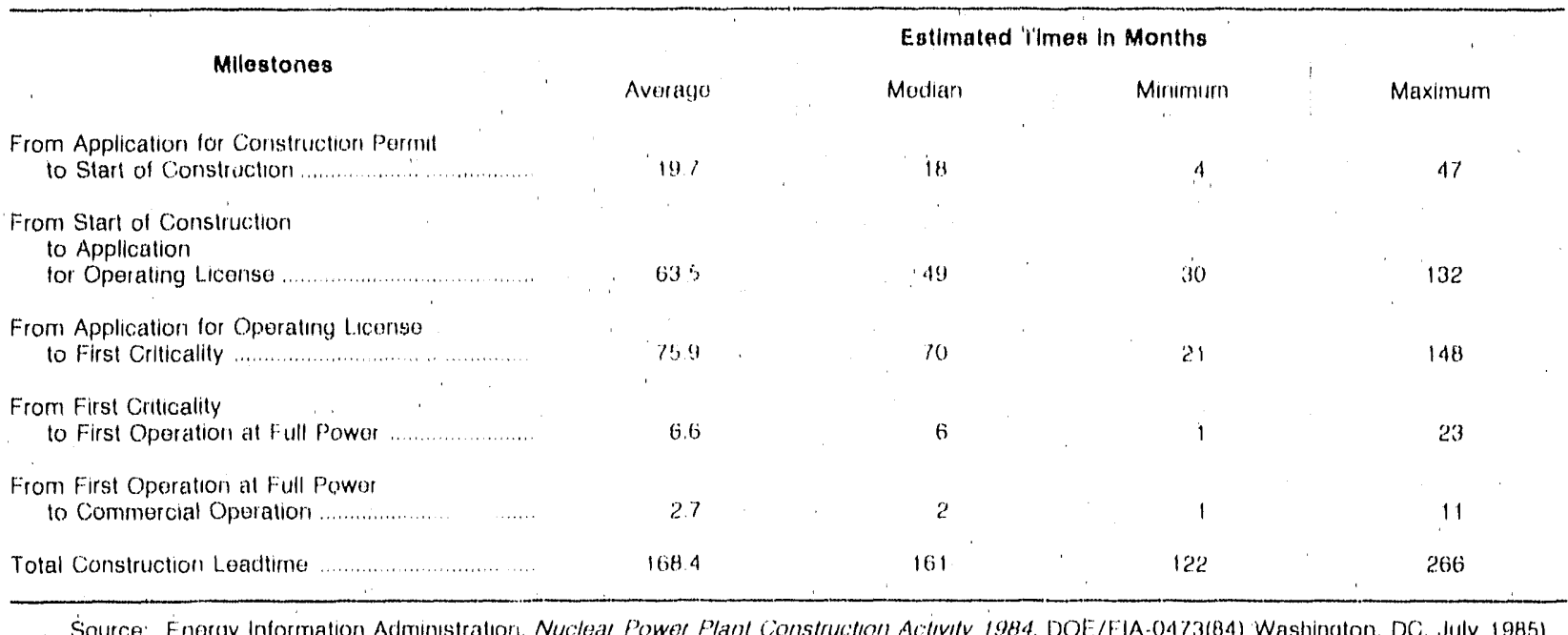

\section{World Integrated Nuclear Evaluation System (WINES)}

The World Integated Nuclear Evaluation System (WINES) has been developed io project long-term nuclear generating capacity worldwide."1 in as Energy projections can be made for each of 125 countries and can be aggregated by regions or by economic and political groupings. WINES is a relatively simplistic model, utilizing a "top-down" aggregated approach. The model is of a partial equilibrium nature, in that there is no feedback from the energy sector to the rest of the economy, such as is typically found in more detailed microeconomic models. The primary objective of the model is to produce projections of longrange world energy, electrical generation, and nuclear capacity.

The driving variables of the WINES model are economic growth and growth in the price of energy. Labor-age population and participation rates, as well as labor productivity, provide the basis for projecting economic growth, which is then combined with the price of aggregate energy fo form a demand function ' (with constant price and income elasticities) for delivered energy. The growth rate for delivered energy is combined with a beginning-year initial value of delivered energy to develop a projection of delivered energy in the long term.

The electrica! share of delivered energy and the nuclear share of electricity are derived using market penetration (logistic) models, which adjust the respective shares from current values to anticipated asymptotic values over time. Electrical generation for each year of the projection period is derived by applying the electrical share to delivered energy for that year. In the same manner, nuclear generation is derived by applying the nuclear share to the electrical generation for each year. Nuclear capacity is calculated from nuclear generation, assuming that sufficient capacity will be constructed to satisfy the generation requirement, utilizing an assumed average capacity factor. The model is specified in terms of growth rates up to the point at which absolute delivered energy demand is derived. From that point on, absolute amounts are calculated (i.e., electricity, nuclear generation, and nuclear capacity). A flow chart describing the WINES methodology is shown in Figure B1.

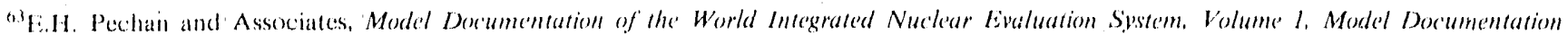
(Washington, $\mathrm{X}$ : June 1985).

${ }^{14}$ E.H. Pechan and Associates, Model Documentation of the World Integrated Nuclear Evaluation System. Volume 2, Model Description (Wasthingtom, $D($, June 1985$)$.

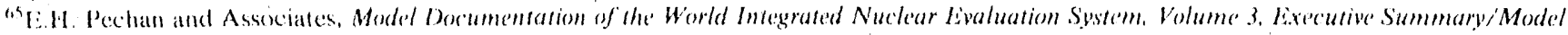
Abstruct (Washingteis, D) , June 1985)
} 
Figure B1. Flow Chart for the WINES Methodology

(Population Data)

Labor-Age Population
Growth Rate

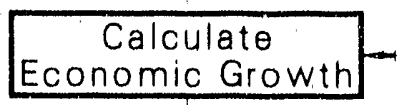

(Energy Price

Growth Ratel

(Delivered Energy

in Base Years)

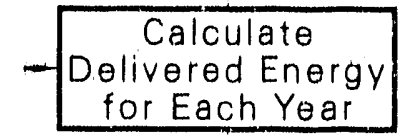

for Each Year
(Labor Productivity Growth Rate, Labor Force Participation Fraction Growth Rate)

(Price and Income Elasticities)

of Delivered Energy

Apply
Electrical Share
to Derive
Electric Generation

Calculate

Nuclear Share

of Electricity

$$
\text { Apply }
$$

Nuclear Share

to Derive

Nuclear Generation

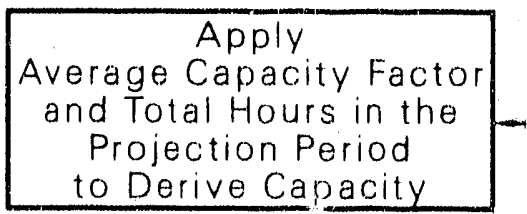

(Capacity Factor)

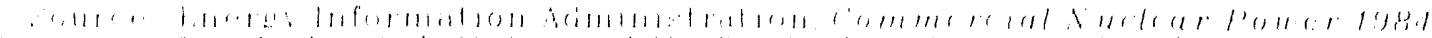

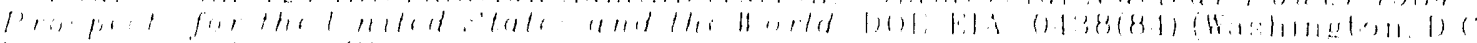

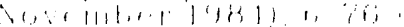


Although WINES is conceptually simple, a number of vartables and parameter's are required to generate nuclear capacity projections. One key data set, labor-age population growth rates, is derived from the World Bank population projections by evaluating the change in the population between the ages of 15 and 60 years (inclusive) for each country over 5-year intervals.to Another major source of data for the OECD countries and several others is the OECD survey conducted in 1980 and undated in 1983, 1984, and 1985. ${ }^{67}$ ox For ench country, an estimate is provided for 1980 and for 5 year intervals to $200(0)$ (for most countries) for the following variables:

- Total primary energy requirements

- Electricity generation requirements

- Nuclear generation requirenents

- Nuclear capacity.

The survey responses in most cases provide the baseyear values for these variables and those derived liom them (e.g., delivered energy, electricity share, nuclear share). If values of the energy data for individual years are not reported in the OECD survey, these are interpolated linearly, where possible, from previous and subsecpuent periods. The survey is supplemented in several cases by the "pipeline" analysis method described in this report.

The energy data used in the WINES model ate decu-

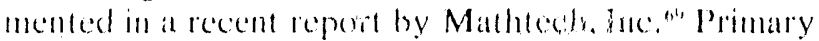

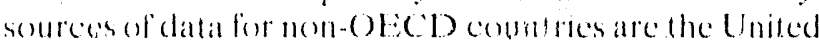
Nattions lecorlook (1982) and the Wortd Bank 1982 World levelopment Report. For several non-OSE(D) countrics that are expected soon to initiate nuclear pro. grams. (Ofic s) survey datat are used in place of the Uniled Nations statisties. Lor some comntries, telal pri. mary energy values are deried from the central an-

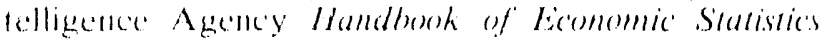
(1983). All other paranneters lake on assumed values. based upon other empirical wom or ate combinations of atsimmed and survey values.

\section{Mathematical Description}

The model is specified in terms of growth rates up to the point at which absolute delivered energy demand is derived. Frem that point on, absolute amounts are calculated (i.e. clectricity, melear generation, and nuclear capacity).

\section{GNP Growth}

Economic theory suggests that economic activity, in the long sun, is primarily inflictened by the size and productivity of the labor force. Labor force size is determined by the labor-age population (the potential labor forces and labor participation rates. GDP growth (GNP is used for the United States; see the Glossary for a definition of these terms) is specilied as the combination of the growth rates of these three factors:

$$
g_{1} \cdots L A P+P A R T+P R O D, \text {, (1) }
$$

where:

$g_{t}$ is the GDP growth rate in year $t$ of the forecast period,

$L A P$ is the labor-age population growth rate,

$P A R T$ is the labor force participation growth rate, and

$P R O D$ is the labor productivity growth rate.

\section{Delivered Energy}

The growth in delivered energy is then ealculated using an energy demand growth function:

$$
d_{1}=\gamma \cdot g_{1}+\pi \cdot p_{t}
$$

where:

$d_{1}$ is the delivered encegy growth rille,

$\gamma$ is the ineome clasticity.

$\pi$ is the price elasticity, and

$p_{t}$ is the grow th rate for real aggeregate energy prices.

The price and income elasticities are discrete functions of per capita GDP. That is, they change over time whemever cousulries move from low lo micklle or middle to high income coonomices aceording to World Bank categeries. Energy demand is generally considered to be more price clastic and less income elastic for higher income countries. The shift in elasticities reflects the commonly accepted premise that high incomo countries have greater opportunities for adjustments of encergy consumption than do lower income countries.

The actual level of delivered energ: $\left(D_{1}\right)$ for each year is derived by applying this calculated growth rate to the base yeall and cach subsecguent yeart:

$$
D_{1} \cdots D_{1,1}\left(1+d_{1}\right)
$$

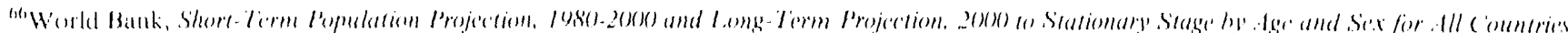

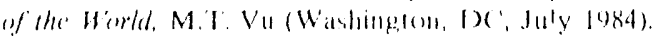

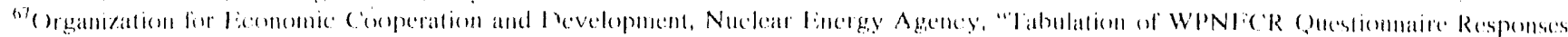

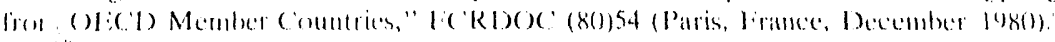

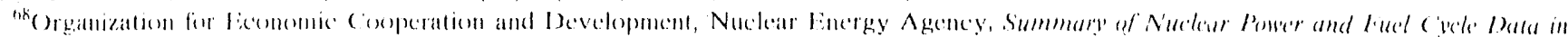

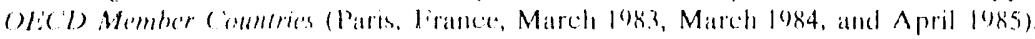

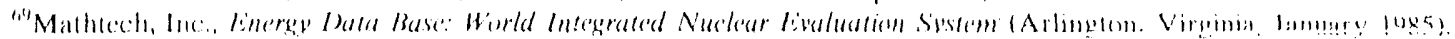




\section{Electrical Share}

The electrical share of delivered energy is derived using a logistic curve penetration model:

$$
f_{1}^{v}=\frac{f^{t}}{1+c^{-(a+\beta 1)}} \text {. }
$$

where:

$f_{t}:$ is the electrical share in year $t$,

$f_{x}^{t:}$ is the clectrical share asymptotic limit,

$\alpha$ and $\beta$ are the parameters of the logistic curve,

$a=\ln \left[\int_{0}^{\prime:} /\left(f^{t:}-f(t)\right]\right.$,

$\beta=(1 / h) \cdot \ln \left[\left(f_{t}^{t}+f_{(j)}^{t}\right) / f_{0}^{t}\right]$,

$f_{10}$ is the base year electrical share, and

$h$ is the halving factor for the logistic curve.

The total electricity generation for each year $\left(E_{i}\right)$ is calculated by applying this share to total delivered encrgy:

$$
E, f_{i}: D
$$

\section{Nuclear Share of Electrical Energy}

The nuclear share of electrical generation is also derived using a logistic penetration function:

$$
f_{i}^{N}=\frac{f_{\infty}^{N}}{1+e^{-(\tau+\mu l)}}
$$

where:

$f_{t}^{N}$ is the nuclear share of electricity in year $t$,

$f_{0 .}^{N}$ is the asymptotic nuclear share,

$T$ and $\mu$ are the logistic curve parameters,

$$
\begin{aligned}
& \tau=\ln \left[f_{(0)}^{N} /\left(f_{\infty}^{N}-f_{0}^{N}\right)\right], \text { and } \\
& \mu=(1 / h) \cdot \ln \left[\left(f_{\infty}^{N}+f_{(0)}^{N}\right) / f_{0}^{N}\right] .
\end{aligned}
$$

Again, nuclear generation $\left(N_{t}\right)$ is calculated by applying the nuclear share to total electricity for each year:

$$
N_{1} \cdot f_{1}^{N} \cdot E_{t}
$$

Finally, nuclear generating capacity is calculated using an average capacity factor $(\mathrm{C} F)$ :

$$
C_{1} \cdots N_{t} /(C \% \cdot 36.5 \cdot 24) \text {. }
$$


Appendix C

U.S. Nuclear

Generating Units

Operable as of

December 31,

1989 


\section{U.S. Nuclear Generating Units Operable as of Decerabor 31, 1989}

Table C1. Roster of U.S. Nuclear Generating Units Operable as of December 31, 1989, by Federal Region and State

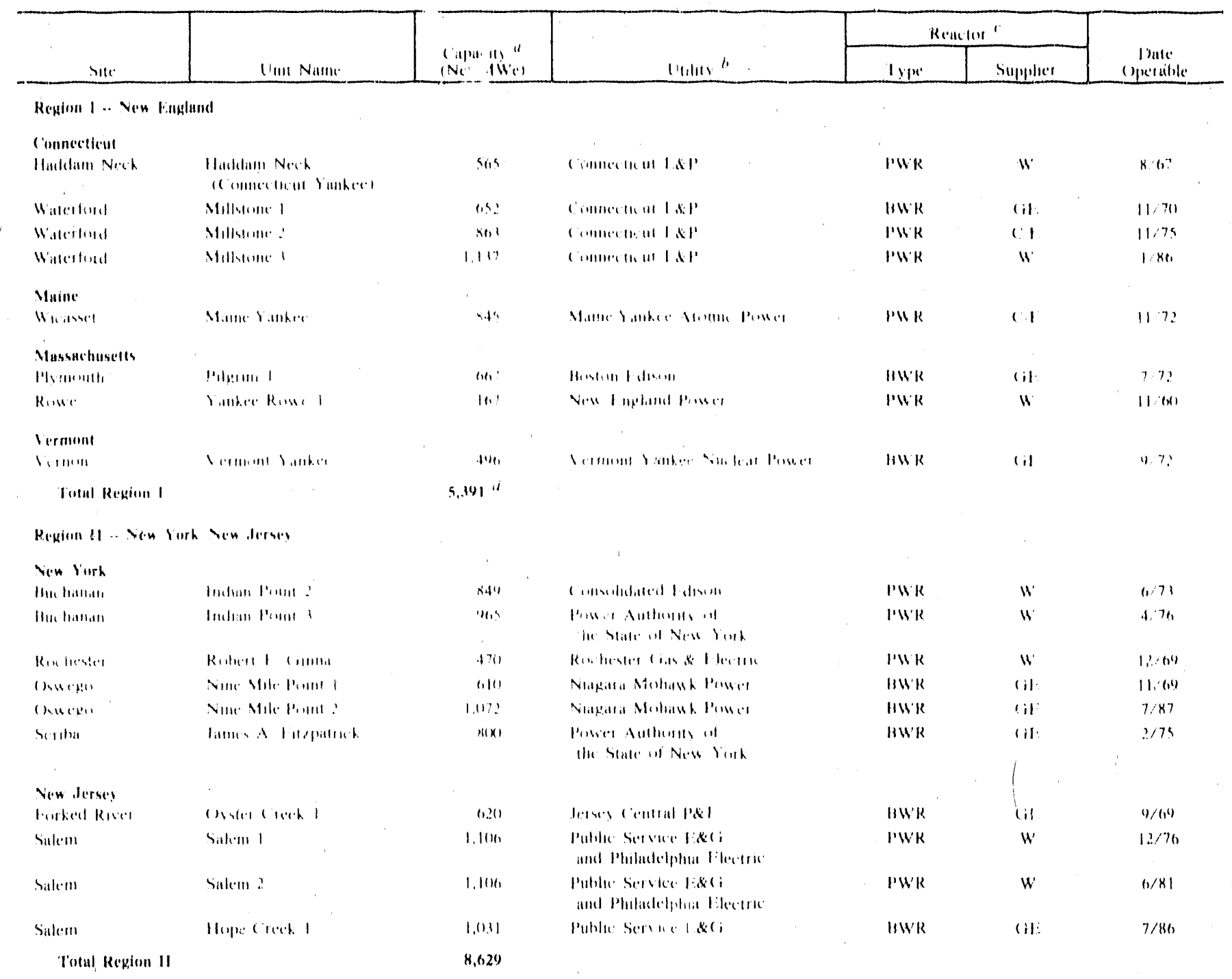

See finstholes all end of tahle. 
Table C1. Roster of U.S. Nuclear Generating Units Operable as of December 31, 1989, by Federal Region and State (Continued)

\begin{tabular}{|c|c|c|c|c|c|c|}
\hline \multirow[b]{2}{*}{ Site } & \multirow[b]{2}{*}{ Uniil Name } & \multirow{2}{*}{$\begin{aligned} \text { Capncity a } \\
\text { (Ne) MWU } \\
\end{aligned}$} & \multirow[b]{2}{*}{ Unilly" } & \multicolumn{2}{|c|}{ Rencitor ${ }^{\prime}$} & \multirow{2}{*}{$\begin{array}{l}\text { Dille } \\
\text { Operanle }\end{array}$} \\
\hline & & & & $r_{y_{\mu}}$ & Suppllen & \\
\hline \multicolumn{7}{|c|}{ Reglon 111 .. Middlo Atlantlo } \\
\hline \multicolumn{7}{|l|}{ Maryland } \\
\hline Lusby & Calvere cliffs 1 & 825 & Hahtimate (1\&1: & IPWR & $(1)$ & $1 / 75$ \\
\hline L.ustly & Culvert clitis 2 & 825 & Baltimore (IdEL: & PWR & $(-1:$ & $12 / 76$ \\
\hline \multicolumn{7}{|l|}{ Ponnsylvanla } \\
\hline Berwick & Suscpuchuman 1 & $1,(150)$ & Pennsylvinita PRI. & BWR & (11): & $11 / 82$ \\
\hline Burwick & Susquehunnu 2 & 1,050 & Pemensylvania Prol. & BWK & (it: & $6 / 84$ \\
\hline Middlicluwn & Three Mile Istand I & 8018 & Metropolitun Edisom & PW'R & $H \& W$ & $6 / 74$ \\
\hline Lankaster & I'anch Botlom 2 & $1,0.51$ & 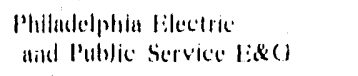 & HWR & (H): & $2 / 14$ \\
\hline L.anciasler & Peach Bestom \& & $1,03.5$ & $\begin{array}{l}\text { Philadelphia Slectric } \\
\text { and 'Public Service S:\&e }\end{array}$ & HWR & (it: & $9 / 74$ \\
\hline P'ottstonnt. & 1.imerick 1 & $1,(19.5$ & Philadelphia t:kestric & HWk & (iil: & $x / 85$ \\
\hline P'ollstuw:I & 1.imerick 2 & 1,055 & Philucledphin Llacersic & IIWK & (11): & $x / x^{\prime}$ \\
\hline Shippingport & Heaver Vulley I & 810 & Duquesme lighl & I'W'R & $w$ & $6 / 76$ \\
\hline shapplungpert & Heaver Valley 2 & 8.11 & 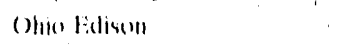 & I'WR & $w^{\prime}$ & $8 / 87$ \\
\hline \multicolumn{7}{|l|}{ V'irkiniu } \\
\hline Surry & Surry 1 & 781 & Vinginin blectric \& bower & IWK & $w^{\prime}$ & $7 / 72$ \\
\hline Surry & Surry 2 & 781 & Virguna lilectric \& lowet & PWR & $w$ & 3,73 \\
\hline Minerul & North Auna I & 91.5 & Virpinin Itectric \& lower & P'W'R & $w$ & $4 / 74$ \\
\hline Minceral & Nurth Amma 2 & 1115 & Virgumu I:lectric \& Powet & $P W^{\prime}$ & w & $8 / 80$ \\
\hline Tutal Keston 111 & & 13,789 & & & & \\
\hline \multicolumn{7}{|c|}{ Reglon IS .. South Atlantic } \\
\hline \multicolumn{7}{|l|}{ Alabamu } \\
\hline meatur & |lowem lexts 1 & $1,(16,5$ & 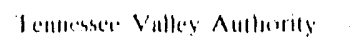 & $M W R$ & (il) & $111 / 71$ \\
\hline |xстин & Buwm lary a & $1,101,5$ & Tenumbsece Vialley Authorily. & MWR & (i): & $x / 74$ \\
\hline आrantuा & Hrowm lerty 1 & $1,(16,5.5$ & lenursese Vulley Authorlly & $M W R$ & (il: & $9 / 76$ \\
\hline Dethitn & loweph M larley 1 & Siti & Alatama Poster & l'W'R & $W^{\prime}$ & $x / 77$ \\
\hline Duthan & duseph M latley? & $k 25$ & Alabonar linwer & PW'R & $w$ & $5 / 81$ \\
\hline \multicolumn{7}{|l|}{ fluridu } \\
\hline Filcurla cirs & lankey P'ullul & twet & 1\%urla lise & liwk & $w$ & $11 \%$ \\
\hline Flumbla ( w) & lurkey Promen at & $\operatorname{tas}(x)$ & 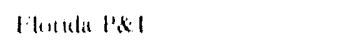 & PWK & $w$ & $6 / 7,3$ \\
\hline H. Preter & s) 1 we 1 & 834 & liluntar Pise. & PWR & $(\because)$ & 5,76 \\
\hline H Punce & si 1 14\%? & $x m$ & Herrda Pel & INK & $(\cdot)$ & $6,8.1$ \\
\hline$R+.11 \cdots+.1$ & insal kwers & $1,6+1$ & 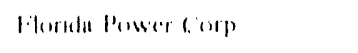 & INW & $H E W$ & 177 \\
\hline \multicolumn{7}{|l|}{ Geurgit } \\
\hline Puxley & Hatth 1 & $7(x)$ & Eientral Power & HWR & (il: & $11 / 74$ \\
\hline Haxley & Huth: & 772 & licorgial : eweret & $\| W^{\prime} R$ & (it) & $9 / 7 k$ \\
\hline Wistymetorer & Vugnle 1 & 1,01866 & Georgia Hower & l'WR & $w$ & $1 / 87$ \\
\hline 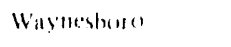 & Vuglle? & $1,(1866$ & Cincurgia Prowere & l'WR & W & $1 / k 9$ \\
\hline \multicolumn{7}{|l|}{ Mijssissippl } \\
\hline Port Cintisem & (irand ciulf l & $1.14 ?$ & System linergy Rosururces, lex. & HWR & (1): & $19 / 84$ \\
\hline
\end{tabular}

See fortuntes at end of table. 
Table C1. Roster of U.S. Nuclear Generating Units Operable as of December 31, 1989, by Federal Reglon and State (Continued)

\begin{tabular}{|c|c|c|c|c|c|c|}
\hline \multirow[b]{2}{*}{ Silte } & \multirow[b]{2}{*}{ Umil Namer } & \multirow{2}{*}{ 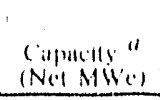 } & \multirow[b]{2}{*}{ Unil1y" } & \multicolumn{2}{|c|}{ Renetent' } & \multirow[b]{2}{*}{ 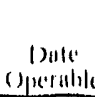 } \\
\hline & & & & 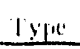 & Supplier & \\
\hline \multicolumn{7}{|c|}{ 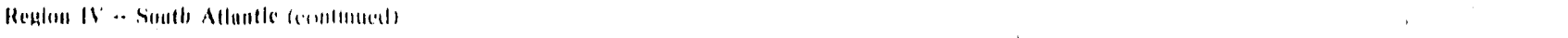 } \\
\hline \multicolumn{7}{|l|}{ North Curulinu } \\
\hline 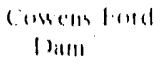 & Mecinise I & 1.124 & lowke lenwel & l'W'R & W' & $17 / 81$ \\
\hline 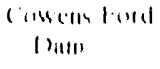 & Meclumst :! & 1.124 & Dence lenwer & I'WR & W & $\because / 81$ \\
\hline$N \cdot \cdots H i l l$ & 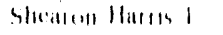 & 861,1 & Cimblitan lise & WW'K & (il) & $1 / 87$ \\
\hline 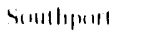 & 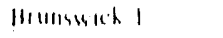 & $7(1)$ & Carrellma lidel. & $11 W k$ & (i): & $12 / 7 k$ \\
\hline Sinuthpurit & Brumnkt: : & $7(1)$ & Callolima lisel & WWR & (i): & $4 / 79$ \\
\hline \multicolumn{7}{|l|}{ South f'urolima } \\
\hline$(\operatorname{line})$ & (alawhas) & 1.121 & 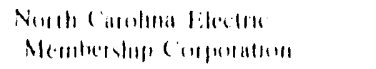 & rW'k & W & $1 / 85$ \\
\hline (liner & (allintia? & $1.12 \%$ & 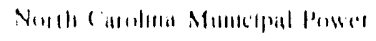 & IWR & W & $s / k \theta_{1}$ \\
\hline$\| 1114: 11 t$. & 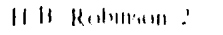 & $1,1,4$ & Canchlins likl. & IWK & W & $9 / 71$ \\
\hline $\mid \cdot \cdots+m+1) ! \mid$ & sulı!1:! 1 & $s, 85$ & 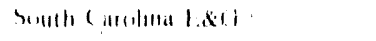 & IWR & w & $11 / k ?$ \\
\hline hint:us & $(x+1)+e)$ & sitis & Huke Pinn' & PWk & H\&W & $s / 1$ \\
\hline 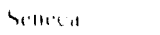 & 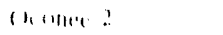 & $x+11$ & Huke Henwer & PW'R & HidW & $12 / 71$ \\
\hline sellenil & (1) +neter 1 & s.to & Huke Hunet & l'M'R & HEW & $11 / 74$ \\
\hline \multicolumn{7}{|l|}{ Iermessere } \\
\hline Willy & 4.tumith 1 & $1.14 x$ & 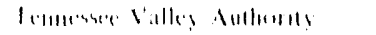 & IWk & W & $7 / 80)$ \\
\hline 1):11, & 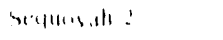 & $1.1 .4 \%$ & 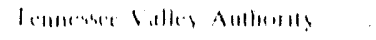 & INR & W' & $12 / 41$ \\
\hline Inteil Resin & & $26,6,697 d$ & & & & \\
\hline \multicolumn{7}{|c|}{ 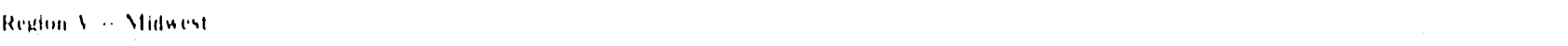 } \\
\hline \multicolumn{7}{|l|}{ Illimoir } \\
\hline $\mid 1+11 !, 1: 1,0)$ & $\mid$ Hrdtumand & $1,(1,11)$ & 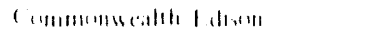 & l'Wk & 4 & $7: k ?$ \\
\hline 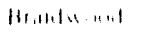 & 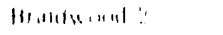 & 1.1411 & 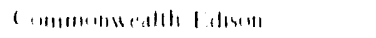 & lWk & W & sikk \\
\hline H、..." & आイルा & 1.1 .11 & 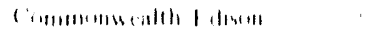 & lWk & W & $\therefore$ nis \\
\hline आいい & $\| x+\cdots \mid \cdot$ & 11211 & 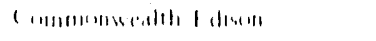 & PWR & $w$ & $1 / k\rangle$ \\
\hline $1 \mathrm{in+1.+11}$ & $(\mid n+1, n) \mid$ & 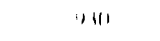 & 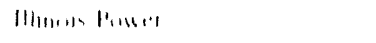 & MWR & (i) & $4 \times 3$ \\
\hline $1+1, \cdots, 1$ & $1 ! 14,1,1111,1$ & ${ }^{2}+64$ & 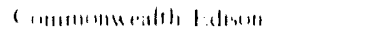 & FWK & (i) & $4 \%$ \\
\hline 1 แ小, & 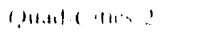 & $" 1,1$ & 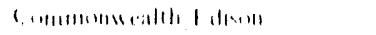 & MWR & (i) & 82 \\
\hline YHon & 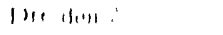 & $\because$ & 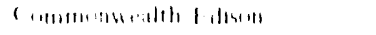 & $M W k$ & (i) & $4 \cdot 71$ \\
\hline$M \cdots 11$ & |mblen & 77 & 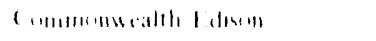 & WWK & (i) & $7 \% 1$ \\
\hline ren. & | $14,1 H_{1} \mid$ & 1.14 .4 & 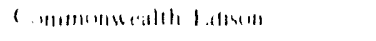 & $11 W \mathrm{R}$ & (i): & $4:$ : \\
\hline ?m a & $|, 16,1| \ldots !$ & $1.14 \%$ & 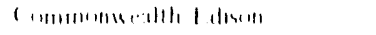 & WW'K & (i) & $1 / x .4$ \\
\hline An+ & 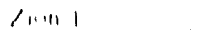 & $1,(1,4)$ & 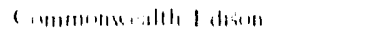 & IWK & 11 & 1.71 \\
\hline$\therefore \cdots$ & /M. & $1.1+411$ & 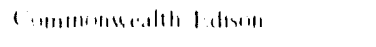 & PWk & II & 1271 \\
\hline \multicolumn{7}{|l|}{ Vichigan } \\
\hline fhuthrthas & 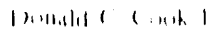 & 1,11111 & 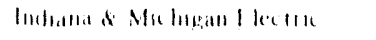 & IWR & W & $\therefore 74$ \\
\hline$\|m\|_{2}^{\prime}|m| \omega_{1}$ & 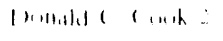 & $1.1(x)$ & 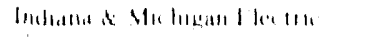 & IWR & II & $1.7 x$ \\
\hline (horlentul & Hit: Ront Hentur & 117 & 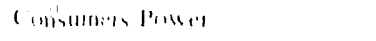 & $M W k$ & (i): & $1: 1 / 6 !$ \\
\hline vinfmin & 1,rm! : & $1.11 \% \mathrm{~s}$ & 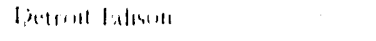 & आW'K & (i): & $7 \times 5$ \\
\hline s.tull $11 \ldots, \cdots$ & P'illsidilin & 795 & 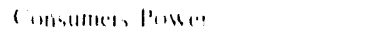 & lW's & 1.1 & 1271 \\
\hline
\end{tabular}

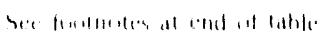


Table C1. Roster of U.S. Nuclear Generating Units Operable as of December 31, 1989, by Federal Region and State (Continued)

\begin{tabular}{|c|c|c|c|c|c|c|}
\hline \multirow[b]{2}{*}{ Sille } & \multirow[b]{2}{*}{ Unil Nanic } & \multirow{2}{*}{$\begin{array}{l}\text { Canplilly" } \\
\text { (Nol Muve) }\end{array}$} & \multirow[b]{2}{*}{ Litility" } & \multicolumn{2}{|c|}{ Krimeter" } & \multirow{2}{*}{ 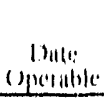 } \\
\hline & & & & "lyen & Sunpelien & \\
\hline \multicolumn{7}{|c|}{ Replon V.. Mldwest (comlinued) } \\
\hline \multicolumn{7}{|l|}{ Mllmmesutu } \\
\hline Munilicelles & Munticellos & 5.11 & 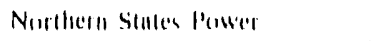 & HW'K & (il: & $1 / 11$ \\
\hline Kut W'ing & Pralrie Island I & $5(1) .4$ & Nertherus Stuter l'ower & PWR & $w^{\prime}$ & 12,71 \\
\hline Rosl Wing & I'rairie |aland: & $\$ 104$ & Nurllheren Stutes Poweres & jWK & W & $12 / 4$ \\
\hline \multicolumn{7}{|l|}{ (H)io } \\
\hline Oak Harhou & 1)avin. Hesse I & $x s+1$ & Clevelunnt blece Hlum. & pWk & HWW & $\times 77$ \\
\hline Norill liensy & P'erry 1 & $1.1 \times 5$ & ()hice lidisent & HW' & (ii) & 11 \\
\hline \multicolumn{7}{|l|}{ W'|scoulsin } \\
\hline c'mllun & kewamert & 510 & W'mbintuin P'ublic Service & I'WK & W' & 1.7 \\
\hline lwo crecths & frome bench I & $4 \times 5$ & Wisconsiun blestroc Power & PW'k & W' & $11 / 71$ \\
\hline Iwo crecks & Printur Henche & $4 k 5$ & Wimerisun flectre Puwer & INR & 11 & $x / 72$ \\
\hline Totul Reglen & & 21,670 & & & & \\
\hline \multicolumn{7}{|c|}{ Reglen VI .. Southrest } \\
\hline \multicolumn{7}{|l|}{ Arkunsals } \\
\hline Russellwille & ARillum, Nucleal 1 & $k ! 1$, & Alkansus lisel & PW'K & MEW & 7.4 \\
\hline Rแ⿻еllvilke & Arhinssis Vucleat : & $x 5 x$ & Arkillsals lidel. & INWR & $(1)$ & $12 / 7 k$ \\
\hline \multicolumn{7}{|l|}{ I. (0uisimun } \\
\hline st Irumandl. & RNe Hend I & 416 & tiulf Stutes l'ullues & IIWK & (i) & $11 / x:$ \\
\hline 1.411 & Waterlents & 1,1175 & 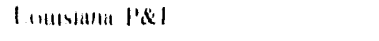 & IWK & ( $1:$ & 1,45 \\
\hline \multicolumn{7}{|l|}{ levis } \\
\hline Mins ( I) & Sirull) lavirs 1 & 1.251 & 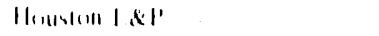 & JWK & $w^{\prime}$ & $1 / x 8$ \\
\hline $11,1,113$ & Sumlle lasils: & 1.251 & $\|$ Hunten $\mid \& \|^{\prime}$ & INR & $\mathbb{W}$ & $1: x i$ \\
\hline Intul Repilut & & 6,2066 & & & & \\
\hline \multicolumn{7}{|c|}{ Region Vll .. Cintersl } \\
\hline \multicolumn{7}{|l|}{ lun॥ } \\
\hline Hitlu & Buther Armilal & $s(x)$ & 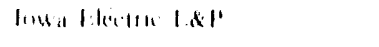 & IIW'R & (i) & 914 \\
\hline \multicolumn{7}{|l|}{ kinlsis } \\
\hline Hurlmpt+1" & Wrilt ( weth & $1.12 x$ & 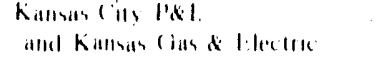 & l'WR & 14 & $5 / 45$ \\
\hline \multicolumn{7}{|l|}{ Vissumer } \\
\hline$|u| t+11$ & (allatuas 1 & $1.11 \mathrm{k}$ & H'mon Ilectrie & PWK & W' & $111 ; k 4$ \\
\hline \multicolumn{7}{|l|}{ Vebrusku } \\
\hline Hunsusille & (in) & $77 k$ & 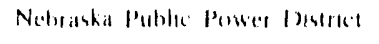 & IIWR & (ill: & $5 / 7.4$ \\
\hline Pand callwum & 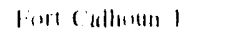 & $47 t$ & 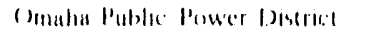 & H'K & (') $1:$ & $8 / 7.1$ \\
\hline lotul Reglet & & 4,000 & & & & \\
\hline
\end{tabular}

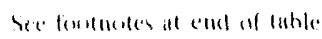


Table C1. Roster of U.S. Nuclear Generating Units Oferable as of December 31, 1989, by Federal Region and State (Continued)

\begin{tabular}{|c|c|c|c|c|c|c|}
\hline \multirow[b]{2}{*}{ Sille } & \multirow[b]{2}{*}{ 1/liil Namic } & \multirow{2}{*}{ 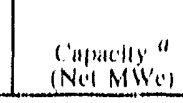 } & \multirow[b]{2}{*}{ Ulilley" } & \multicolumn{2}{|c|}{ Kenten: } & \multirow{2}{*}{ 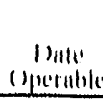 } \\
\hline & & & & Tyж & Suppolier & \\
\hline \multicolumn{7}{|c|}{ Rentum IS .. Wrest } \\
\hline \multicolumn{7}{|l|}{ Arlinum! } \\
\hline Wintershomes & Prulu Verral & 1.221 & 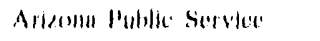 & IWR & $(\cdot 1)$ & b/rs \\
\hline Wintersturteg & l'ulu Verser: & 1.221 & Artanim Prublite Servide & I'W'R & $(\because 1 !$ & $1 / 80$ \\
\hline Winterabuity & I'ulu Verde! & 1.221 & 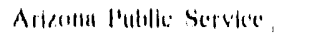 & INWK & $(\because 1:$ & $\mid 1 / 4 \|$ \\
\hline \multicolumn{7}{|l|}{ C'alliformia } \\
\hline Avila Hench & 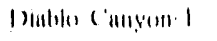 & 1,671 & 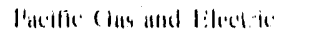 & l'WR & $w$ & $11 / 8.1$ \\
\hline Avilu Hench & 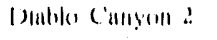 & $1,(1700$ & l'weific (ian and l:kectric & PW'R & W & $1 / 8.5$ \\
\hline ('liny Stittinn) & Rurberesero & $4 \% 1$ & 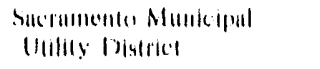 & PWR & Hisw & 111,74 \\
\hline Sill chementille & Sinn (Amelite 1 & 1.16 & 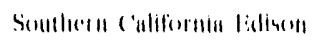 & PWR & $w$ & $1 / 6 \%$ \\
\hline 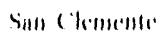 & Sand (1) & $1,0 \%$ & 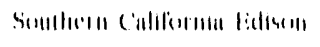 & INWR & ( 11 & 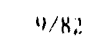 \\
\hline 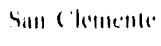 & 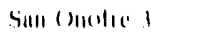 & 1,0801 & 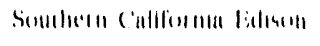 & PWK & $(\cdot 1:$ & $11 / x .1$ \\
\hline 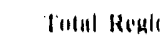 & & $4,27.4$ & & & & \\
\hline \multicolumn{7}{|c|}{ Reglon $\times$.. Northwest } \\
\hline \multicolumn{7}{|l|}{ (Orrден } \\
\hline Prescult & 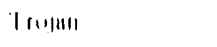 & 1.111 .1 & 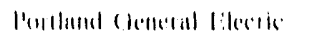 & H'N & $w$ & $12 / 75$ \\
\hline \multicolumn{7}{|l|}{ Wushlmaton } \\
\hline Ruhliannl & WNI: & $1.1(x)$ & 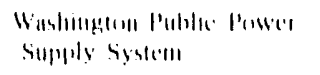 & HW'R & (ili: & $4 / x .4$ \\
\hline Intul Rruin & & 2,2114 & & & & \\
\hline Thtul liniterel & (1) $|\ln |(s)$ & $97,8(19)$ & & & & \\
\hline
\end{tabular}

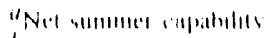

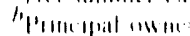

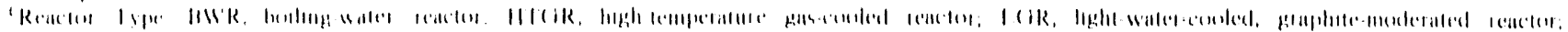

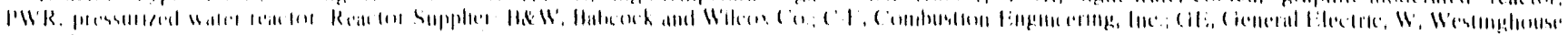

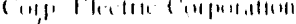

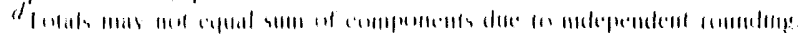

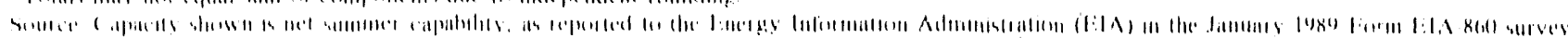




\title{
Appendix D
}

\author{
U.S. Nuclear
}

Generating Units

in the

Construction Pipeline as of

December 31, 1989 


\section{U.S. Nuclear Generating Units in the Construction Pipeline as of December 31, 1989}

Table D1. Roster of U.S. Nuclear Generating Units in the Construction Pipeline as of December 31, 1989, by Federal Reglon and State

\begin{tabular}{|c|c|c|c|c|c|c|c|c|c|c|}
\hline \multirow[b]{3}{*}{ silte } & \multirow[b]{3}{*}{ I'mill Nallu. } & \multirow{3}{*}{ 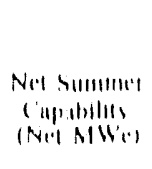 } & \multirow[b]{3}{*}{ l'ullu!" } & \multirow{2}{*}{\multicolumn{2}{|c|}{ Rinulen" }} & \multicolumn{2}{|c|}{ Stul114: } & \multicolumn{3}{|c|}{ 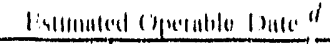 } \\
\hline & & & & & & \multirow{2}{*}{ 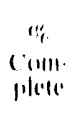 } & \multirow[b]{2}{*}{$\begin{array}{l}11 . \\
\text { anilue }\end{array}$} & \multirow[b]{2}{*}{ llillly } & \multicolumn{2}{|c|}{$11 A^{\prime \prime}$} \\
\hline & & & & $\left.|s|\right|^{\prime}$ & $\begin{array}{l}\text { Sulp. } \\
\text { flle' }\end{array}$ & & & & l.R & $11 k$ \\
\hline \multicolumn{11}{|c|}{ Reston I.. V'n lingland } \\
\hline 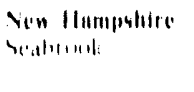 & 'vallowel 1 & 1.1811 & 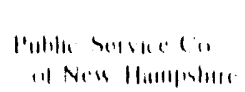 & p'k & N' & $\mid(k)$ & $1.1^{1}$ & $1 / 111$ & 1. 401 & $(1,101)$ \\
\hline Intul Rerglun I & & 1,1501 & & & & & & & & \\
\hline Rentill II.. & $\begin{array}{l}\text { Vun Yin'k Jink } \\
\text { Jirsey }\end{array}$ & $11^{\prime \prime}$ & & & & & & & & \\
\hline Henion $\|I\|$. & Mededte Allamele & 11 & & & & & & & & \\
\hline \multicolumn{11}{|c|}{ 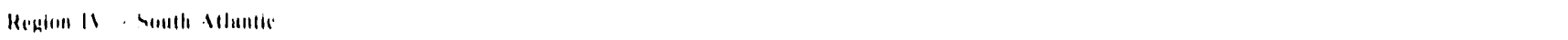 } \\
\hline 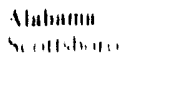 & HeNc|rntr. 1 & $1 . .1 .:$ & 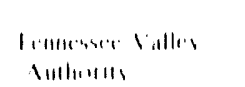 & lWR & HWW & s.9 & (1) & (N) & $11 ! x(x)$ & $12 l(x)$ \\
\hline 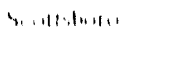 & $\|, \cdot\|_{r} \cdot\left\|_{1}\right\|_{1} \|_{1}:$ & 1..'1: & 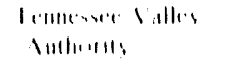 & lWk & HWW & 1, & (1) & (5) & $6.2(x) 1)$ & (b. $2(x)$ \\
\hline 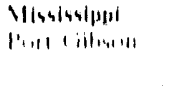 & litimet ctoll! & $1 . \cdot 611$ & 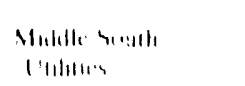 & MWル & 111 & 4.4 & 111 & $(9)$ & $\therefore$ & \\
\hline 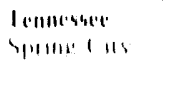 & 16 .111. Haw 1 & 1,1111 & 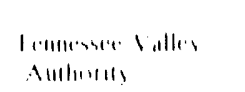 & rW'k & "N & 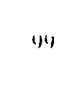 & $(1)$ & 1.01 & (1.4)! & (1.)14! \\
\hline 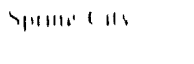 & $16.1111141 !$ & $1.1 \%$ & 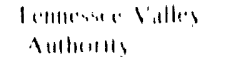 & I'WR & W' & 8.4 & $(1)$ & (4) & $1 / 44$ & $1 / 145$ \\
\hline 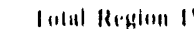 & & $4,(114$ & & & & & & & & \\
\hline \multicolumn{11}{|c|}{ 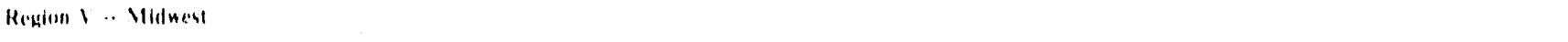 } \\
\hline 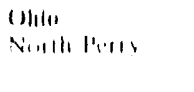 & l'clls: : & $11 \%$ & 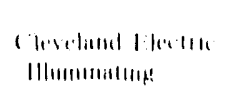 & $\| W ' R$ & (i): & $\omega$ & 111 & $(.5)$ & & $6.2(x) 1)$ \\
\hline 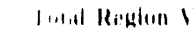 & & 1,174 & & & & & & & & \\
\hline
\end{tabular}


Table D1. Roster of U.S. Nuclear Generating Units in the Construction Plpeline as of December 31, 1989, by Federal Reglon and State (Continued)

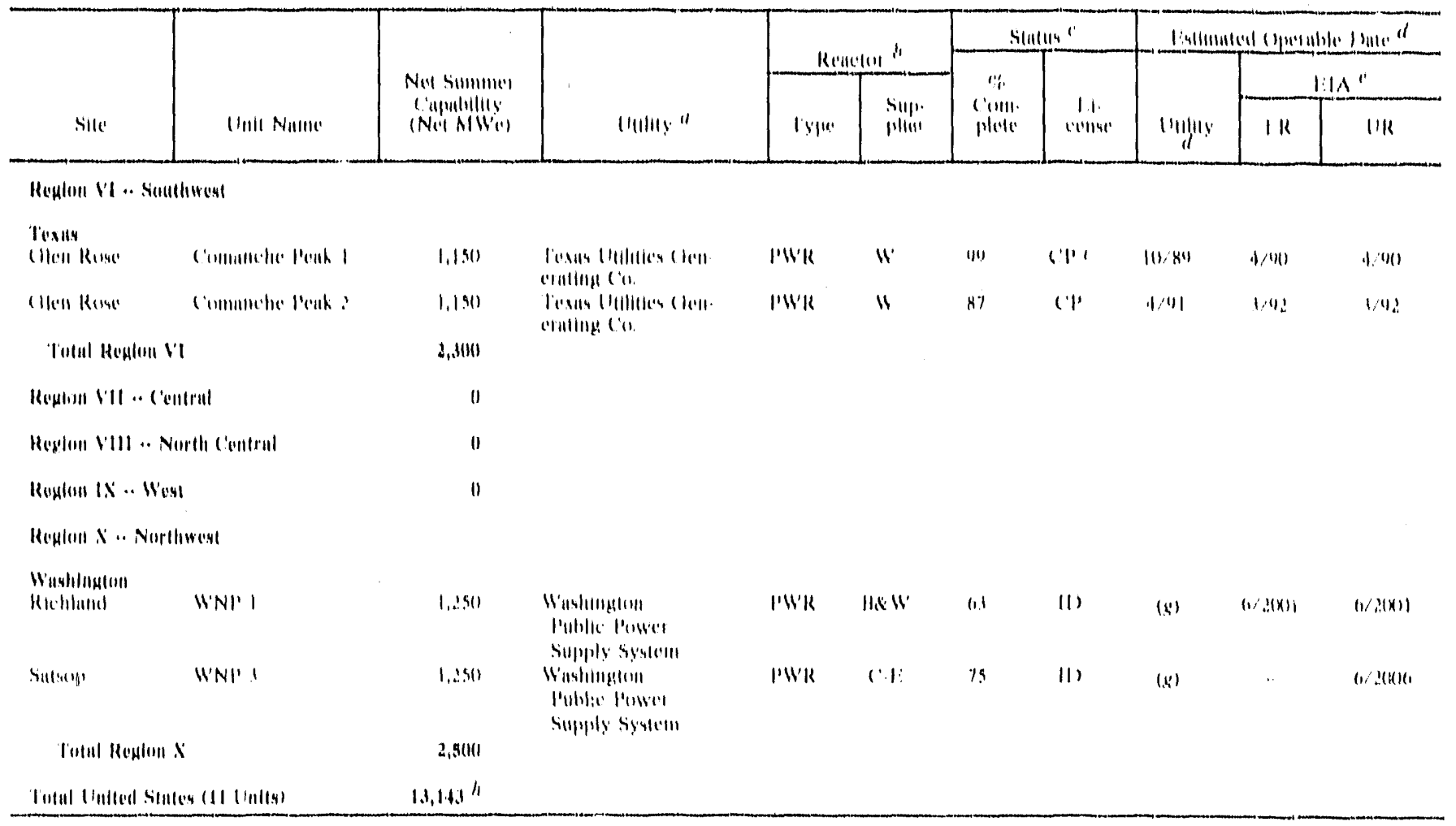

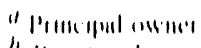

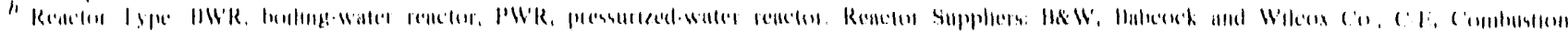

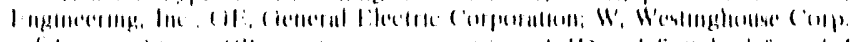

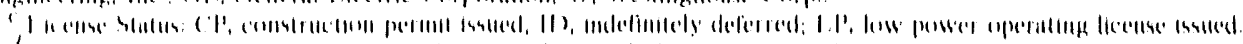

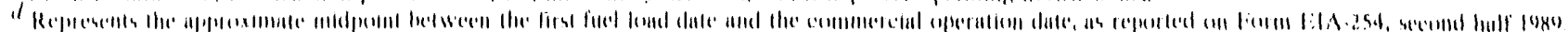

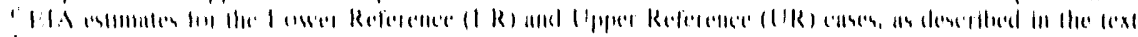

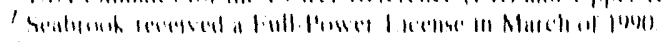

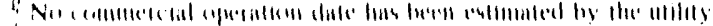

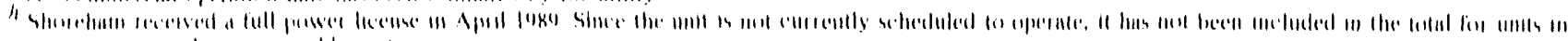

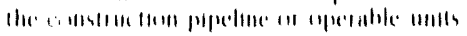

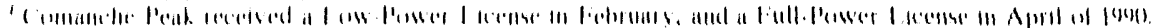

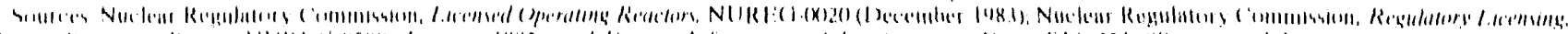

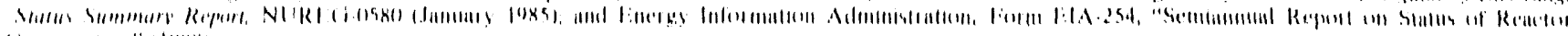
(')114)
} 


\section{Appendix E}

Nuclear

Generating Unit

Reactors Ordered in the

United States, 1953-1989 


\section{Nuclear Generating Unit Reactors Ordered in the United States, 1953-1989}

Table E1. Nuclear Generating Unit Reactors Ordered in the United States, 1953-1989, by Year of Order

\begin{tabular}{|c|c|c|c|c|c|c|}
\hline \multirow[b]{2}{*}{$\begin{array}{l}\text { Yeur } \\
\text { of } \\
\text { Order }\end{array}$} & \multicolumn{2}{|c|}{ Yearly Total } & \multicolumn{4}{|c|}{ Individuat Reactors } \\
\hline & $\begin{array}{l}\text { No. ol } \\
\text { Units } \\
\text { Ordered }\end{array}$ & $\begin{array}{l}\text { Design } \\
\text { Capacity } \\
\text { (MWe) }\end{array}$ & Unit Name & $\begin{array}{l}\text { Design } \\
\text { Capacity } \\
\text { (MWe) }\end{array}$ & $\begin{array}{l}\text { Reactor } \\
\text { Supplicer } "\end{array}$ & $\begin{array}{l}\text { Current Status } \\
\text { (December } 31.1989)\end{array}$ \\
\hline 1953 & 1 & 60 & Shipringnot & 6) & W & $\begin{array}{l}\text { Shut down, 1974. Resumed oncration } \\
\text { in lo77 as a light-water breeder reactor. } \\
\text { Retired in } 1982 \text {. }\end{array}$ \\
\hline 1955 & 2 & 465 & $\begin{array}{l}\text { Indian P'oint } 1 \\
\text { Dresslen I }\end{array}$ & 265 & $\begin{array}{l}\text { B\&W } \\
\text { (il: }\end{array}$ & $\begin{array}{l}\text { Shut down, } 1974 . \\
\text { Operating license withdrawn in } 1980 . \\
\text { Shut down, lo78. } \\
\text { Decommissioning being planned. }\end{array}$ \\
\hline 1956 & 1 & 175 & Y'ankee Ruwe ! & 175 & $W^{\prime}$ & Operating. \\
\hline 1958 & 1 & 65 & Humboldt Bay & 65 & GE: & $\begin{array}{l}\text { Shut down, 1976. } \\
\text { Decommissioning being planned. }\end{array}$ \\
\hline 1959 & 1 & 72 & Big Rock P'oint & 72 & (il: & Operating. \\
\hline 1962 & 2 & 6.32 & 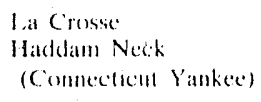 & $\begin{array}{r}50 \\
582\end{array}$ & A.C: & $\begin{array}{l}\text { Retired 1968? } \\
\text { Operating. }\end{array}$ \\
\hline 1963 & 5 & 3,018 & $\begin{array}{l}\text { Malibu } \\
\text { San Onofre: 1 } \\
\text { Hanford-N } \\
\text { Nime Mile Point } 1 \\
\text { Oyster Creck }\end{array}$ & $\begin{array}{l}462 \\
4.36 \\
8.50 \\
620 \\
6.50\end{array}$ & $\begin{array}{l}W \\
W \\
\text { cit: } \\
\text { cil: } \\
\text { Gl: }\end{array}$ & $\begin{array}{l}\text { Canceled, } 1972 . \\
\text { Operatting. } \\
\text { Shin downd, } \\
\text { Shut down. Restart planned for } 8 / 89 \text {. } \\
\text { Operating. }\end{array}$ \\
\hline 1965 & 7 & 4,475 & 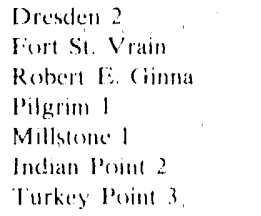 & $\begin{array}{l}794 \\
3.30 \\
470 \\
6595 \\
660 \\
87.3 \\
69.3\end{array}$ & $\begin{array}{l}\text { Gil: } \\
\text { GA } \\
\text { W } \\
\text { Gi: } \\
\text { Gi: } \\
W \\
\text { W }\end{array}$ & $\begin{array}{l}\text { Operating. } \\
\text { Shutclown 1989. } \\
\text { Operating. } \\
\text { Operating. } \\
\text { Operating. } \\
\text { Operating. } \\
\text { Operating. }\end{array}$ \\
\hline
\end{tabular}

Ser formotes at end of table 
Table E1. Nuclear Generating Unit Reactors Ordered in the United States, 1953-1989, by Year of Order (Continued)

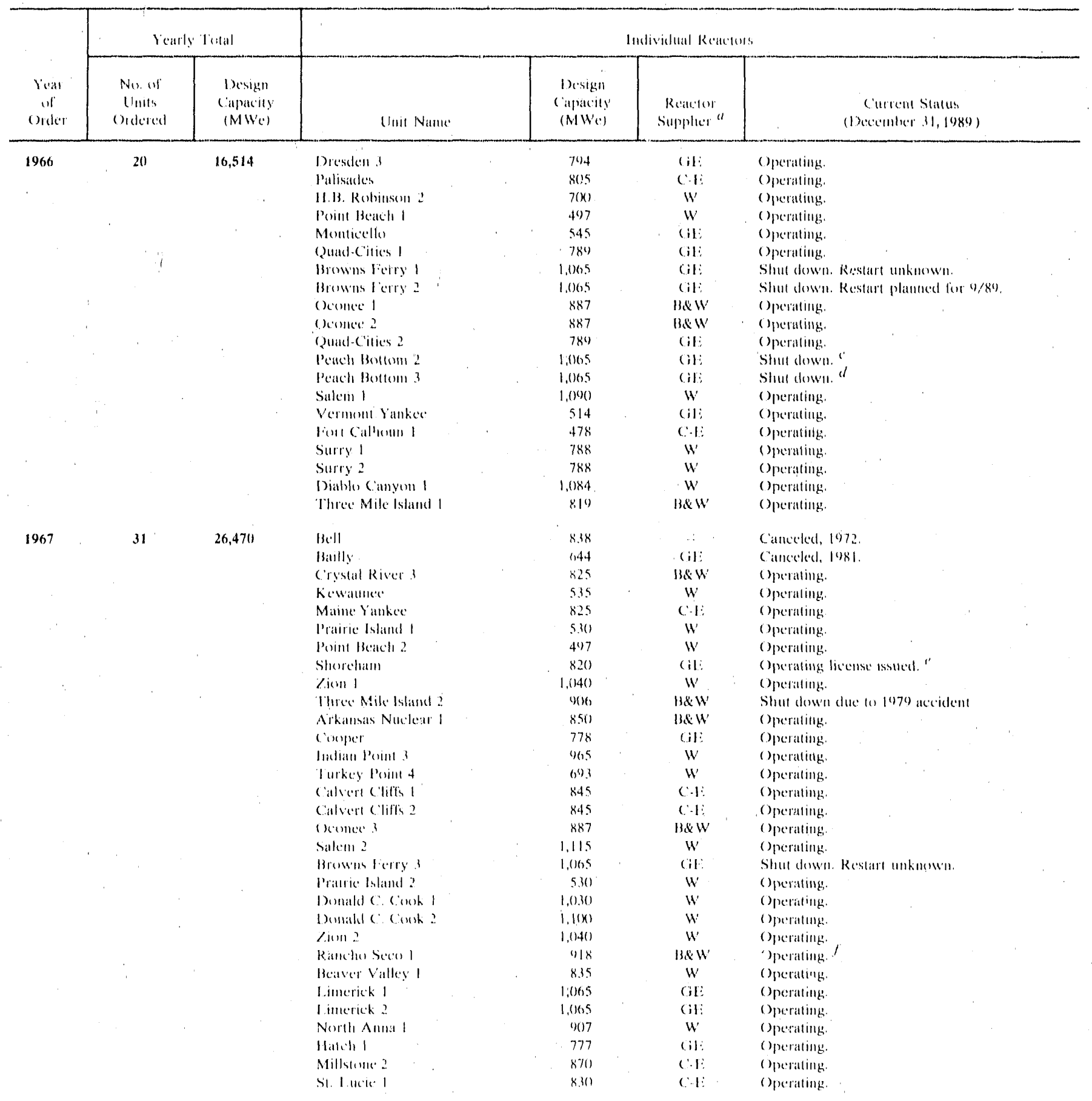


Table E1. Nuclear Generating Unit Reactors Ordered in the United States, 1953-1989, by Year of Order (Continued)

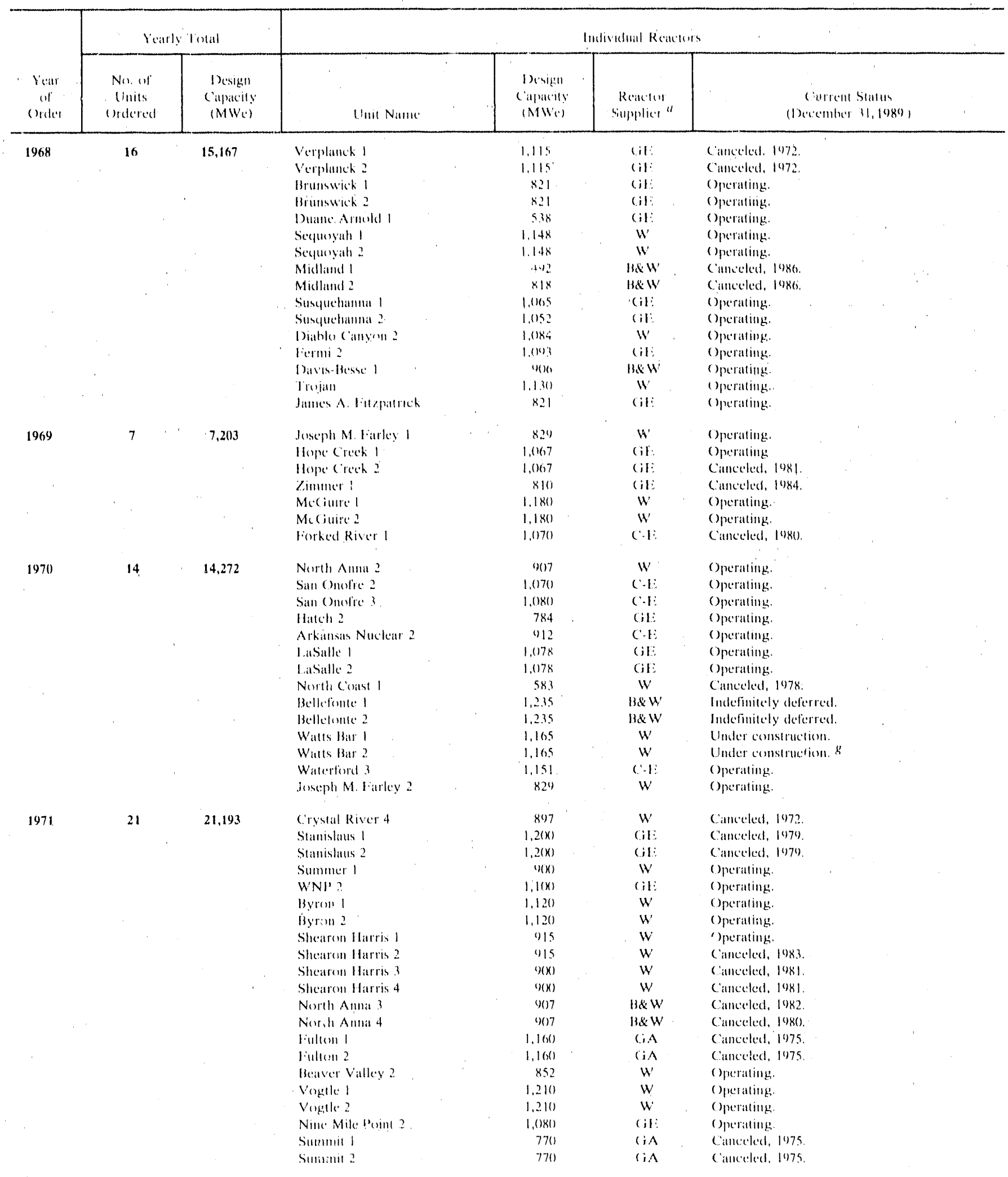


Table E1. Nuclear Generating Unit Reactors Ordered in the United States, 1953-1989, by Year of Order (Continued)

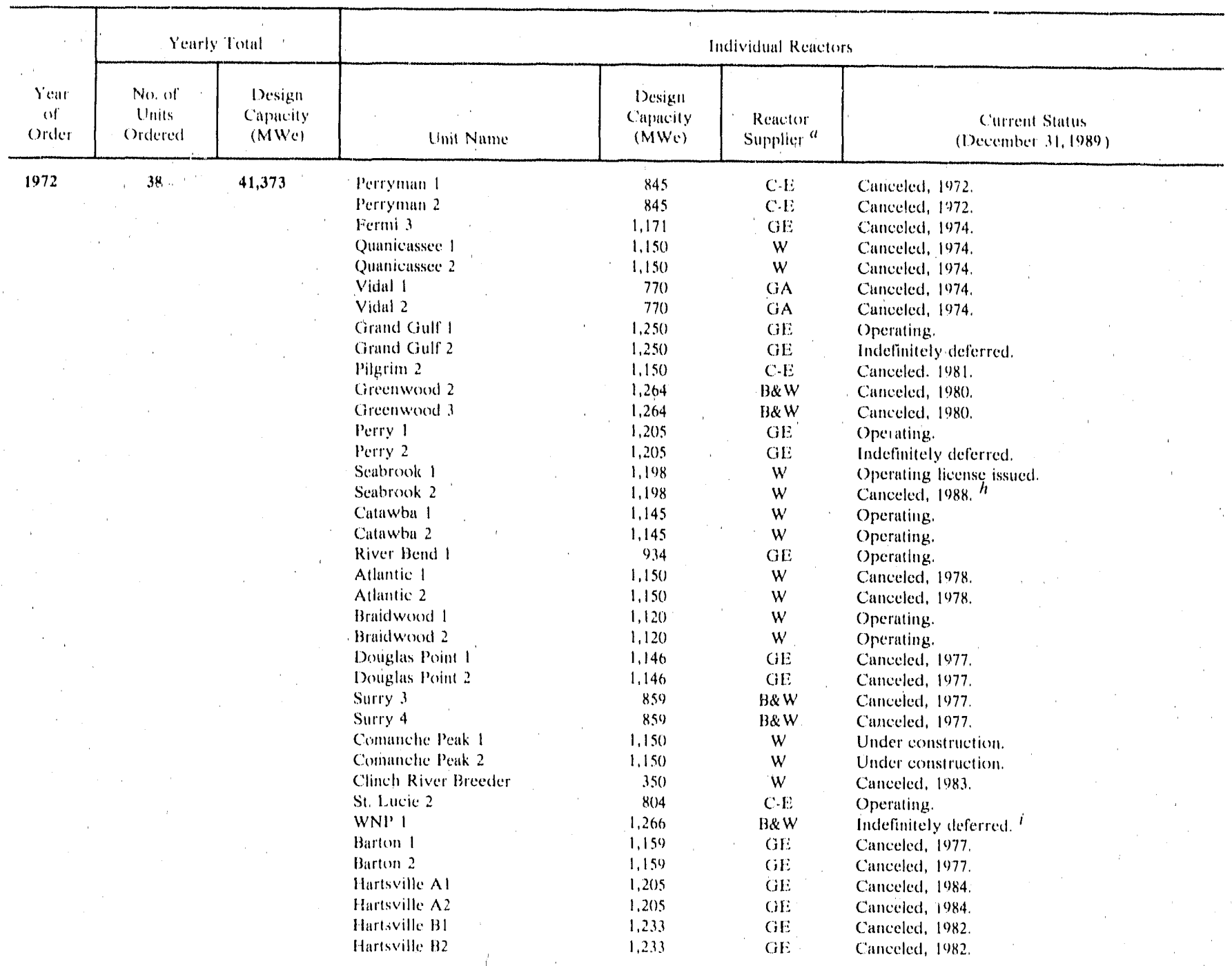

Sec foolnotes at end of lable. 
Table E1. Nuclear Generating Unit Reactors Ordered in the United States, 1953-1989, by Year of Order (Continued)

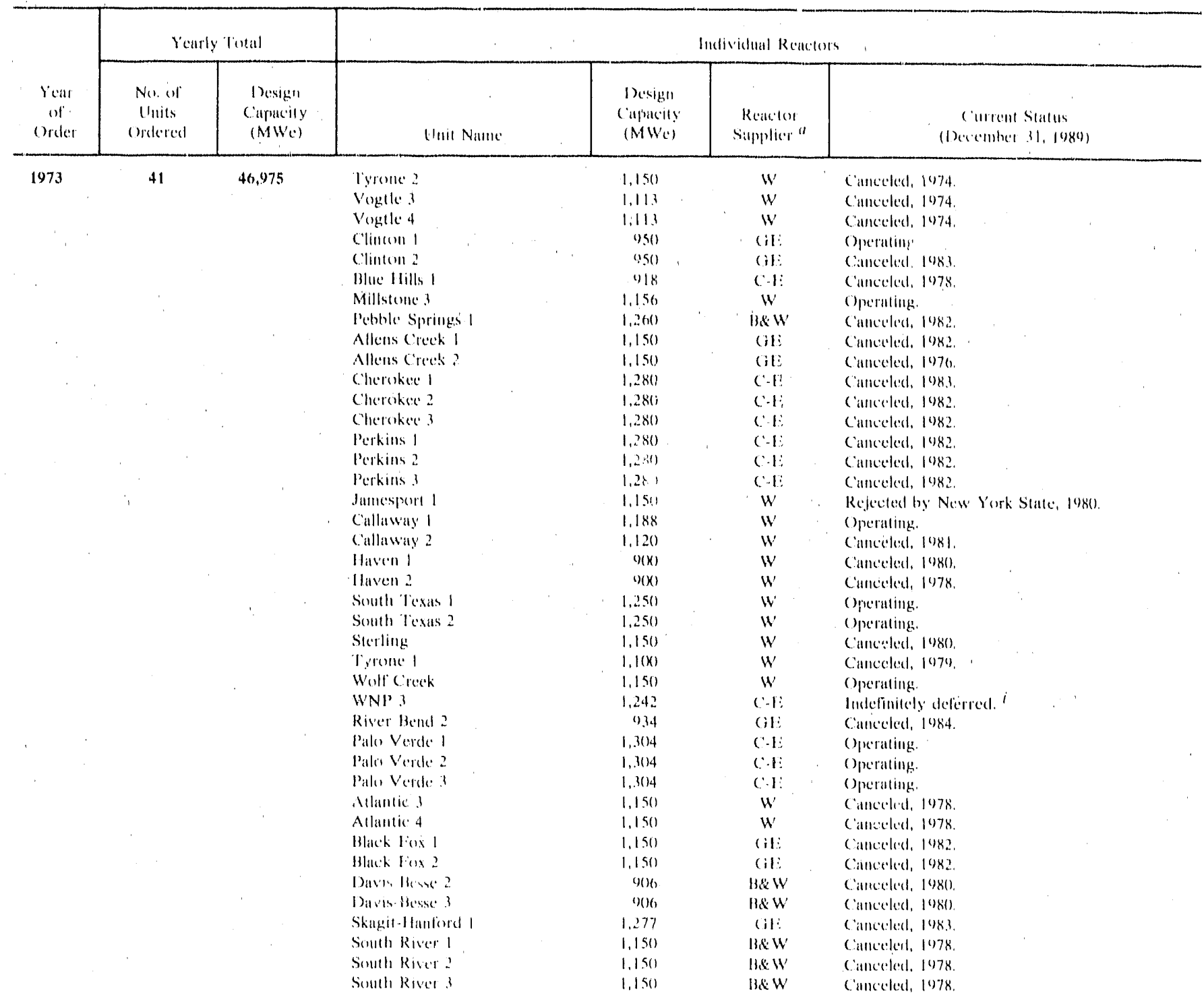


Table E1. Nuclear Generating Unit Reactors Ordered in the United States, 1953-1989, by Year of Order (Continued)

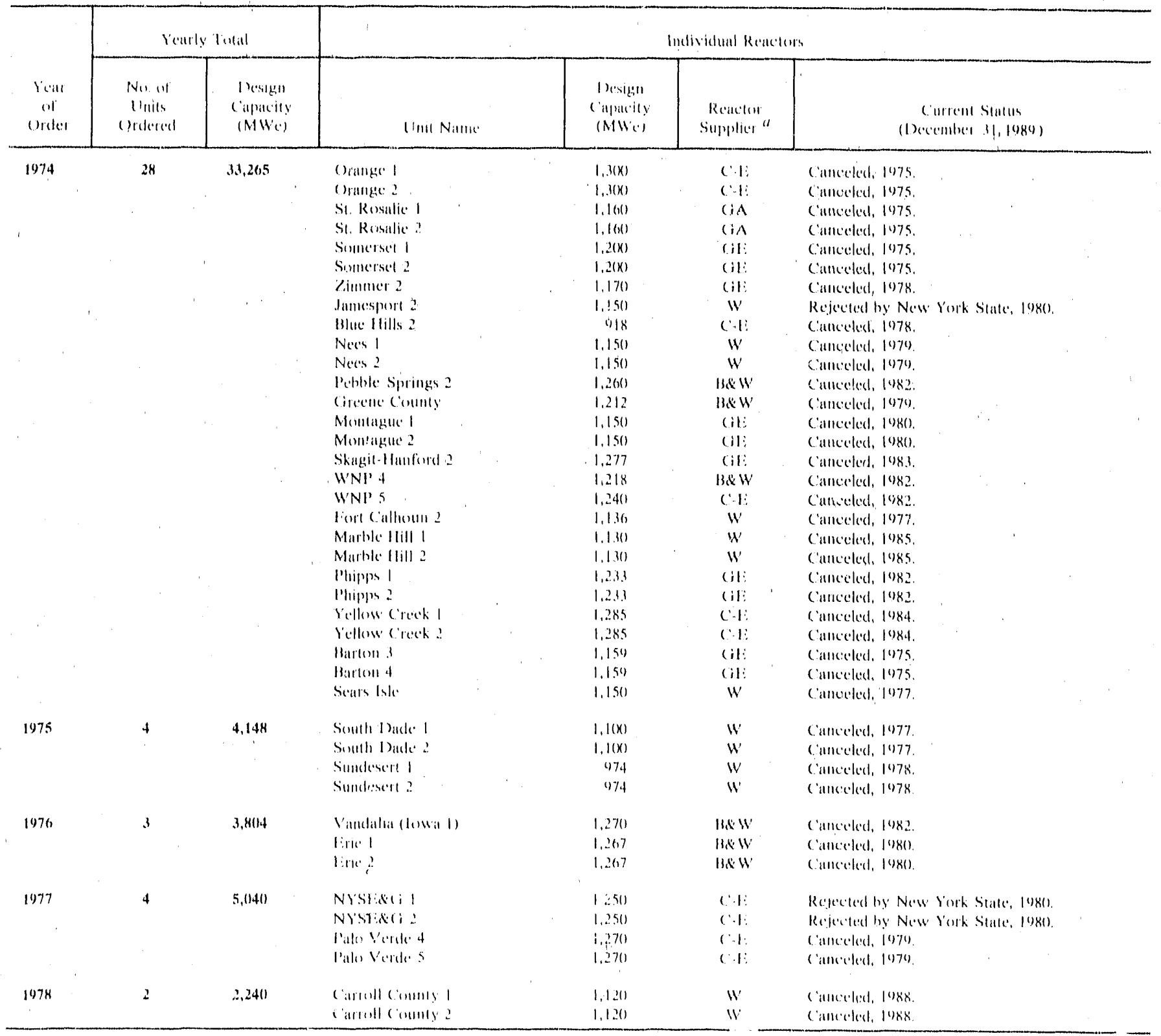

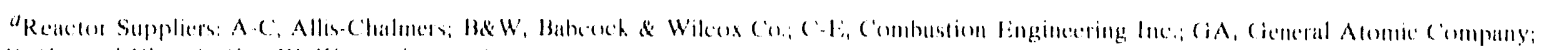

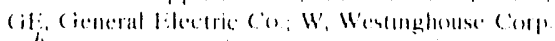

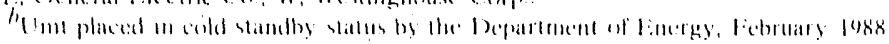

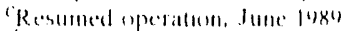

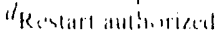

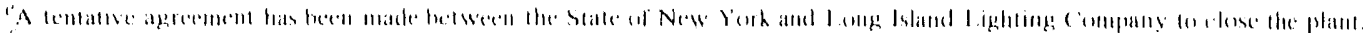

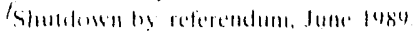

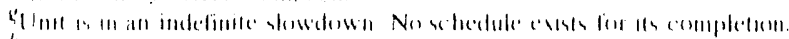

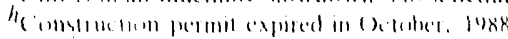

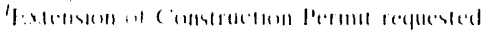

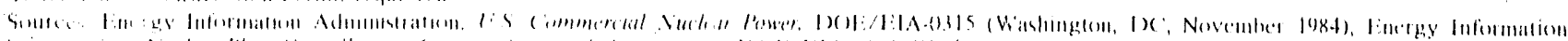

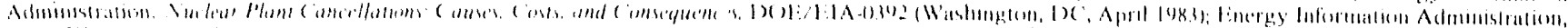

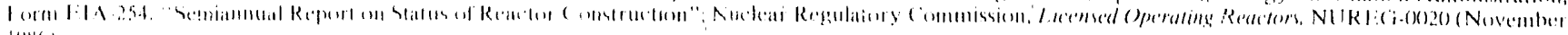
14 (4) 


\section{Appendix F}

Foreign FME

Nuclear

Generating Units

Operable as of

December 31,

1989 


\section{Foreign FME Nuclear Generating Units Operable as of December 31, 1989}

Table F1. Roster of Nuclear Generating Units Operable as of December 31, 1989, in Foreign Countries with FME

\begin{tabular}{|c|c|c|c|c|c|c|c|c|}
\hline Cinnt) & & Unil Natme" & f.xcatlum & $\begin{array}{l}\text { ("I1)ustsy" } \\
\text { (Not MVto) }\end{array}$ & llillity r & $\begin{array}{l}\text { Reacluin } \\
\text { lype: }\end{array}$ & $\begin{array}{l}\text { Renctur } \\
\text { Supplicer }\end{array}$ & $\begin{array}{l}\text { 'Dale of } \\
\text { (1) perations }\end{array}$ \\
\hline \multicolumn{2}{|l|}{ Argentimu } & $\begin{array}{l}\text { Aluchu } 1 \\
\text { limbalwe }\end{array}$ & 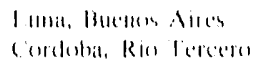 & $\begin{array}{l}3.35 \\
(1)(K)\end{array}$ & $\begin{array}{l}(N N \\
C N\end{array}$ & $\begin{array}{l}\text { I'HWR } \\
\text { IIIW'R }\end{array}$ & $\begin{array}{c}S H S M / K W U \\
\text { AH:CI. }\end{array}$ & $\begin{array}{l}1974 \\
1483\end{array}$ \\
\hline & lutul & 2 l'nits & & 9,35 & & & . & \\
\hline \multirow[t]{8}{*}{ Heluilum } & & $|m| 1 \mid$ & SIIIII) & $4(x)$ & $11)$ & IWK & $A(1)$ & $19 \%$ \\
\hline & & |ric| : & Antwerp & $4(x)$ & II) & I'W'R & AC'l: & 1975 \\
\hline & & $|x| x \mid 1$ & Antwitl? & $y(x)$ & $1: H$ & I'WR & IRAM & 19k2 \\
\hline & & $1)(x: 1+4$ & Anwwels & $1,(11011$ & $1: H$ & I'WK & $A C l:$ & $14 \times 5$ \\
\hline & & lihangere 1 & Huy I ken & 8711 & Sl: & J'W & $A(1.1$ & 1675 \\
\hline & & Thaum, ! & Ilus, I kege & $9(k)$ & $\mathrm{IT}$ & PWK & $\because R A M$ & 1982 \\
\hline & & I shange : & $110 y, 111+10$ & $1 .(1) .010$ & 11 & l'WK & $A C l: C^{\circ}$ & 1985 \\
\hline & Totul & 7 linits & & 5,50110 & & & & \\
\hline \multirow[t]{2}{*}{ Brazil } & & Anptial & |lanthil & $6 \%$ & $13 \%$ & I'W'R & WLSI & 198: \\
\hline & lint:il & 11 'nit & & 620 & & & . & \\
\hline \multirow[t]{19}{*}{ C'unada } & & Huा I I & 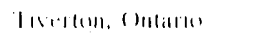 & 704 & (IN & lilW'k & Al:C\%. & 1977 \\
\hline & & Harie : & 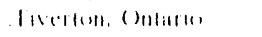 & 76,4 & IN & PIIWR & AFCl. & 1976 \\
\hline & & Haw? & 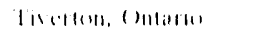 & 76,4 & (JN & HIWK & Al:C 1 & 1977 \\
\hline & & Hatet & 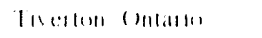 & $7(1)$ & $1) N$ & PIIWR & Al: ' & 1978 \\
\hline & & Hrthe i & liverlun, (Inlatlus & $80(1)$ & $\operatorname{CON}$ & PIINK & Al:Cl. & 1984 \\
\hline & & Hreser & 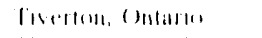 & 817 & $\operatorname{coN}$ & PllWR & Al: 1 & 1984 \\
\hline & & Brw: 7 & 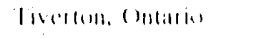 & 8011 & $(\mathrm{~N}$ & PIW'K & AI:C & 1986 \\
\hline & & Howes & lisertem, (mentals & $83 \%$ & $1 \mathrm{~N}$ & PIIIR & Al: $: 1$ & 1987 \\
\hline & & ficmully : & 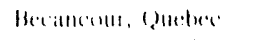 & 6.38 & 110 & PHIWR & AI: 6 & 1042 \\
\hline & & Plucromel & Prokermg, lmatrios & 515 & $1 \mathrm{~N}$ & PlWK & Al:CI. & $|97|$ \\
\hline & & 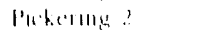 & l'whermge (Mutarks & 515 & $1) \mathrm{N}$ & JHWR & $A l: C \cdot 1$ & 1071 \\
\hline & & l'is herong! 1 & lokermen ontarm. & ils & $6 \mathrm{~N}$ & PIW'K & $A 1: C \%$ & 1072 \\
\hline & & l'rkenng! d & l'kke:ing, ()mark & 515 & $\operatorname{coN}$ & PIIWR & Al:C: & 197.3 \\
\hline & & Jicherums & Imheroms, Intatio & $s / t_{1}$ & () $\mathrm{N}$ & HIW'R & Al:C & $14 \times 2$ \\
\hline & & l'uterlul! & 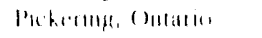 & 516 & $(1 \mathrm{~N}$ & PIIK & 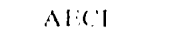 & 194.3 \\
\hline & & I'ukemlin!? ? & 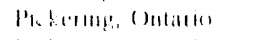 & 316 & $\operatorname{loN}$ & PIIIR & Al:C'I. & 198,4 \\
\hline & & 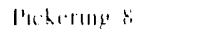 & 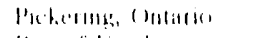 & 516 & $1 \mathrm{~N}$ & PIIW' & $A I: C$ & 1085 \\
\hline & & 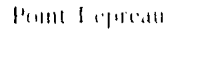 & $\begin{array}{l}\text { Has of lombly. } \\
\text { New Bumbust. }\end{array}$ & $(1 .+1)$ & $\mathrm{NH}$ & PlII'K & $A I: C$ & $198 ?$ \\
\hline & lutisl & is I'nils & & 11,872 & & & & \\
\hline \multirow[t]{5}{*}{ biulund } & & 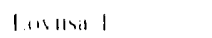 & I. (1) Init & 4.15 & $W^{\prime}$ & INR & NI:I: & 1077 \\
\hline & & l.wilinat? & l nowal & 445 & N' & PW'K & $A I I:$ & $19: 50$ \\
\hline & & ()lkilunen l & 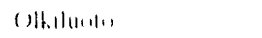 & 7111 & $1 Y^{\prime}$ & HWK & $A \cdot A$ & $10 \% 8$ \\
\hline & & $(3)+114116$. & 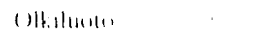 & 7111 & 19 & HW'R & $\triangle A$ & 1980 \\
\hline & | $14 \| u \mid$ & Alinils & & 2,310 & & & & \\
\hline
\end{tabular}


Table F1. Roster of Nuclear Generating Units Operable as of December 31, 1989, in Foreign Countries with FME (Continued)

\begin{tabular}{|c|c|c|c|c|c|c|c|}
\hline cinulley & "Init Namite " & Incition & 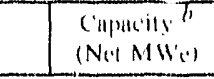 & llitily" & $\begin{array}{l}\text { Renclus } \\
\text { lyped }\end{array}$ & $\begin{array}{l}\text { Rencturs } \\
\text { Supplines" }\end{array}$ & 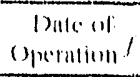 \\
\hline \multirow[t]{3}{*}{ lirunce } & Helleville 1 & c'les: & 1,310 & $1: 1:$ & l'WR & IRAM & $148 \%$ \\
\hline & Helleville 2 & cherer & 1.310 & $1: 1:$ & I'W'K & IKAM & lis88 \\
\hline & Hugesy l & Sin (meni l youn) & $5+10$ & $1 \therefore 1$. & (i) $k$ & $Y A K$ & $10 \% !$ \\
\hline \multirow[t]{4}{*}{1} & Hungey : & Ain & 4.31 & $1: 1 i$ & IIW'K & I:RAM & 1978 \\
\hline & Hugey ? & Aill. & 120 & $1: 1:$ & l'WR & VRAM & 1976 \\
\hline & Bugey of & Ain & $y(x)$ & IH: & IW'R & IRAN & 1070 \\
\hline & Hugeys & Alin & $9(x)$ & $1: 1:$ & l'WR & IRAM & 1070 \\
\hline & Cattenom I & Muscille & $1.3(x)$ & $1: 1:$ & l'WR & FRAM & 1986 \\
\hline & Cottemun! & Mescelle & $1,3(x)$ & $1 \because \%$ & I'W'R & IRKAM & 1987 \\
\hline & Clhinen A. & Indredel-1,aire & 3601 & $1: 1:$ & ( K R & VAK & 1906 \\
\hline & Chimon BI & ludre-cel-1 nire & 870 & I:I: & P'WR & IKAM & $10 \times 2$ \\
\hline & Chinou 12 & 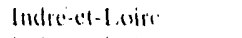 & 870 & $1: 1:$ & I'WR & IRAM & 198.3 \\
\hline & Chinon 13.3 & Inderect-1.rite & $9(0,5$ & $1: 1:$ & P'WR & IRAM & 1980 \\
\hline & Chinon 134 & Inder-et-1.utru & 905 & $1: \mathrm{t}$ & l'WR & IRAM & 1987 \\
\hline & Chour & Ardenimes & 305 & $S N$ & PWR & ACl: & 1907 \\
\hline & ' reys-Mulville & Isterc & $1.2(x)$ & EF: & I.MlillK & NONA & 1986 \\
\hline & (ruas) & Ardecine & 880 & Et: & PWR, & IRAM & 198.1 \\
\hline & Cruas? & Ardectic: & 915 & $\mathrm{BH}$ & PWR & IKAM & 1984 \\
\hline & Cruus 3 & Ardectie: & 8980 & $\mathrm{ES:}$ & PWR & IRAM & 108.4 \\
\hline & Cruas 4 & Ardeche & $\dot{s} 80$ & EI: & I'WR & IRAM & 108.4 \\
\hline & Dampletre 1 & l.oired & $x(x)$ & $\mathrm{EF}$ & PW'R & IRRAM & (1) \\
\hline & Dinmpieste 2 & Lioned & $89(1$ & $1: 1:$ & PWR & liRAM & 1981 \\
\hline & Dompieres & L.oirct & 800 & I:F & PWR & IIRAM & 1981 \\
\hline & Danpierte 4 & loires & $y(x)$ & $E F$ & PWR & INRAM & 1081 \\
\hline & Fessconheim 1 & Haul-Rhin & 880 & $1: 1:$ & l'W'R & FRAM & 1077 \\
\hline & Pessentheim 2 & Huut.Khin & 880 & I:I: & l'WR & IRAM & 1977 \\
\hline & Flamanville 1 & Munche & $1,3,301$ & $1: 1:$ & PWR & IRRAM & 1985 \\
\hline & Plamanville 2 & Mancilie & $1,3.30$ & I:F & PWR & IRAAM & 11986 \\
\hline & Ciravelines 131 & Nerd & 911 & $E:$ & IWR & $I: R A M$ & 1080 \\
\hline & Giravelines 132 & Nord & 9101 & $1 \mathrm{~s}$ & PWR & FRAM & 1980 \\
\hline & Corruelines 13,3 & Nord & 910 & $1: 1$ & l'WR & IRAM & 1981 \\
\hline & Gravelines 134 & Nord & 1) 10 & $1: 1:$ & INWR & IRAM & $\mid 0 \times 1$ \\
\hline & (iravelines $\mathrm{CS}$ & Nord & 910 & $1: 1:$ & IVWR & $F R \wedge N$ & 1084 \\
\hline & Gravelines Co & Nurd & 910 & $\mathrm{El}$ & PWK & IRAM & joxs \\
\hline & I.e Blayilis I & Giforile & 010 & EI: & JWR & FRAM & 1981 \\
\hline & 1, Bluyais ? & Ciironde & 910 & 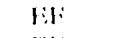 & PWR & $V R A M$ & 1083 \\
\hline & Le Bluyais ? & Gironde & $9 \mid 0$ & {$[\because 1:$} & PWR & FRAM & (1) 8.3 \\
\hline & 1. Hlayuis 4 & Cirronds: & $9 ! 0$ & $1 \because 1:$ & PWR & FRAM & 198.3 \\
\hline & Nugeni sur Seine 1 & Aube & 1,110 & EI: & PWR & IRAAM & 1987 \\
\hline & Nogenl sur Seine? & Aube & 1.310 & III: & PWR & FRAM & 1988 \\
\hline & Puluel I & Seine. Muritime & 1.3 .31 & SEF: & I'WK & $I R A M$ & 1984 \\
\hline & Paluel 2 & Seine-Maritime & 1.130 & $1: 1:$ & l'WK & IRAM & 1984 \\
\hline & Palue:? & Seine.Murititrte & 1.3 .30 & El: & l'WR & FRAM & 1085 \\
\hline & Paluel it & Seinc-Maritime & $1,3.30$ & I:F: & lWW & IRAMI & $19 \times 6$ \\
\hline & Phenis & Giard & 2.3 .3 & EI: & I.MFHR & $(1) M$ & 1071 \\
\hline & St. Laurent Al & loir-et-cher & .390 & $E !:$ & (jOK & VAR & $19(19)$ \\
\hline & Si. laurent Az & 1,oltet-Cher & 450 & Eli & CICK & VAR & 1971 \\
\hline & St. 1.nurent B1 & lovir-et-cheer & 915 & E:I: & PIVR & IKAAM & 1981 \\
\hline & St. I.uurent 132 & lonir-et-cher & 880 & EY: & I'WR & IRAM & $|198|$ \\
\hline & Suint-Alban 1 & lsere & 1,315 & $1: F$ & PWR & $I R A M$ & 1085 \\
\hline & Saint-Alban 2 & Isere & 1,335 & $1: 1:$ & PWR & $\operatorname{IRAM}$ & 1086 \\
\hline & Trkastin 1 & Drome & 915 & $E F$ & PWR & IRAM & 11880 \\
\hline & Tricastin 2 & Drome & 915 & $\mathrm{El}$ & PW'R & IRAM & 10801 \\
\hline & Tricastin 3 & Drome & 015 & $\mathrm{EH}$ & PWR & IRAM & $|198|$ \\
\hline & Tricustin 4 & Drome: & $9 ! 5$ & $1: 1$ & I'WR & IRAM & 1981 \\
\hline 'lotul & 55 Units & & 52,588 & & & & \\
\hline \multirow{12}{*}{$\begin{array}{l}\text { Germany, Wost } \\
\text { (Federail } \\
\text { Republic } \\
\text { ol Ciermanys) }\end{array}$} & Mithls A & Worms/Rhein & 1,146 & RW & PWR & SIEM/KWU & 1974 \\
\hline & Miblis BS & Wormo/Rhein & 1,240 & RW & PWR & $S I I: M / K W I I$ & 1976 \\
\hline & Brokdout & Irrokikurt & 1,307 & RW & 'NWR & $S 1 I: M / K W W$ & 1986 \\
\hline & Hrunsbuertel & Brunsbuettel & 771 & $k(i$ & HWR & Al:Ci & 1977 \\
\hline & I:msland KKI: & l.inge'n & 1,242 & K.N & PWR & KWII & 1088 \\
\hline & Cirafenducinfeld $\mathrm{KKC}$ & Cindenrlowinfeld & 1,235 & MY' & l'WR & SII:MS/KWU! & l1182 \\
\hline & Grohude $\left(K W^{\prime}(i)\right.$ & Circhonde: & $1,3(x)$ & (ici & PWK & SIL:MS/KWU & 1984 \\
\hline & Ciundremmingeds 13 & Cinndremmingen & 1,240 & $\mathrm{KH}$ & $H W R$ & $S I l: M / K W ! 1$ & $19 \times 4$ \\
\hline & Cinndremmingen $C^{\circ}$ & Citudremsmingen & 1,246 & KH & $B W R$ & $\mathrm{SIISN} / \mathrm{KW} W$ & 11184 \\
\hline & Isar KKII & ()hu (lsar) & 870 & KI & $\| W^{\prime} R$ & SHI:MSKWII & 1977 \\
\hline & Isal KKI? & ()hu (Isar) & 1,285 & $\mathrm{kl}$ & HWH & SII:MS/KWU & lusk \\
\hline & Krotemund KKK & (icenturhl Kroummel & 1,260 & $\mathrm{kk}$ & HWR & Al: $;$ & 1981 \\
\hline
\end{tabular}

Sece ferenotes at end of hable. 
Table F1. Roster of Nuclear Generating Units Operable as of December 31, 1989, in Foreign Countries with FME (Continued)

\begin{tabular}{|c|c|c|c|c|c|c|c|}
\hline S'intully & l'mul Naume" & I. 112111111 & $\begin{array}{l}\text { (inpmelly" } \\
\text { (Not Miv') }\end{array}$ & llullyy' & 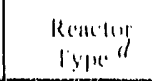 & 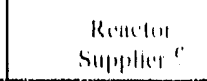 & 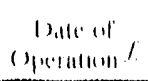 \\
\hline \multirow{10}{*}{ 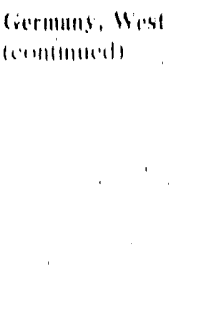 } & Mulluen-Kareluls & 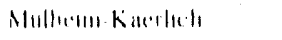 & $1,16.5$ & sith & I NIIIKR & IHN & 1186 \\
\hline & 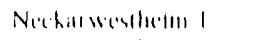 & Necharwestlectur & 715 & lik & INWK & $\because l l M S / K W 1$ & 1076 \\
\hline & Neckillweshlle'lin: : & Nechamweshlowin & 1,225 & $(i k$ & PWR & SHIMS/KWU & 1484 \\
\hline & 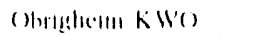 & ()higluentur & 1410 & $k()$ & PWR & SIll:M/KWU & 1068 \\
\hline & Nhilippoloutge KKl' & I'hilippishurge: & $x(14$ & $k l^{\prime}$ & HWV & $S 1 l: M / K W U$ & $10 \%$ \\
\hline & Philipmburg kkl : & Philippshuge: & $1,26,8$ & Kl' & איו'K & SIII:M/KWU & luxk \\
\hline & Stank KKS & Stuctio & $(1,4)$ & $k s$ & IWW & $S I l M / K W 11$ & 1472 \\
\hline & HIIK $\|(k)$ & Ilumm-Ventrul & $2(14$ & $11 \mathrm{~K}$ & HICik & $\|K\|$ & luss \\
\hline & IInterwersed & lisscolhannm! & $1.2,10$ & kil & PWR & SII:MS/KWU & 1178 \\
\hline & Willergassen (KWW) & 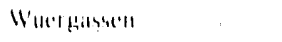 & $(0+4)$ & I'R & HWK & $A 1: C$ & 1971 \\
\hline Totul & 22 l/nits & & 22,6866 & & & & \\
\hline \multirow[t]{8}{*}{ Indlia } & Mulaus! & Kalpukkum, lamil Nudu & 220 & IA & IHWK & 1.1 & 108.3 \\
\hline & Mudias ? & kinlpukikum, Tamil Nulu & 221 & IA & l'HW'R & 1.1 & 198.5 \\
\hline & Narira 1 & 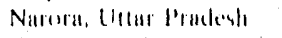 & 221 & 11 & l'HW'K & W'I. & (1) \\
\hline & Ra!iblhan I & Kinla, Rạasthau & 2117 & $\mathrm{IA}$ & l'IIW'R & ( ') ill: & $10 \%$ \\
\hline & Killiathan : & Kila, Ruminthan & 2117 & IA & I'HWW & 1.1 & 1080 \\
\hline & 1in prer 1 & Hinmbay & 10,11 & IA & HWR & $(i 1)$ & $19(1)$ \\
\hline & $1 n:, 4 n 12$ & Bumbay & 1.50 & IA & HWR & $(11)$ & $10(1)$ \\
\hline & 7 linits & & 1,374 & & & & \\
\hline \multirow[t]{3}{*}{ lluly: } & Citcrso!" & Cantsol, liancenza & $8 t_{11} 1$ & 11 & HWR & $A M /(H)=S()$ & 1078 \\
\hline & 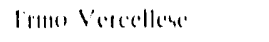 & Vuctelli & $2(11)$ & 11 & l'WR & W'LSI & $19(14$ \\
\hline & 21 inlts & & 1,120 & & & & \\
\hline \multirow[t]{39}{*}{ Jupan } & Fugen ATR & Tsurugia & $14 k$ & l': & IWCHWR & 1111 & 1078 \\
\hline & likushimu I anchi I & lukurhuma & 430 & I' & HW'R & (i): & 1970 \\
\hline & 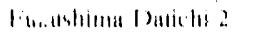 & lukushimia & $\%(1)$ & $11^{\prime}$ & HWR & (i): & 197.3 \\
\hline & 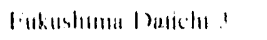 & Jukilulima & $\% 60$ & II & HWW & los & 1074 \\
\hline & fukmbhima 1)urichn 4 & Jukushimu & 7011 & $11{ }^{\prime}$ & WW'R & 1111 & 1478 \\
\hline & lukwhoma lsumbos & lukushima & $7(10$ & 11 & HWR & Tos & $107\rangle$ \\
\hline & Pukushuma l Juich! 6 & I.ukishima & 1,067 & 'T' & HWK. & (il: & 1974 \\
\hline & lukushuma |)แแแ 1 . & lukushima & 1,067 & 'T' & IIW'R & los & $|198|$ \\
\hline & Iukushumu Daun : & lukushuma & $1,(06,7$ & 'T' & HWR & 1111 & 119.1 \\
\hline & 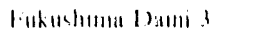 & linkushimu & $1,(16,7$ & $11^{\prime \prime}$ & IBWK & Tos & $110 x 4$ \\
\hline & Fuhusluma l Buni a & Prukushimat & $1,(1617$ & 'T' & HW'R & 1110 & $10 \times 7$ \\
\hline & (itonkall) & Gicolkai, Singa & 529 & $K Y$ & lWW & MHII & 1079 \\
\hline & Gisnkal ? & Ginkai, Singa & 529 & $k Y$ & PWR & MHII & 1981 \\
\hline & 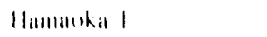 & Ilamanka-chu, shizunku & 515 & ( III & HWR & Tosi & 11775 \\
\hline & Mimminthil? & Mlumatikia-hor, Shoruriku & 815 & (H) & HWV & Tos & 1078 \\
\hline & Minmankia 1 & Humanoku-cho, Shounoka & 1,060 & C'II & HWR & Tos & lox? \\
\hline & ikula 1 & Ikula-chu, Ihume & 5.18 & Sil & PWR & MIII & 1977 \\
\hline & Ih.lla 2 & Ikala-chu, lihimse & 5.18 & $s i^{\prime}$ & PWR & MIII & $|98|$ \\
\hline & Kashiwasaks kiarian I & Nilgula & $1,(1) 67$ & 11 & HW'K & Tos & logs \\
\hline & Kanluwarakı Kantwas & Nilg;ala & $1.06,7$ & 111 & HW'R & 1111 & $10 x 9$ \\
\hline & Milnamiat I & Mhusma-cho & 321 & KA & PW'K & WI:SI & $107 \mid$ \\
\hline & Mhanmat:. & Milnatmalchor & 470 & KA & l'WR & MIII & $10 \% 2$ \\
\hline & Mihama 1 & Maltanialatho & 780 & kA & PWR & M111 & 1076 \\
\hline & ()tin 1 & (Hi-chu & 1.120 & KA & I'WK & WI:SI & 1017 \\
\hline & ( ) $\|_{11}:$ & ()hi-cho & 1,120 & $k \wedge$ & lWW & WI:ST & $14 \% 8$ \\
\hline & (magawal & ()shikitgunu & 407 & $1 \%$ & HWR & Ios & $110 x .1$ \\
\hline & Sendian 1 & Sendari, Kagendirma & 846 & K' & l'W'k & MIII & 1181 \\
\hline & Sconclial :' & Sonlin, Kagmhinsta & 846 & $k y^{\prime}$ & PWR & IIII & 11485 \\
\hline & Shimume 1 & Kushuma-dho, Shrmane & 419 & $i k$ & HWK & 1111 & ing. \\
\hline & Shomante? & Kinshumal- ho, Shumane & 701 & ( ' $\mathrm{k}$ & IHWR & MIII & $10 \times 8$ \\
\hline & Takahaman I & liakahama-chu, & $7 k 0$ & $k \wedge$ & l'W'R & WI:SI & $|117|$ \\
\hline & Takiahama? & I akahatuma-chu & 7801 & $k \wedge$ & PWik & MIII & 1075 \\
\hline & lakahlatma! & Tilkahtama-chn & 8.10 & $k A$ & PWK & MIIII & $19 \times 4$ \\
\hline & Iatcathamial of & Tukahumatcher & 830 & KA & I'WK & MIII & 108.1 \\
\hline & $|0 k, \ldots| \mid$ & linkit Mura & 124 & ני & (ick & (ilic & 196.5 \\
\hline & likw ? & lokin Mura & 1.050 & .111 & HW'R & (if: & $111 \%$ \\
\hline & |nman| & Inlltant Ilukkander & 550 & $111)$ & I'W'R & NIII & laxk \\
\hline & 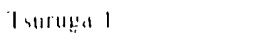 & Thtrullgit & 1.41 & Il' & IIWK & $(i):$ & $14(1)$ \\
\hline & 1,4rum:? ? & 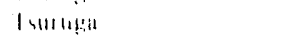 & 1,115 & 11 & IIW'R & $\mathrm{N} 11 \mathrm{I}$ & loxiso \\
\hline Iutul & 30 Units & & $29,26,5$ & & & & \\
\hline
\end{tabular}


Table F1. Roster of Nuclear Generating Units Operable as of December 31, 1989, in Foreign Countries with FME (Continued)

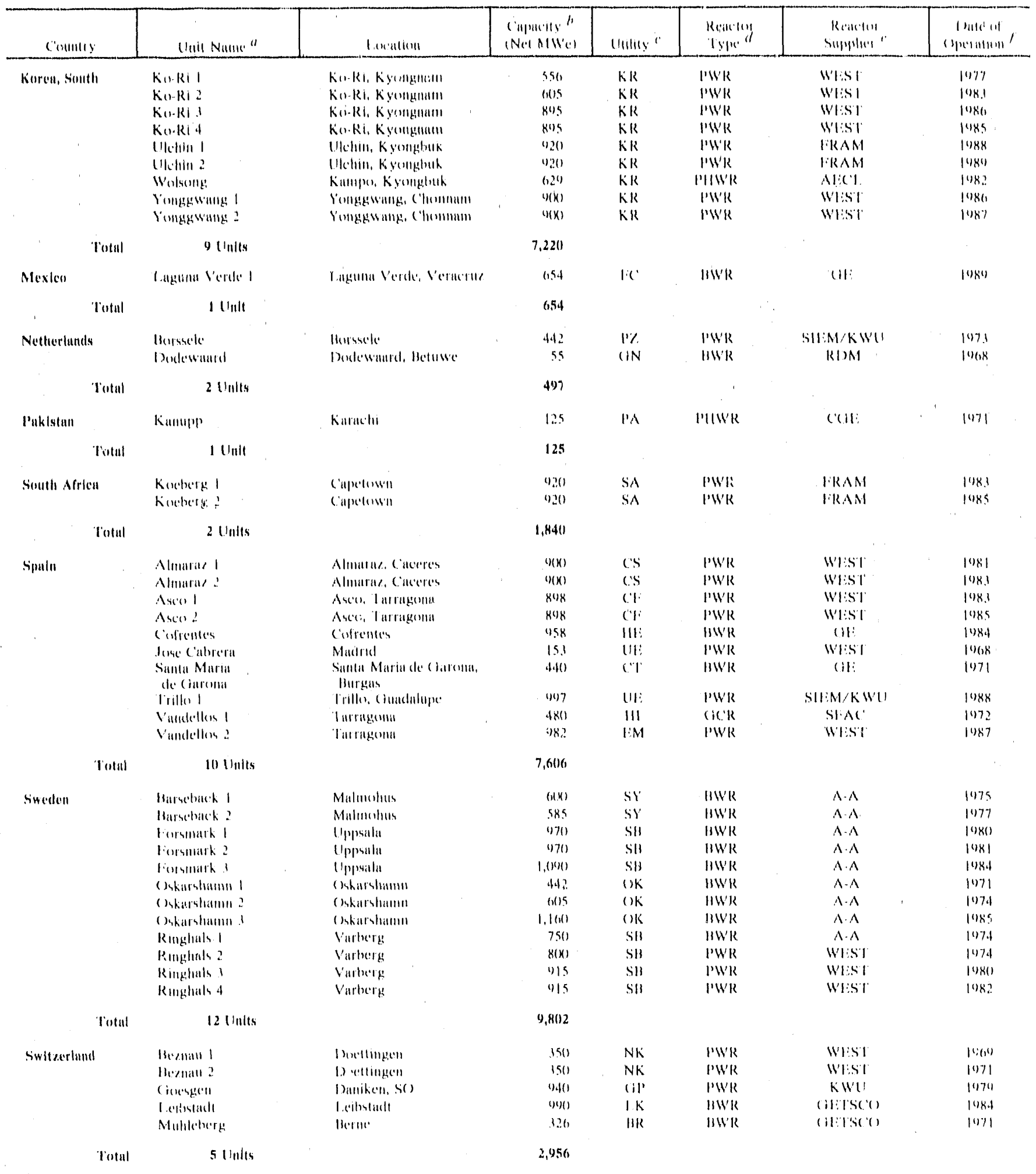

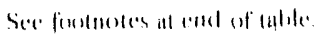


Table F1. Roster of Nuclear Generating Units Operable as of December 31, 1989, in Foreign Countries with FME (Continued)

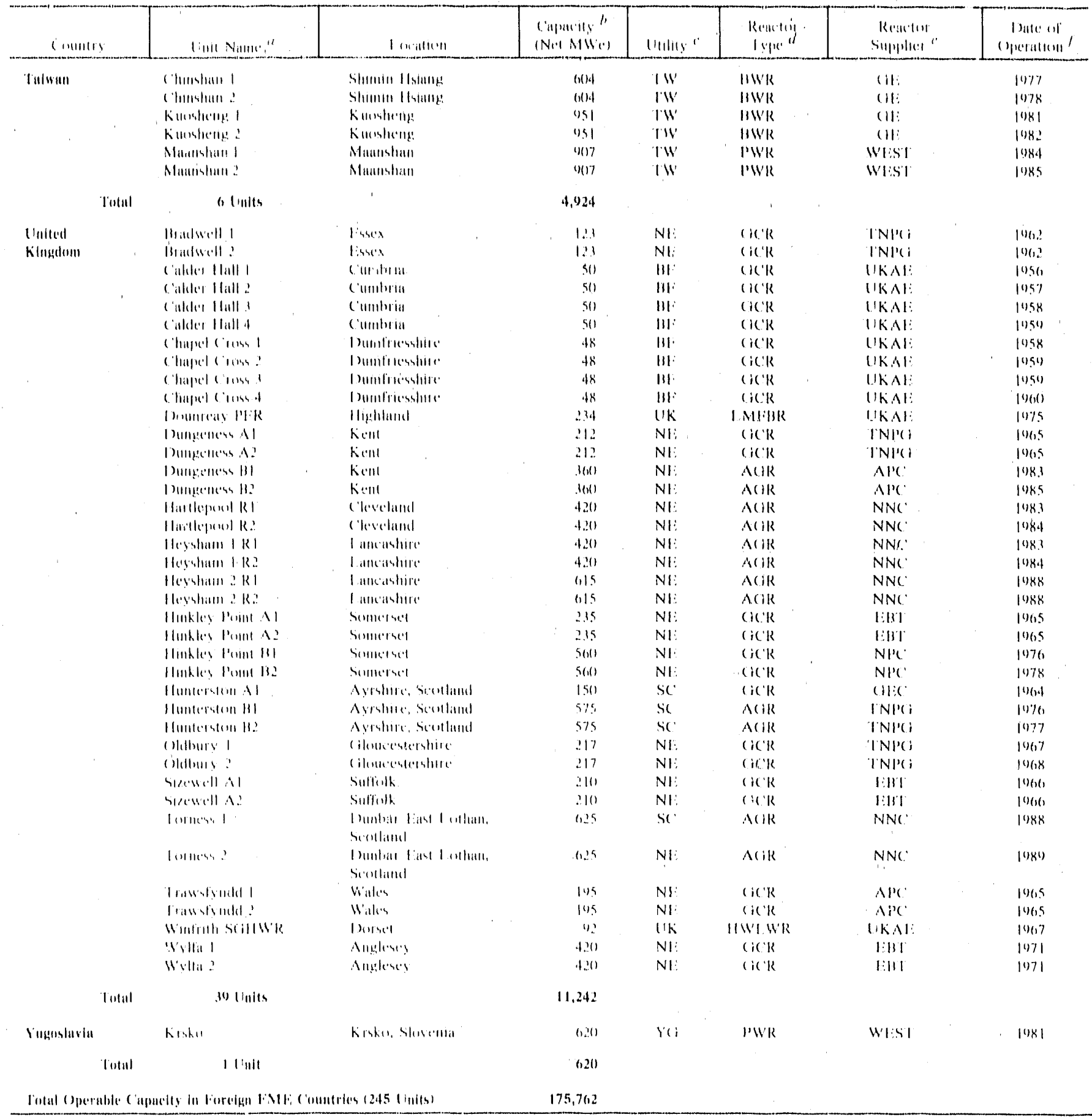

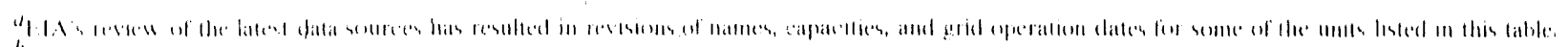

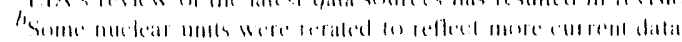

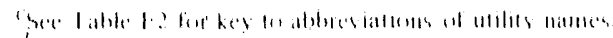

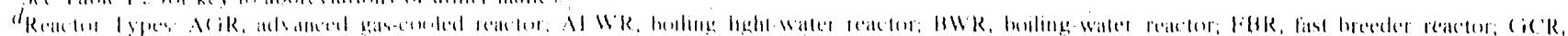

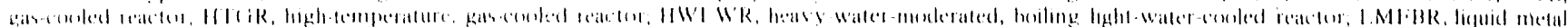

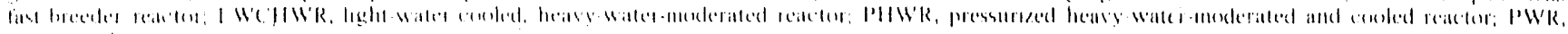

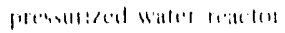

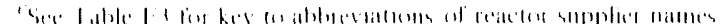

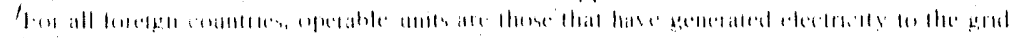

"I he (

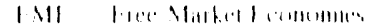

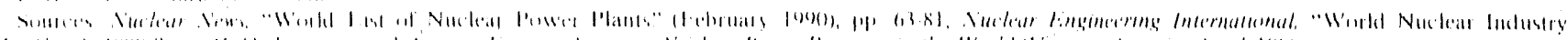

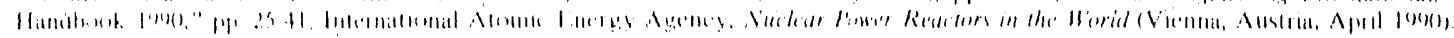


Table F2. Key to Utility Codes for Rosters of Foreign FME Commercial Nuclear Generating Unics

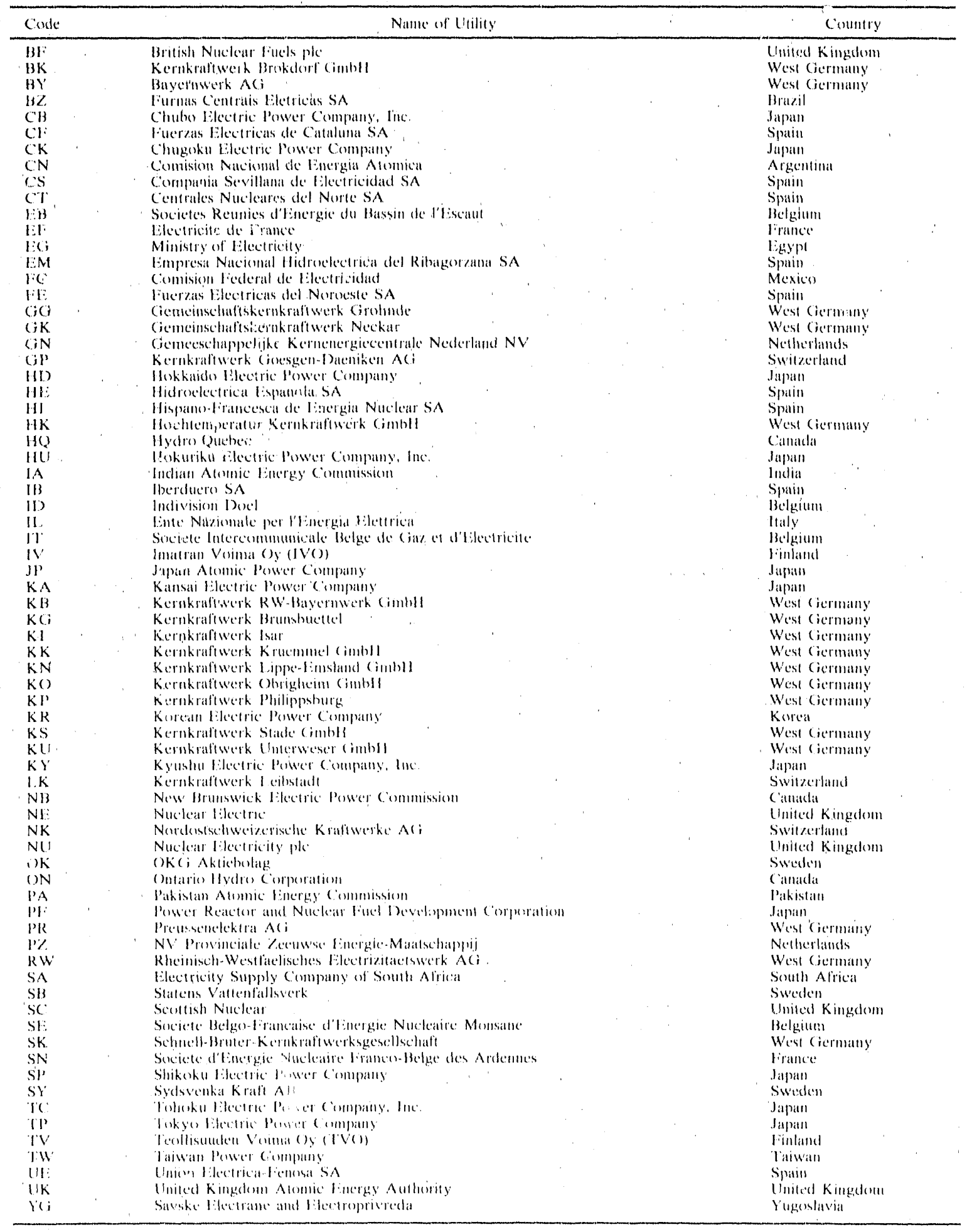


Table F3. Key to Reactor Supplier Codes for Rosters of Foreign FME Commercial Nuclear Generating Units

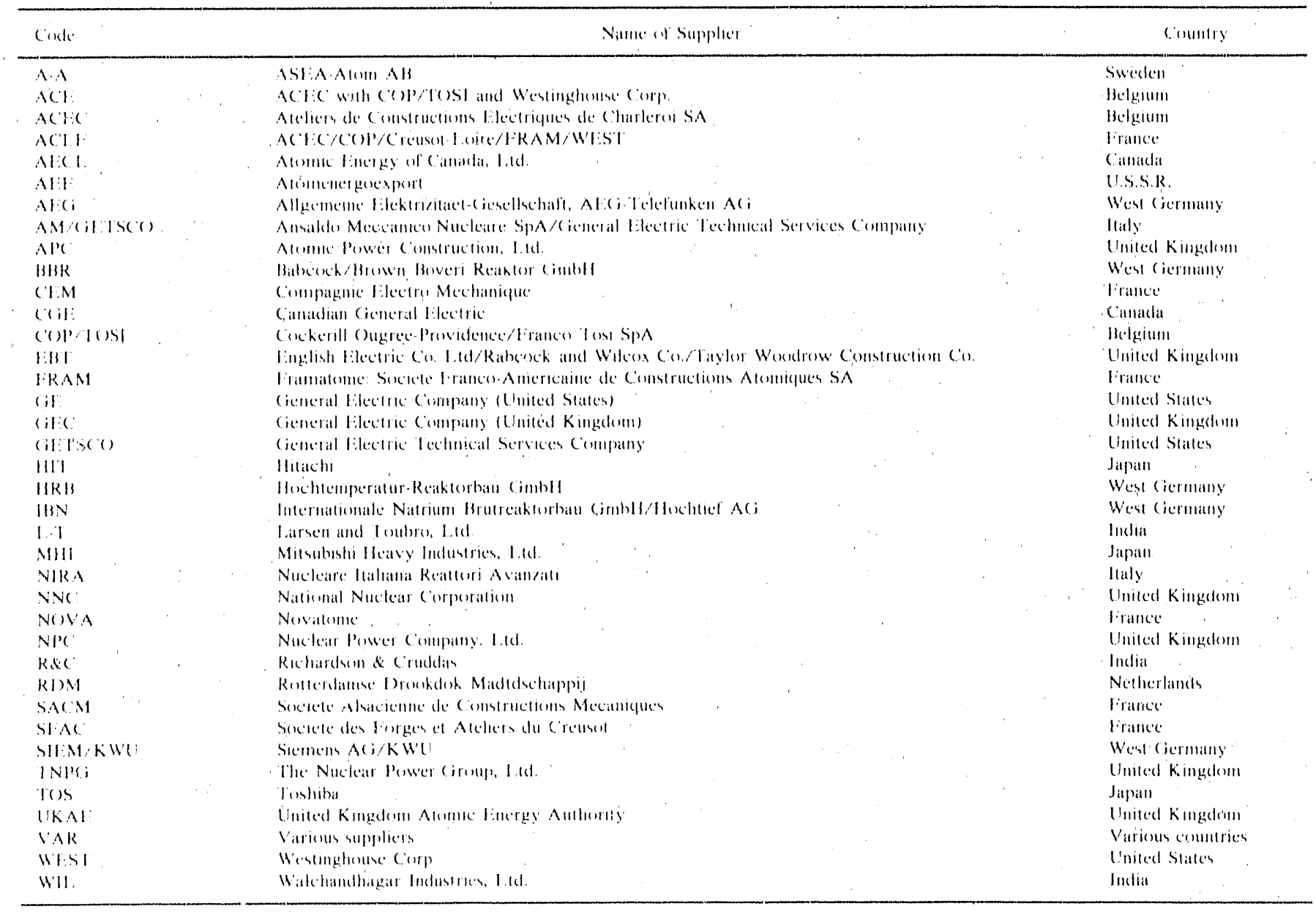




\section{Appendix G}

Foreign FME

Nuclear

Generating Units

in the

Construction

Pipeline as of

December 31, 1989 


\section{Foreign FME Nuclear Generating Units in the Construction Pipeline as of December 31, 1989}

Table G1. Roster of Nuclear Generating Units in the Construction Plpeline as of December 31, 1989, in For zign Countiries with FME

\begin{tabular}{|c|c|c|c|c|c|c|c|c|c|c|}
\hline \multirow[b]{3}{*}{ Conntrs } & \multirow[b]{3}{*}{ l'mu Pvink " } & \multirow[b]{3}{*}{ 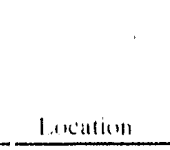 } & \multirow{3}{*}{$\begin{array}{c}\text { (apanity } \\
\text { (Net } \\
\text { MHes) }\end{array}$} & \multirow[b]{3}{*}{ Ulility" } & \multirow[b]{3}{*}{ lype } & \multirow[b]{3}{*}{$\begin{array}{l}\text { Renetor } \\
\text { Supplier : }\end{array}$} & \multirow{3}{*}{$\begin{array}{l}1 \% \\
\text { coin. } \\
\text { plete } \\
\end{array}$} & \multicolumn{3}{|c|}{ Expected Dute of Operution } \\
\hline & & & & & & & & \multirow[b]{2}{*}{ Publislied $f$} & \multicolumn{2}{|c|}{ lis } \\
\hline & & & & & & & & & $1 . k$ & UK \\
\hline Argentinu & Alucha : & $\begin{array}{l}\text { I.ma, Bucmos } \\
\text { Arres }\end{array}$ & $(19) 2$ & $(\mathrm{~N}$ & PHWK & $\begin{array}{l}\text { Sll:ul/ } \\
\text { KWu }\end{array}$ & 66 & $h_{0 / 144}$. & $2(K \times)$ & 1945 \\
\hline Total & I lnit & $\ddots$ & 692 & & & & & & & \\
\hline \multirow[t]{2}{*}{ Brazil } & Antral ? & Itau) & 1.226 & $13 \%$ & PWR & $\begin{array}{l}\text { Sll:M/ } \\
\text { KWU }\end{array}$ & (1) & $112 / 94$ & $2(x)$ & 1095 \\
\hline & An!!!1! & Itandina & $1,2,11$ & $13 \%$ & PWR & $\begin{array}{l}\text { SIl:M/ } \\
\text { killi }\end{array}$ & 28 & $4: 3 / 47$ & $2(x) .5$ & $2(K K)$ \\
\hline Intul & 2 lnits & & $2,45 x$ & & & & & & & \\
\hline \multirow[t]{4}{*}{ C'anada } & 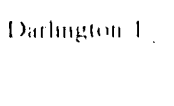 & 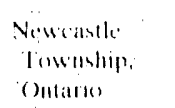 & 881 & (IN & PIIWR & AICL & 96 & $h_{12 / 9)}$ & 1009 & $\ln (90)$ \\
\hline & Datlughtum 2 & $\begin{array}{l}\text { Newconste } \\
\text { lowmship) }\end{array}$ & KBI & $1) \mathrm{N}$ & WWW & Al'C'1. & .99 & $\left.h_{2 / 0}\right)$ & 1000 & 1900 \\
\hline & 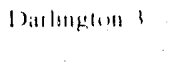 & $\begin{array}{l}\text { Newcaslle: } \\
\text { limushlip: }\end{array}$ & 881 & $\operatorname{Con}$ & PIWR & Al:CI & 75 & $h_{12 / 01}$ & 1045 & 1005 \\
\hline & 1)arlmalon 4 & $\begin{array}{l}\text { Noweaslle } \\
\text { lowmslal }\end{array}$ & 881 & $(1 \mathrm{~N}$ & PIIWR & $A I: C 1$ & 45 & $h_{12} / 92$ & 1905 & $1(x) 5$ \\
\hline Totul & 41 inits & & 3,524 & & & & & & & \\
\hline Figypt & $\begin{array}{l}\text { A.1) Dabiat I } \\
\text { (11) Ithatia? }\end{array}$ & $\begin{array}{l}\text { 1:(1-1) ithilat } \\
1:(-1)_{\text {ithital }}\end{array}$ & $\begin{array}{l}9(x) \\
y(k)\end{array}$ & $\begin{array}{l}1:(; \\
1: C ;\end{array}$ & $\begin{array}{l}\text { PWR } \\
\text { PWR }\end{array}$ & $\begin{array}{l}\mathrm{NA} \\
\mathrm{NA}\end{array}$ & $\begin{array}{l}0 \\
0\end{array}$ & $\begin{array}{l}\text { NA } \\
\text { NA }\end{array}$ & $\begin{array}{l}2020 \\
\ldots\end{array}$ & $\begin{array}{l}20101 \\
20120\end{array}$ \\
\hline lintal & 2 lenits & & 1,800 & & & & & & & \\
\hline \multirow[t]{9}{*}{ Prance } & Cintleי16) ? & Minelly: & $\therefore .3(x)$ & $1: \mathrm{F}$ & IWW & IRAM & 94 & $i_{2} / 9()$ & (1) & $100(0)$ \\
\hline & (allement 4 & Muselle. & $1.3(k)$ & $1: 1:$ & I'WR & IRAM & 81 & $h_{(6 / 4)}$ & 1900 & 1900 \\
\hline & $(\mid h+6)|B|$ & Ardemeses & 1.455 & $1: 1:$ & l'WK & IRAM & 7() & $h(0 / 1) 2$ & 1405 & 19015 \\
\hline & (.thun 132 & Arilemes & 1,455 & $1: 1:$ & l'Wh & VRAM & 51 & $h_{1}(1) / 93$ & $2(x)$ & 1945 \\
\hline & ( Natux I & Vін'וाা" & $1,45,5$ & $1: 1:$ & l'W'R & $F R A M$ & 11 & $14 / 96$ & $20 \times 15$ & $2(k x)$ \\
\hline & Cinlfech 1 & $\begin{array}{l}\text { larn al } \\
\text { ciarrmme }\end{array}$ & 1,310 & $1: 1:$ & l'WR & JRAM & (1) & $i_{2}, 00$ & 1995 & 1095 \\
\hline & Giallech? & $\begin{array}{l}\text { larn cet } \\
\text { fiarnulu }\end{array}$ & 1.310 & $1: \mathrm{H}$ & l'WR & $\mid K A A M$ & 60 & $\left.h_{S}, 1,\right\}$ & 1005 & 19095 \\
\hline & Pinley 1 & $\begin{array}{l}\text { Sxille } \\
\text { Marstume }\end{array}$ & .130 & $1: 1$ & PWR & IVRAM & 94 & $i_{2 / 4)}$ & $100(1$ & $1(x) 0$ \\
\hline & 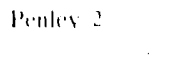 & $\begin{array}{l}\text { Sulle. } \\
\text { Matrimete }\end{array}$ & $1,1,30$ & $1: 1:$ & PWR & HRAM & 70 & $h_{3 / 9 ?}$ ? & 1)(1) & 190,5 \\
\hline Toful & 9 l'nits & & 12,245 & & & & & & & \\
\hline
\end{tabular}


Table G1. Roster of Nuclear Generating Units in the Construction Pipeline as of December 31, 1989, in Foreign Countries with FME (Continued)

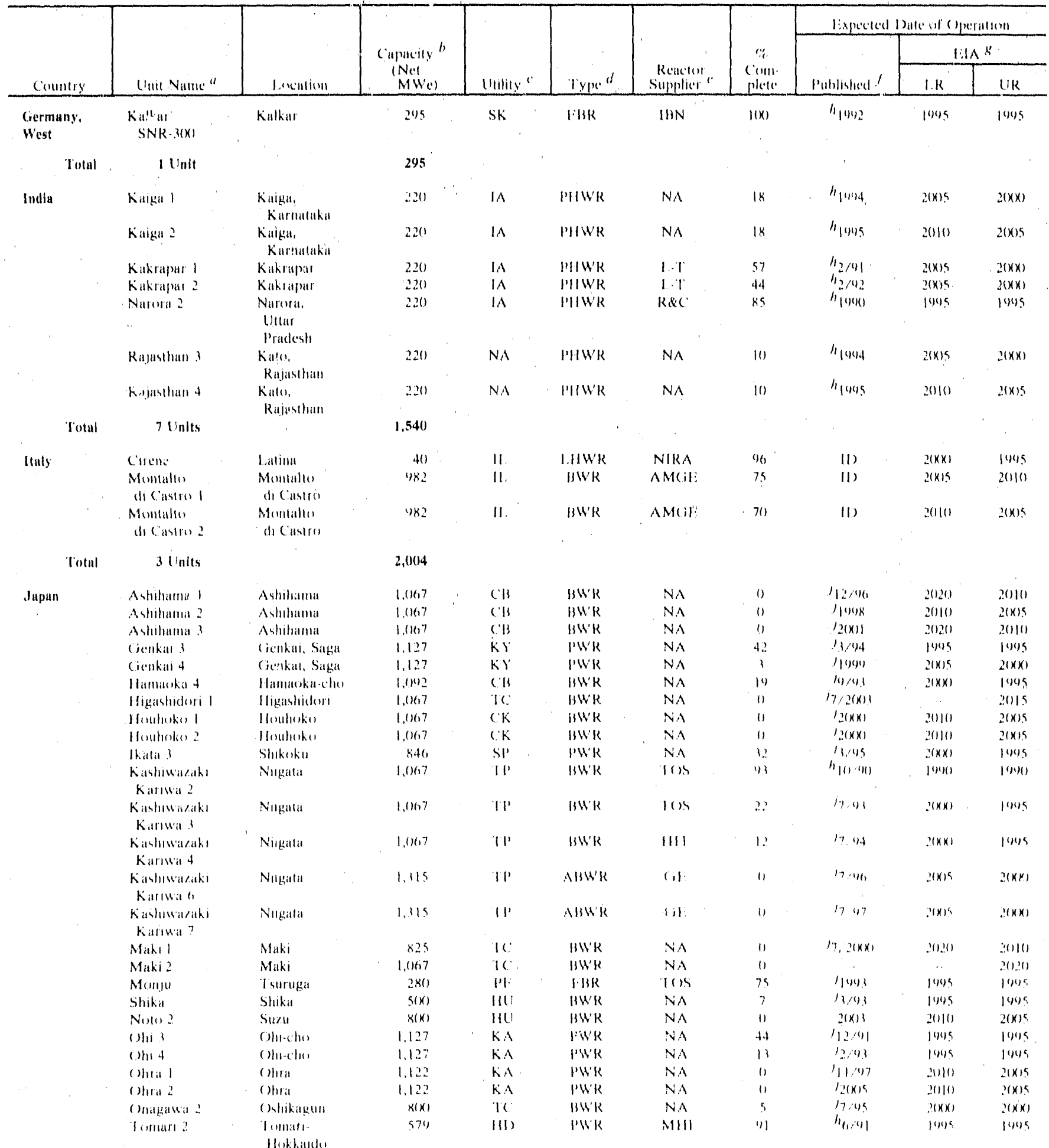


Table G1. Roster of Nuclear Genersiting Units in the Construction Pipeline as of December 31, 1989, in Foreign Countries with FME (Continued)

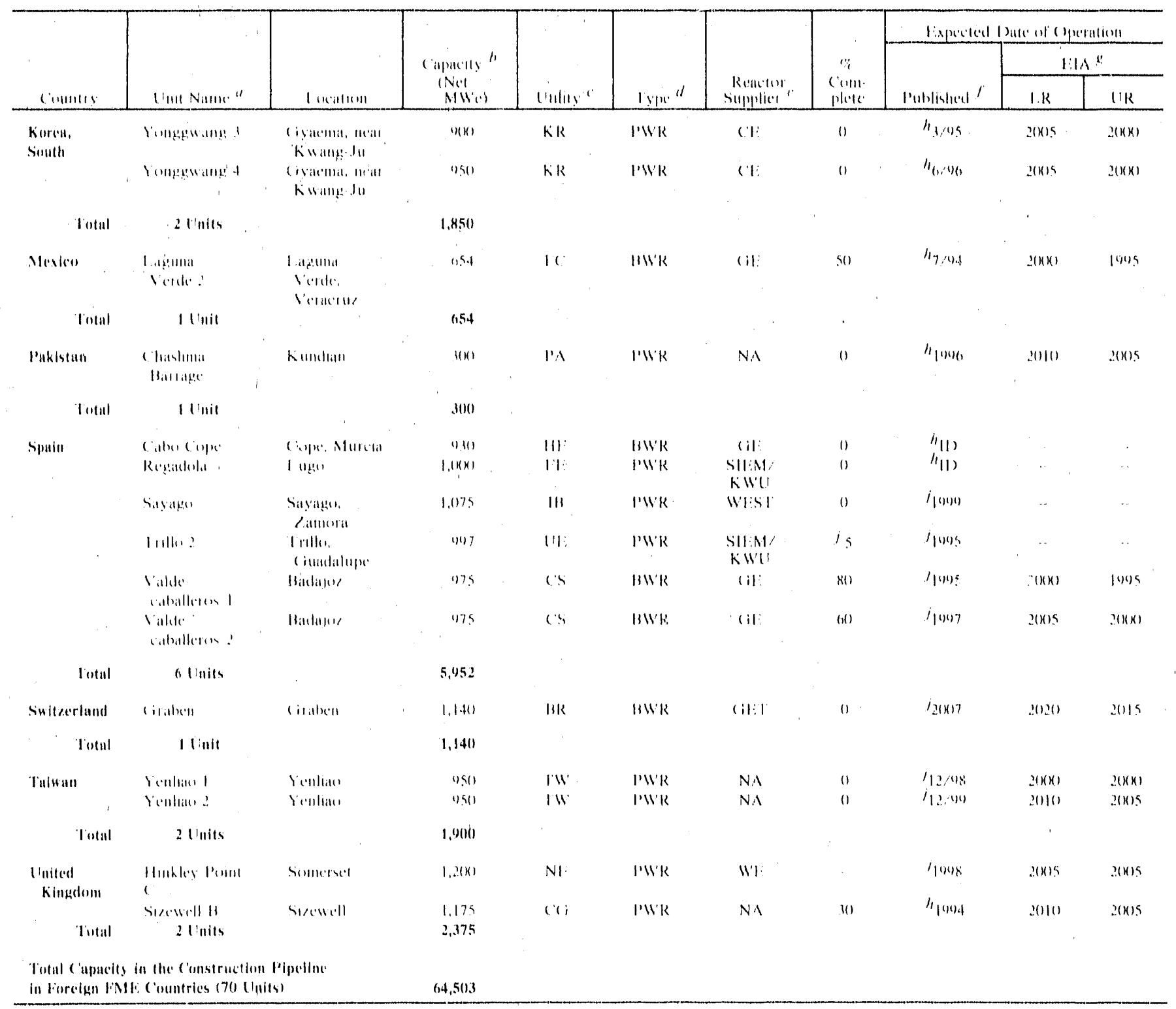

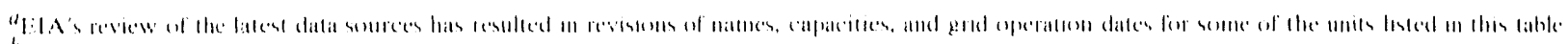

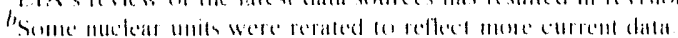

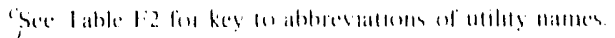

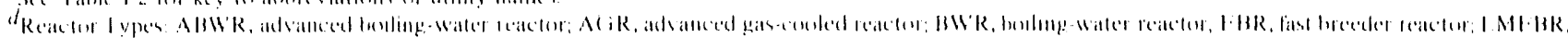

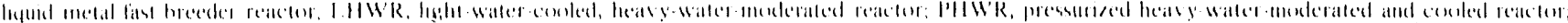

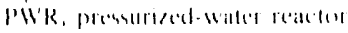

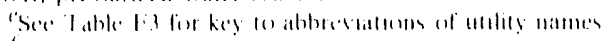

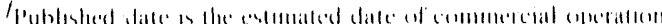

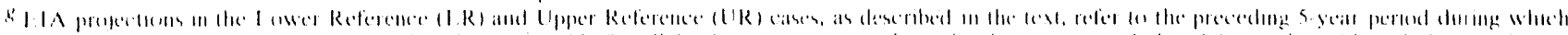

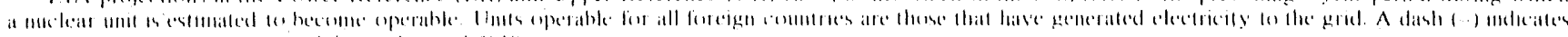

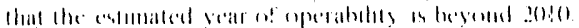

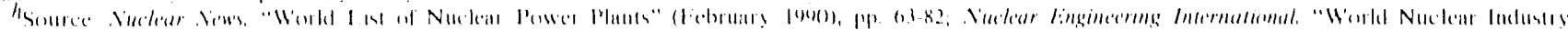

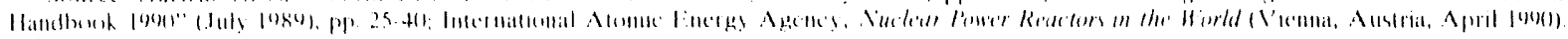

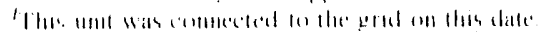

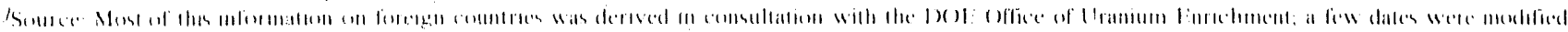
hy $1: 11$

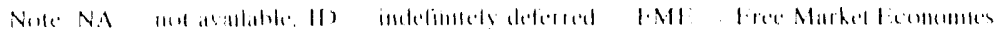




\section{Table G2. Final Periods of Pipeline Projections for Installed Nuclear Capacity in Foreign FME Countries}

\begin{tabular}{|c|c|c|}
\hline \multirow[b]{2}{*}{ Country } & \multicolumn{2}{|c|}{ Final Perlod of Plpoline Projection } \\
\hline & $\begin{array}{c}\text { Lower Rolorenco } \\
\text { Case }\end{array}$ & $\begin{array}{c}\text { Uppor Pelorence } \\
\text { Case. }\end{array}$ \\
\hline \multicolumn{3}{|l|}{ OECD Countries } \\
\hline 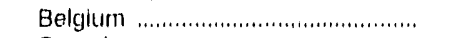 & 2010 & 2005 \\
\hline 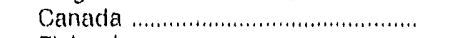 & 2000 & 1905 \\
\hline 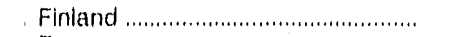 & 2005 & 2000 \\
\hline France & 2010 & 2010 \\
\hline 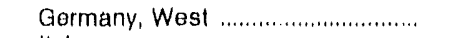 & 2010 & 2005 \\
\hline 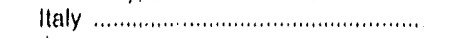 & 2010 & 2005 \\
\hline 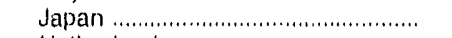 & 2015 & 2015 \\
\hline 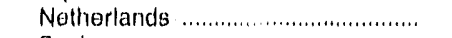 & 2006 & 2000 \\
\hline Spain ............................................... & 2005 & 2000 \\
\hline Swoden ......................................., & 2020 & 2015 \\
\hline Switzerland .................................. & 2010 & 2005 \\
\hline 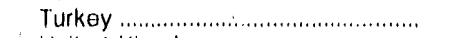 & 2015 & 2000 \\
\hline Unitod Kingdom ............................ & 2010 & 2005 \\
\hline \multicolumn{3}{|l|}{ Non-OECD Countrles } \\
\hline 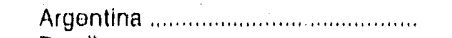 & 2010 & 2005 \\
\hline 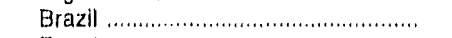 & 2015 & 2010 \\
\hline 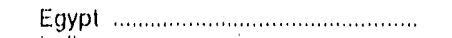 & 2015 & 2015 \\
\hline 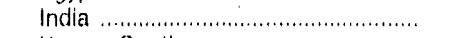 & 2005 & 2005 \\
\hline 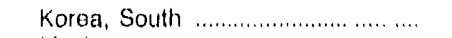 & 2005. & 2005 \\
\hline 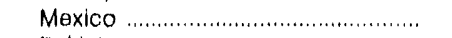 & 2015 & 2010 \\
\hline 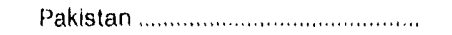 & 2010 & 2005 \\
\hline 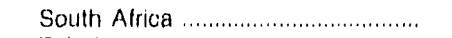 & 2010 & 2005 \\
\hline 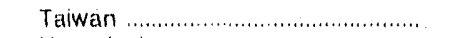 & 2005 & 2000 \\
\hline 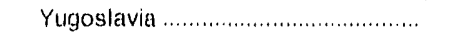 & 2010 & 2005 \\
\hline
\end{tabular}




\section{Appendix $\mathrm{H}$}

Foreign Nuclear Generating Units Operable as of December 31, 1989 in Countries with Regulated Market and Centrally Planned Economies 


\section{Foreign Nuclear Generating Units Operable as of December 31, 1989 in Countries with Regulated Market and Centrally Planned Economies}

Table H1. Roster of Foreign Nuclear Generating Units Operable as of December 31, 1989, in Countries with Regulated Market and Centrally Planned Economies

\begin{tabular}{|c|c|c|c|c|c|c|c|}
\hline limmln & I/111 Nam." & l. 18011611 & $\begin{array}{l}\text { (ilnacily" } \\
\text { (Nit Millo) }\end{array}$ & 'Mility" & $\begin{array}{l}\text { Ramelur } \\
\text { lype }\end{array}$ & $\begin{array}{l}\text { Renctur } \\
\text { Sulpticer }\end{array}$ & $\begin{array}{c}\text { linte al } \\
\text { ()purationt }\end{array}$ \\
\hline \multirow[t]{5}{*}{ Hulgaria } & kinlunlus I & kouluduy & 418 & 1:1: & PWR & AI:I: & 1674 \\
\hline & kuluduy ? & kudinluy & d11s & 11 & PW'K & Al:I: & 1075 \\
\hline & kinstraluy 1 & Kindicluis & 408 & $1 \because 1:$ & I'W'R & NI:I: & 1480 \\
\hline & Korlanduy a & kirdlucluy & 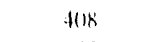 & $1: 1 \vdots$ & lWWR & NAI: & luk: \\
\hline & kinlenlins 9 & Kinludily & 1953 & $1: 1$ & l'WR & Ali: & 1017 \\
\hline Tulul & 5 linits & & 2,585 & & & & \\
\hline \multirow{8}{*}{ 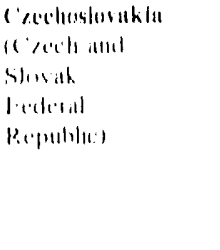 } & Huhumке I & 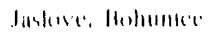 & 4108 & $(\%$ & l'W'R & Al:I: & $107 x$ \\
\hline & Mrohunices: & 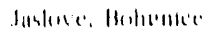 & 4018 & $(\%$ & PW'R & Al:I: & (1) \\
\hline & Muhumere & 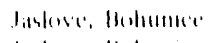 & 4118 & $(\%$ & PWR & NI:1: & 1984 \\
\hline & Hehumber 4 & Intare, Hohmenter & 4118 & $1 \%$ & l'Wk & Al:I: & 1985 \\
\hline & Dobnowans I & Wuhnomy & $4(1 k$ & $(\%$ & PW'R & Al:1: & $10 \times 5$ \\
\hline & I) Jhesiatsy : & Duhenally & $4(16$ & $6 \%$ & l'Wk & Al: & 1980 \\
\hline & | Muturallus 1 & Duknsuly & 401 : & $(1)$ & I'W/R & Al:I: & 1986 \\
\hline & 1)uknowalls + & Inthovally & $40 x$ & $(\%)$ & PW'K & Al:1: & $10 \times 7$ \\
\hline $1 \|+u 1$ & 8 linits & & 3,264 & & & & \\
\hline \multirow{6}{*}{ 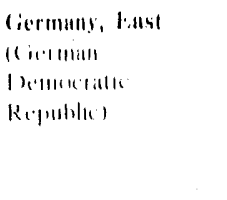 } & Nond I & I เม็นเแแ & 4118 & $1 x_{i}$ & IWR & Al:I: & 1971 \\
\hline & ivinul: & | $111\|1\| 1$ & $40 x$ & $1)(i$ & I'WR & Al: & $11 \% \%$ \\
\hline & Vinil 1 & I $11,\|u\| n$ & $411 k$ & $13 i$ & I'WR & Al: : & 1077 \\
\hline & Nurd a & I "1hunu" & $4(1)$ & $1) i$ & P'W'R & Al: & $\mid 177$ \\
\hline & Nond is & I "uhmun & $.110 \mathrm{~s}$ & $1): i$ & IW'K & Al: & 1080 \\
\hline & Rherminele! & 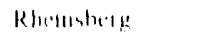 & $6 . !$ & $f x i$ & PW'R & 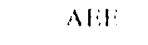 & 10616 \\
\hline Tintul & G l'nits & & 2,1112 & & & & \\
\hline \multirow[t]{4}{*}{ Ilwagary } & Hisk, I & linkis & 4111 & $11 N$ & I'W'R & Al: & lex: \\
\hline & l'uts.? & l'ukis & 419 & $11 N$ & l'WR & AI:I: & 11184 \\
\hline & l'ake, 1 & l'aks & 410 & $11 N$ & I'W'R & Al: & $16 \times 6$ \\
\hline & l'ultind & P'ith, & 4111 & IIN & INW & Al: & $108 \%$ \\
\hline T'utul & 4 linils & & $1,64,5$ & & & & \\
\hline \multirow{9}{*}{ 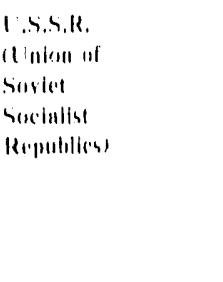 } & |latlition, | & Mallaknon & 11511 & $11 k$ & PWR & Al:I: & $10 \times 5$ \\
\hline & Matabroma! & Halluhwor & 11511 & IIR & IW'K & $A I I$ & $\mid 48 \%$ \\
\hline & Malatinan & |Hatlathn| & 1951 & $1 / k$ & l'W'R & NIt: & $1118 x$ \\
\hline & Mhluriatut. ? & Siverallower. & 1.11. & $I ! K$ & lik & $N 11$ & $\mid 111,9$ \\
\hline & Whorgante 1 & Siverdlesest & $5 n(1)$ & UK & like & A 1 & $14 \times 61$ \\
\hline & $\left.\operatorname{lin} \mid \mathrm{s}_{0}\right)$ & Shav whenk.11 & 114 & I'R & $1: \| k$ & $\Delta 11$ & 1011 \\
\hline & cturemilyl & Ku & $11: 4$ & $1 / R$ & I (iR & AlI & 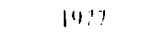 \\
\hline & ( larominl !' & Kin & $11: 5$ & I:R & I $H K$ & $A 1:$ & 1978 \\
\hline & Clanmbind 1 & KMי & $11 ! 5$ & lik & I GiR & AII & $|3 \times|$ \\
\hline
\end{tabular}


Table H1. Roster of Foreign Nuclear Generating Units Operable as of December 31 , 1989, in Countries with Regulated Market and Centrally Planned Economies (Continued)

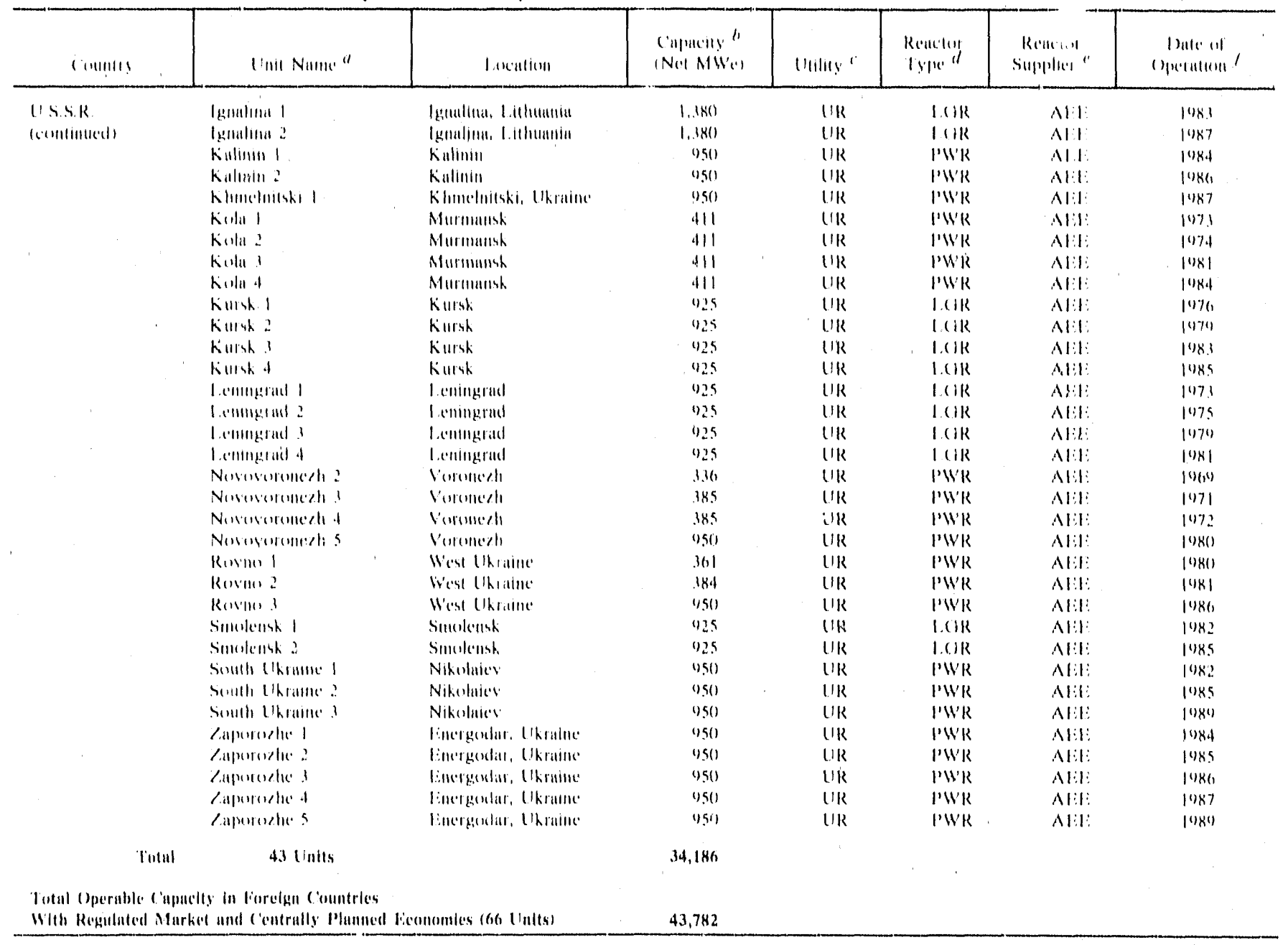

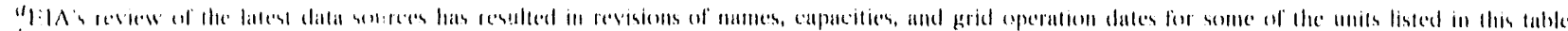

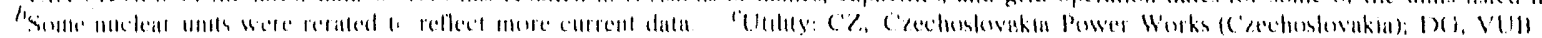

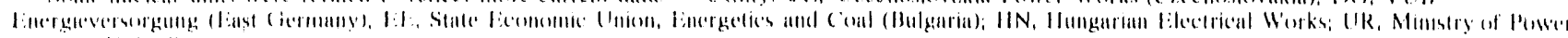
Stattum (lISSSR.

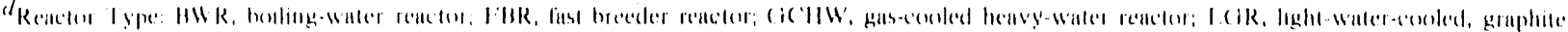

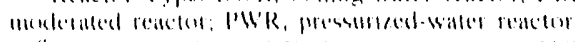

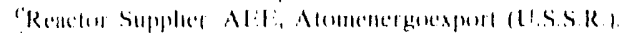

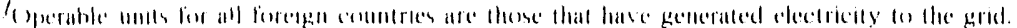

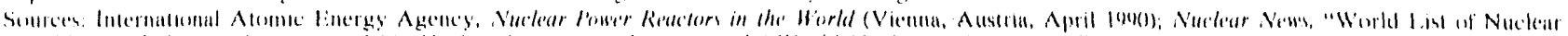

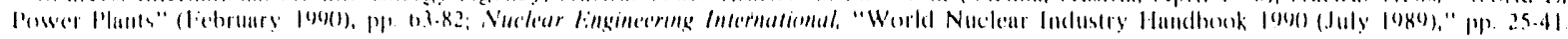


Table H2. Roster of Foreign Nuclear Generating Units in the Construction Pipeline as of Decernber 31, 1989, in Countries with Regulated Market and Centrally Planned Economies

\begin{tabular}{|c|c|c|c|c|c|c|c|c|}
\hline (inumlly & IIIII NiIIII" "l & I. Mentiun & $\begin{array}{l}\text { ('upulity " } \\
\text { (Not Mille) }\end{array}$ & linlity " & $\begin{array}{l}\text { Reacluy } \\
\text { Type }\end{array}$ & $\begin{array}{l}\text { Resclu" } \\
\text { Suppliket" }\end{array}$ & $\begin{array}{l}\text { lencerent } \\
\text { Lintipletes }\end{array}$ & $\begin{array}{l}\text { Published } \\
\text { Dale al } \\
\text { ()pration }\end{array}$ \\
\hline \multirow[t]{5}{*}{ IBulsuriu } & Helente I & Heleme & 115.1 & $1 \vdots 1 \vdots$ & l'W'k & Al:L: & .. & 1942 \\
\hline & Heleme : & Heleme & $19 \varsigma .1$ & $1 \vdots 1:$ & PIVK & Al:1: & . & |ini| \\
\hline & Heleme 1 & llelene: & 115,1 & $1: 1:$ & PW'R & Al: & .. & $\cdot \cdot$ \\
\hline & Henene + & Hulene & $0,5.1$ & $|:| \vdots$ & I'W'R & Al:1: & & .. \\
\hline & Kinlinlus & kin/luduy & 195.1 & $1: 1:$ & filk & Alit: & & 14101 \\
\hline . lulul & $5|\ln | 14$ & & $4,76,5$ & & & & & ' \\
\hline \multirow[t]{9}{*}{ C'llinu } & (inungulloing 1 & Duỵu Huy & 4.101 & Ro: & l'b'k & $I R A M$ & 410 & $1(1,11)$ \\
\hline & Cinangderigg : & 1) ny? Hiny & 0,310 & $R C^{\circ}$ & IIWR & $\mid R A M$ & .111 & 7113 \\
\hline & () Inshun I & Slumphini & 288 & $R C^{\prime}$ & I'W'R & NA & (1) & $12 / 011$ \\
\hline & QMmbhun ? & Shanghai & $(1)$ & RC: & I'W'R & $\mathrm{N} \wedge$ & & \\
\hline & (Q)inshun 1 & Shunghui & $n(x)$ & $R C^{\prime}$ & I'WR & NA & .. & \\
\hline & North limbl Chima I & Nontheasl chlilla & "(k) & $R C$ & I'WER & NA & - & (i) \\
\hline & North last Chilum 2 & 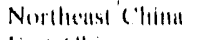 & $y(k)$ & $\mathrm{KC}$ & I'W'R & $N A$ & .. & 111 \\
\hline & SutnuI 1 & linsl C'limu & $n(k)$ & RC & l'WR & NA &.. & (1) \\
\hline & Simnun . & lianl C'limi & $y(x)$ & $R C^{\circ}$ & PWK & NA & .. & 117 \\
\hline ' lintul & 9 linlls & & 0,948 & & & & & \\
\hline \multirow[t]{3}{*}{ C 'ubu } & 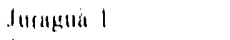 & C'confluegors & 408 & $(1)$ & l'WK & Al:L: & .. & (19)! \\
\hline & Jแ⿰แ⿻上แแ & clemlinegus & $4(1)$ & ( 11 & I'W'K & Al:i: & .. & . \\
\hline & $2\left|\|_{11}\right| t s$ & & H16 & & & & & \\
\hline \multirow{8}{*}{ 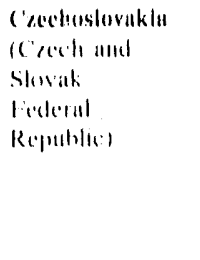 } & Muchense & Murhaser & 188 & $(\%$ & I'WR & Alit: &.. & [11)? \\
\hline & Muchusere & Mluhesere & .388 & $(\%$ & live & Al:l: &.. & \\
\hline & Mexherser 3 & Muchoures & 388 & $(\%$ & l'WK & Al:!: & .. &.. \\
\hline & Mardescer + & Mnchusec & .188 & $(\%$ & I'N'K & Al:1: & $\cdot \cdot$ & \\
\hline & Tamelin 1 & Femelin & 802 & $(\%$ & PWK & Al: &.$\cdot$ & $\| 112$ \\
\hline & linlluthin? & Temelin & $8(1) 2$ & $(\%)$ & I'WR & Al:I: & .. & $6 / 4$ \\
\hline & limelen! & lemelin & $81) ?$ & $(\%)$ & PWW & Al:1: & .. & 11,05 \\
\hline & Temeline 4 & lentrelin & 802 & ( $\%$ & IWR & Ali: & .. & $6 / 117$ \\
\hline 'tutul & $8 \mid \operatorname{lnll}$ & & 5,120 & & & & & \\
\hline \multirow{2}{*}{ 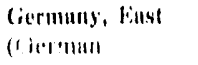 } & Stenulal 1 & Maz,achurg & $y(x)$ & $1)(1$ & PWK & Al:I: &.. & $|(1)| 2$ \\
\hline & Slendal: & Maggleburgh & $y(x)$ & $1)(1$ & PWK & Al:I: &.$\cdot$ & $13(1) 4$ \\
\hline 1)emorerula: & Slendelal 1 & Nuggdebures & $y(x)$ & 101 & I'WR & Ali: &.. & (1) \\
\hline \multirow[t]{5}{*}{ Republac) } & Stendal 1 & Mugeldehurg & $4(x)$ & 100 & l'WR & Al:I: &.. & (1) \\
\hline & Silcullal 5 & Mugdeburg! & $4(x)$ & $13 i$ & PWK & Alit: &.$\cdot$ & (1) \\
\hline & Stumlal 6 & Magdloug! & $n(x)$ & $1 x ;$ & PWR & Al: & $\cdot \cdot$ & II) \\
\hline & Noril 6 & I. mbmin & 418 & $1)(i$ & I'W'K & Alit: &.. & 1001 \\
\hline & Nural $?$ & 1. "1hmin & $40 k$ & $1)(i$ & PW' & Alit: &.. & .. \\
\hline 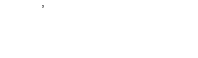 & Nind $K$ & 1.ubunin & 4018 & $1 x$ & IWK & Ali: &.$\cdot$ &.$\cdot$ \\
\hline T'utul & 9 linlts & & 6,624 & & & & & \\
\hline \multirow[t]{2}{*}{ Ilumpary } & l'ak, s & l'ak: & 1950 & $11 \mathrm{~N}$ & PWR & NA & $\ldots$ &.. \\
\hline & P'ukis & Puk's & $45(1)$ & $11 \mathrm{~N}$ & PWR & NA &.. & .. \\
\hline Toitul & 2 Inlts & & 1,9010 & & & & & \\
\hline \multirow[t]{8}{*}{ Prolund } & $k \| 1, n w y) 1$ & kuluwy & 4501 & (n) & IWK & Al:1: & .. & 11) \\
\hline & kujawy 2 & kujawy & 1950 & l'( ) & IIIR & Al: &.. & 11) \\
\hline & Kujaw' 1 & kulawsy & 450 & l'( ) & l'W'R & Al:I: & .. & (1) \\
\hline & kumusy + & kiljawy & 1150 & $P()$ & I'WK & Al:I: & & (1) \\
\hline & Wartat 1 & Klemples & 1150 & $W()$ & PWK & Alil: & & 111 \\
\hline & Warta： & Klemples & 150 & $W()$ & PWR & Al:1: &.. & (1) \\
\hline & W'arlit I & klemples & 450 & $W()$ & INWK & Al:L: &.. & 111 \\
\hline & Wallat & klemping & 950 & $W^{\prime}()$ & PW'R & Al!: & . & (1) \\
\hline
\end{tabular}


Table H2. Roster of Forelgn Nuciear Generating Units In the Construction Pipeline as of December 31, 1989, In Col'ntries with Regulated Market and Centrally Planned Economles (Continued)

\begin{tabular}{|c|c|c|c|c|c|c|c|c|}
\hline C'(1)1111) & \|\|$\left\|N_{0} \cdot\right\|{ }^{\prime} "$ & 1. 110116111 & 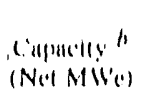 & l'tility' & $\begin{array}{l}\text { Rencing } \\
\text { lypere }\end{array}$ & $\begin{array}{l}\text { Rencleur } \\
\text { Sinpslien" }\end{array}$ & $\begin{array}{l}\text { l'ereont } \\
\text { Comprlete }\end{array}$ & 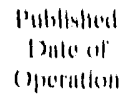 \\
\hline \multirow{4}{*}{$\begin{array}{l}\text { P'olumed } \\
\text { (continned) }\end{array}$} & Zarmonstere I & zintmonsere & 4.14 & $P()$ & PWR & Al:I: & 41 & 111 \\
\hline & Conmonteric : & Zаrmowises & 4.14 & Po & l'Nk & Al:L: & 30 & (1) \\
\hline & Zarmowiter 1 & Rinrmonites & 4.14 & $l^{\prime}(1)$ & I'N'K & Al: &.. & 11 \\
\hline & Zarmensices 4 & Zarmonseres & 4.14 & $l^{\prime}(1)$ & pliti & NI:1: & .. & (1) \\
\hline Intul & 12 lntes & & $1,3,36$ & & & , & & \\
\hline \multirow[t]{6}{*}{ Hemaniu } & Ronmunin I & ()川 & 4.40 & $(: K$ & l'Wk & Al!: & .. & .. \\
\hline & Cormatrindal & cortinsocta & 025 & $C K$ & PIIWR & Al: : & on & $1: 11 !$ \\
\hline & Cormaveda & 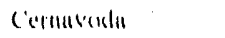 & 625 & $C K$ & IIIW'K & Al: & 40 & $(1 / 1) 4$ \\
\hline & commasodu 1 & Cormusondil & 1225 & $\mathrm{CK}$ & IIINk & Al: & 211 & $1 / 117$ \\
\hline & Cinnuscestas d & cermusula & 0.2 .5 & $C \cdot R$ & l'IIVK & Alic & 10 & $1) / 08$ \\
\hline & commondas & Cormavoula & 025 & C'K & PINK & 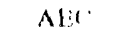 & 5 & $0 / 100$ \\
\hline Trutul & o l'nits & & 3,565 & & & & & \\
\hline \multirow{40}{*}{ 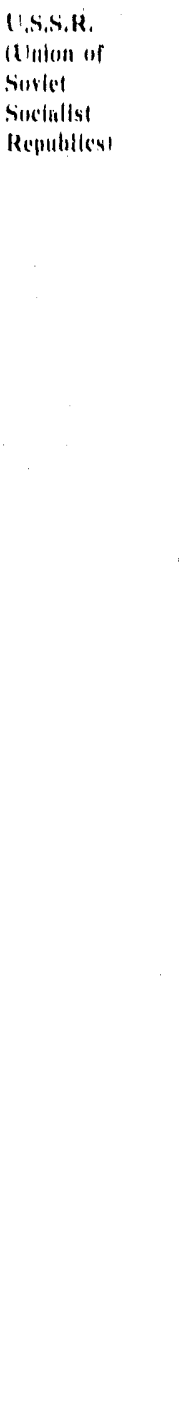 } & Hulukmose 4 & Halukosa & 9501 & UIR & piv'k & Al:E: & .. & f(x) \\
\hline & Malukirious & Malakivo & 9951 & UR & iWK & Al:L: & .. & 1405 \\
\hline & Maliakuva b & Mulukusu & $195(1$ & UR & l'WK & Al:i: & .. & .. \\
\hline & Muslikir I & Bushikir ASSR & 1150 & UR & I'WR & Al:!: & .. & $\mid(t)(\mid)$ \\
\hline & Bushkin : & Bushikir ASSSR & 1950 & IIR & I'WK & Al:t? & .. & 1w10 \\
\hline & Hashiki! I & Muslikir ASSR & 1950 & UR & l'WR & Alli: &. & .. \\
\hline & Haslikil a & Buslikir ASSR & 1950 & UK & l'wk & Al: : & .. & .. \\
\hline & Hekugursk + & Helovaraks & 750 & lik & liHR & Al:L: & .. & |40! \\
\hline & HN. Itoxi & Meloysursk & $1,5(x)$ & IIR & FHK & Al: : & .. & .. \\
\hline & Ignalium ! & Ismalima, l.ithmunin & 1,180 & U.R & I.OK & Al:t: & .. & .. \\
\hline & |gmulma! & Igmulima, l. ithumana & 1.380 & UR & LCHK & Al:L: & .. & (1) \\
\hline & kallinu I & Kulinin & 1750 & IIR & IPWR & Al:L: & .. & I)(1) \\
\hline & Kalinim \& & kialinin & 0501 & lik & I'WR & Al:E: & .. & |(x)| \\
\hline & Khasken 1 & Kharkos & 450 & UR & PWR & AlE: & .. & (1) \\
\hline & Kharkow : & Klourkos & 995 & UK & l'W'R & Al:L: & .. & (1) \\
\hline & Khmolnishi 2 & $\begin{array}{l}\text { Khmelnitski, } \\
\text { L/kraine }\end{array}$ & 990 & UR & PWR & Al:L: & .. & 1000 \\
\hline & Khmelnilstis 1 & $\begin{array}{l}\text { Khomelnilski, } \\
\text { l/kratIIC }\end{array}$ & 950 & IIR & PWK & Al:t: & .. & 10001 \\
\hline & 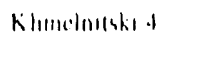 & $\begin{array}{l}\text { Khmelnitski, } \\
\text { likiante }\end{array}$ & 950 & UR & INWR & Al:L: & .. & $\mid(40) !$ \\
\hline & kinfloulun l & Kinll11)114) & 1,450 & UIR & I. IK & Al:L: & .. & |yc|, \\
\hline & Kintrema? & Kintrinina & 1,450 & IIR & LCik & Al:L: & .. & iwe \\
\hline & kinstronenis ! & Kuntruma & $1,4.50$ & IIR & l.cik & Al: : & .. & $1 / 00$ \\
\hline & Kinfrimm ot & Kustrullia & 1.4 .50 & UR & I. IR & AI:I: &.. & $1 / 01$ \\
\hline & kilists 5 & Kursh & 925 & IIR & PWR & AI:I: &.. & .. \\
\hline & Nishumehinmsh 1 & Ni/hinckemoush & 1150 & l. $1 k$ & PWR & Al:L: & .. & $1 / 80$ \\
\hline & Nishumekilmosh : & Nothinckumest & $(150)$ & IIR & PWR & Al $\vdots:$ & .. & $1 / 00$ \\
\hline & Norintekimmk! & Nizhinetionsh & 15010 & lIR & PW'R & Al: & .. & $\mid, 101$ \\
\hline & Nulumekismot + & Ni/hinekanmsk & $95(1)$ & lik & P'W'R & Al:1: & .. & $1 / 112$ \\
\hline & 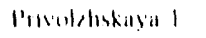 & Sarratus & 1150 & lik & PW'K & AI:I: &.. & .. \\
\hline & Pruciletistaya ! & Satalas & 950 & IIR & PWR & Al:I: & .. &.. \\
\hline & Provulathetayal & Suratus & 11501 & lik & PIWR & Al:I: & .. & .. \\
\hline & Porvoleholingat of & Sarulas & 1991 & IIR & PW'R & AI:I: & .. & .. \\
\hline & Kunlus: 1 & $\begin{array}{l}\text { Ruslus- } \\
\text { (n)-1he-1)(n) }\end{array}$ & 1950 & UR & PWR & Al:L: & .. & .. \\
\hline & Runlun : & $\begin{array}{l}\text { Romlwe. } \\
\text { (n)-l|k-1)on }\end{array}$ & 950 & IIR & PWK & Al:L: & .. &.. \\
\hline & Kustus 1 & $\begin{array}{l}\text { Ruslow. } \\
\text { (s)lllic-1)(1)1 }\end{array}$ & 1750 & IIR & PWR & Al:I: & .. & .. \\
\hline & Runlav a & $\begin{array}{l}\text { Rostwe. } \\
\text { (s) the-1)(11) }\end{array}$ & 1501 & IIK & P'K & Al:L & $\ldots$ & . \\
\hline & Kuslus 5 & $\begin{array}{l}\text { Kemlis. } \\
\text { (111-1h(c-1)(1) }\end{array}$ & 11501 & IIR & PWR & NIE: &.. & .. \\
\hline & Rumlex o & 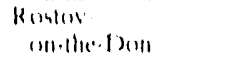 & 9501 & IIR & liNk & AI:1: &.. & .. \\
\hline & Rum & W'est lhralle & 1950 & IIK & I'WK & All: & .. & 1900 \\
\hline & RuYnus & West l/hraine & $1 / 50$ & IIR & PWR & Al:I: & & .. \\
\hline & Rusm:" & W'est Ikrame & 115.1 & lik & PWR & Al: & & .. \\
\hline
\end{tabular}


Table H2. Roster of Forelgn Nuclear Generating Units in the Construction Pipeline as of December 31, 1989, in Countries with Regulated Markei and Centrally Plannesi Economies (Continued)

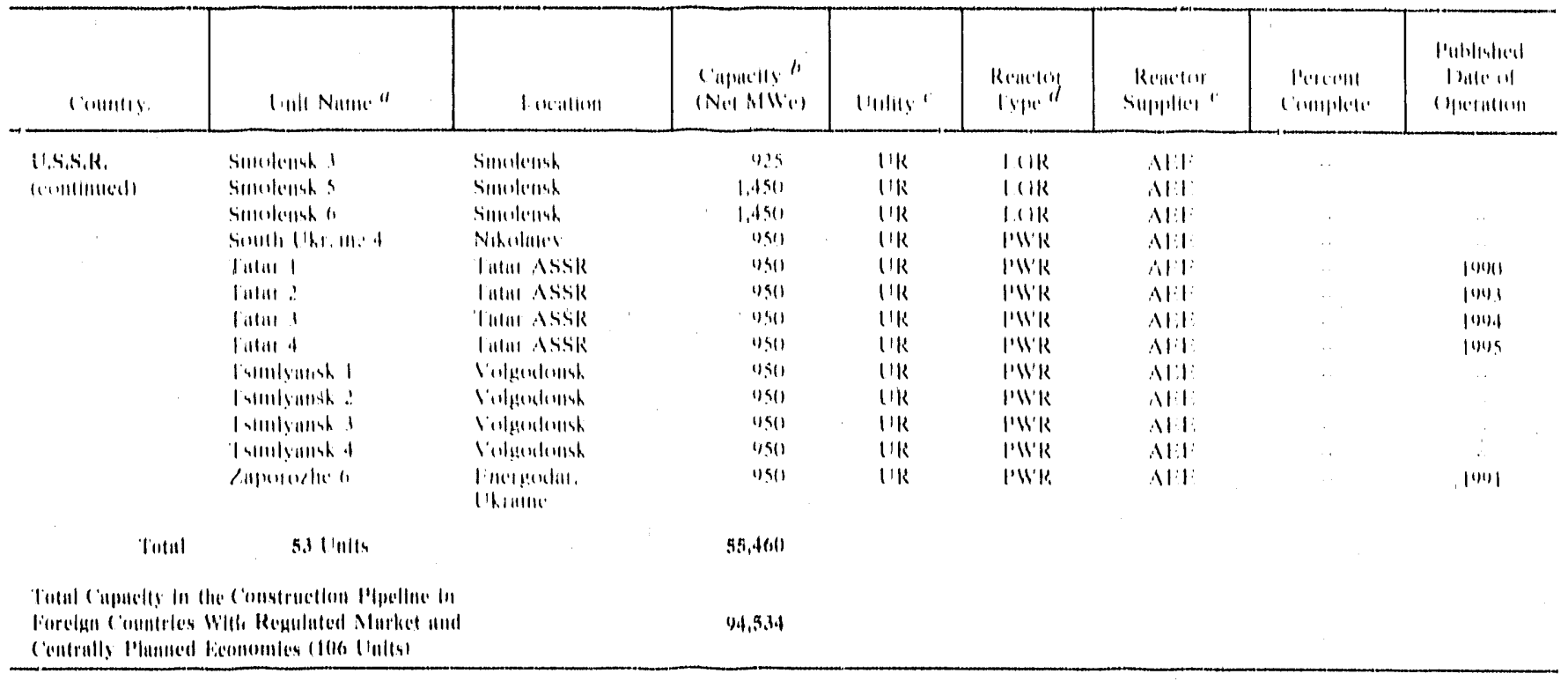

\footnotetext{
"IEA क

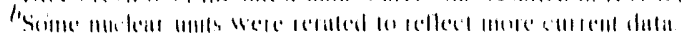

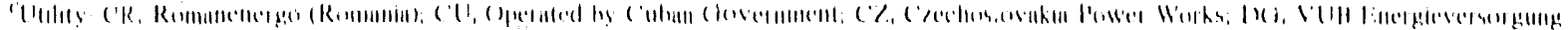

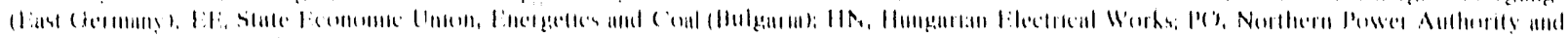

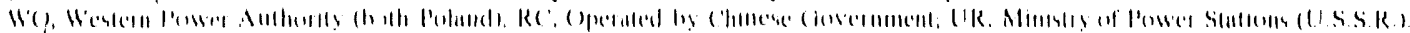

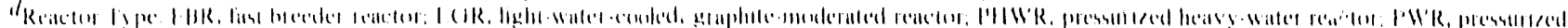
willer 1 cistur

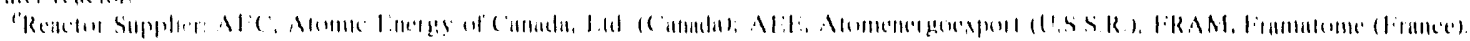

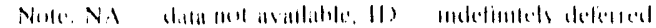

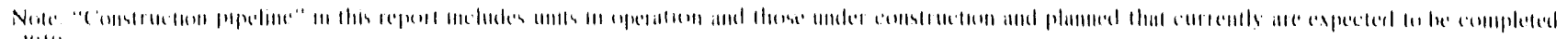
(1) $2(1111$

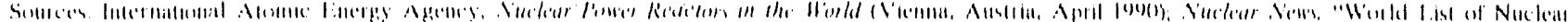

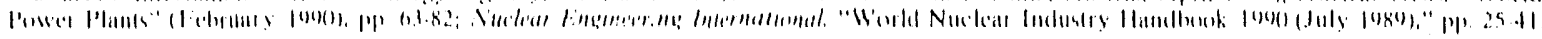




\title{
Appendix I
}

\author{
Annual Capacity \\ and Generation \\ Projestions for \\ U.S. Nuclear \\ Power Supply \\ Scenarios
}




\section{Appendix I}

\section{Annual Capacity and Generation Projections for U.S. Nuclear Power Supply Scenarios}

The projections contained in this appendix were developed in accordance with the assumptions detailed in Chapter 2 of this report. Table 11 provides the annual detail supporting the capacity projections for each nuclear power supply scenario shown in Table 5 and Table 8 . Table 12 presents annual net generation projections for each nuclear power supply scenario. "*
The post-2010 capacity projections are based on a linear interpolation of nuclear capacity requirements estimated at 5-year intervals beginning in 2011 for the Lower Reference and Upper Reference cases. Therefore, these projections should be regarded as annual averages. 
Table 11. Annual Projections of U.S. Operable Nuclear Capacity at the End of the Year (Net Gigawatts-Electric)

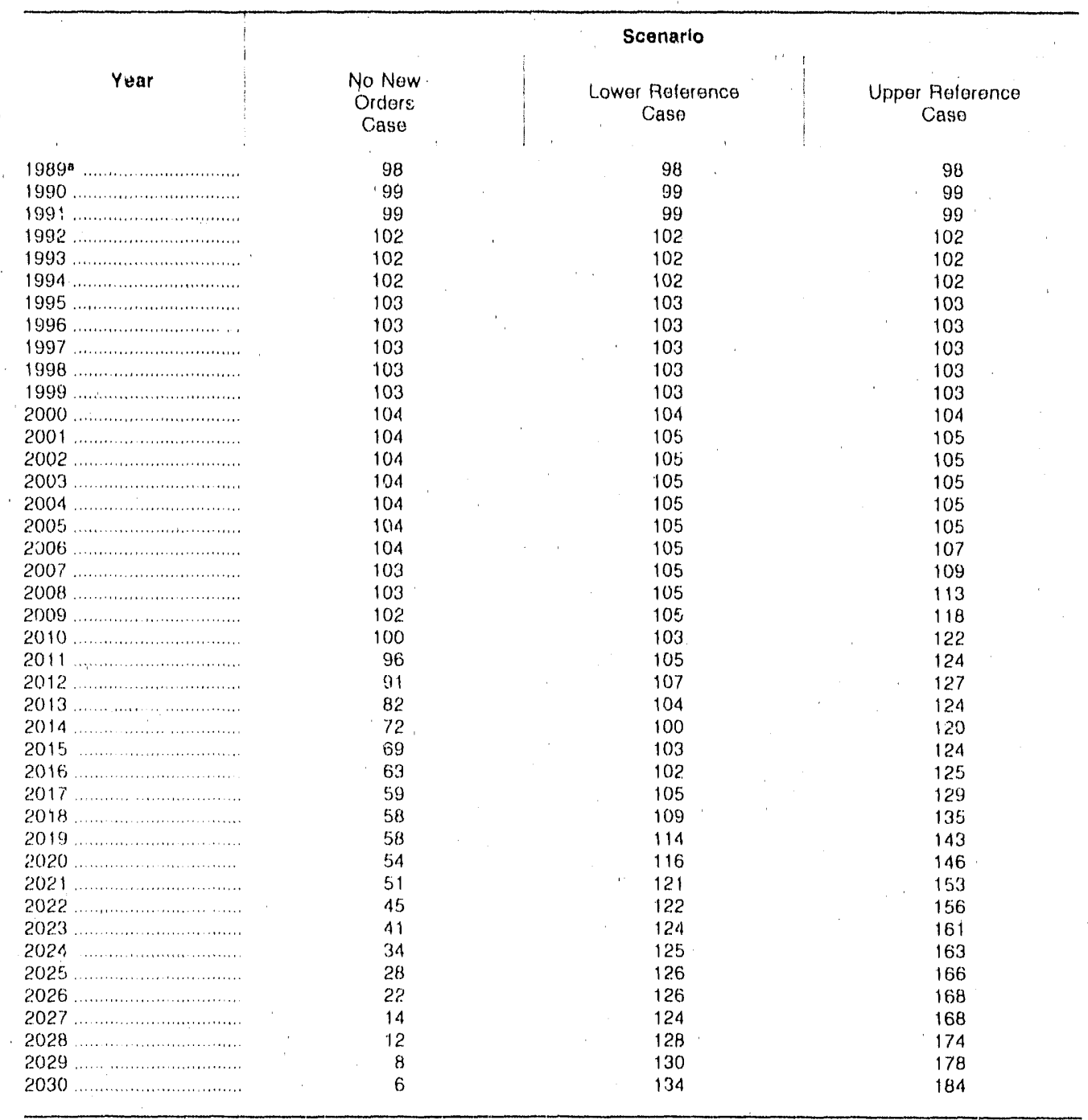

a Actual.

Sources: 1989-2010--Eriergy Information Administration, Annual Energy Outlook,DOE/ElA-0383(90). Post-2010-WINES Model. 
Tal le 12. Annual Projections of U.S. Nuclear Generation (Net Terawatthours)

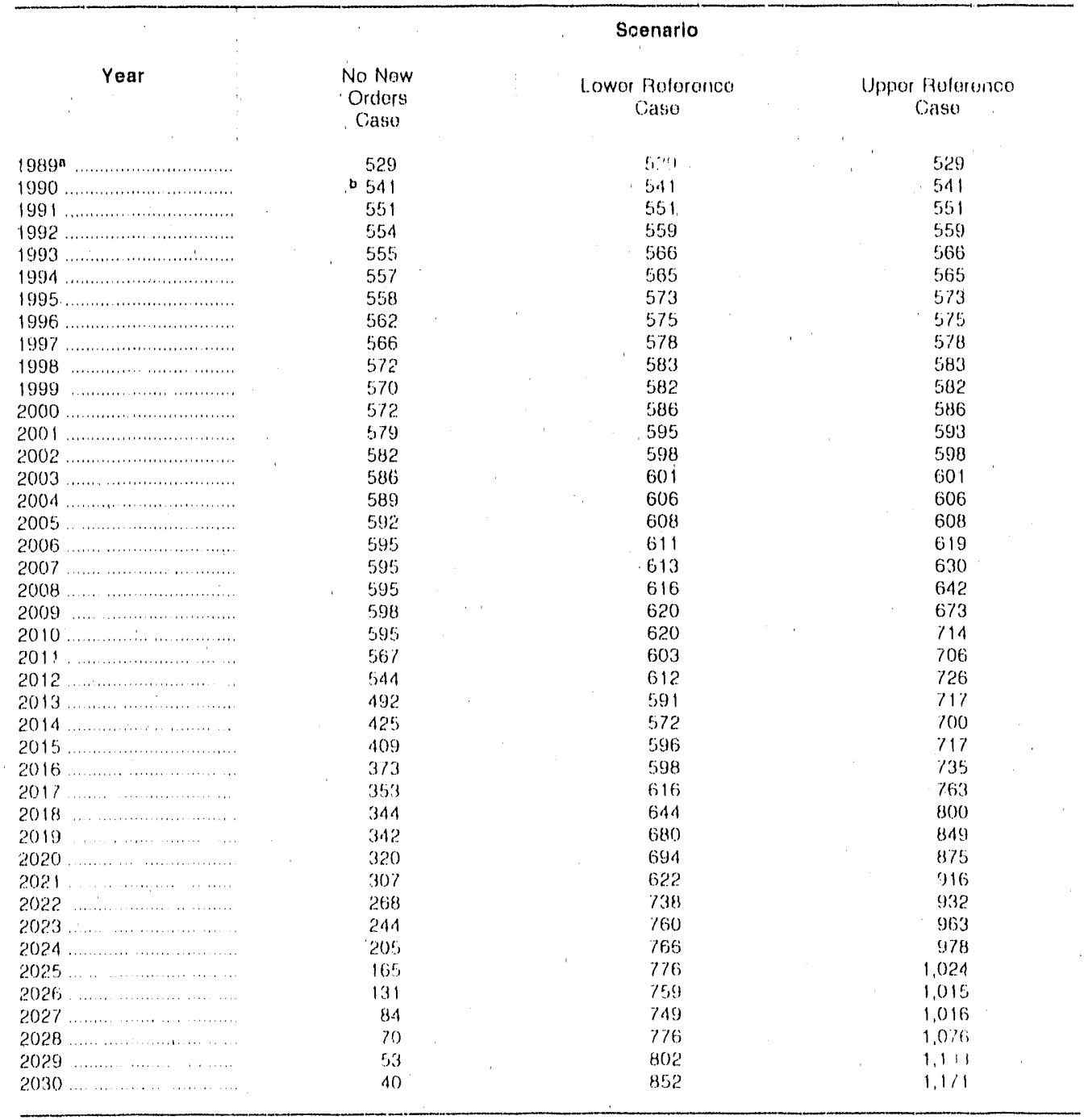

aclual.

b Value from the AEO was replatced by the value from the Interrationat Nuclear Modol.

Sounces: Historical Generation Data-Energy Information Admirnstration, Monthly Energy Revew. December 1988, DOE/E:IA-OO35 (88/12) (March 1989). Projected Generation-No Now Orders Caso-. 1960).2010, Annual Energy Outiook (1900). [OOE/E:A-0383(90); 2011.2030. Intornational Nuclear Model (INM) (19899). Lowor arid Upper Refer. ence (Cases - $1990 \cdot 2030$, INM. 
Appendix $\mathbf{J}$

Status of U.S. Nuclear Plant Construction 


\section{Status of U.S. Nuclear Plant Construction}

\section{Introduction}

This Appendix presents eonstruction cost and milestone data for nuclear units in the construction pipeline," canceled, or in commercial operation as of De. cember 31, 1989. The data in this appendix were collected from nuclear utilities on Form MilA-254, "Semiannual Report on Status of Reactor Construction." "? In some instances, the data presented here may vary from that presented in the body of the report since the soure there for the comparable data is llac U.S. Nuclear Regulatory Commission.

\section{Discussion}

The construction costs reported in ' lables Jl and .12 comprise the total cost of the nuclear plant and can be regarded as the fixed investment or capital costs of the plant. The reguested cost estimates are disaggregaled into direct costs, indirect costs, contingency costs, common facilily costs, and Allowance for linds Used Dur. ing Construction (AFUDC). Estimales of direct costs are further disaggregated into the following caltegories:

- Land and land rights

- Structures and improvements

- Reactor plant equipment

- rurbogenerator units

- Accessory clectric equipment

- Miscellaneous power plant equipment.

For each nuclear unit, the estimated cost data provide an indication of the total expected construction costs and a recond of revised estimates. Reported ensts are in mixed corrent dollars: that is, the costs are in courtent collars of a mumber of different years.

During log8, 5 moits entered commercial operation, 8 units were under construction, and 7 were doferted.?

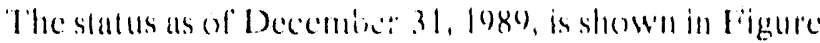
J1. Of the 8 units under construction in 1988, 2 entered enmmercial operation during 1989, and 5 mints were still under comstruction. One unit, Shomeham, was deferred in 1989, and one unit, Grand (iulf 2, was canl. celed during lo89. There are corrently 7 deferred innils in the construction pipeline.

During 1989, (wo nuclear units entered commercial operation: Vogtle 2 (cieorgia) and South lexas 2 (Texas). These units entered commercial operation in May and June 1989, respectively. These units have a net summer capability of 2.3 GWe and a total construction cost of $\$ 4.2$ hillion.

For the live units remaining under construction as of December 31, 1989, the estimated net stmmmer capability is 5.7 GWe and the ontal construction cost is estimated al $\$ 21.7$ billion.

In Tuble Jl, the five units actively under construction as of December 31, 1989, are gremped by year of commercial operation as reported by the utilities in the 1989 survey. Commercial operation dates are estimates by the ulilities and are subject to change. These data show that three of the five units under construction were expected to be in commercial operation by the end of $100(0)$ representing a total nel summer capability of 3.4 (iWe and estimaled colal construction expenditures of $\$ 13.5$ billion (in mixed current dollars). Two units are expected 10 conter commercial operation in 1991 representing a total net summer capability of 2.3

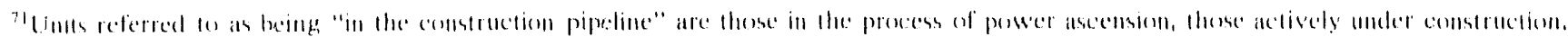

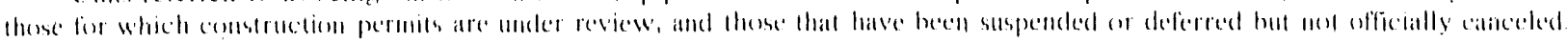

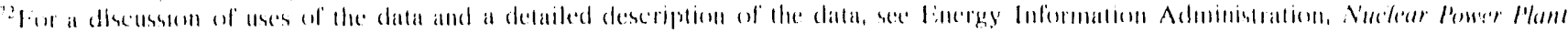

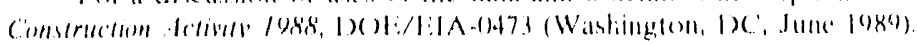

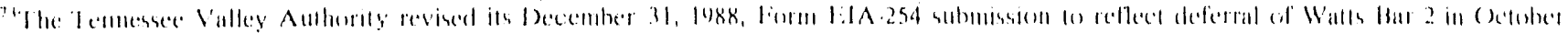

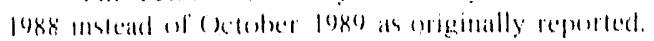

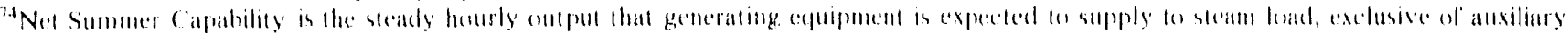

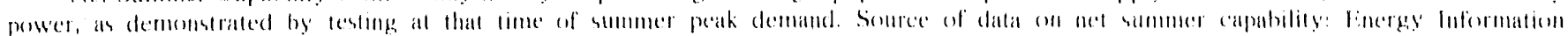

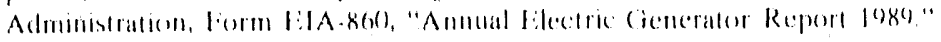


GWe and estimaned total constrmetion expenditures of $\$ 8.3$ billion.

Table d2 showes reacedespecifie data as of Decomber 31. 1989. Data (n) nllclear power plant comstruction

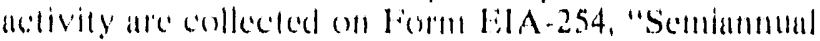
Repurt on Status of Reactor Comstruction." Results of this survey were previously reported in a report titled.

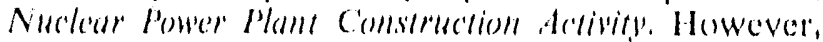
because of show construction activily and a diminishing survey frame, this report was discombinued after publiculion of the log8 velsion. 'The results of the survey will be included in fulure issuses of Commenereval Nuclear

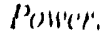

\section{Table J1. Total Net Summer Capability and Estimated Total Cost of U.S. Nuclear Units Actively Under Construction, by Year Expected by Utillity to Enter into Commercial Operation}

\begin{tabular}{|c|c|c|c|c|}
\hline & $\begin{array}{c}\text { Expected Year ut } \\
\text { Entry Into } \\
\text { Commercial Oporatlon }\end{array}$ & $\begin{array}{c}\text { Numbor of } \\
\text { Units: }\end{array}$ & $\begin{array}{c}\text { Tolal Nol } \\
\text { Summor } \\
\text { Capability } \\
\text { (GWo) }\end{array}$ & $\begin{array}{c}\text { Ealinalod } \\
\text { Tolal Cost } \\
\text { (billlon dollars) }\end{array}$ \\
\hline 1940 & $\ldots \ldots \ldots \ldots$ & a 3 & 3.4 & 5135 \\
\hline 19491 & $\ldots \ldots, \ldots$ & $i^{\prime}$ & 23 & $0 . ?$ \\
\hline lotill & … $\quad$ … & 5 & 6.7 & $? 1.7$ \\
\hline
\end{tabular}

- All throe of these, units actually onterud commorcial oporaltion in the lirst hall of 1990.

"Estunated total costs for one unit include Af LIDC: (Allowance for Funds Usod During Consilruction) for the majority owner only. Noto. Costs are in mexod-curront dollars

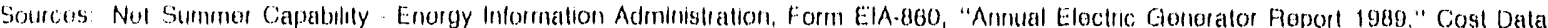

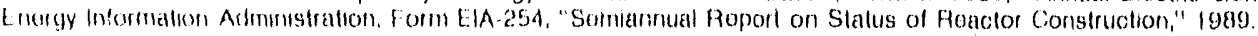

\section{Table J2. Reactor Specific Data for Nuclear Units as of December 31, 1989}

\begin{tabular}{|c|c|c|c|c|}
\hline \multirow[b]{2}{*}{ Unlt Name } & \multicolumn{3}{|c|}{ Units That Entered Commerclal Operation In 1909} & \multirow{2}{*}{$\begin{array}{c}\text { Canceled Units In } 1989 \\
\text { Dato of Cancellation }\end{array}$} \\
\hline & $\begin{array}{l}\text { Commorcial } \\
\text { Oporatron Dalo }\end{array}$ & $\begin{array}{c}\text { Not Summel } \\
\text { Carpatility (MWo) }\end{array}$ & $\begin{array}{c}\text { Final Cost } \\
\text { (llousand dollars) }\end{array}$ & \\
\hline Vorglle? & May 1989 & 1,0866 & $2,582,000$ & . \\
\hline Soulh loxas? & Jund 1989 & 1,250 & $1,648,675$ & . \\
\hline Cinand Ciull :' & & . & & Septomber 1989 \\
\hline
\end{tabular}

\begin{tabular}{|c|c|c|c|c|c|}
\hline \multirow[b]{2}{*}{ Unit Name } & \multicolumn{5}{|c|}{ Unlts Remalning Under Construction } \\
\hline & $\begin{array}{c}\text { Esturnalod Commorcial } \\
\text { Operation Date }\end{array}$ & $\begin{array}{l}\text { Not Summor } \\
\text { Carrability (MWo) }\end{array}$ & $\begin{array}{c}\text { Estlmatod } \\
\text { Final Cost } \\
\text { (thousand dollars) }\end{array}$ & $\begin{array}{c}\text { Disbursed } \\
\text { I AFUDC; } \\
\text { (thousend dollars) }\end{array}$ & $\begin{array}{c}\text { Disbursod } \\
\text { Commilments } \\
\text { (thousand dollars) }\end{array}$ \\
\hline 1.m+menc:k? & January 1990 & 1,055 & $2,809,600$ & $2,769,400$ & $2,809,600$ \\
\hline Comanche 1 & March 1990 & 1,150 & $6,192,006$ & $6,411,699$ & $6,411,699$ \\
\hline$\ldots \ldots \ldots$ & March 1990 & 1.150 & $5,490,549$ & $5,400,549$ & $5,490,549$ \\
\hline Comanche ¿ & June 1991 & 1,150 & $3,599,75 a$ & $2,681,056$ & $2,681,056$ \\
\hline Watls Bar I & (xctolest 1991 & 1,170 & $4,616,606$ & $4.296,113$ & $4,324,913$ \\
\hline
\end{tabular}

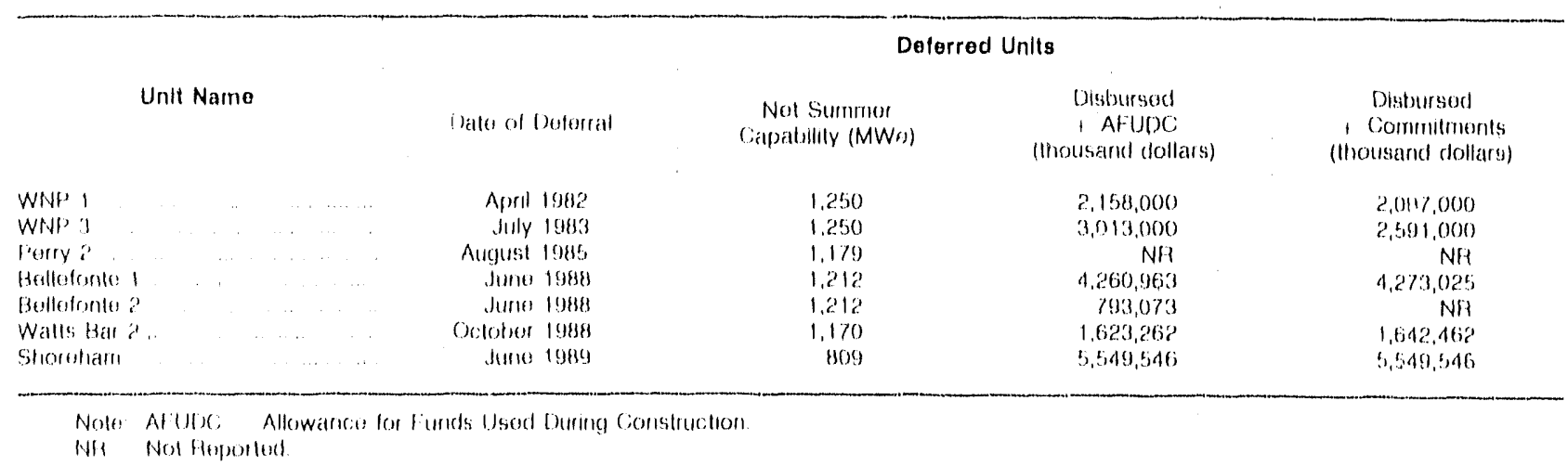


Figure J1. Status of Nuclear Plant Construction as of December 31, 1988 and December 31, 1989

As of Deoember 31,1888
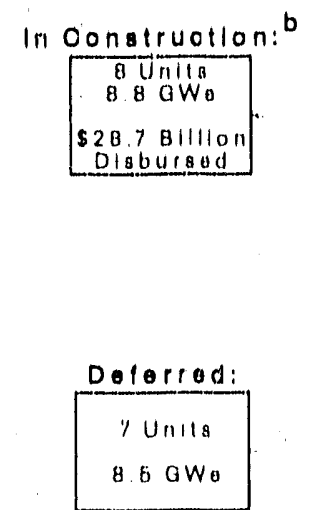

(1)
As of Dooember 31,1080

In commerolaloperatlon:

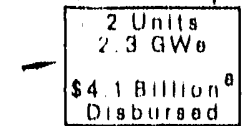

In Oonatruation:
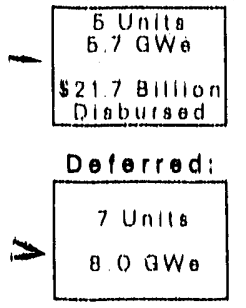

Canoeled:

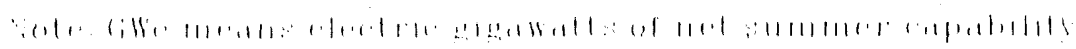

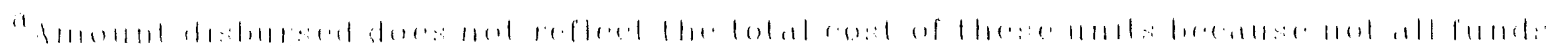

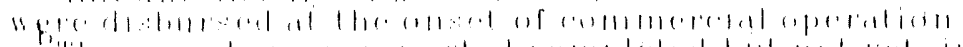

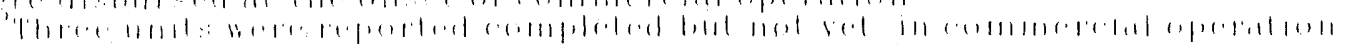

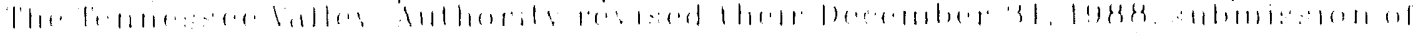

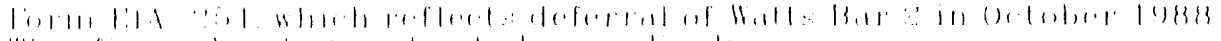

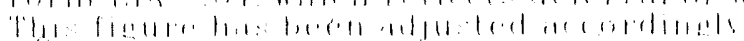

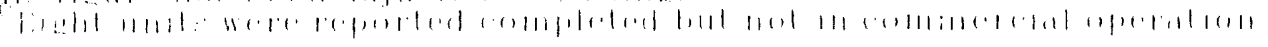

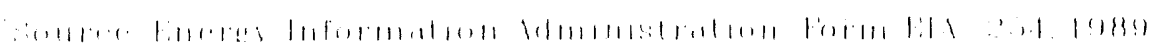




\section{Glossary}

Avallability lanctor: A pereentage representing the: mumber of hours a reactor is available to generate pervere (regardless of the amontme of power) in a given peried, compared to ble number of heurs in the period.

Backfit: A cerm applied to the installation of a new system aller an original system is in place, or the modification of the original system after it has been commpleted. This refer's 10 changes mandated by the U.S. Nuclear Regulatory Commission or by saffely agencies in forcign countrices.

Bulancerof plant: The components of a nuclear power plant outside the Nuclear Steam Supply System (NSSS).

Baseload: The minimum anomin of electric power de-

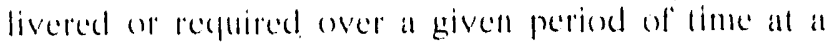
steridly stalle.

Baseload Capacity: The generating equipment normally oprerated to serve loads on a round-the-c-lock basis.

Bascload Plant: A plann, usually housing highefficiency stean-clectric ar nuclear generating units, which is normally operated to take all or part of the minimum load of a system, runs continuously, and produces electricity at an essentially constant rate. These units are operaled 10 maximize system mechanical and thermal efficiency and minimize system operating costs.

Boiling-Water Reactor (BWR): A light-water reactor in which water, used ats both conlant and moderator, is allowed to boil in the core. The resulting steam can be used directly wo drive as lurbine.

Bormed Water: Walce conlaining a high concentration of borcon, a neutron-absorthing element. The introcluctom of boraled water into a reacter slows the reaction ralle by absorbing free neutroms.

Brecder Reactor: $A$ rencter that produces lissionable fuel an well ats consuming it, especially one that creates more fued than it consumes. The new lissionable marerial, in created by a process known as breedinge in which nentrons from fission are captured in fertile mat" krials.

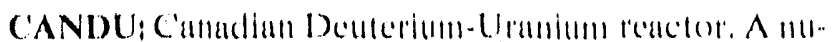

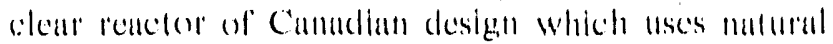
uranium as a fied and heavy waler as a moderator and crovlant.

Capacity: The full-foud capubility of a generating wnit 10 produce electrical energy for a given time period and under specified conditions. The units of conpucity are typically kilowalls or megawalts. In this report. U.S. "captacily" refers to net summer capability (sece below).

Capacity Factor: The ration of the electricity produced by a generating wnit, for the period of time considered. to the encergy that conld have been produced al conttinuous full-power operation during the sume period.

CPli: Centrally Planned Economies: (China, Cuba, North Korea and the USSR).

Commerclal Operation: The phase of reacter operation that begins when ponver ascension ends and the operating utility formally declares the nuclear power plant to be available for the regular preduction of electricity. This dectaration is ustually related to the satisfactory completion of qualification lests on erilical components of the unit.

Confinement: A reinforeced building surrounding the reactor vessel and most or all of the primary radionactive circuits of a nuclear reactor, designed io withstand above-normal pressure and minimize radiation relense in the event of a leak or rupture in the system. less secure than a containment.

Construction Pipeline: The valrous stages involved in the acquisition of a nuclear reactor by a utility. The events that define these slages are: the ordering of a reactor, the licensing processe and the physicall contstruction of the nuclear generating unit. A reactor is said ob be "in the pipeline" when the reacter is ordered and "out of the pipeline" when it becomes operable. (See: (operable.)

Containment: A massive stect-and-concrete structure surrounding the reacher vessel and most or all primary

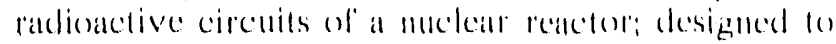
willsstand extreme pressure and prevent the release of madiation in the event of a leat or rupture inside the system. 


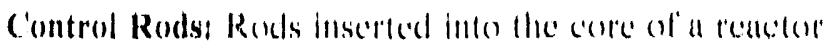

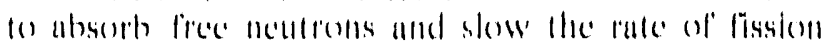
rencetionsis.

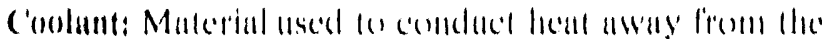

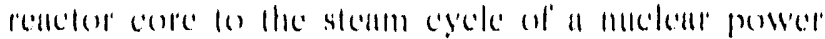

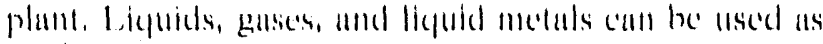
corclants.

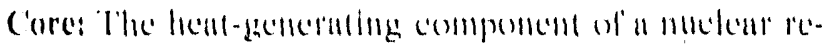

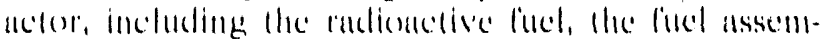

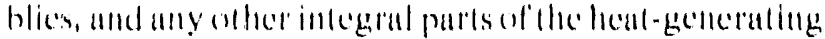

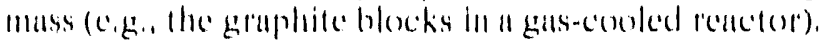

C'riticulity: The condition in which a mucleat renction

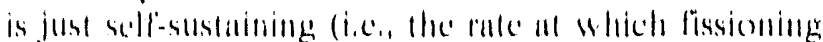

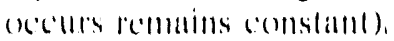

Cycle length: the lenghth ol time a reactor is operaled

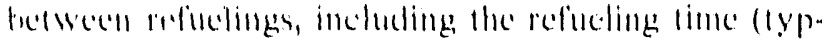
ically, 141018 monilhs).

Design Vilectrical Ratlug (Cupacity), Not: The Momimal

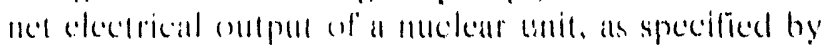

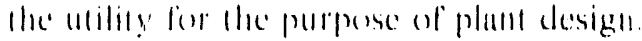

Silasticity of Demand: The ratio of the percentage chamge in demand for a produce to the pereentage change in allother variable, stech as price or income.

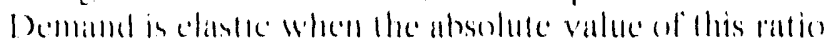
exicecels ! 0

fapulibrium cycle: An analytical lerm which refers lo

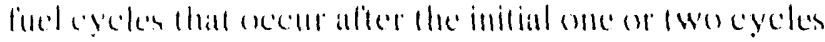

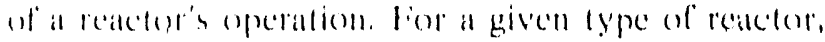
equilihrium cyeles have similar fucl characeristics.

linst Breceder Reactor (IIBR): A reactor in which llae lission chain rencelion is sustained primarily by list ned1troms rather than by thermal or intermediale neutrons.

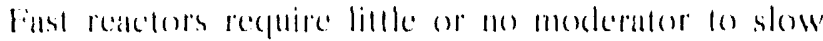
down the nentroms from the speeds at which they are cejected from lissioning nucled. This lype of reaclor pro. duces more lissile material than il comsumes.

Fertile Material: Malerial that is llot ilself lissionable by thermal neutrons hat can be comverted to lissile material by iradiation. The awo princepal fortile macerials are 11 randum-2.38 and therium-2.32.

Fisstle (Fissionable) Material: Matcrial that (ain he catused lo underge atomic fissionl when hombarded by neutroms. The most important rissionable materials are

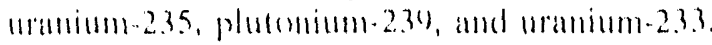

Fission: The process wherehy an atomice mocleus of appropriale lype, after captering a mentron, splies inter (genterally) two noleled of lighter clements, with the relense of substantial amounts of energy and lwo ar molle mentroms

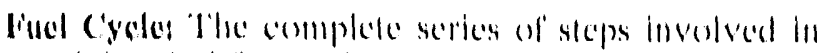

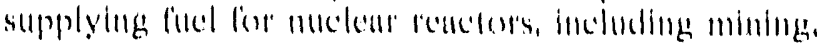

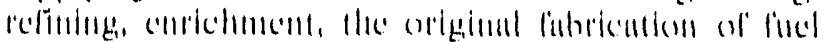

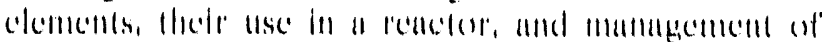

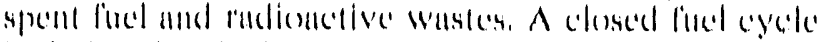

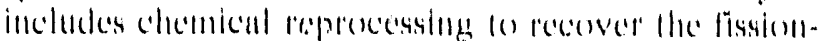

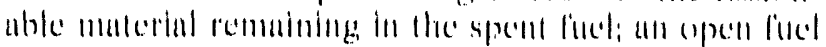
sycele does 1101.

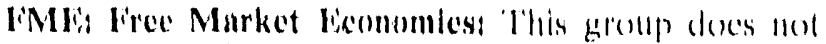

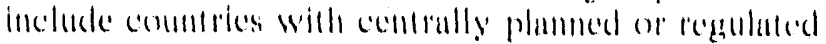
mankel economiss.

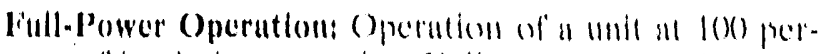

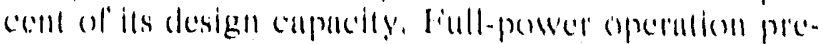
codes commerelal operation. (Sece ()perable.)

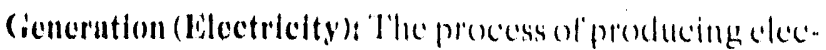

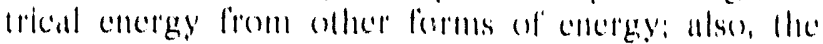
amount of electrical energy prodecerl, expressedel in wallhulus (Wh).

Cioneration (Cross): 'The lotal amound of electric energ! preduced by the generating units in a gencraling stution (1) stutions, monsured all the gencrator terminals.

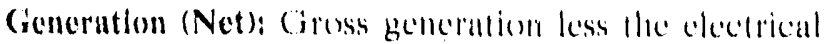
chergy constumed at the gentruting station for station IIsi',

Gigawatt-cloctric (CiWe): ()ne hillion walls. (See Walt.)

Graphite: A crystalline form al curbon used fo moderalce moclear reactions.

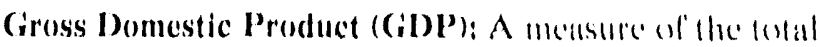

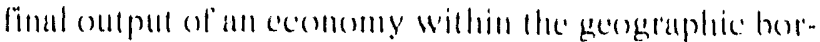
ders of the commtry by residents and nomresidents, regardless of the allocention on domestic and foreign claims.

Gross National Product (GNP): A measmere of the fimal oulput of goods and services by cilizens of a collutry, whether living al home or in foreign commlries. (iN) comprises (iD) and faceor insomes from abrond accruing to residents, less the income enrned in the domestic ceomomy acertuing to citizens of oflere countries.

Halving finctor (Time): The lime fiom the hase year reguired for a variahle on reach the midpoint between its base'yeat value and its asymplotic vallas.

Heavy Water: Water combaning a signilicanlly grealion proportion of lacavy hydrogen (denteriume atoms

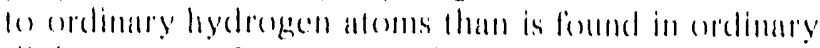
(light) waller. Heavy waller is llsed as a moderator in

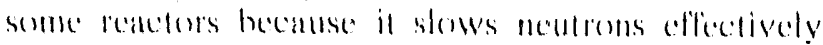

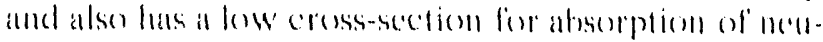
Irills. 


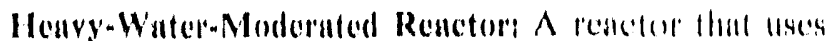

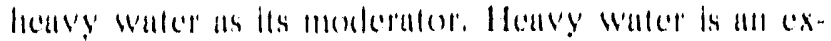

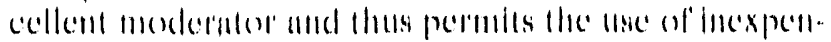

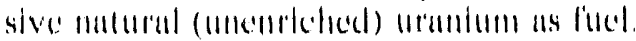

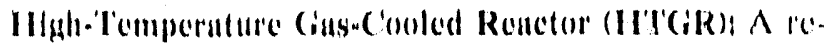

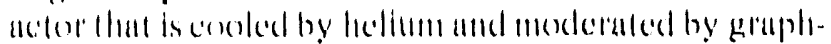

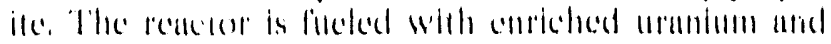

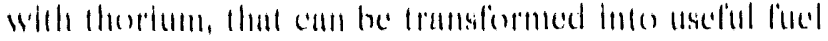
when it is irradiuled.

Inhorent Sufety: Suldety lhul is provided by the physicul

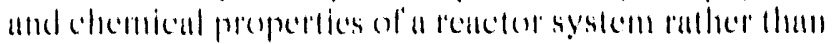

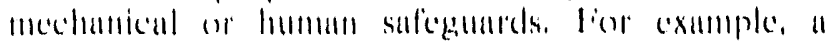

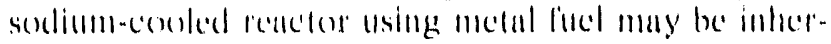

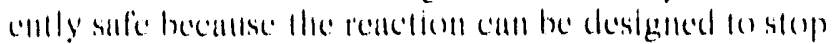

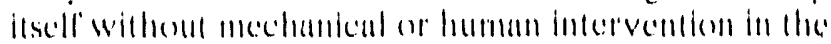

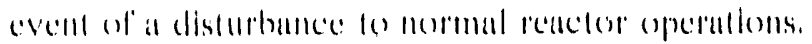

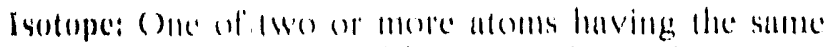

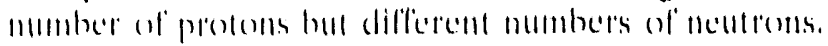

Kllowatt-electric (kHo): ()tle llousand walls. (Sce Will.)

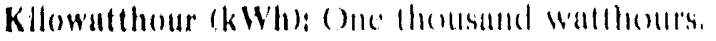

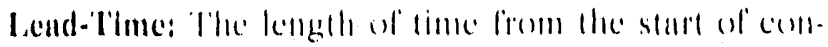

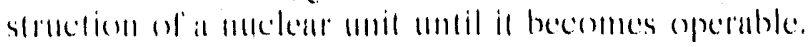

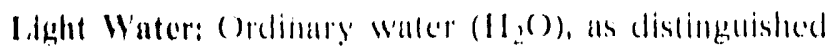
from heavy water or deuterium oxide (D) 20$)$.

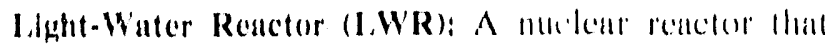

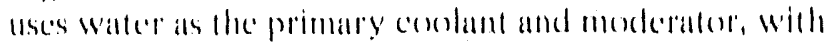

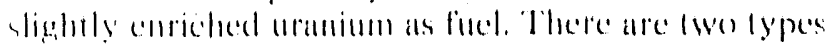

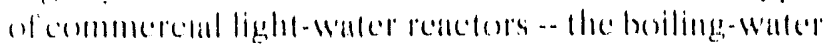

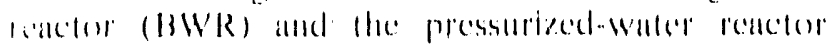
(l'WR).

lilquid Metul liust Breeder Renctor (1.MliBR): A

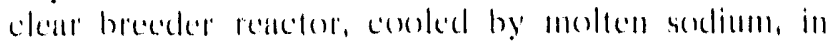
which lission is callsed hy fast newloms.

load following Regulation of the power oulput of electrice generators within a prescribed area in response to changes in system freculedey, ticline loading, or the

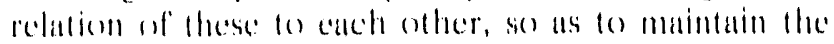

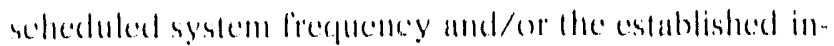
lerehange will onlere areas within predelermined limils.

Low-Power Testlng: "llie period of time belween

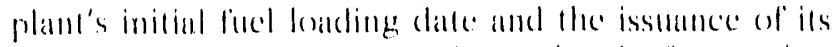
full powere license. The maximum level of (operation during thie periond is 5 peresent of the mont's designt ther'inal ralling.

Market (I.ogistic) Penetration Model: An exponemtial trend function in which the rate of ghoweth begins all a

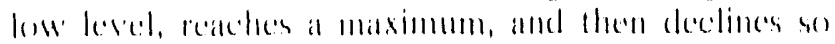

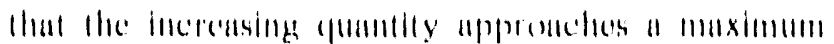
valuc (ass'min)lul(!),

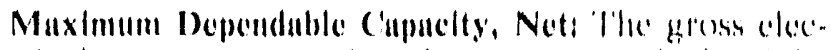

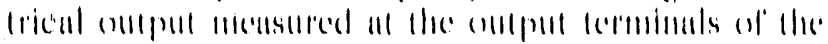

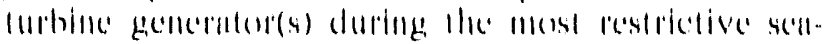

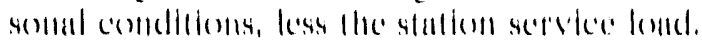

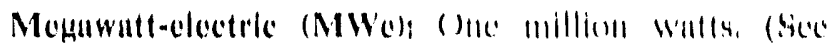
W'III.)

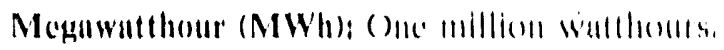

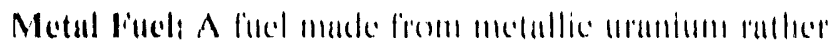

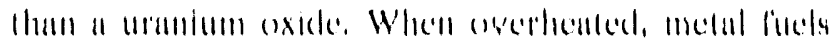

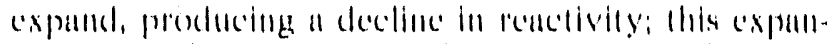

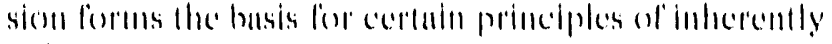
sufec rencturts.

Moderator: A mulceinl, such as ordinary walce, heavy

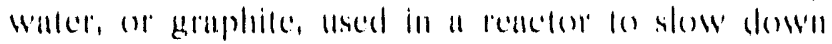

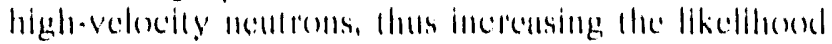
of further fissiton.

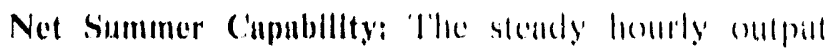
which generating :efuipment is expeceled lo stupply lo a system lond exclusive of andiliary powerl as clemont-

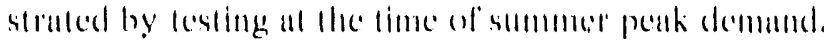

Nuclear Power Plant: $\Lambda$ single- or multi-nnil fincility in

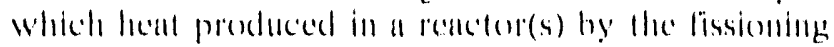

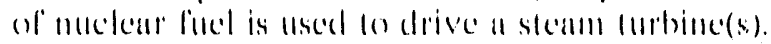

Nuclear Reactor: All apparalus in which Ihe ntcelear

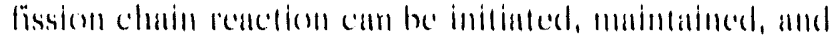

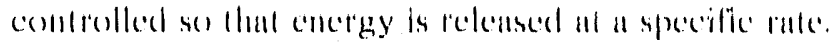
The rencene apporalles includes fissiomuble material

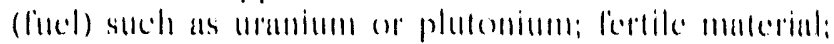

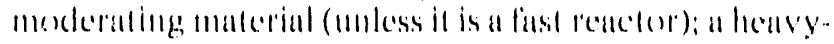

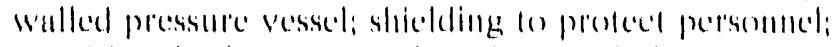

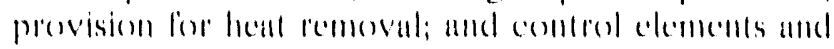
instrumentalion.

Nucleur Steam Supply System (NSSSS): The e(yuipmentur

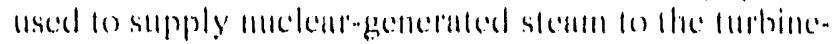
generalor, comsisting primarily al the rencelor vessed innd all inlermals; the primary cenolant system and all

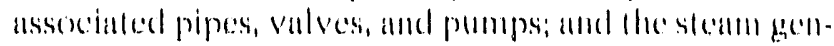

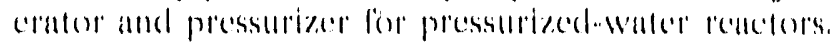

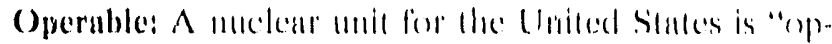
crable:" afied it compledes low powere lestimge and is issuced a full powere license by the Nucelent Regulalury

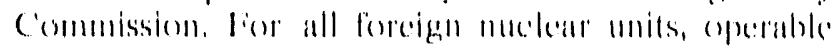

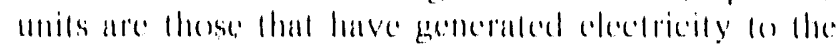
privil.

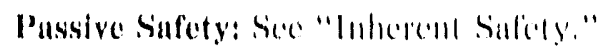

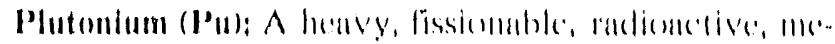

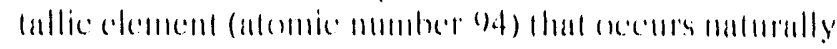




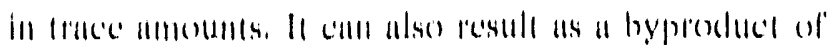

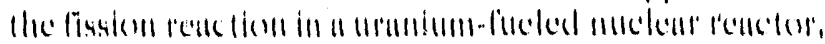

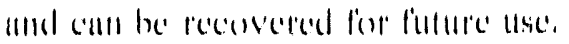

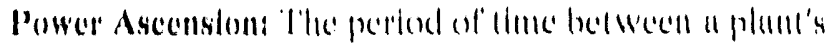

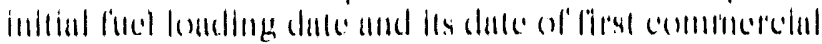

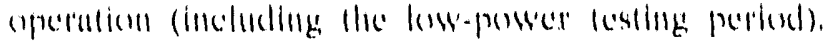

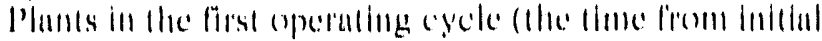

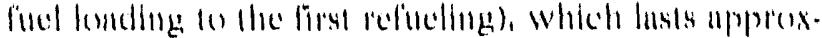

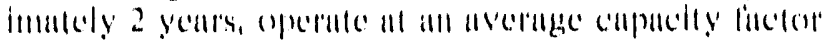
(1) ilbuill 4 (1) percecill.

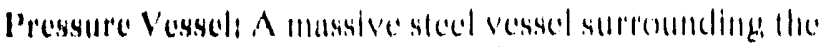

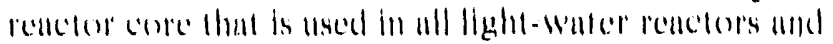

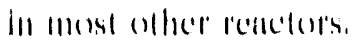

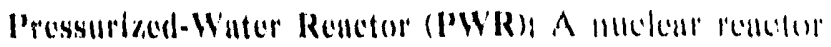

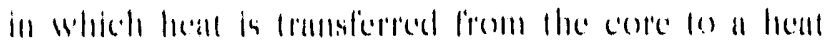

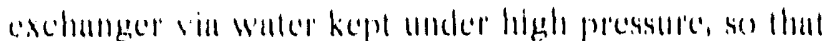

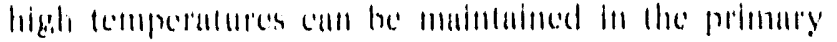

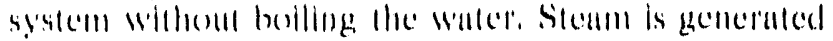
iil 1 secomelary circeuil

RML: Regululed Market feomomiles (formerly centrally plannod economies).

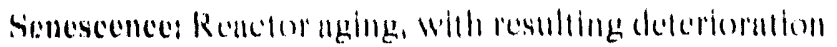

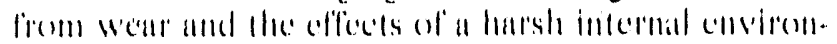
III'IIl.

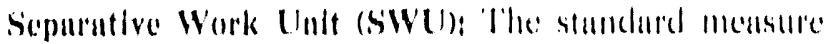

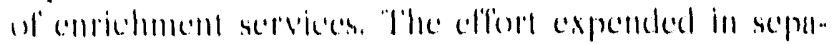

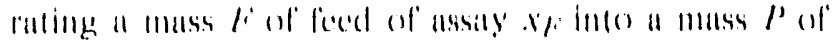

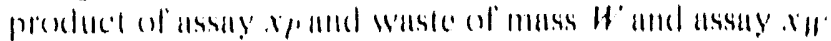

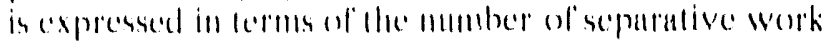

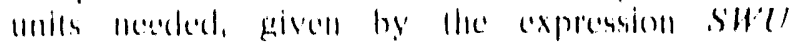

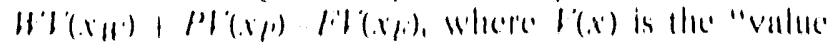
functionn," definced as fo(x) (1 $\left.2 . x) \ln \mid\left(\begin{array}{ll}1 & x\end{array}\right) / x\right]$.

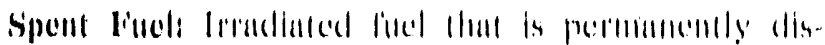

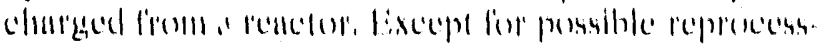

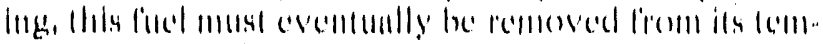

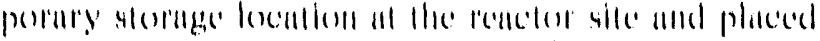

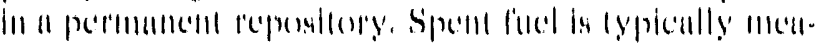

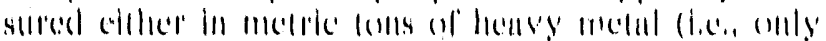

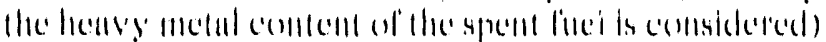

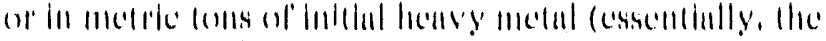

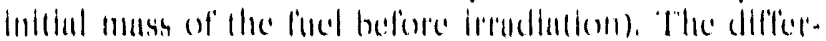

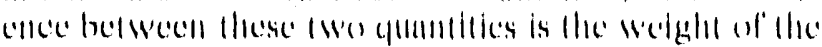
lïssion products.

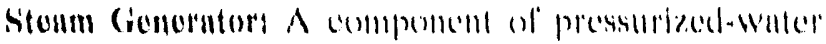

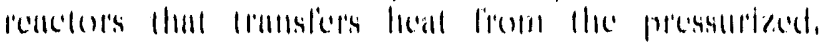

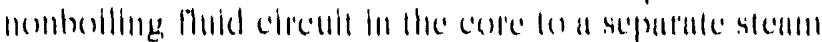

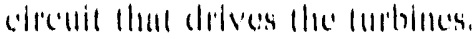

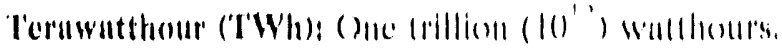

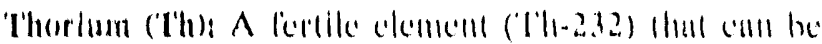

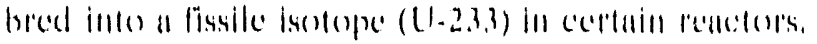

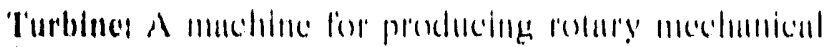

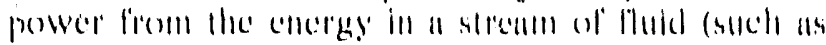

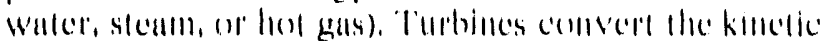

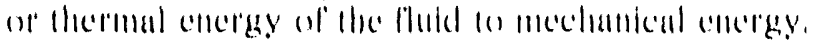

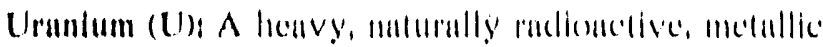

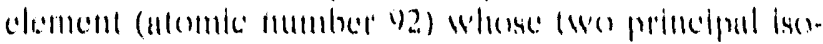

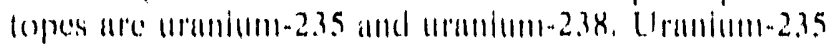

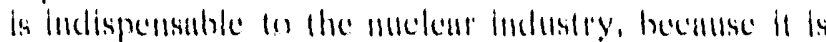
the only isolope cexisting in malure lo any appreseduhle

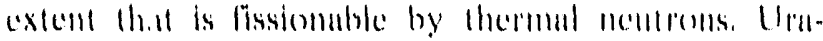

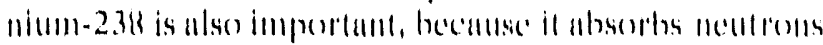

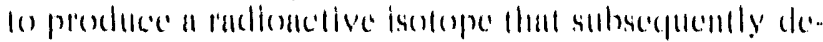

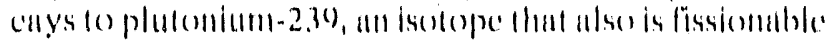
by hermal newtroms.

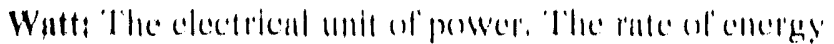

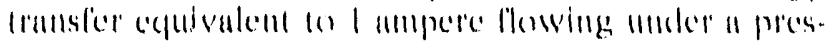

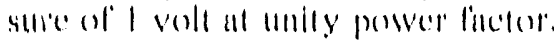




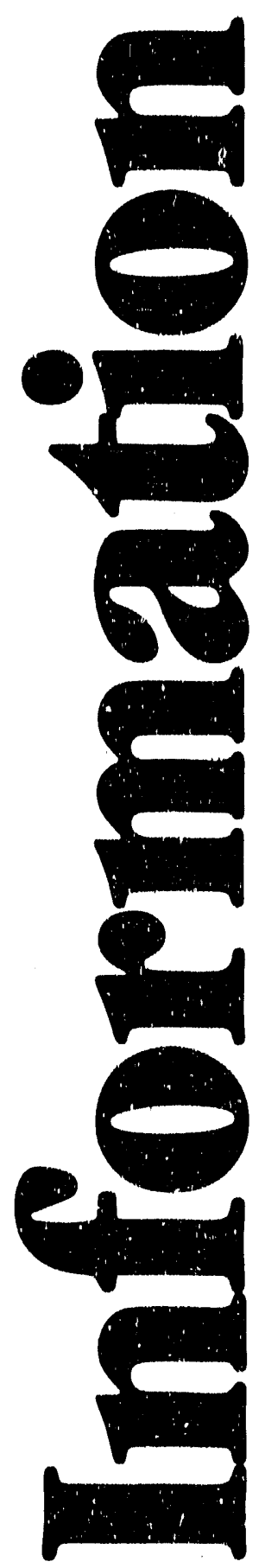

Information from the Federal Government on subjects ranging from agriculture to zoology is available at Depository Libraries across the nation.

You can visit these libraries and use the Depository collections without charge.

To find one in your area, contact your local library or write: Federal Depository Library Program, Office of the Public Printer, Washington, DC 20401. 

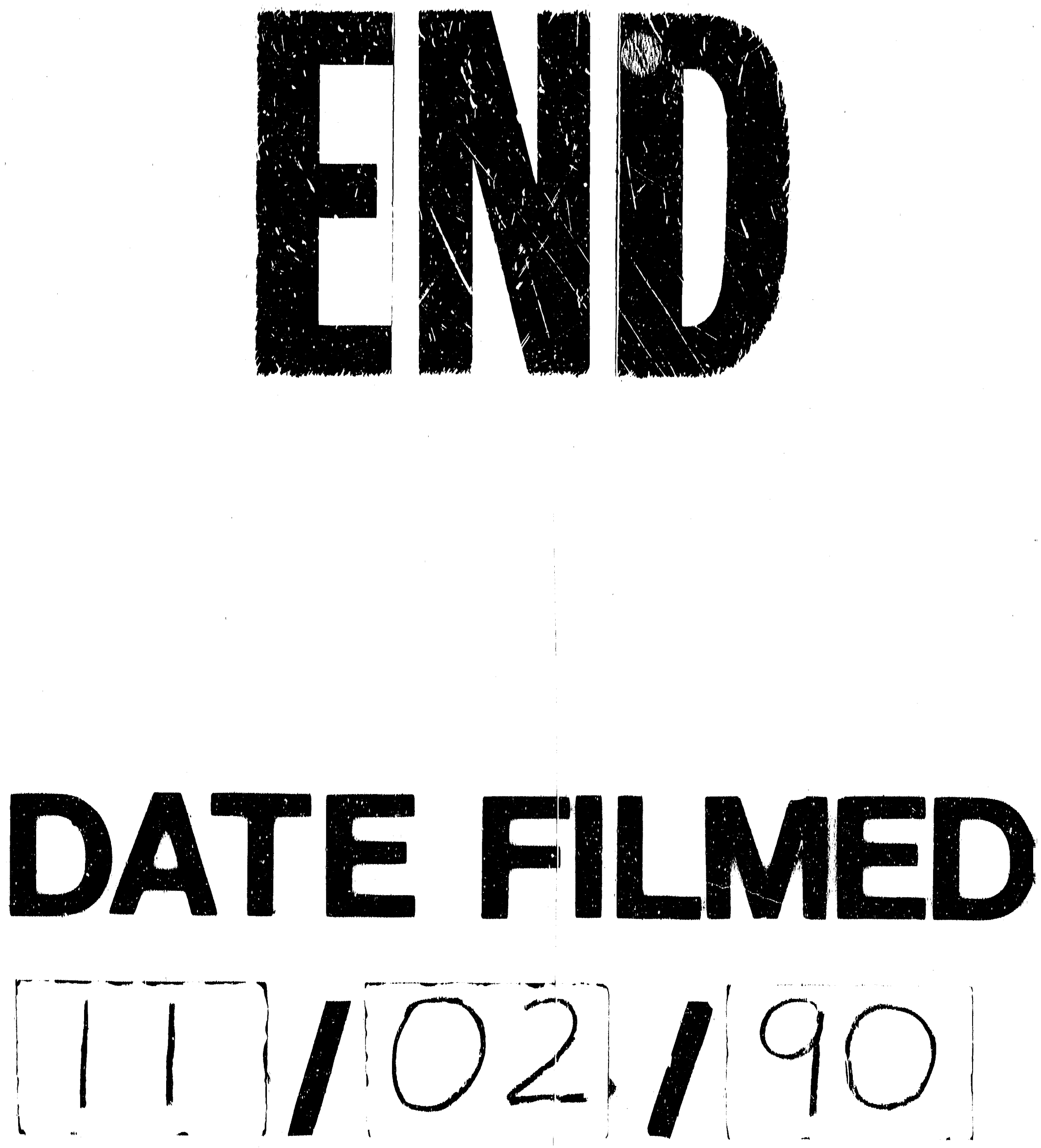
